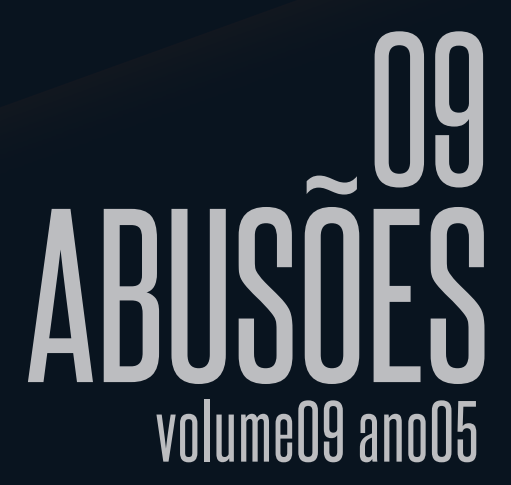




\section{SUMÁRIO}

EDITORIAL

APRESENTAÇÃO DO NÚMERO 05

A BESTA DENTRO DE CADA UM: METAMORFOSES DO VAMPIRO NA LITERATURA BRASILEIRA

DEU IMPRINTING!: VAMPIROS, LITERATURA BEST-SELLER E CONVERGÊNCIA DAS MÍDIAS A PARTIR DO FENÔMENO JUVENIL THE TWILIGHT SAGA 46

AMBIGUIDADES DO VAMPIRO NA LITERATURA OITOCENTISTA 75 JACQUES CHESSEX: O ESCRITOR-VAMPIRO DE ROPRAZ 114

MULHERES MONSTRUOSAS: O CTÔNICO E O SELVAGEM

EM CARMILLA, DE LE FANU 145

VAMPIRAS DO SERTÃO NO CONTO "AS MORFÉTICAS",

DE BERNARDO ÉLIS 166

O VAMPIRO COMO METÁFORA NA LITERATURA BRASILEIRA OITOCENTISTA

O FENÔMENO DO VAMPIRISMO: GIOSEPPE DAVANZATI E A INTRODUÇÃO DO VAMPIRO NA EUROPA OCIDENTAL (1739-1774)

VAMPIRISMO E CLAUSURA DO DESEJO EM O DESCONHECIDO E ANGÉLICA, DE LÚCIO CARDOSO

VAMPIRISMO E CLAUSURA DO DESEJO EM O DESCONHECIDO E ANGÉLICA, DE LÚCIO CARDOSO 
TWO HUNDRED FACES OF A VAMPIRE: LORD RUTHVEN'S INFLUENCE ON VAMPIRE CULTURE 305

ENTREVISTA COM A ESCRITORA GIULIA MOON 328

ENTREVISTA COM O EDITOR CID VALE FERREIRA 339

DÉCADENCE FIN DE SIÈCLE (2017), DE MICHEL WINOCK 353 


\section{EDITORIAL}

As artes da abusão: dos erros de percepção, das coisas que se tomam por outras, das ilusões e dos enganos; da crença no fantástico e das superstições; dos feitiços, dos esconjuros e dos malefícios. Foi em torno dessa hoje exótica palavra que nasceu a Abusões, revista dedicada às ficções que transitam nas franjas do real, um projeto que é fruto da parceria entre dois Grupos de Pesquisa certificados pela Universidade do Estado do Rio de Janeiro (UERJ) junto ao Diretório de Grupos do Conselho Nacional de Desenvolvimento Científico e Tecnológico (CNPq), o Nós do Insólito: Vertentes da Ficção, da Teoria e da Crítica e o Estudos do Gótico.

O vigor desse campo de estudos nas universidades brasileiras é atestado pelo surgimento e consolidação, nos últimos anos, de vários grupos de pesquisa a ele dedicados, como o Vertentes do Fantástico na Literatura (UNESP), o Espacialidades Artísticas (UFU), o Língua e literatura: interdisciplinaridade e docência (UNIFESP) e o Narrativa e insólito (UFU), todos reunidos, juntamente com nossos dois grupos da UERJ, no GT da Associação Nacional de Pós-graduações e Pesquisa em Letras e Linguística Vertentes do Insólito Ficcional.

Dessas inúmeras e labirínticas intersecções e tangências entre o insólito, o gótico, o fantástico, o medo, o estranho, o maravilhoso, o horror, a fantasia, o sobrenatural, vêm os artigos que dão corpo à publicação. Interessa veicular os resultados de pesquisas dessa vasta rede de estudos, seja como um instrumento de divulgação, seja como um ambiente crítico, capaz de integrar trabalhos individuais em projetos coletivos. 
Abusões é uma publicação semestral, hospedada no Portal de Publicações Eletrônicas da UERJ, e tem por finalidade a divulgação de artigos, resenhas, entrevistas e fontes documentais relevantes para os estudos do Gótico, do Fantástico e do Insólito. A revista publica textos em Português, Espanhol, Francês, Italiano, Inglês e Alemão, de autoria de pesquisadores e professores doutores ou doutorandos em coautoria com seus orientadores.

Editores Gerentes

Flavio García (UERJ) Líder do GP Nós do Insólito: Vertentes da Ficção, da Teoria e da Crítica Júlio França (UERJ) Líder do GP Estudos do Gótico 


\section{APRESENTAÇÃO}

Alexander Meireles da Silva (UFG-Catalão)

Fernando Monteiro de Barros (UERJ-FFP)

Júlio França (UERJ)

O ano de 2019 marca os dois séculos de existência do conto "The Vampyre", considerado o texto que inaugura a presença do vampiro na prosa de ficção ocidental. Seu autor, o inglês John Polidori (1795-1821), teria se baseado em um fragmento que o célebre poeta Lord Byron (1788-1824) escrevera na muito decantada noite de Junho de 1816 às margens do Lago Genebra, na Suíça, na companhia do poeta Percy Shelley (1792-1822) e de sua companheira, futura esposa, Mary Shelley (1797-1851). Ao ser publicado em Abril de 1819 na New Monthly Magazine o conto foi erroneamente atribuído a Byron, que, logo em seguida, publicou seu "Fragment of a novel" para desfazer o equívoco. Em todo caso, o bardo inglês parece ter servido de inspiração para Polidori, que constrói o seu vampiro - Lord Ruthven - à sua semelhança, em uma espécie de roman à clef, dentro da linhagem dos homens fatais românticos: belos, misteriosos, sinistros, cruéis e pertencentes à aristocracia. O vampiro das lendas do folclore da Europa Central era uma criatura feia, grotesca e repulsiva, que saía de sua tumba para sugar o sangue dos membros de sua própria família. Já o vampiro cunhado por Polidori inaugura o arquétipo sedutor e sexualizado que será uma das principais marcas deste personagem daí em diante, como atesta Drácula, seu representante mais notório. 
Volátil, entretanto, o personagem se desdobra em inúmeras metamorfoses, variações do mesmo tema, nas narrativas literárias, e posteriormente cinematográficas e televisivas, desde sua primeira aparição na segunda década do século XIX. Polissêmico e paradoxal, o vampiro desliza por várias metáforas e conjuga vários hibridismos. As fronteiras do sexo e da morte são por ele rompidas; é filho da modernidade, que assombra ao trazer em si as configurações arcaicas da natureza e da história; transita igualmente pela alta cultura e pela cultura de massa; pode comparecer ligado tanto ao sublime quanto ao grotesco; pode ser um dândi flâneur bem como um monstro enclausurado, e pode encarnar tanto a metáfora erótica quanto a metáfora política. Nesses duzentos anos da presença do vampiro na prosa de ficção ocidental, a revista Abusões, neste dossiê, apresenta artigos que tratam deste personagem em suas mais diversas configurações e aparições, seja na literatura, no cinema, nos quadrinhos, no cinema ou nos seriados televisivos e online.

Em "A besta dentro de cada um: metamorfoses do vampiro na literatura brasileira", Pedro Sasse aponta como o vampiro, no imaginário vitoriano horrorizado com as teorias de Darwin, tornase emblema de uma espécie de horror biológico, metaforizando a animalidade violenta dentro de cada ser humano - animalidade esta também representada pelo serial killer famoso da Londres finissecular: Jack, o Estripador. Esta mesma ansiedade relacionada ao criminoso sanguinário tem na literatura brasileira a sua corporificação na figura do predador urbano, presente em narrativas de João do Rio, Lúcio Cardoso e Dalton Trevisan, com vários signos que remetem ao caráter assassino do Conde Drácula. 
Jennifer da Silva Gramiani Celeste e Juliana Gervason Defilippo exploram o universo dos best-sellers de vampiros voltados para o público adolescente e sua adaptação para o cinema, remetendo à relação estreita do personagem com a cultura de massa (que vem desde a década de 1820 com o estrondoso sucesso comercial do conto de Polidori adaptado para o teatro por Charles Nodier, na França), e elegem a saga Crepúsculo como foco de seu artigo "Deu imprinting: vampiros, literatura best-seller e convergência das mídias a partir do fenômeno juvenil The Twilight Saga".

Em "Ambiguidades do vampiro na literatura oitocentista", Juliana de Souza Topan argumenta que os traços de humanidade que têm sido constantes nas representações do vampiro desde o romance de Anne Rice de 1976 - e que, segundo David Roas, vêm acarretando em um processo crescente de domesticação do monstro - já podiam ser identificados em textos do século XIX sobre o personagem, como a balada "Christabel", de Samuel Taylor Coleridge, e a novela Carmilla, de Sheridan Le Fanu.

Questões do âmbito da estética pós-moderna são abordadas em "Jacques Chessex: o escritor-vampiro de Ropraz", artigo no qual Ana Amélia Gonçalves da Costa explora as relações entre ficção e realidade, a partir da figura do vampiro como metáfora do resgate da história através da ironia e da paródia.

Marina Pereira Penteado propõe em "Mulheres monstruosas: o ctônico e o selvagem em Carmilla, de Le Fanu" uma investigação acerca das representações sombrias e demoníacas do feminino, em sua imemorial identificação com a violência da natureza. A vampira da novela de Sheridan Le Fanu é tão mais aterrorizante por sua 
homossexualidade, assim também como na balada "Christabel", de Samuel Taylor Coleridge.

Fabianna Simão Bellizzi Carneiro traz o mito do vampiro para a literatura brasileira no artigo "Vampiras do sertão no conto 'As morféticas', de Bernardo Élis, através da ligação deste personagem com a morte e com o arquétipo do feminino cruel. $\mathrm{O}$ artigo explora as relações do mito com o grotesco e demonstra como tal mito se espraia muito além do contexto europeu original.

Ana Paula Araújo dos Santos explora o potencial simbólico do personagem do vampiro, ausente de forma literal na produção literária brasileira do século XIX, no artigo "O vampiro como metáfora na literatura brasileira oitocentista", no qual a autora discorre sobre como, em tal contexto, o vampiro acaba por representar morte, doenças e maldades. Os contos "A esteireira", de Afonso Arinos, e "Noites brancas", de Gastão Cruls, bem como o romance $A$ mortalha de Alzira, de Aluísio Azevedo, constituem o corpus de análise do artigo.

A disseminação da palavra vampiro na Europa, a partir dos relatos do padre italiano Gioseppe Davanzati redigidos em 1739 é o mote do artigo "O fenômeno do vampirismo: Gioseppe Davanzati e a introdução do vampiro na Europa ocidental (17391774)", no qual o autor, Gabriel Elysio Maia Braga, explora o famoso "surto" de vampirismo que pareceu assolar a Europa oriental em meados do Século das Luzes, veiculado por notícias de viajantes ocidentais na região, que deram origem não só ao estudo do padre Davazanti como também ao célebre tratado do monge beneditino Calmet, de 1751. 
O vampiro enquanto metáfora erótica do desejo enclausurado e interditado é o tema do artigo de Fernando Monteiro de Barros e Leonardo Ramos Botelho Gomes, "Vampirismo e clausura do desejo em O desconhecido e Angélica, de Lúcio Cardoso", que também atesta a presença da dimensão simbólica do mito na literatura brasileira.

"'Let them dream of life eternal, we shall live it': George R. R. Martin's Fevre dream, slavery and vampires in the United States of America", de Arthur Maia Baby Gomes e Cláudio Vescia Zanini, aborda o tema do vampirismo usado como crítica social em relação ao período escravocrata no sul dos Estados Unidos, dentro da tendência pós-moderna do romance histórico, que, aqui, conjugado ao pendor pelo simulacro desta tendência, é apresentado com forte presença do horror gótico.

"Two-hundred faces of a vampire: Lord Ruthven's influence on vampire culture", de Alexander Meireles da Silva e Francisco Javier Sánchez-Verdejo Pérez, presta tributo à efeméride deste dossiê, os duzentos anos da publicação de The Vampyre, de John Polidori, e sua vasta descendência literária ao longo dos séculos XIX e XX.

Além dos artigos de temáticas e abordagens variadas, o dossiê traz ainda duas entrevistas. A primeira da escritora Giulia Moon, criadora da vampira japonesa Kaori, da trilogia homônima - Kaori: Perfume de Vampira (Giz Editorial, 2009), Kaori 2: Coração de Vampira (Giz Editorial, 2011) e Kaori e o Samurai Sem Braço (2012). Moon é um dos principais nomes da literatura nacional de vampiros, e, na entrevista, ela fala sobre os desafios de se trabalhar com a tradição do vampiro no contexto do século vinte e um, entre outros temas. A segunda entrevista é com o livreiro e editor Cid 
Vale Ferreira, organizador de uma obra seminal para os estudos de literatura vampírica no Brasil, Voivode: Estudos sobre os vampiros (2003). Atualmente à frente da Clepsidra, uma editora independente focada na publicação de obras clássicas do Gótico, do Romantismo e da Decadência, Cid respondeu a perguntas sobre a importância do texto de Polidori e sobre seus novos projetos editoriais, como o lançamento da tradução do folhetim Varney, the Vampire.

Estamos convencidos de que os artigos que compõem o dossiê desse nono número da Revista Abusões reafirmam a perenidade e a difusão do vampiro na arte, uma personagem que, por séculos, erra pelas fronteiras entre a ficção e o mito, e que parece ser incessantemente capaz de encarnar, em suas múltiplas figurações ao longo da história, um amplo espectro de desejos e ansiedades do ser humano. 


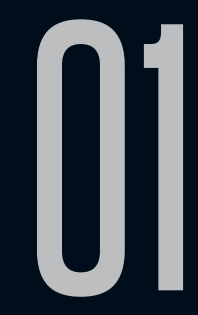

\section{A BESTA DENTRO DE CADA UM: METAMORFOSES DO VAMPIRO NA LITERATURA BRASILEIRA}

Pedro Sasse (UFF)

Recebido em 11 mar 2019. Aprovado em 24 mai 2019.
Pedro Sasse é Doutorando em Estudos Literários pela UFF e professor substituto de Teoria Literária e Literatura Brasileira da Faculdade de Formação de Professores da UERJ. É integrante do grupo de pesquisa "Escritos Suspeitos: estudos sobre a ficção criminal contemporânea", coordenado pela prof.a Carla de Figueiredo Portilho. Lattes: http://lattes. cnpq.br/7219234746540444.E-mail: pedro_sasse@ hotmail.com.

Resumo: A publicação da primeira edição de Drácula sucede apenas em alguns anos os famosos assassinatos de Whitechapel, que marcam a ação de um dos primeiros e mais famosos serial killers do mundo, Jack, o estripador. Assim como Jack, o vampiro de Bram Stoker ameaça Londres não apenas fisicamente, mas ontologicamente: ainda que não seja um amaldiçoado morto-vivo, Jack é a confirmação de uma ansiedade crescente que Darwin, entre outros, instaurou na sociedade oitocentista, a de que o homem, longe de ser uma criação especial de Deus, era apenas um animal entre outros. Esse homem cujo interior guarda uma besta sedenta por sangue, representado pela literatura vitoriana de vampiros, encontrará seu espelho realista nos assassinos da literatura de crimes que floresce na mesma época, sem dúvida inflamada por casos como os horrendos crimes de Whitechapel. 
Enquanto o Brasil não se mostra um país pródigo em representações do vampiro propriamente dito, é rico em narrativas que abordam os mesmos medos inspirados por esse predador urbano, chegando, muitas vezes, a incorporar em suas figuras reais traços desses monstros sobrenaturais. Propomos, assim, uma leitura dos predadores urbanos brasileiros à luz dos medos da animalização do homem levantados pela literatura vitoriana, mostrando uma das metamorfoses possíveis do vampiro em território nacional.

Palavras-chave: Cidade; Monstro; Ciência; Medo; Vampiro.

Abstract: The publication of Bram Stoker's Dracula, in 1897, goes just a few years after the Whitechapel murders which have singled out the acts of the most infamous worldwide well-known serial killer, Jack, the Ripper. Similar to Jack, Bram Stoker's vampire threatens London not only physically, but also ontologically: even though Jack is not a cursed undead, he corroborates a growing anxiety which Darwin, amongst others, has introduced in the nineteen-century society, that is, that humans, far from being God's special creation, were merely animals among other animals. This human, who keeps a bloodthirsty beast inside which is represented by the Victorian vampire literature, will be found mirrored by crime literature killers which flourish at the same period, undoubtedly influenced by cases such as the Whitechapel's hideous crimes. Whereas Brazil is not well-known for depicting a more traditional vampire figure, it has nonetheless a myriad of narratives which approach the same fears inspired by this urban predator - one, many times, incorporating typical traces of these supernatural monsters. Hence, we aim at shedding some light upon these Brazilian urban predators based on the fears of animalization brought to life by the Victorian literature, opening the path to one possibility of vampire metamorphosis in our country.

Keywords: City; Monster; Science; Fear; Vampire. 
Drácula, de Bram Stoker, é publicado por primeira vez em 1897. Na mesma época, inúmeros livros e jornais vendiam as histórias escabrosas de Jack, o estripador, como vemos em Chronicles of Crime and Criminals, publicado pela Beaver Publishing em 1895. Perigos de natureza muito distintas, um plenamente ficcional - ainda que vejamos o uso de paratextos que tentem mascarar essa ficcionalidade -, o outro baseado em uma ameaça própria do mundo real. No entanto, como pretendemos demonstrar aqui, Jack e Drácula tem, entre si, mais semelhanças que diferenças, sendo duas manifestações metafisicamente distintas de um mesmo conjunto de ansiedades de seu contexto de produção.

Ainda que tal hipótese nos ajude a enxergar os processos de construção dos monstros na ficção e fora dela, nosso objetivo aqui se inclina para uma investigação não sobre a literatura de medo estrangeira, mas a nacional. A partir de tal paralelo, buscar-se-á demonstrar como a literatura de medo brasileira, influenciada por uma crítica que privilegiava o documental e o realismo às literaturas de cunho mais imaginativo (FRANÇA, 2017, p.27), encontrará nos suspenses psicológicos ${ }^{1}$ uma forma não apenas de lidar com as mesmas ansiedades envolvidas na literatura de vampiros, como utilizará com certa frequência de metáforas, símbolos e alusões a esse monstro na construção de suas narrativas de medo não sobrenatural.

1 Chamamos aqui de suspense psicológico o que a crítica anglófona de ficção de crime denominará Psycho Thriller (SIMPSON, 2010, p.187), subgênero do suspense centrado na representação de crimes como manifestações externas dos processos psicológicos (ou psicopatológicos) de uma mente transtornada. 


\section{MONSTROS CULTURAIS}

Jeffrey Jerome Cohen (2000), em “A cultura dos monstros: sete teses" trabalha com a ideia de que o corpo do monstro é um corpo cultural, ou seja:

O monstro nasce nessas encruzilhadas metafóricas, como a corporificação de um certo momento cultural - de uma época, de um sentimento e de um lugar. O corpo do monstro incorpora - de modo bastante literal - medo, desejo, ansiedade e fantasia (ataráxica ou incendiária), dando-Ihes uma vida e uma estranha independência (p.27)

Cohen afirma, com isso, que a existência dos monstros em uma determinada época está diretamente conectada ao momento cultural da sociedade que os engendra. Medos, fantasias e desejos não só servem de inspiração para o surgimento de tais criaturas, como são elementos impressos em sua própria morfologia, permitindo que, ao fazer o caminho reverso, o crítico seja capaz de desvendar no corpo desses monstros signos sobre a cultura que os formulou.

Através dessa perspectiva, seria possível ler, no corpo do vampiro - a limiaridade ontológica, as presas, o dom proteico medos próprios da sociedade vitoriana. Tal trabalho é empreendido com maestria por Jason Colavito (2008) em Knowing Fear: Science, Knowledge and the Development of the Horror Genre. Colavito restringe um pouco o processo de análise proposto por Cohen, focando-se, sobretudo, nos medos inspirados pelo avanço das ciências e outras formas de produção de conhecimento. O vampiro e, como veremos, também os assassinos seriais -, se enquadrariam, assim, no que Colavito chamará de Biological horror. 
Para Colavito, tanto Drácula, como a criatura de Frankenstein ou Mr. Hyde, monstros eternizados no horror, apontam para um tema central: o conflito entre a natureza humana e a natureza animal, a limiaridade entre o homem e a besta que o habita. Se, hoje, para nós, a visão do homem como um animal pouco apresenta de atemorizante, é preciso lembrar que até o século XIX - sobretudo, até a popularização da visão darwinista do homem - o ser humano apresentava um lugar de destaque na hierarquia da vida no planeta. Remontando a era clássica, a ideia da Grande Cadeia dos Seres (Great Chain of Being), já presente em Platão e Aristóteles, vê o homem como o pináculo de um longo processo evolutivo linear que começa nas criaturas mais simples e, degrau por degrau, incrementa sua complexidade até chegar ao ser humano (COLAVITO, 2008, p.66).

Essa centralidade do homem começa a perder força a partir do iluminismo e continua decaindo ao longo dos Oitocentos, mas é apenas em Darwin que sofrerá o golpe cujos ecos se encontrarão na literatura vitoriana de horror:

Mas importante, e mais devastador, Darwin pela primeira vez divorciou a evolução da velha ideia de progresso, quebrando a Grande Cadeia dos Seres. Na nova evolução, não havia "alto" ou "baixo" ou um progresso inexorável até a divina "perfeição". Em vez disso, havia apenas "mudança". Isso perturbou às mentes do século XIX mais do que qualquer outro aspecto da teoria evolucionária, porque, de golpe, divorciou a humanidade da criação especial de Deus e reduziu, mesmo que apenas por implicação, humanos a apenas outro em muitos animais, sem ao menos ter direito ao 
título de mais alto entre os seres ${ }^{2}$ (COLAVITO, 2008, p.68 - tradução nossa)

Destituídos de qualquer lugar especial na ordem cósmica, o homem é igualado aos demais animais e sua consequente natureza animalesca se torna um aspecto a ser temido. Desse trauma para a sociedade ocidental surgiria, segundo Colavito, o principal elemento necessário para a ascensão do Biological Horror, centrado no medo do lado selvagem da humanidade, na besta escondida dentro de cada um.

Retomando Cohen, esse temor se manifesta morfologicamente no vampiro. Por um lado, o vampiro é tão humano que é capaz de misturar-se aos mortais sem ser notado por aqueles sem a sensibilidade para ver através de sua superfície. Por outro, sua natureza animalesca surge através de suas presas, de sua capacidade de metamorfosear-se em animais e de sua sede por sangue. A mesma dualidade é encontrada em $O$ médico e o monstro, em que Dr. Jekyll representa o humano e Hyde o bestial, e em Frankenstein, em que a criatura, feita a partir de partes humanas, carece dos freios civilizatórios necessários para impedir os assassinatos que comete.

Essa visão, no entanto, impacta também a perspectiva da sociedade sobre o crime. Segundo John Cawelti (1975), em "The New Mithology of Crime", o século XIX apresenta uma mudança na produção da literatura de crime que a afasta do modelo moralpedagógico dos textos do século XVIII:

2 No original: "More importantly, and more devastatingly, Darwin for the first time divorced evolution from the old idea of progress, breaking the Great Chain of Being. In the new evolution there was no "higher" or "lower" or inexorable progress toward divine "perfection." Instead, there was only "change." This disturbed nineteenth century minds more than any other aspect of evolutionary theory, for at a stroke it divorced humanity from God's special creation and it reduced, if only by implication, humans to merely one among many animals, not even worthy of the title of the highest being". 
Um terceiro fator central nas atitudes em relação ao crime no século XIX foi a ascensão de uma abordagem científica e social da análise dos atos criminais, o que levou à investigações empíricas e à suposição de que o crime seria melhor compreendido e tratado não como uma questão moral ou religiosa, mas em termos de seu contexto social e psicológico ${ }^{3}$ (p.330 - tradução nossa)

Do lado positivo, essa mudança colaborou para uma literatura de crime mais crítica em relação à sociedade e às instituições responsáveis pela manutenção da ordem. Por outro, divorciando o crime de suas influências religiosas, tornou o homem o único culpado possível para os mais horrendos atos. Unindo-se a essa visão, a popularização dos assassinos seriais através de Jack, o estripador, em Londres, e H. H. Holmes, nos EUA, vemos esse novo criminoso como a hipérbole da animalização do homem:

Os assassinos no fin de siècle pareciam servir perfeitamente para confirmar a teoria de Darwin de que os homens eram meros animais, presos unicamente ao natural instinto de morrer ou ser mortos $^{4}$ (COLAVITO, 2008, p.77 - tradução nossa)

Uma segunda tese levantada por Cohen é a de que "O monstro sempre escapa". Tal tese tem a difícil tarefa de dar conta de um sério problema para a própria proposta criada pelo autor: se o monstro é um corpo cultural em que se inscrevem as ansiedades

3 No original: "A third major factor in nineteenth century attitudes toward crime was the rise of a scientific and social approach to the analysis of criminal deeds, which led to empirical investigations of the causes of crime and to the assumption that crime could be best understood and dealt with not as a moral or religious matter but in terms of its social or physiological background".

4 No original: "The murders in the fin d. Hick seemed tailor-made to confirm Darwin's theory that humans were merely animals, beholden only to the natural instinct to kill or be killed". 
de um determinado momento cultural, a mudança de momento cultural deveria ter como consequência a mudança também nos monstros concebidos pelas gerações seguintes. No entanto, o que vemos de forma clara na história do horror é uma recorrência de certos monstros arquetípicos, dentre os quais o vampiro assume posição central:

Ao falar do novo tipo de vampiro inventado por Bram Stoker, podemos explorar a sexualidade transgressiva mas irresistível do estrangeiro conde como sutilmente atraente para Jonathan Harker da mesma forma que Henry Irving, o mentor de Stoker, o era para Stoker. Ou podemos analisar a apropriação autodepreciativa que Murnau faz do mesmo demônio em Nosferatu, no qual, diante do nascente fascismo, os elementos subterrâneos do desejo sobem à superfície por meio da praga e da degradação corporal. Anne Rice deu ao mito uma reescrita moderna, na qual a homossexualidade e o vampirismo foram reunidos de forma apoteótica; 0 fato de que ela criou, nesse processo, um fenômeno de cultura pop não é algo sem importância, especialmente em uma época na qual o gênero, visto como um constructo, tem sido questionado em quase todo registro social. No recente sucesso de bilheteria do filme Bram Stoker's Dracula, de Francis Coppola, o subtexto homossexual presente desde a aparição da lésbica Laura, de Sheridan Le Fanu (Carmilla, 1872), tal como os corpúsculos vermelhos que servem como o leitmotif do filme, sobe à superfície, primariamente como consciência da AIDS, transformando a doença do vampirismo em uma forma sádica (e muito medieval) de redenção por meio dos tormentos do corpo que sofre. Nenhuma coincidência, pois, que Coppola estivesse produzindo um documentário sobre 
a AIDS ao mesmo tempo em que ele estava trabalhando no Drácula (COHEN, 2000, p.28-29)

Podemos dividir, a partir dessa perspectiva, a constituição do monstro em dois eixos: de um lado, temos o monstro enquanto forma, referencial imagético mais ou menos cristalizado na mente dos leitores, carregando não apenas a corporificação das ansiedades de sua época, mas também as cicatrizes de sua apropriação ao longo do tempo, a história de sua própria recepção e ressignificação. Do outro, temos o monstro enquanto conteúdo, a constelação de temas, fantasias, medos e desejos inspirados por esse monstro. Esse conteúdo, por um lado, pode se manifestar em diversos corpos monstruosos de uma determinada época - sendo o que permite que Colavito costure Drácula, Hyde, Frankenstein e Jack, o estripador, no horror biológico -, e, por outro, pode encontrar novos corpos monstruosos em diferentes épocas ou lugares que compartilham de ansiedades semelhantes.

Esse vampiro enquanto forma, imagem, que antecede inclusive suas manifestações vitorianas, remontando ao folclore medieval na Europa, é apropriado enquanto símbolo já consolidado no gênero do horror e ressignificado para se adequar a diversos conteúdos, do homoerotismo de Carmilla aos conflitos juvenis da saga Twilight. Pensando, no entanto, no conteúdo cultural lido nesse vampiro vitoriano, vemos que os mesmos medos podem manifestar-se em outras figuras monstruosas, não necessariamente sobrenaturais. Enquanto as apropriações mais recentes do vampiro, como o hollywoodiano Dracula untold (2014), de Gary Shore, ressignificam de tal forma o conteúdo do monstro que o afastam inclusive do gênero de horror, vemos em obras como $O$ silêncio dos inocentes, de Thomas 
Harris, uma obra de medo não sobrenatural que tem muito mais a dizer sobre os medos inspirados pelo vampiro vitoriano que diversas leituras contemporâneas do vampiro de fato. Dr. Hannibal Lecter revive cada aspecto do Drácula de Stoker: desde o comportamento aristocrático à sede de sangue, da natureza animalizada à capacidade hipnótica, apontando para os horrores dessa besta sedenta por sangue que residiria no interior de cada homem.

Retomamos, assim, a hipótese de que o vampiro vitoriano encontra no conteúdo cultural de sua monstruosidade os mesmos elementos explorados pelas narrativas de Jack, o estripador, e, posteriormente, H. H. Holmes. Podemos destacar, na análise de Colavito sobre Drácula - amparada por uma leitura de seus predecedores oitocentistas, The Vampyre, de Polidori, Varney, the Vampire, de Rhymer e o já citado Carmilla - alguns temores compartilhados entre a literatura centrada em vampiros e psicopatas: o já comentado medo da besta interior, da natureza do homem e sua capacidade de subjugar seu lado racional e moral; o medo de tornar-se a vítima desse animal-homem - temor, alimentado pelo aumento da criminalidade e da exposição midiática dessa criminalidade nos grandes centros urbanos; e, por último, um medo de cunho sexual, indissociável da nova percepção da natureza selvagem do homem, mas também alimentado pelas ansiedades vitorianas sobre as mudanças na forma como o sexo era encarado na sociedade, sobretudo em relação às mulheres.

Já vemos no pioneiro vampiro de Polidori a presença da dualidade animalesca representada pelo vampiro. Em Polidori, no entanto, esse medo se concentra, sobretudo, no homem enquanto vítima desse predador capaz de se misturar entre os demais mortais. Essa 
animalização do homem que se consolida na literatura vitoriana encontra seu germe no século anterior tendo Sade como portavoz. Nas obras do autor francês, vemos, através do discurso dos burgueses e aristocratas, vemos como a aceitação da natureza animal do homem serve como libertação da moral cristã e justifica a consumação dos mais cruéis atos. Em Justine, por exemplo, veremos o marquês de Bressac legitimar o assassinato da mulher que o criou levando a ideia da perda do lugar privilegiado do homem na natureza que começava, então, a se formar nas ciências ocidentais:

- O que importa para a natureza sempre criadora aquela massa de carne que hoje tem a forma de uma mulher se reproduza amanhã sob a forma de mil insetos diferentes? Ousarás dizer que a construção de um indivíduo como nós custa mais à natureza que a de um verme e que, por conseguinte, ela deva dar-Ihe mais atenção? Ora, se o grau de atenção ou melhor, de indiferença, é o mesmo, que pode ela fazer, senão pelo que chamamos de crime de um homem, que um outro seja transformado em mosca ou em escarola? Quando me tiverem provado a sublimidade de nossa espécie, quando me tiverem demonstrado que ela é tão importante para a natureza que necessariamente suas leis se irritam com sua destruição, então eu poderei crer que essa destruição é um crime; mas quando o estudo mais ponderado da natureza me tiver provado que tudo o que vegeta sobre o globo, a mais imperfeita das suas obras, tem um preço igual aos seus olhos, jamais suporei que a mudança de um de seus seres em mil outros possa ofender suas leis; eu me direi: todos os homens, todas as plantas, todos os animais que crescem, vegetam, se destroem pelos mesmos meios, não recebendo jamais uma morte real, mas uma simples variação 
no que as modifica, tudo, digo, tudo se perseguindo, destruindo-se, procriando indiferentemente, aparece um instante sob uma forma e no instante seguinte sob uma outra, podem ao capricho do ser que quer ou que pode move-los, mudar milhares e milhares de vezes num dia sem que uma única lei da natureza possa ser afetada por instantes sequer (SADE, 1979, p.39)

Em uma literatura constringida pela moral vitoriana, no entanto, os monstros libertos de Sade não encontrariam espaço. É preciso, então, que essa animalização, mais que uma total entrega aos instintos - ainda que racionalizados em Sade - seja tensionada com o lado consciente, racional e, sobretudo, moral. Varney, no romance de Rhymer, já expressa a angústia de sua condição, adicionando à ameaça externa representada por essa natureza animal do homem outra interna, a de que nós mesmos sejamos tomados por tal condição, nos tornemos o monstro:

É seu sofrimento mental e sua inabilidade para alinhar sua moralidade com sua fome animal fundamental que o define, e o destrói. Ele é a besta, suspensa entre o mundo animal e o mundo humano $^{5}$ (COLAVITO, 2008, p.85 - tradução nossa)

Em Drácula, ainda que o dilema moral não apareça tão latente, vemos as amarras morais cerceando o monstro através da eficácia da religião contra a criatura. Dessa forma, a animalização do homem pode e é controlada através de uma instância superior, apontando para um resguardo para o homem diante da violência predatória da natureza.

5 No original: "It is his mental anguish and his inability to rectify his morality with his base, animal hungers that define him, and destroy him. He is a beast, suspended between the animal world and the human". 
Colavito ressalta como a mais explícita metáfora da condição animalizada do homem no vampiro é a presença dos caninos que surge em Varney. Símbolo do animal predatório, oposto à civilidade humana, o canino é o instrumento que servirá para saciar o desejo incontrolável do homem pelo sangue, pela vida de suas presas. Contudo, junto a essa analogia, Colavito mostra como, em muitas leituras, outro desejo predatório humano é também simbolizado pelos caninos: o sexual. Em Drácula, abundam interpretações psicanalíticas da relação entre o ataque do vampiro e o ato sexual:

Provavelmente, em toda a literatura de horror, nenhum outro livro reuniu tal volume de interpretações psicossexuais. (...) A maior parte dos críticos (...) concorda que as presas do vampiro representam o pênis, que sua mordida é uma agressão oral do sexo genital normal e que o romance lida primariamente com as ansiedades vitorianas sobre mudanças de papeis sexuais e a repressão dos desejos sexuais ${ }^{6}$ (2008, p.88 tradução nossa)

Enquanto Varney e Drácula representam o ataque predatório sexual masculino, Carmilla, assim como as asseclas de Drácula, corporifica as ansiedades sobre a progressiva emancipação da mulher e o domínio de sua própria sexualidade, unindo a isso, claro, o homoerotismo na obra de LeFannu. A femme fatalle, arquétipo recorrente na literatura finissecular, encontrará na figura do vampiro uma de suas mais recorrentes manifestações ao longo do tempo.

6 No original: "Probably in all horror literature, no other book has garnered such a volume of psychosexual interpretation. (...) Most critics (...) agreed that the vampire's fangs represent the penis, that his bite is an oral aggression of normal genital sex, and that the novel deals primarily with the Victorian anxiety about changing sex roles and the repression of sexual desire". 
Se olharmos, agora, para as narrativas de psicopatas que começam a se desenvolver nessa época, perceberemos que o conteúdo aterrorizante encontrado nessas histórias encontrará fortes paralelos com aqueles próprios da literatura vitoriana de vampiros. Clive Bloom (2017), em "Dracula and the Psychic World of the East End of London", defende mais do que um conteúdo semelhante, apontando que haveria conexões diretas entre o vampiro construído por Stoker e a figura de Jack, o estripador.

Bloom parte, para sua pesquisa, de uma dúvida central: por que, havendo tão claras semelhanças entre a história de Drácula os crimes de Jack, não há nenhuma menção explícita ao assassino no romance de Stoker?

Para defender a ideia de que, de fato, havia tal semelhança, Bloom mostra como, não só a mídia da época construía uma imagem de Jack que se assemelhava ao monstro arquitetado por Stoker, como também, em um dos primeiros romances sobre o assassino, The True History of Jack The Ripper [1905], de Guy Logan, há claras referências ao vampiro. A narrativa de Logan é centrada na figura do Dr. Mortemer Slade e sua escapada de um manicômio em 1887. Slade sofria de uma peculiar insanidade moral, que não afetava em nada sua razão - apontando já para o perfil dos psicopatas que se consolidarão na literatura décadas mais tarde com $O$ assassino em mim, de Jim Thompson, e O talentoso Ripley, de Patrícia Highsmith -, permitindo-o camuflar-se entre os demais sem dificuldades, sendo entregue apenas por seu sorriso, descrito pelo autor como "not a nice smile. His lips were thin, his teeth rather sharp and discoloured" (Logan, Apud BLOOM, 2017, p.120). Bloom parte dessa clara referência para mostrar outras semelhanças entre os personagens: 
Slade acredita que "todo homem é louco, mas alguns são mais loucos que outros". Assim como Drácula, ele também circula disfarçado "[assumindo] com o propósito de disfarce uma barba falsa e um bigode". Sua senhoria acredita que ele é um "nobre refugiado da Roosia [sic]" e, como $\mathrm{O}$ estripador, ele escreve suas letras com "sangue humano líquido", mas para fazer a conexão mais clara, somos informados que "seus lábios eram finos, seus dentes afiados e descoloridos". Suas caças estão em Whitechapel, ele tem olhos hipnóticos e ele se delicia no "êxtase de matar", sinalizando-se como Jack o estripador. Como detalhe, adiciona-se o fato de que Slade tem uma "alma como as de ghoul", confirmando suas credenciais góticas ${ }^{7}$ (p.120 - tradução nossa)

O objeto central de análise de Bloom, no entanto, é uma versão islandesa de Drácula editada por Valdimar Ásmundsson que, retraduzida ao inglês há poucos anos, revelou uma narrativa bem distinta de sua versão original. Sem poder precisar se a versão de Valdimar foi de fato autorizada pelo próprio Stoker ou se é fruto de uma alteração radical feita pelo próprio jornalista islandês, Bloom vê a obra como um possível indício de que, se o Drácula original não parece associar-se diretamente ao caso de Jack, tal associação era existente no imaginário popular - tanto que foi realizada na versão de Ásmundsson.

Já no prefácio de Powers of Darkness [Makt Myrkranna], nome que recebeu a versão islandesa, podemos notar a clara aproximação 7 No original: "Slade believes "all men are mad, but that some are more mad than others". Like Dracula he too goes around in disguise "[assuming] for the purpose of concealment a false beard and moustache". His landlady believes him to be a "refugee nobleman from Roosia [sic]" and like the Ripper he writes his letters in "liquid human blood", but to make the connection clearer, we are told that "his lips were thin, his teeth rather sharp and discoloured". His prey is in Whitechapel, he has hypnotic eyes and he revels in "the ecstasy of killing" signing himself Jack the Ripper. To add to the detail Slade has a "ghoul like soul" confirming his gothic credentials". 
com Jack o estripador. Nesse prefácio, o autor teria recorrido a uma estratégia semelhante àquela usada por Walpole em $O$ castelo de Otranto, apresentando a obra como uma narrativa ancorada na realidade. Para tal, utilizaria como ponto de contato justamente os crimes de Whitechapel:

Eu enfatizo novamente que a misteriosa tragédia descrita aqui é completamente verdadeira em todos os seus aspectos externos... essa série de crimes, que parecem incompreensíveis mas parecem derivar da mesma raiz - e criaram em seu tempo tanto horror no público quanto os infames assassinatos de Jack o estripador [alternativamente na nova tradução: Jacob the Disemboweller], que ocorreram pouco tempo depois ${ }^{8}$ (Bram Stoker/ Valdimar Ásmundsson, Apud BLOOM, 2017, p.122-123 - tradução nossa)

A narrativa em si também é drasticamente alterada, havendo mudança não só de nomes de personagens, como localidades da obra, redução drástica dos diálogos e dissolução da forma epistolar em prol de um narrador onisciente. Se, por um lado, tais alterações, como o nome dos personagens, visam a adaptar a obra à realidade de leitores da Islândia, outras alterações poderiam indicar uma aproximação entre Drácula e as narrativas mais populares, como os penny dreadful que circulavam na Inglaterra desde meados do século XIX.

Em alguns diálogos da obra, podemos ver novos rastros da conexão entre os dois personagens. Ainda na primeira parte, em que Harker se encontra no castelo do conde, o vampiro se interessa

8 No original: "I emphasize again that the mysterious tragedy described here is completely true in all its external aspects... this series of crimes, which see incomprehensible but appear to stem from the same root - and have created in their time as much horror within the public as the infamous murders by Jack the Ripper [alternatively in the new translation: Jacob the Disemboweller], which occurred a short time later". 
por Londres, ficando profundamente entusiasmado ao ouvir a menção aos assassinatos de Whitechapel:

"Sim," o conde disse, sem fôlego e com entusiasmo... "Sim, esses crimes, esses horríveis assassinatos; aquelas mulheres massacradas encontradas em sacos, boiando no Tâmisa; o sangue que corre - corre e flui - sem que nenhum assassino seja encontrado." ... ele parecia estar lambendo os lábios com desejo... "Sim, é uma tragédia," ele disse, "e esses assassinados nunca serão desvendados - jamais. Seu escritor, Conan Doyle, escreveu diversos bons livros sobre Londres... De acordo com eles, apenas dois ou três por cento de todos os casos de homicídio são resolvidos. Sim, Londres é de fato uma cidade notável ${ }^{9}$ (BRAM STOKER/ VALDIMAR ÁSMUNDSSON, Apud BLOOM, 2017, p.126 - tradução nossa)

A estratégia de Ásmundsson de aproveitar-se do clima de medo transmitido na realidade pela figura de Jack para alimentar os horrores da ficção de que traduzia e adaptava nos confirma a proximidade existente entre os medos projetados pelos psicopatas e vampiros nessa virada para o século $X X$.

Dessa forma, vemos que não há uma questão simples de fonte e influência envolvida na questão entre a literatura de vampiro e a literatura de crime vitoriana, mas um diálogo em que as obras de psicopatas beberão do legado deixado por Drácula e outras histórias desse horror biológico - sobretudo no conflito da besta interior 9 No original: '“Yes,' the Count said, breathless with excitement...'Yes, these crimes, these horrible murders; those slaughtered women found in sacks, drifting in the Thames; this blood that runs - runs and flows - with no killer to be found.'...he seemed to be licking his lips with lust...'Yes, it is a tragedy' he said, 'and these murders will never be solved - ever. Your writer, Conan Doyle, has written many good books about London... According to them, barely two or three percent of all homicide cases are solved. Yes, London is indeed a remarkable city."' 
enquanto essas histórias sobrenaturais utilizarão os medos urbanos como forma de intensificar seus próprios efeitos estéticos.

Frutos de um mesmo momento sociocultural, os primeiros psicopatas da literatura e os monstros sobrenaturais vitorianos, sobretudo o vampiro, podem mudar seus símbolos, mas apontam para um mesmo fundo comum de medos próprios de sua realidade, alguns dos quais se perpetuarão até a contemporaneidade.

Tendo sido possível demonstrar, através dessa leitura do horror biológico de Colavito e da monstruosidade cultural de Cohen, que podemos estreitar as relações entre o monstro sobrenatural e o monstro humano - e para ser mais específico, entre o vampiro nos moldes vitorianos e esse assassino psicopata que surge no mesmo momento -, propõe-se, então, que esse monstro humano, por encontrar mais espaço e aceitação na crítica e na recepção da literatura brasileira, servirá não apenas para corporificar as ansiedades relacionadas ao lado animalizado do homem, como, ainda, para dialogar diretamente com a tradução da literatura de vampiros, ao utilizar metáforas, símbolos e outras alusões a esse personagem já consolidado no imaginário popular.

\section{METAMORFOSES DO VAMPIRO NO BRASIL}

Ainda que recentemente grupos de pesquisa especializados na literatura do medo e do fantástico venham descobrindo cada vez mais uma tradição perdida do insólito na literatura brasileira, ainda é possível afirmar que carecemos de uma forte produção de horror sobrenatural no país. Dessa forma, vampiros encontraram escasso terreno para se desenvolver, ficando restritos a alguns contos regionalistas e à literatura mais recente. No entanto, se retomarmos, agora, essa 
paridade entre o conteúdo da monstruosidade do vampiro e do psicopata, encontraremos em nossa literatura uma pródiga produção de obras centradas nos mesmos elementos culturais explorados por Drácula: o medo do lado animal do homem, o perigo de ser caçado nas ruas escuras da cidade e a ameaça sexual envolvida nesses ataques.

Nosso primeiro exemplo surge poucos anos após a publicação da obra de Stoker. Em 1906, João do Rio publica "Dentro da noite" na Gazeta de Notícias, conto que mais tarde servirá para nomear a coletânea de contos estranhos, obscuros e perturbadores do escritor. Nossa escolha é justificada pela clara alusão ao vampirismo que tematiza o conto: o protagonista - e monstro - da história descobre-se acometido por um desejo incontrolável de furar os braços de sua noiva, impulso que será levado a cabo e terminará transformando-o paulatinamente em um predador noturno. Se, como notou Bloom, é curioso que Drácula não apresente nenhum ponto de contato direto com os casos de Whitechapel, que possivelmente serviram para impulsionar os efeitos da obra, em "Dentro da noite" vale ainda ressaltar como o oposto ocorre. Apesar da clara referência ao vampirismo, nenhuma menção a Drácula ou qualquer outra obra vitoriana é encontrada - ainda que, como tradutor de Oscar Wilde, João do Rio tivesse claro contato com tal literatura. Veremos, no entanto, menção direta justamente ao par não sobrenatural do vampiro, comparando o protagonista ao temido estripador inglês e, assim, reforçando a ideia de que, tal figura encontraria paralelos com o conde criado por Stoker.

O conto narra o encontro entre Rodolfo e Justino em um vagão do trem nas noites cariocas. Rodolfo, o protagonista, já se encontra plenamente rendido ao seu lado bestial, transformado em um 
predador noturno, e encontrava-se ali justamente em busca de sua próxima vítima, "pálido, suando apesar da temperatura fria, e com um olhar tão estranho, tão esquisito" (RIO, 2002. p.17), como nota seu amigo. O conto, então, passa para uma narrativa em moldura, na qual Rodolfo contará como chegou àquela condição. Justino, mais que puro espectador, funcionará como contraponto à perspectiva de Rodolfo, justificando os atos de seu companheiro conforme o vê culpar-se pela situação em que se encontra.

Rodolfo confessa-se acometido por uma espécie de vício ou tara do qual não consegue livrar-se e não pode resistir. A nevrose, em termos de Rodolfo, eclode durante um baile ao qual havia ido com sua noiva, a submissa Clotilde. Vendo seus braços descobertos pela primeira vez, sente, subitamente, um desejo crescer dentro de si:

a vontade de tê-los só para os meus olhos, de beija-los, de acaricia-los, mas principalmente de fazê-los sofrer. Fui ao encontro da pobre rapariga fazendo um enorme esforço, porque o meu desejo era agarrar-Ihe os braços, sacudi-los, aperta-los com toda a força, fazer-lhes manchas negras, bem negras, feri-los... Porque? Não sei, nem eu mesmo sei - uma nevrose! (RIO, 2002, p.19)

Longe de entregar-se abertamente ao desejo, Rodolfo lutará contra o impulso monstruoso que toma sua vontade. Nesse conflito entre o Rodolfo civilizado e o instinto bestial que cresce em seu corpo, vemos de forma clara o medo desse lado animal do homem, talvez de forma mais impactante do que aquela encontra nos monstros sobrenaturais: mesmo sem nenhuma mudança ontológica, o ser humano estaria suscetivel a se transformar em um monstro sem que nada pudesse fazer para lutar contra tal condição ou preveni-la. 
Conforme o tempo passa, a nevrose que de início era um impulso bruto, depura-se em um desejo sádico refinado:

Contive-me dias, meses, um longo tempo, com pavor do que poderia acontecer. O desejo, porém ficou, cresceu, brotou, enraigou-se na minha pobre alma. No primeiro instante, a minha vontade era bater-lhe com pesos, brutalmente. Agora a grande vontade era de espetá-los, de enterrar-Ihes longos alfinetes, de cozê-los devagarinho, a picadas (RIO, 2002, p.19)

Nessa sutil tortura encontraremos a grande proximidade com o vampiro. O ato inaugural, cometido pouco depois contra Clotilde não só cria uma alusão ao ato sexual semelhante à da mordida do vampiro como o próprio Rodolfo indica a possibilidade de beber o sangue, confirmando o paralelo com o monstro sobrenatural: "É preciso pagar ao meu ciúme a sua dívida de sangue. Deixe espetar o alfinete." "Está louco, Rodolfo?" "Que tem?" "Vai fazer-me doer." "Não dói." "E o sangue?" "Beberei essa gota de sangue como a ambrosia do esquecimento." (p.20)

É no contraponto de Justino que vemos a menção a dois nomes próprios do lado não sobrenatural das ansiedades sobre o lado bestial do homem, Sade e Jack o estripador. O amigo de Rodolfo, como os vilões de Sade, usa as próprias ferramentas da razão para justificar o ato hediondo:

- Caso muito interessante, Rodolfo. Não há dúvida que é uma degeneração sexual, mas o altruísmo de S. Francisco de Assis também é degeneração e o amor de Santa Teresa não foi outra coisa. Sabes que Rousseau tinha pouco mais ou menos esse mal? És mais um tipo a enriquecer a série enorme dos discípulos do marques de Sade. Um homem 
de espírito já definiu o sadismo: a depravação intelectual do assassinato. És um Jack-the-rippercivilizado, contentas-te com enterrar alfinetes nos braços. Não te assustes (p.21)

Rodolfo, após o fim de seu noivado com Clotilde devido à descoberta das torturas por parte de uma empregada da família, passará, como Jack, a buscar suas presas entre as prostitutas da cidade. No entanto, numa fase intermediária de sua nevrose, não as ataca, mas tenta pagar para ter seu desejo saciado, proposta que rapidamente será descartada por aquelas mulheres, que sentiam repulsa pelo vício de Rodolfo.

Assim, o personagem acaba entregando-se plenamente à sua condição e passa a buscar as vítimas nas estações e vagões de trem, alcançando assim, o ponto em que se encontrava no momento de sua narração. A conversa é interrompida com a passagem de uma jovem loira, que atiça o desejo de Rodolfo. Ele despede-se de seu amigo, descendo na mesma estação de sua possível presa. O conto se encerra entre a expectativa dos gritos da vítima e a partida do trem pela noite, deixando em aberto o destino do monstro e sua vítima na noite carioca.

Ainda que João do Rio tenha outras obras que dialogam com os medos vitorianos destacados anteriormente - como o sádico Barão Belfort, que vampiriza a emoção de suas vítimas por uma incapacidade de sentir qualquer coisa por conta própria, ou a enigmática femme fatalle de "O carro da semana santa", explorando a temática do sexo e da heresia -, vale destacar que tal diálogo se manifesta em outros autores e períodos da literatura brasileira. Dentre eles, gostaríamos de destacar Lúcio Cardoso. 
Herdeiro do gótico urbano de João do Rio, o autor mineiro, mais conhecido por sua produção regionalista, têm, na trilogia do Mundo sem Deus - composta por Inácio, $O$ enfeitiçado e o incompleto Baltazar - a representação de um Rio de Janeiro tão decadente, corrupto e sombrio quanto vemos em Dentro da noite. No entanto, a proximidade mais peculiar de Lúcio Cardoso com o autor carioca se dá por um conto secundário de sua produção, publicado em 1946 no suplemento literário do jornal A manhã e republicado no mesmo espaço quatro anos mais tarde com algumas alterações ${ }^{10}$.

"A papoula azul", posteriormente nomeado "Simples encontro", apresenta em uma breve narrativa o caso de uma menina que, durante um piquenique na praia, é atraída por um homem misterioso que contrastava com a paisagem idílica em que se encontravam:

Era magro, alto e, menos do que sua estranha atitude de observação, o que nele me chamou a atenção desde o início foi o chocante contraste que oferecia com a paisagem: não havia nada em sua pessoa que lembrasse a claridade e a alegria que nos cercava, ao contrário, vestia-se severamente de preto e escondia mais ou menos o rosto à sombra de um chapéu também preto (CARDOSO, 1946, p.7)

Tal figura, além do contraste sombrio, se destacará por alguns paralelos que o aproximam dos vampiros vitorianos, como sua capacidade hipnótica - "Pouco a pouco senti que ele exercia certa atração sobre mim e, quase sem querer, e sem saber porque o fazia, fui me aproximando aos poucos" (p.7) - e sua palidez incomum - "Ao mesmo tempo que eu falava, pensava comigo mesmo: 'É um doente, só pode ser um doente. Nunca vi ninguém tão pálido assim..." (p.7).

10 E, cuja descoberta, eu devo ao prof. Julio França, que primeiro notou o paralelo entre ambos. 
É, no entanto, o desfecho do conto que mais chama a atenção. A misteriosa figura, através dessa atração inexplicável, conduz a menina para longe de seus amigos sobre o pretexto de ver uma papoula. Mesmo sabendo que papoulas não crescem ali, ela deixase levar até $\mathrm{o}$ alto de alguns rochedos marinhos, onde a ataca:

Ele se aproximou, como para mostrar-me a flor:

- Ali, bem ali.

Olhei de novo - e desta vez, senti de repente uma dor aguda, horrível, atravessar-me o braço. Dei um grito, sem compreender o que fosse, e erguendo-o, vi que o homem tinha enterrado nele um comprido e negro espinho de cactos (CARDOSO, 1946, p.7)

Dada a proximidade de temáticas e estilos dos autores e o inegável paralelo entre o modus operandi do psicopata de "Dentro da noite" e do misterioso homem de "A papoula azul" - além de um mesmo perfil de vítima -, podemos supor que o conto de Lúcio Cardoso fizesse, 25 anos após a morte de João do Rio, uma homenagem velada ao autor carioca, criando uma pequena reaparição de Rodolfo.

É, no entanto, Inácio, personagem central nos três romances da trilogia "O mundo sem Deus", que nos oferecerá um retrato mais completo do predador urbano cardosiano. Ao longo dos três romances, devido à diferença de foco narrativo, temos acesso a três perspectivas distintas do monstro que será Inácio: o monstro enquanto ameaça externa; o monstro enquanto besta interna; e as cicatrizes deixadas pelo monstro.

Em Inácio, vemos o personagem através da ótica de seu filho, Rogério, enquanto vamos sendo apresentados ao passado 
de Inácio, mediado pelo discurso de um homem que quer matálo, Lucas Trindade. Nesse romance, as caracterizações do pai de Rogério oscilam entre a repulsa, carregada de ódio pelo passado, e uma atração irresistivel, que faz com que Rogério, mesmo alertado sobre os pecados de seu pai, queira aproximar-se dele novamente. Inicialmente influenciado pelo ódio e medo de Lucas Trindade, que Rogério descobre ser antigo amante de sua mãe, Inácio é descrito como um ente quase sobrenatural:

- Vamos - disse Lucas -, pois tenho medo de não me controlar. Nem sabe você de que poderes é dotado esse demônio!

- Não acredito nos seus poderes - respondi eu, mais para atiça-lo do que mesmo por dar crédito às minhas palavras.

- Não? Pois há vários anos que não me abandona, que me persegue dia e noite, sem descanso. Até em sonhos me aparece. E como zomba de mim, como se ri, como bebe e vive satisfeito, esse monstro! $\mathrm{E}$ sempre o vi assim, com essa fisionomia que jamais envelhece, com o mesmo olhar e a mesma cara de boneca! (CARDOSO, 2002, p.86-87)

A descrição de Lucas, logo depois, é confirmada por Rogério que encontra na fisionomia do pai a mesma impressão perturbadora atestada pelo antigo inimigo de Inácio:

vi seu rosto pálido como se fosse de cera, corado ao centro, um rosto realmente de boneca, mas iluminado por tal expressão de ódio como jamais vi numa fisionomia humana. Não, ali falava alto alguma coisa mais extraordinária que a simples força que agitava o coração humilhado de Lucas... Aliás, devo declarar que a proximidade daquele homem causou-me uma espécie de estupor: não 
podia me mover, olhos cravados no seu rosto, no seu rosto horrendo, que eu tanto vira transitar nos meus pesadelos de criança (p.88)

Vemos nas descrições de Lucas e Rogério como, novamente, esse predador urbano cardosiano apresenta traços da caracterização dos vampiros em sua formação. Inácio apresenta uma fisionomia que jamais envelhece, um rosto pálido "como se fosse de cera" e seu olhar é capaz de causar "uma espécie de estupor".

Aproximando-se de Rogério a fim de descobrir o paradeiro de Lucas Trindade, Inácio mostrará também seu lado sedutor, dividindo a opinião do filho sobre ele:

Não sabia dizer se aquele homem me atraía ou causava repulsa. O certo é que suas possibilidades causavam-me uma singular fascinação (...). Devo declarar também que, nele, uma das qualidades que mais me impressionavam era a sua capacidade de transfiguração; ainda que se tratasse do fato de tomar uma laranjada, para Inácio esse episódio banal se convertia em algo de estranho e maravilhoso (p.110)

Ao fim da obra, após Lucas ter sido assassinado por Inácio com a ajuda do filho, Rogério perde a utilidade que tinha e, assim, Inácio parece deixar de esforçar-se para agradar o filho. Livre da influência magnética do pai e ainda traumatizado pela cena do assassinato, Rogério percebe pouco a pouco o monstro que era seu pai e, atormentado por aquele vislumbre, enlouquece. Descobrimos, assim, que o garoto narra a história de um sanatório no qual se encontrava internado após os eventos apresentados no romance. 
O segundo livro da trilogia inverte drasticamente essas perspectivas. Em $O$ enfeitiçado, quem narra é um Inácio mais velho, já esgotado pelos anos, arrependido de seu passado e buscando no reencontro com o filho perdido uma forma de redenção. $\mathrm{Na}$ perspectiva do próprio monstro, como no caso de "Dentro da noite", vemos ganhar destaque não o medo de tornar-se vítima, mas o medo dessa besta interior que pode eclodir de qualquer homem, o medo de que nos tornemos, de uma hora para outra, um monstro.

Nessa obra, intensificam-se algumas das características que aproximam Inácio do monstro vampiresco. Se em Inácio o ambiente já era carregado de sombras, vemos na segunda obra um protagonista plenamente notívago:

E era tarde, era quase noite, ou melhor, era precisamente essa hora que eu tanto amo, hora em que as ruas escurecem e a [sic] luzes se acendem. Nunca pude ficar em casa nesse momento. É preciso amar as cidades para adivinhar as horas em que palpita seu segredo mais fundo. É preciso ter os olhos bem abertos, os ouvidos à escuta, para perceber quando o mar se cala e a noite chega, com suas promessas e possibilidades. Ninguém saberá jamais o que é a noite para os noctívagos: eles se roçam nela, embriagam-se com sua cálida essência, resplandecem aos seus fogos concentrados. Desmesuradas, àquela hora as casas abrigavam a sombra (CARDOSO, 2002, p.156)

Dir-se-ia que uma ausência enorme se fizera no mundo, que uma única noite, vasta e repleta de silêncio, cobrira para sempre os meus passos (p. 200)

Visitando Lina, uma cartomante, a fim de tentar obter informações através de sua rede de contatos, esta vê em Inácio alguém que buscava 
"algo fundamental, como que o próprio alento da sua vida..." (p.169). Posteriormente Lina especifica mais, dizendo que "Ihe falta um elemento vital, um calor para este sangue que lhe corre nas veias" (p.207), e chega a conclusão: “O senhor não está vivo” (p.207).

Esse alento de vida será roubado de Adélia Val-Flor, suposta filha da cartomante, que lhe é apresentada como parte de um plano da mãe para extorquir-lhe o dinheiro. Inácio passa a levar Adélia para passear, ainda que a filha da cartomante seja, nas suas palavras, "uma criança, uma criança no sentido exato da palavra, tímida e mal vestida" (p.174). Conforme Inácio convivia com Adélia, projetava nela uma maturidade que claramente lhe faltava e, ao mesmo tempo, sentia-se mais vivo e afastado de seus tormentos. Esse processo, contudo, culmina naquilo que Lina esperava: Inácio, sentindo a necessidade de possuir Adélia, resolve comprá-la definitivamente. Pouco depois, começava a surgir em sua mente a consciência do desejo que se formava nele e, assim, a besta interior que voltava, depois de tantos anos, a atacar-lhe:

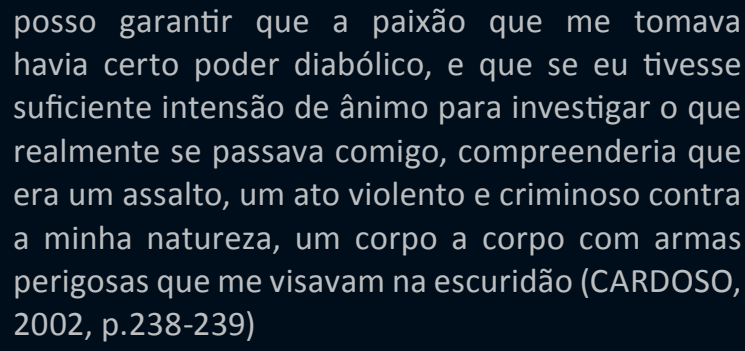

Inácio, tomado pelos impulsos, resolve embebedar a menina e levála para sua casa. Enquanto está desmaiada pelo álcool a ataca. Aqui, o que na literatura vampiresca é metáfora sexual, descarta a necessidade de símbolos e expõe um verdadeiro estupro à menina desacordada: 
Tive a impressão de que outra força me conduzia e me fazia agir, independente da minha vontade. Inclinei-me sobre Adélia adormecida e, tomando-a nos braços, colei à sua boca meus lábios ávidos. Aquele beijo não tinha gosto de coisa alguma, mas eu sentia palpitar junto à minha carne aquela vida cheia de calor e de intensidade, o que me dava momentaneamente uma sensação idêntica à da embriaguez. E confesso que não tive nenhum pudor, nenhum remorso em profanar aquele corpo de criança (p.249)

Baltazar não chegou a ser terminado por Lúcio Cardoso, mas, através dos trechos que já haviam sido produzidos pelo autor, é possível ver que o foco da narrativa seria justamente na vítima de Inácio, Adélia. Já mais velha, Adélia nunca consegue deixar para trás as marcas do ato a que foi submetida e vive uma vida marcada pelo trauma. Inácio, que morre no final de $O$ enfeitiçado após ser obrigado a se enforcar por um capanga de Lina como punição por não pagar a dívida contraída com ela, reaparece em Baltazar como um espectro na memória e nos pesadelos da menina:

Foi nesse instante, que senti a sua presença: talvez seja melhor dizer que senti a mesma impressão de antigamente, quando me diziam que "ele" estava na sala - e através da cortina, eu espiava o seu vulto detestado (p.297)

Não sei que esquisita emoção se apoderava de mim, mas era uma espécie de vertigem, um esmaecimento de todos os meus nervos, como se eu tivesse ingerido um narcótico. Sem dúvida era a presença daquele homem, tão forte, tão absoluta nas suas vagas de terror e de exaltação, o que produzia aquele sentimento de cansaço ou de embriaguez (p.299-300) 
Encerra-se assim a representação desse monstro urbano tanto em sua potencialidade, em Inácio, em sua concretização em 0 enfeitiçado e em suas reminiscências nos trechos de Baltazar. Se, em "Dentro da noite", a agulha servirá como proximidade com o ato vampiresco, Inácio abunda em índices que o aproximam de Drácula, velho aristocrata perdido em um Rio de Janeiro com ares de Londres gótica. Tal semelhança pode ainda ser reforçada se levarmos em conta que Lúcio Cardoso foi tradutor da obra de Stoker, tornando inegável sua relação com o romance vitoriano.

Pode-se ainda, para completar um percurso pelos predadores urbanos como figuras vampirescas na literatura brasileira, abordar uma obra mais recente: $O$ vampiro de Curitiba, de Dalton Trevisan. Seu título, assim como certo discurso difundido ao longo da obra, condensa justamente nossa hipótese sobre o conteúdo dos medos, ansiedades e desejos relacionados ao vampiro vitoriano.

Coletânea de contos, fragmentos da vida de Nelsinho, "O vampiro de Curitiba" usa o monstro vitoriano justamente como metáfora para um desejo incontrolável que tortura o personagem: o sexual. Em um longo fluxo de pensamento, o primeiro conto serve mais como manifesto da mente pervertida, como confissão que nos ajudará a ler seus atos nas histórias que se seguirão. Em tom delirante, expõe de forma truncada o misto de ódio e paixão que parece sentir por toda e cada mulher da rua, especialmente pelas mais novas, pelas virgens. Encara sua mera presença como provação e, diante daquilo que parecem despertar em seu interior, afirma:

Se não quer, por que exibe as graças em vez de esconder? Hei de chupar a carótida de uma por uma. Até lá enxugo os meus conhaques. Por causa 
de uma cadelinha como essa que aí vai rebolandose inteira. Quieto no meu canto, ela que começou. Ninguém dia que sou taradinho. No fundo de cada filho de família dorme um vampiro - não sinta gosto de sangue (TREVISAN, 1998, p.10)

O vampiro serve, assim, como símbolo para essa besta sexual que na visão de mundo de Nelsinho, habitaria no interior dos homens de forma geral. Se em cada filho de família habita um vampiro, Nelsinho completa sua teoria afirmando sobre as meninas que "[t]oda família tem uma virgem abrasada no quarto" (p.13).

No entanto, como veremos ao longo do livro, essa máxima representa apenas metade do universo feminino da obra. Para Nelsinho, as mulheres se dividem necessariamente entre o arquétipo da virgem - inocente, recatada, provocante - e o arquétipo da viúva, tão vampira quanto os rapazes, caçadora insaciável:

Não olhe, infeliz! Não olhe que você está perdido. É das tais que se divertem a seduzir o adolescente. Toda de preto, meia preta, upa lá lá. Órfã ou viúva? Marido enterrado, o véu esconde as espinhas que, noite para o dia, irrompem no rosto - o sarampo da viuvez em flor. Furiosa, recolhe o leiteiro e o padeiro. Muita noite revolve-se na cama de casal, abana-se com leque recendendo a valeriana. Outra, com a roupa da cozinheira, à caça de soldado pela rua (p.11)

De fato, se olharmos para a dinâmica de predador e presa ao longo das obras, a coletânea poderia muito bem se chamar Vampiros de Curitiba, uma vez que esse segundo tipo de mulher, experimentadas, donas de sua própria sexualidade, atacarão ao jovem e inexperiente Nelsinho tanto quanto ele o fará com as virgens que consegue conquistar. 
Nelsinho, de certa forma, incorpora um pouco de cada um de seus antecessores. Em sua loucura pelas virgens, protagonizará atos de violência sexual como aquele que marca Inácio e, atormentado por seus impulsos sexuais incontroláveis, se aproximará da psicopatia de Rodolfo. Por mais que o rapaz não encontre o refinamento sádico do personagem de João do Rio, parece haver, ao menos em seu discurso, grandes semelhanças entre os impulsos de ambos: "Ó bracinho nu e rechonchudo - se não quer por que mostra em vez de esconder? -, com uma agulha desenho tatuagem obscena" (TREVISAN, 1998, p.12).

A obra oscila entre episódios humorísticos, eróticos e mais sérios. Em dois deles, podemos ver com mais claridade o lado predatório de Nelsinho se desenvolvendo de forma mais ameaçadora. Em "Incidente na loja", tenta seduzir uma jovem vendedora, mas não resistindo ao impulso sexual que the vem e aproveitando que a loja estava vazia, leva-a ao fundo e estupra a menina, ainda que, de seu ponto de vista, tente convencer-se que ela queria e que, na verdade, ele seria a vítima: Óculo embaçado da moça, estava de olho aberto? Ela não se mexia, ofegante de medo ou prazer. Nelsinho enterravaIhe o nariz nos longos cabelos vermelhos - ai, Senhor, de nós dois qual é a vítima? (p.21)

No segundo episódio, muito mais violento, a presa é uma menina negra de dezesseis anos, vítima de um estupro coletivo do qual Nelsinho é um dos culpados. "Debaixo da ponte preta" é narrado na forma de sucessivas versões do caso, dadas na forma de depoimentos para o delegado que então investigava o caso. Vemos nesse conto novamente a tentativa de amenizar a culpa dos criminosos alegando - em algumas das versões - que a menina 
namorava um dos rapazes ou era uma prostituta ou ainda que o tinha feito por vontade própria. No entanto, através da repetição constante do mesmo horrendo ato, o conto transmite de forma incisiva o medo sentido por essas vítimas dos homens-vampiros que povoam a urbe, criaturas que, parecendo homens civilizados - casados, trabalhadores, servidores da justiça ou simples meninos - não precisam mais do que uma pequena oportunidade para transformarem-se em monstros:

Miguel de Tal, quarenta anos, casado, foguista, largou o serviço às dez e meia. Ao cruzar a linha do trem, avistou três soldados e uma dona em atitude suspeita. Sentiu um tremendo desejo de praticar 0 ato. Aproximou-se do grupo e, auxiliado pelos soldados, agarrou a desconhecida, retirando-Ihe a roupa e com ela mantendo relação, embora à força. Derrubou-a e, para abafar os gritos, tapou-Ihe o rosto com o casaco de foguista. Saciado, ajudou os soldados que, cada um por sua vez, usaram a moça, observados à distância por alguns curiosos, até que dois deles também se serviram da negrinha (TREVISAN, 1998, p.77)

Ainda que a literatura brasileira ofereça inúmeros casos de assassinos, psicopatas e estupradores, muitos dos quais conseguiriam ser mais próximos à brutalidade dos atos de Jack, optamos por selecionar esses três a fim de ilustrar não apenas como os temores encontrados na literatura vampiresca vitoriana se perpetuaram ao longo do tempo através da literatura centrada em predadores urbanos, como também para mostrar como mesmo que o vampiro enquanto forma não seja utilizado com frequência em nossa literatura, sua apropriação enquanto metáfora, enquanto signo que aponta para esse monstro vitoriano, se dá não apenas na 
virada do século, mas continua até hoje servindo como associação aos medos que anteriormente já expressava.

Se o Brasil não pode ser visto como um país em que vingaram muitas narrativas sobre vampiros, não nos faltaram alternativas para manifestar o conteúdo dos medose anseios culturais inspirados por essas criaturas: atendendo à demanda pelo documental, essas narrativas mostram que o dom proteico do vampiro pode ir além de suas metamorfoses usuais, permitindo que mesmo fora do campo sobrenatural, seus horrores se manifestem através de um monstro assustadoramente humano.

\section{REFERÊNCIAS}

BLOOM, Clive (2017). "Dracula and the Psychic World of the East End of London". In: CRIŞAN, Marius-Mircea. Dracula: an international perspective. Londres: Palgrave MacMillan, p.119-137.

CARDOSO, Lúcio (1946). "A papoula azul”. A manhã, Suplemento Letras e artes, 25.Ago, 7.

(2002). Inácio, O enfeitiçado e Baltazar. Rio de Janeiro: Civilização Brasileira.

CAWELTI, John (1975). "The New Mythology of Crime". Boundary 2, 3(2), 324-357. COHEN, Jerome Jefrrey (2000). "A cultura dos monstros: sete teses". In: SILVA, Tomaz Tadeu da (Org.). Pedagogia dos monstros: os prazeres e os perigos da confusão de fronteiras. Belo Horizonte: Autêntica. p.23-60.

COLAVITO, Jason (2008). Knowing Fear: Science, Knowledge and the Development of the Horror Genre. Jefferson, NC: McFarland.

FRANÇA, Julio (Org.) (2017). Poéticas do mal: a literatura do medo no Brasil (1840-1920). Rio de Janeiro: Bonecker.

RIO, João do (2002). Dentro da noite. São Paulo: Antiqua.

SADE, Marquês de (1979). Justine: ou as desgraças da virtude. Edmond Jorge (Trad.). Rio de Janeiro: Entrelivros cultural. 
SIMPSON, Philip (2010). "Noir and the Psycho Thriller". In: HORSLEY, Lee; RZEKPA, Charles (Org.). A companion to Crime Fiction. Chichester: Wiley-Blackwell. TREVISAN, Dalton (1998). O vampiro de Curitiba. Rio de Janeiro: Record. 


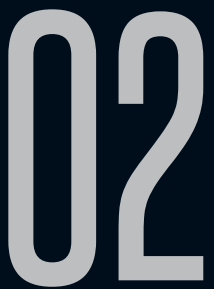

\section{DEU IMPRINTING!': VAMPIROS, LITERATURA BEST-SELLER E CONVERGÊNCIA DAS MÍDIAS A PARTIR DO FENÔMENO JUVENIL THE TWILIGHT SAGA}

Jennifer da Silva Gramiani Celeste (UFJF) Juliana Gervason Defilippo (UFJF)

Recebido em 13 mar 2019. Jennifer da Silva Gramiani Celeste é Doutoranda em Aprovado em 08 mai 2019. Letras (Estudos Literários) pela Universidade Federal de Juiz de Fora (UFJF). É atuante no que se refere às interfaces dialógicas entre Literatura e Internet, ademais, Cultura da Convergência, Cultura de Massa, Educação na Cibercultura e Adolescência. É Membro Pesquisadora do Grupo de Pesquisa "A Literatura e os Cibercaminhos", sediado pelo Programa de Mestrado em Letras (Literatura Brasileira), pertencente ao Centro de Ensino Superior de Juiz de Fora. Lattes: http://lattes.cnpq.br/3592548159560060 Blog: http:// entrelinhasentrepautas.blogspot.com.br

Juliana Gervason Defilippo é Pós-Doutoranda em Literatura, Cultura e Contemporaneidade pela Pontifícia Universidade Católica do Rio de Janeiro (PUC-RJ). É Professora e Coordenadora Adjunta do Programa de Mestrado em Letras (Literatura Brasileira) do Centro de Ensino Superior de Juiz de Fora (CES/JF), bem como também Editora-Gerente da CES

1 No universo de Twilight, o termo Imprinting se refere a uma espécie de forte conexão a qual comumente ocorre entre seres sobrenaturais - tais como vampiros e lobisomens - e seres humanos. 
Revista (ISSN 1983-1625 - Qualis B1 e outros estratos). Possui experiência na área de Letras, atuando com os cotejos transdisciplinares viabilizados pelos Estudos Literários, com destaque para as interfaces dialógicas entre Literatura e Internet, Literatura e Diversidade e Literatura Feminina. É Líder do Grupo de Pesquisa "A Literatura e os Cibercaminhos", sediado pelo Programa de Mestrado em Letras (Literatura Brasileira), pertencente ao CES/JF. Lattes: http:// lattes.cnpq.br/2636818119719002

Resumo: The Twilight Saga, nacionalmente conhecida como A Saga Crepúsculo, idealizada pela escritora norte-americana Stephanie Mayer, mobilizou a indústria literária e do entretenimento em meados do ano de 2008, quando lançada no Brasil. Entre seres humanos, vampiros e lobisomens, Twilight impactara a Literatura Juvenil, assim como conduzira a imersão de jovens no universo literário, estes, até então pouco adeptos e cativos às práticas de leitura. Defronte a este contexto, o presente artigo objetiva dissertar e refletir acerca da dinâmica de produção literária dedicada aos jovens a partir do fenômeno da coleção Crepúsculo (2008), considerando, para tanto, a abordagem de temas sobrenaturais na Literatura em meio ao sistema cultural de convergência das mídias. Palavras-chave: Literatura Juvenil; Convergência das Mídias; The Twilight Saga.

Abstract: The Twilight Saga, nationally know as A Saga Crepúsculo, created by north-american writer Stephanie Mayer, mobilited the literary's and entertainment's industries in 2008's years, when launched in Brazil. Among humans, vampires and werewolfs, Twilight impacted the Juvenile Literature, as well as led to immersion of youngs on literary universe, until then little adepts and captives at reading practices. In this context, the present article aims to discuss and reflect on the dynamics of literary production dedicated to young people from de phenomenon of 
the Twilight Saga, considering, therefore, the approach of supernatural themes in Literature in the cultural system of media's convergence.

Keywords: Juvenile Literature; Convergence of Media; The Twilight Saga.

\section{INTRODUÇÃO}

The Twilight Saga, a série vampiresca escrita por Stephanie Mayer, tornou-se um ícone literário de uma geração e transgressor de balizas impostas à Literatura Juvenil, tal como outrora fora considerada a mágica trajetória do jovem bruxo Harry Potter. Os livros impactaram a vida de adolescentes pouco cativos às práticas de leitura, tendo sido traduzidos no Brasil pela editora Intrínseca no ano de 2008 sob o título de Crepúsculo.

Mesmo após dez anos desde a primeira publicação de Crepúsculo (2008) no Brasil, ainda é possível verificarmos os vestígios do legado da história de romance e guerra entre vampiros, lobisomens e seres humanos, especialmente no que concerne à inserção de jovens no âmbito literário, assim como ao processo de formação destes indivíduos enquanto leitores, ou ainda, ao aquecimento do mercado de consumo e das comunicações, haja vista a idealização de produtos, demais coleções literárias, filmes e seriados televisivos cujos pilares se instituíram com base na apresentação de temas congêneres. Das páginas dos livros impressos às telas dos cinemas, televisores e dispositivos de natureza eletrônica, as personagens e o enredo de Twilight fazem-se presentes e se renovam a cada acesso, visualização, curtida ou compartilhamento na grande rede de computadores, confirmando as viabilidades de ser e estar jovem, leitor e, também, nativo e conivente à era digital. 
Ao vislumbrarmos este panorama, no presente artigo nos propomos a suscitar algumas reflexões acerca do alcance desta franquia literária no que se refere à abordagem de temáticas sobrenaturais na Literatura produzida em contexto de convergência midiática.

\section{O VAMPIRESCO E O SOBRENATURAL NA LITERATURA BEST-SELLER}

Afinal, o que há por detrás do fenômeno Twilight? Esta e outras tantas indagações de semelhante natureza pairam sobre a atmosfera sobrenatural a qual acolheu milhares de jovens de diferentes nacionalidades, sedentos não por sangue, tal como comumente o fazem os vampiros, mas sim por títulos literários a eles exclusivamente dedicados. O sucesso alcançado por esta franquia literária indubitavelmente se figura como fator de primordial análise para que possamos nos tornar capacitados a compreender e a debater seu poder sobre a produção literária juvenil na contemporaneidade digital.

O estudioso Franco Moretti é aquele quem nos auxilia quando na obra de sua autoria, intitulada A literatura vista de longe (2008), discorre a respeito do elemento denominado pattern ${ }^{2}$. Segundo Moretti (2008), evento, ciclo e longa duração são reconhecidamente dimensões temporais as quais obtiveram distintas sortes no âmbito da história da Literatura. Ainda que questões atreladas aos eventos e à longa duração tenham sido exploradas adequadamente no meio acadêmico, "[...] o tempo do ciclo, permaneceu, ao contrário, em boa medida inexplorado [...]" (MORETTI, 2008, p.31). Algo interessante, já que é por intermédio deste que podemos melhor desbravar circunstâncias de produções literárias similares a 
Crepúsculo (2008) e a outros demais títulos. Moretti (2008), porém, justifica-se, salientando que a crítica literária até então não havia sido capaz de imergir na especificidade característica dos ciclos, pois estes "[...] constituem estruturas temporárias internas ao fluxo contínuo da história [...]" (2008, p.31 - grifo do autor).

Os ciclos os quais se desenvolvem nos meandros da Literatura, conforme assim nos apresenta Moretti (2008, p.34), são estruturas que comportam repetições e, portanto, peculiaridades como regularidade, ordem e forma. Deste modo, torna-se facilmente compreensível o motivo pelo qual acontecera o expressivo lançamento de livros, paralelo aos volumes da saga Crepúsculo (2008), os quais também contemplavam enredos e personagens comuns ao universo dos vampiros. Tendo em vista o sucesso alcançado por Twilight, somos capazes de supor que livros sobre a classe de vampiros, engavetados por distintas e desconhecidas razões, puderam vir à tona e aproveitar a circunstância de boa crítica e recepção quanto à abordagem deste tema na Literatura - e, por óbvio, aqui citamos a favorável dinâmica do mercado literário impresso vigente à época. llustrativamente, podemos mencionar a série Academia de vampiros (Agir, 2007), produzida por Richelle Mead; o livro Morto até o anoitecer (Ediouro, 2009), de Charlaine Harris, aclamado por dar origem ao célebre seriado televisivo True Blood; a saga House of night (Novo Século, 2007), da autoria de P. C. Cast; e, por fim, os volumes pertencentes à série teen feminina intitulada Insaciável (Record, 2011), idealizada pela escritora Meg Cabot ${ }^{3}$.

São temporários os ciclos, pois seus cursos são breves ou podem se estender por dez, vinte ou até mesmo cinquenta anos,

3 Destacamos novamente que a obra de Stephanie Mayer originalmente fora publicada no ano de 2005. 
nos aponta Moretti (2008, p.31). De fato, transcorridos um ou dois anos após a publicação do primeiro volume de Twilight, o frenesi observado em torno da Literatura de cunho vampiresco, cessara. Entretanto, é preciso reconhecermos: a abordagem sobrenatural se constituíra algo de tamanha grandiosidade, tanto que, até os dias atuais, escrever sobre vampiros ou lobisomens personagens também presentes na obra de Mayer - ainda está em alta $^{4}$. Um exemplo é a existência de searas específicas a este tipo de Literatura em redes de interação social voltadas à publicação literária no ambiente eletrônico, como Wattpad ${ }^{5}$. Parcialmente, também podemos atribuir este fato à possibilidade de manifestação literária no ciberespaço por meio da escrita de fanfics, claramente impulsionada pelo intricado sistema cultural e participativo de fãs.

Para além deste cenário, citamos alguns livros lançados após o fenômeno Twilight, os quais também contemplam narrativas de cunho sobrenatural, como é o caso dos títulos literários A maldição do tigre (Arqueiro, 2011), de Colleen Houck; Sangue quente (Leya, 2012), de Isaac Marion - inclusive adaptado para as telas do cinema no ano de 2013, sob o título Meu Namorado é um Zumbi, sucesso entre os adolescentes; e Os instrumentos mortais (Record, 2013), de Cassandra Claire. Na mídia televisiva, a produção de séries teen sobrenaturais também passara a se fazer demasiada frequente. Em relação a este fato, citamos Teen Wolf, The Secret Circle, Shadowhunters, True Blood e The Vampire Diaries.

4 Para além da exemplificação a qual apresentamos a seguir no texto, também podemos mencionar a editora brasileira Dark Side, hoje tida como uma das principais responsáveis pela popularização de títulos literários, entre estrangeiros e nacionais, tocantes ao terror e ao suspense.

5 A exemplo disto, recomendamos o acesso ao seguinte link: https://www.wattpad. com/stories/vampiros Acesso em 15.Mar.2019. 
Aliás, na década de 1990, o seriado Buffy, The Vampire Slayer ${ }^{6}$ - símbolo da cultura pop norte-americana -, apresentava-nos uma protagonista bastante atuante, de forma ainda isolada e sob atmosfera ímpar, combatendo vampiros, demônios e demais forças advindas das trevas. O êxito alcançado por esta produção levara uma de suas principais personagens, Angel, a ganhar seu próprio spin-off. É caro também nos lembrarmos que Buffy e Angel protagonizam um romance épico e proibido por se tratarem de uma humana e um vampiro - acontecimento este que nos alude à história apresentada por Mayer em Twilight.

Averiguamos que ainda que Crepúsculo (2008) tenha sido absolutamente responsável pelo renascimento desta temática na Literatura - e aqui nos referimos, obviamente, à manufatura literária desenvolvida a partir do novo milênio -, outrora o mote sobre vampiros também se presentificara no curso da história literária. Anne Rice, autora de As crônicas vampirescas (Rocco, 1976), e L. J. Smith, responsável pela série Diários do vampiro (Galera Record, 2009) - originalmente publicada em 1991 -, são alguns exemplos de escritoras as quais já haviam se aventurado por este universo. Remetendo-nos a temporalidades ainda mais pretéritas, se figuraria expressivo equívoco nos olvidarmos do conto The Vampyre, de John William Polidori, responsável por expandir, há aproximadamente duzentos anos, as possibilidades de escrita sobre o tema em destaque - o escritor é reconhecido como um dos precursores quanto às produções deste gênero, tendo sido influenciado por algumas das produções escritas da autoria de Lord Byron.

6 Traduzido no Brasil como Buffy, a Caça-Vampiros. 
Moretti (2008) nos explica que os ciclos se iniciam caso as formas precedentes já tenham praticamente se esgotado. Em alguns casos, segundo o pesquisador, longas décadas de espera se fazem necessárias, "[...] provavelmente porque enquanto uma forma hegemônica não perdeu o seu valor artístico, as formas rivais não têm muitas cartas para jogar [...]" (2008, p.32 - grifo do autor). Claramente, é possível que algum evento excepcional ocorra como os booms de A menina que roubava livros (Intrínseca, 2007) ou A cabana (Sextante, 2008) -, mas é certo que estas exceções dificilmente deterão força e poder suficientes para transformar por completo o sistema em constância.

Comprovando a veracidade deste fato, aqui nos recordamos que já em meados do ano de 2010 fizeram-se perceptiveis os distintos lançamentos literários ainda atrelados à temática sobrenatural, embora com a presença de outras criaturas misteriosas como protagonistas, os anjos. Seres humanos e celestes protagonizavam histórias cujos enredos se desenvolviam em atmosfera apocalíptica e obscura, em meio à guerra entre céu e terra. As obras foram cativas ao público jovem, o qual pudera selecionar entre diversos títulos, desde os livros da série escrita por Lauren Kate, Fallen (Record, 2010); aqueles pertencentes à quadrologia da autoria de Becca Fitzpatrick, Hush, hush (Intrínseca, 2011); e a coleção de seis volumes, Fallen angels (Universo dos Livros, 2011), assinada por J. R. Ward.

O momento histórico também corresponde a elemento capaz de influenciar a dinâmica literária7. Para Moretti (2008, p.41),

7 Não nos olvidemos do massivo lançamento de obras literárias impressas resultantes da dinâmica de investimento literário na materialidade do conteúdo digital produzido por jovens celebridades e influenciadores digitais, em sua maioria, blogueiros e youtubers. 
quando específico gênero vem a substituir outro em particular, tendo isto ocorrido em determinada passagem histórica, podemos refletir quanto ao fato de que tal mutação acontece apenas por razões históricas e internas aos gêneros em questão. Afinal, "[...] coletâneas de cartas de amor têm muito menos sintonia com uma época revolucionária do que dramas sanguinários de vítimas inocentes e senhores cruéis [...]" (MORETTI, 2008, p.41). Embora haja sentido nesta assertiva, o excerto nos conduz a pensar em movimento contrário, no qual a Literatura se figura aquela responsável por ditar modismos de uma época - sobretudo no próprio campo de manifestação literária. Esta hipótese, então, se constitui detentora de maior fidedignidade, uma vez que quando a obra de Mayer fora publicada, não havia claros indícios de que a predileção pela abordagem de criaturas sobrenaturais e misteriosas, como os vampiros, se constituiria, talvez, uma forte tendência naquele momento. Retomando passagens anteriores do presente artigo, reiteramos o surgimento, em uma mesma época, de inúmeros títulos literários cujas temáticas e cujos elementos narrativos se assemelham entre si.

A densidade do fenômeno Crepúsculo (2008) se reverbera nesta atualidade. Aproximadamente dez anos se passaram desde a publicação do primeiro livro da saga, mas, ainda assim, os debates sobre as personagens, as histórias dos habitantes da cidade de Forks ou os vampiros dos clãs Cullen e Volturi se fazem presentes em fóruns online de discussão, rodas de conversa, diálogos em clubes literários, resenhas divulgadas em blogs ou canais do YouTube e fanfics compartilhadas em plataformas virtuais de redação e autopublicação literária, como Spirit Fanfics ou Wattpad. Portanto, entendemos que 
Twilight sobrevive em meio ao lançamento de tantas outras obras relativas à Literatura de viés sobrenatural, podendo ser considerada como responsável, na atual contemporaneidade, por viabilizar caminhos - relativos à escrita e, acima de tudo, mercadológicos - aos autores iniciantes e, por que não, já estabelecidos, que objetivem trazer à luz temas similares.

A obra de Stephanie Mayer se constitui latente no inconsciente coletivo de ávidos consumidores da Literatura Contemporânea. Crepúsculo (2008) é o best-seller de uma geração de jovens, muitos dos quais foram apresentados à prática da leitura a partir de tal obra e, por conseguinte, lograram imergir no universo literário graças ao seu enredo. Os leitores da saga vampiresca ainda continuam em cena e, por esta razão, mantém seus livros vivos, transformando-os em objetos passíveis de atenção, comercialização e consumo.

Categorizado como produto concernente à Literatura de Entretenimento, Twilight alcançou em poucos meses as primeiras posições como livro impresso mais vendido no ano no qual fora lançado em território nacional, em meados de 2008. O sucesso de vendas alcançado por esta obra corresponde a algo indiscutível. Embora seja verdade, ainda hoje "[...] os best-sellers são uma classe de livros [...] menosprezada como sendo composta de objetos de diversão e não estudados como trabalhos de arte literária ou, no mínimo, como trabalho artístico considerável [...]" (ACHER \& JOCKERS, 2017, s/p). Assim preconizam Jodie Archer e Matthew Jockers, estudiosos e autores de $O$ segredo do bestseller: tudo o que você precisa saber para escrever um livro campeão de vendas (2017). 
Muitas minúcias se perdem ao nos desfazermos das possibilidades de análises de fenômenos literários como Crepúsculo (2008), especialmente no que diz respeito à cultura contemporânea, conforme apontam Acher e Jockers (2017). Isto, pois a dinâmica social de consumo e mercado encontra-se fortemente atrelada às relações de cunho cultural.

Embasando-nos nas ponderações de Acher e Jockers (2017, $\mathrm{s} / \mathrm{p})$ em relação àquilo que seus estudos apontam como sendo características proeminentes de livros considerados best-sellers, logo nos tornamos capazes de entender por que a coleção literária de Stephanie Mayer experimentara boom de vendas, crítica e recepção quando lançada ao mercado. Segundo os autores, conflitos movem os enredos apresentados por livros, o que corresponde a aspecto de considerável importância para que uma produção literária venha a se tornar sucesso de adesão e comercialização entre os leitores. De fato, a cada volume da saga podemos acompanhar as problemáticas enfrentadas pelas personagens, as quais se alternam entre os livros, dividem a atuação junto a outras, ou ainda, concedem espaço para que novos protagonistas, coadjuvantes e vilões venham também a ganhar o devido destaque no decorrer da trama literária, tornandose, estes, imprescindíveis à narrativa.

De acordo com Acher e Jockers (2017, s/p), gêneros e temas não se constituem unicamente fatores de relevância para que um livro alcance as melhores posições da lista de mais vendidos. Este tópico nos permite refletir quanto ao fato de que se Twilight trouxesse à tona atmosfera outra, distinta daquela preconizada por Mayer, com outras criaturas ou cenários, por exemplo, sem embargo a história de Edward e Bella poderia deter, se 
não o mesmo, sucesso muito próximo àquele originalmente conquistado $^{8}$. A explicação mais provável a esta possibilidade se encontra na combinação entre fatores, a qual, assim ressaltam os estudiosos, é indispensável à fama de um livro - dentre estes, alguns presentes em Crepúsculo (2008), como a abordagem de ameaças e relações de afeto e intimidade.

Por fim, um livro tido como best-seller não necessariamente corresponde a uma obra de boa qualidade, pontuam Acher e Jockers (2017, s/p), o que não nos surpreende, haja vista que o valor de literariedade não se constitui fator comumente relevante à expressiva parcela de indivíduos a qual irá adquirir este ou aquele livro. Segundo os teóricos, o que na realidade os leitores procuram ao se deleitar por uma obra literária são os reflexos de suas facetas nas personagens apresentadas pelo enredo, além de experienciar emoções diversas, muitas das vezes até então jamais plenamente vivenciadas.

Decorre daí, talvez, a razão que há por detrás da adesão à obra por contingente majoritariamente constituído por jovens indivíduos. Afinal, é exatamente na fase vital relativa à juventude que "[...] as leituras abrem para um novo horizonte e tempos de devaneio que permitem a construção de um mundo interior, um espaço psíquico [...]" (PETIT, 2009, p.32), de acordo com Michèlle Petit, estudiosa à frente da produção teórica A arte de ler: ou como resistir à adversidade (2009). Dificilmente um adolescente, ainda que nascido em continente distinto ou época remota, garota ou garoto, não se identificaria com os impasses familiares, sociais e escolares

8 Contudo, fora devido à abordagem do tema vinculado ao universo vampiresco que esta vertente literária ganhara força e espaço no mercado nos anos 2000. 
que perpassam o romance vivido por Edward e Bella - daí o fato de que tanto o livro quanto o filme lograram sucesso em inúmeros países. Este sentimento universal, o qual conecta milhares de jovens leitores espalhados ao redor do mundo, também se presentifica no cerne do debate sobre o contato destes indivíduos com títulos literários manufaturados em meio à liquidez contemporânea.

A obra A literatura em perigo (2010), cujo autor é o filósofo Tzvetan Todorov, nos expõe à reflexão de questões atinentes à Literatura, concebendo-a como algo mais que "[...] um simples entretenimento, uma distração reservada às pessoas educadas [...]" (TODOROV, 2010, p.23). Para o autor, a manifestação literária permite que cada indivíduo venha a se tornar capaz de melhor responder aos seus potenciais e às suas vocações enquanto seres humanos. $E$ acresce, adiante: "[...] a literatura amplia o nosso universo, incitanos a imaginar outras maneiras de [...] organizá-lo [...]" (TODOROV, 2010, p.23). Embora nos apresente a estas prerrogativas, Todorov (2010, p.24) elenca algumas das inconsistências relativas ao trabalho escolar no campo literário, os quais influenciam diretamente o processo de formação de jovens leitores. Afinal, o contato de aprendizes com a Literatura frequentemente acontece via tópicos de discussões que auxiliam a compreensão, de modo demasiado generalista, da língua mãe em questão.

Logo, entendemos que o famigerado perigo ao qual Todorov (2010, p.9) se refere, inclusive, no título de sua obra, se encontra no fato de que os estudantes não contatam a Literatura mediante a leitura de textos literários, “[...] mas alguma forma de crítica, de teoria ou de história literária [...]" (2010, p.10). O acesso a esta manifestação artística, portanto, ocorre de modo disciplinar 
e institucional, imbuído das tradições há tempos cultivadas e largamente disseminadas no ambiente propiciador do saber.

A despeito dos esforços empreendidos no transcorrer dos últimos anos, observamos a fuga de jovens alunos em relação à Literatura que lhes é imposta nas escolas, sendo - para o desespero de tais instituições - muito bem recepcionados e acolhidos por aquilo que o ensaísta Mario Vargas Llosa (2013, p.31) outrora adjetivou, em clara menção às ficções literárias de viés estritamente comercial, como Literatura light, leve e ligeira.

Contra as expectativas das autoridades escolares, Todorov (2010, p.82) encoraja a leitura de romances como Os Três Mosqueteiros e Harry Potter - aqueles, de acordo com o estudioso, os quais foram considerados com condescendência ou desprezo por críticos e profissionais vinculados ao ramo literário. Talvez a passagem de maior importância presente no posicionamento de Todorov (2010) se refira ao ponto no qual o filósofo reconhece que o acesso a estes livros populares conduziu muitos jovens ao hábito da leitura e também Ihes possibilitou a construção de perspectivas sobre o mundo, cujas "[...] leituras posteriores se encarregarão de tornar mais complexas e nuançadas [...]" (TODOROV, 2010, p.82). Esta citação embasa nosso argumento de que o debate não possui como enfoque a substituição de títulos canônicos por best-sellers no contexto do processo de formação de leitores. Relaciona-se, na realidade, à compreensão de que estes são capazes de atuar como molas propulsoras a outras futuras leituras e Literaturas. Afinal, tal como esclarecido por Peter Hunt em Crítica, teoria e literatura infantil (2010), não sugerimos o início de um movimento anárquico educacional - pautando-nos aqui nos próprios termos utilizados 
pelo autor. Ao apresentarmos ao indivíduo um livro categorizado como clássico, devemos também deixar claro que não há nada intrinsecamente melhor no texto em questão.

Obras contemporâneas aos jovens aos quais aqui nos referimos vieram a se tornar grandes cânones de suas gerações, detentores, cada qual, de específicas singularidades atreladas aos comuns elementos da narrativa literária, entre enredo e personagens, responsáveis, de algum modo, por fazer com que se deleitassem por entre as inúmeras viabilidades da Literatura. Em Leituras: do espaço íntimo ao espaço público (2013), novamente Michèlle Petit, adequadamente embasada a partir da realização de estudos e pesquisas concernentes à sua área de atuação, confirma-nos: "[...] evidentemente, os adolescentes pedem por determinado bestseller e gritam contra qualquer texto que se afasta dos caminhos trilhados [...]" (2013, p.48, grifo da autora). Enganam-se aqueles que creem se configurar tal atitude algo prejudicial. Isto, pois a prática da leitura nesta fase vital possui caráter eclético, já que "[...] os adolescentes aproveitam tudo o que cai em suas mãos, sem pensar em classificações determinadas [...]" (PETIT, 2013, p.48).

Diante disto, o mercado editorial apropria-se de movimentos vários capazes de explorar tal interesse, resultando ainda na realização de outro movimento de igual relevância por parte das diversas mídias modernas - todas cientes de que a prática de leitura não mais deve ser concebida isoladamente e que a nova geração de jovens é capaz de, sozinha, definir e estabelecer os critérios para eleger seus próprios clássicos. 


\section{DE FENÔMENO LITERÁRIO A PRODUTO DA CONVERGÊNCIA MIDIÁTICA}

Certamente, o universo de seres sobrenaturais jamais estivera em evidência tal como ocorrera quando presenciamos o despontar referente ao lançamento do primeiro volume constituinte de The Twilight Saga, promovido em território norte-americano em meados do ano de 2005. Responsável por abordar, dentre outras questões, também acerca das peculiaridades inerentes à classe dos vampiros, Crepúsculo, lançado pela editora Intrínseca em solo nacional apenas três anos mais tarde, viera a desmistificar comuns e pregressos estereótipos de que estas criaturas, presentes no imaginário folclórico e popular, são avessas a elementos como luz e crucifixos, ou que se constituem sedentas, única e exclusivamente, por se alimentar de sangue humano - mas apenas por tais mencionados aspectos.

Os vampiros idealizados por Stephanie Mayer brilham como diamantes quando se expõem à luz solar, bem como em momento algum parecem temer o contato com objetos sagrados. E Edward Cullen, o protagonista vampiro da série, declara todo o seu atemporal e místico amor por uma adolescente humana chamada Isabella Swan - carinhosamente apelidada por amigos e familiares como Bella. O vampiro, anti-herói engendrado com base em clássicos moldes byronianos ${ }^{9}$, é inteligente - perdemos as contas de quantas vezes cursou o Ensino Médio, visto sua centenária existência de dezessete anos de idade -, introspectivo - frustradas são as tentativas de adentrar a mente de Bella - e sedutor - sua aura

9 Esta terminologia alude às personagens retratadas nas obras de Lord Byron (1788 - 1824), influente escritor e poeta britânico atuante durante a fase do Romantismo. 
de frieza e indiferença é responsável por atrair algumas garotas da escola. Além disto, é de origem aristocrática. O estabelecimento de relacionamento amoroso entre ambos os jovens obviamente enfrenta alguns entraves, dentre os mais notáveis, a dificuldade de aceitação por membros da família do casal ou a inquietante desconfiança dos integrantes do tradicional clã dos vampiros Volturi, o que os conduz, ao final, a uma épica batalha.

Cabe ressaltarmos, ainda, a existência de personagens sem as quais o curso da história de amor protagonizada por Edward e Bella não seria o mesmo. Jacob, amigo da garota, descobre-se lobisomem no segundo título da quadrologia, Lua nova (2008). Victoria, por seu turno, apresenta-se proeminente em Eclipse (2009), terceira obra da saga, perseguindo Bella em uma tentativa de extermínio que se apresenta, em seu término, completamente ineficaz. É preciso nos recordarmos, a tempo, da atuação da filha de Edward e Bella, de nome Renesmee, que enquanto espécie de ser de natureza híbrida, fizera-se imprescindível ao inesperado desfecho da história em Amanhecer (2009).

Stephanie Mayer também se aventurara no processo de escrita de outros livros, para além da saga que a elevou a patamares os quais dificilmente um escritor iniciante alcançaria em circunstâncias normais. A exemplo disto, é possível mencionarmos os títulos literários A mediadora (2009) ${ }^{10}$ e A química (2016), ambos lançados no Brasil também pela editora Intrínseca. Reconhecemos que estas obras obtiveram considerável sucesso, contudo, não tanto quanto aquele que seus editores e produtores almejavam lograr não exclusivamente devido a este fato, mas parcialmente por ter 10 À época de sua comercialização, tal obra fora adaptada para as telas do cinema. 
sido sua autora aquela responsável pela concepção do universo vampiresco e sobrenatural referente à Crepúsculo (2008).

Tal acontecimento não acometera apenas a carreira de Mayer. Ao depositarmos atentos olhares à expressão literária produzida a nível mundial, nos tornamos capazes de averiguar que célebres escritores, perpassando por J. K. Rowling e Rick Riordan, respectivamente autores das coleções Harry Potter (Rocco, 2000) e Percy Jackson (Intrínseca, 2010), também se arriscaram a atuar em searas literárias outras e não alçaram voos tão altos ou longínquos como executaram a partir de seus primordiais e memoráveis lançamentos no mercado, decerto responsáveis por fixar, por semanas ininterruptas, seus nomes nos topos das listas de livros impressos mais vendidos ao redor de todo o mundo ${ }^{11}$-fato que corrobora com a teoria de Moretti (2008) já apresentada, a julgar que estes autores arriscaram lançamentos literários externos aos temas cultuados em seus primeiros ciclos.

Em comemoração ao aniversário de dez anos a contar a data de lançamento de Crepúsculo (2008), Stephanie Mayer lançara Vida e morte: crepúsculo reimaginado (Intrínseca, 2018) - no exterior a obra fora comercializada no ano de 2015, chegando ao Brasil apenas em 2018. Trata-se de uma espécie de releitura do livro o qual dera início à trajetória percorrida por seres humanos, vampiros e lobisomens, apresentando-nos à inversão de gêneros entre as personagens Beaufort Swan e Edithy Cullen. A autora também desenvolveu projeto no qual a história de Crepúsculo (2008) é narrada sob a perspectiva do vampiro Edward Cullen, a qual seria

11 Em relação à autora J. K. Rowling, citamos o título Morte súbita (Nova Fronteira, 2012). Referente ao escritor Rick Riordan, podemos mencionar a série Tres navarre (Record, 2011). 
publicada sob o título Midnight sun ${ }^{12}$. Todavia, após o vazamento dos primeiros capítulos da obra no meio virtual, Mayer optou por estagnar sua escrita e disponibilizá-la aos apreciadores da saga apenas em seu website oficial.

Defronte a este panorama o qual gradualmente se delineou frente às melhores expectativas cultivadas por fãs de Twilight, - fenômeno literário de Crepúsculo (2008) experimentara seu ápice não apenas no momento de lançamento do primeiro filme, mas certamente, e sobretudo, a partir da distribuição de títulos sobressalentes à série, tais como $A$ breve segunda vida de Bree Tanner (2010); livros relativos ao universo cinematográfico propiciado pelo enredo, entre estes, Crepúsculo: livro de anotações da diretora (2009) e Crepúsculo: guia oficial ilustrado da série (2011); ou ainda, a apresentação da narrativa sob diferentes modalidades, como é o caso de Crepúsculo: graphic novel (2011), com ilustrações inspiradas nos moldes dos mangás japoneses, sendo lançado em dois volumes.

Também houvera o lançamento de outros títulos literários atrelados à atmosfera vampiresca, no entanto, produzidos ou organizados por outros autores e publicados por outras editoras. Trazemos ao conhecimento obras tais como Crepúsculo e a filosofia: vampiros, vegetarianos e a busca pela imortalidade (Madras, 2010); Stephanie Mayer: a biografia não autorizada da criadora da saga Crepúsculo (Jardim dos Livros, 2010); Vampiros além da saga Crepúsculo: tudo o que você precisa saber sobre os vampiros e Stephanie Mayer não contou em seus romances (Pensamento, 2010); Mordida de amor: o guia não oficial da saga Crepúsculo

12 Do inglês, tradução nossa: Sol da meia-noite. 
(Rai, 2011); entre incontáveis outros. Tais publicações destacam que em torno de um ciclo na Literatura, vários gêneros e nichos são impelidos a se movimentar e, por conseguinte, explorar as temáticas que se encontram em evidência.

Toda esta potencial e singular dinâmica viera a tornar o universo de Twilight talvez a mais aclamada e rentável franquia literária desde a saga britânica Harry Potter (Rocco, 2000), a qual abordou, semelhante à Crepúsculo (2008), atmosfera fantástica na qual seres humanos e mágicos se encontram, ganham vida e escrevem suas próprias histórias, saltando das páginas impressas dos livros para as telas dos cinemas, dos televisores, dos computadores e demais dispositivos eletrônicos. Aliás, atualmente a Literatura se constitui, sobrevive e se transfigura para além do tradicional e até então exclusivo suporte impresso.

A respeito deste específico tópico de discussão, o estudioso Henry Jenkins, autor da obra Cultura da convergência (2008), nos relata que este movimento de convergência contempla transformações as quais são experienciadas pelos modos de produção e, como consequência, também pela maneira por intermédio da qual consumimos as informações a nós cotidianamente apresentadas. Em meio a esta inovadora dinâmica, especialmente de cunho mercadológico, remotas, recentes, alternativas e coorporativas mídias, encontram-se e deleitam-se. Como resultado de suas colisões, cruzamentos e diálogos, conforme assim podemos acrescer, sob a perspectiva do pesquisador, "[...] o poder do produtor de mídia e o poder do consumidor interagem de maneiras imprevisíveis [...]" (JENKINS, 2008, p.30). 
Quanto a isto, Cultura da conexão (2015), da autoria do mesmo teórico, nos apresenta a interessante situação experienciada por produtores e fãs da saga em voga. Durante a edição final do filme Amanhecer - Parte I, houvera o vazamento de algumas imagens na Internet. Diante deste acontecimento, Summit Entertainment, produtora responsável pela adaptação cinematográfica, apelou aos admiradores da franquia que não visualizassem tais fragmentos e não os compartilhassem, a fim de que esta ação infratora deixasse de deter ainda mais força. Jenkins $(2015, \mathrm{~s} / \mathrm{p})$ relata que muitos fãs cooperaram e, por este motivo, reduziram a propagação não autorizada dos vídeos. Ocorrências tais como esta nos conscientiza quanto ao fato de que o formato do sistema cultural em vigência ainda se encontra em fase de transição e extrema fragilidade. Portanto, batalhas coletivas para que haja a definição de ambiente midiático mais ético se fazem pertinentes à atual indústria do entretenimento. Ora, a própria interrupção da escrita de Midnight sun por parte de Stephanie Mayer ratifica tal hipótese, já que a recepção do público pode ter sido, paralelamente, um dos vetores para a sua decisão de manter a obra apenas no ciberespaço.

Atualmente, autores e leitores, ídolos e fãs, interagem e partilham impressões com o auxílio das ferramentas ofertadas por populares redes sociais e plataformas virtuais, como Facebook, Instagram e Twitter. O estabelecimento de diálogos e relacionamentos entre ambas as partes tornara-se algo viável a partir da diária expansão da grande rede de computadores. Se antes expressar admiração por esta ou aquela eloquente personalidade se fazia possível apenas por meio do envio de cartas ou da participação em concursos televisivos, hoje a conexão de fibra 
óptica viabiliza a criação e o estreitamento de laços de amizade, companheirismo e trabalho entre os envolvidos. No contexto de interação virtual encabeçada por fãs de Twilight, é possível mencionarmos a existência de algumas populares comunidades online nas quais entretenimentos diversos são ofertados aos apreciadores; são algumas delas: Foforks, Twilight Brasil, Twilight Moms e Twilighters.

Contágio: por que as coisas pegam (2014), de Jonah Berger, disserta-nos a respeito da relevância do advento das novas tecnologias digitais, enfatizando de que modo o espaço virtual tornara-se responsável pelo impulso relativo à disseminação dos conteúdos em diferentes continentes e para inúmeros indivíduos - "[...] essas tecnologias tornaram mais fácil [...] compartilhar coisas rapidamente com um amplo grupo de pessoas [...]" (BERGER, 2014, p.12). Em consonância a estes preceitos, o autor de Como viver na era digital (2012), Tom Chatfield, posicionase a respeito do espaço de diálogo e interação promovido pela Internet e suas facetas várias, salientando ser este "[...] uma passagem para o lugar onde lazer e trabalhos estão interligados [...]" (CHATFIELD, 2012, p.9).

Influenciadas pela rede cibernética a qual se transfigura em torno de todos os seus navegantes, as empresas atreladas à comercialização de mídias e marcas passam então a se preocupar com a face econômica oriunda da economia afetiva, para além, unicamente, da qualidade das experiências ofertadas. De acordo com Jenkins (2008, p.97), tal ramificação, proveniente do campo de estudos do Marketing, enaltece a necessidade no que se refere à quantificação do desejo, à mensuração das relações e à 
transformação da interação afetiva em commodities. O sentimento transfigura-se, portanto, produto vendável.

Imersos no fenômeno Twilight e devidamente embasados pelo aporte teórico anteriormente elencado, somos capazes de aqui nos recordar dos empreendimentos multimidiáticos - e extremamente rentáveis, diga-se de passagem - vinculados à franquia em destaque, entre estes, a criação de games virtuais não oficiais, encabeçada por admiradores da saga; a composição de faixas musicais exclusivas para o filme, bem como a organização de trilhas sonoras em formato físico e digital; a comercialização de brinquedos e produtos de uso pessoal, tais como vestimentas e artigos congêneres ou objetos para fins decorativos; e, por fim, álbuns de figurinhas, guias e manuais exclusivos, edições especiais de revistas teen, cards colecionáveis e outros materiais expostos em bancas.

Inclinando-se sobre o campo de manifestação literária, Jenkins (2008) acredita que os jovens consumidores, frente à significativa quantidade de produtos os quais se originam de suas obras prediletas, transformam-se em verdadeiros "[...] caçadores e coletores de informações [...]" (JENKINS, 2008, p.169). Expressam inabalável prazer em rastrear os antecedentes relativos às personagens que compõem os enredos literários os quais admiram, ou ainda, às específicas passagens da história em questão, propiciando-Ihes, consequentemente, a realização de conexões entre distintos textos constituintes de uma única franquia. Logo, são idealizadas novas narrativas, as quais concedem trajetórias inimagináveis e diversas aos protagonistas, coadjuvantes, vilões e outras personagens. 
Exemplificamos este fato ao nos reportarmos à elaboração e à partilha de fanfics no ciberespaço. A partir das exaustivas práticas de escrita no ambiente eletrônico, anônimos internautas se aventuram e se divertem como autores de suas próprias histórias, tomando de empréstimo os heróis os quais Ihes fora oportunizado conhecer outrora somente no decorrer das páginas dos livros impressos. Alguns encaram como ocupação profissional, e caso obtenham sucesso na Web, têm seus livros publicados por grandes grupos editoriais ${ }^{13}$.

Entretanto, há jovens escritores os quais não obtiveram acesso a plataformas virtuais de redação e publicação literária, mas ainda sim lograram alcançar expressiva fama a partir daquilo que até então consideravam como esboço de provável bestseller. Como quase namorei Robert Pattinson (Jangada, 2011), de autoria da jovem blogueira Carol Sabar, apresenta-nos à história da adolescente Duda, fã da saga Twilight e que por acaso mantém perfil fake na Internet, por meio do qual se comunica com outros admiradores do universo em voga. Este é o ponto de partida para que as divertidas aventuras da personagem Duda se desenvolvam tendo como foco sua inabalável paixão pelo vampiro Edward Cullen, originário de Crepúsculo (2008) e interpretado no cinema pelo ator Robert Pattinson.

Os frios, úmidos e temidos bosques da cidade norte-americana de Forks, liricamente descritos por Stephanie Mayer em suas obras,

13 A escritora norte-americana E. L. James, autora da trilogia Cinquenta tons de cinza (2011), declarou, em entrevista ao website Estadão, ter sido Crepúsculo (2008) a inspiração para a escrita de suas obras de conteúdo erótico, consideradas best-sellers desta contemporaneidade. Para o acesso a mais informações, sugerimos o seguinte link: https://cultura.estadao.com.br/noticias/literatura,autora-de-cinquenta-tons-de-cinzafala-de-sua-inspiracao-para-criar-o-best-seller,931143 Acesso em 15.Mar.2019. 
foram cenários efetivamente capazes de nos demonstrar que The Twilight Saga mobilizou não somente o mercado de consumo de produtos ou livros impressos, mas de dinamizar, junto a outras importantes obras literárias, de faceta sobrenatural ou não, a interação entre jovens fãs, pretensos a se tornarem promissores escritores e leitores de suas gerações, influenciando positivamente seus pares.

\section{CONSIDERAÇÕES FINAIS}

Talvez o maior legado atinente à saga Crepúsculo (2008) possa ser averiguado ao depositarmos atentos olhares à formação de novos leitores. Desvendados alguns mistérios e sustentáculos relativos ao estrondoso sucesso literário e multimidiático de The Twilight Saga, obtemos embasamento adequado para que possamos refletir sobre o quão relevante se fizeram - e ainda o fazem - estes livros à história da Literatura Juvenil Contemporânea.

Reportando-nos a anteriores passagens, de fato se figura louvável a fama alcançada pelo enredo sobrenatural por intermédio do qual Edward e Bella amadurecem e lutam contra seus próprios medos e incertezas. Em parte banal, tendendo quase ao clichê, este fenômeno literário ressignificou o modo de se produzir, comercializar e refletir a Literatura dedicada ao público jovem, protagonista da atual modernidade. Há dez anos, quando as novas tecnologias ainda caminhavam a sutis e a tímidos passos, Crepúsculo (2008) desde já nos demonstrara sua promissora singularidade diante das viabilidades de se constituir para além de comum produção literária, em temporalidade na qual likes, hashtags e shares ainda não se faziam elementos conhecidos - ou quiçá discutidos em contexto digital. 
Jovens indivíduos encontraram a si próprios e a Literatura a partir de suas imersões por entre as deslumbrantes vegetações dos bosques localizados em Forks ou os campos utilizados como cenários para as épicas batalhas travadas entre seres humanos, vampiros e lobisomens. E estes mesmos jovens também encontraram pares com os quais debater acerca dos poderes desenvolvidos por cada membro da família Cullen ou como poderia ter sido a vida de Bella caso esta escolhesse permanecer distante de Edward, junto a Jacob.

Ainda romantizada, a figura do vampiro moderno, representada na coleção literária por Edward Cullen, seus familiares e seus inimigos, se delineia com base no arquétipo remotamente trazido à luz por Lord Byron - com exceção de que tais seres, na obra de Stephanie Mayer, dirigem Jeeps, Porshes e Volvos blindados e de última geração e ostentam os melhores e mais onerosos aparelhos celulares e relógios de pulso. Não tarde, é preciso evidenciar que Cullen e seus irmãos são estudantes colegiais, cursam Matemática, possuem parceiros de laboratório, preocupam-se com exames e conceitos avaliativos e almoçam diariamente no refeitório de sua escola, segmentados e categorizados em grupos por suas aptidões ou estilos de vida. Portanto, se por um lado o protagonista vampiro em muitas questões se distancia de comuns jovens de quinze ou vinte anos idade, leitores de sua história, em aspectos outros se aproxima e compartilha de êxitos e insucessos enquanto adolescente e estudante por aproximadamente cento e dezessete anos de idade.

A construção destas personagens vampirescas, talvez por não nos apresentar significativas novidades em relação ao modelo historicamente atrelado aos seres de natureza sobrenatural, presentes na Literatura, possibilitou o depósito de perspectivas distintas a este 
nicho literário. Tradicionalmente, afinal, as criaturas em destaque, além de se constituírem vinculadas à atmosfera byroniana, desde sempre estiveram envoltas por corriqueiros enredos demasiado obscuros sem chance alguma para o amanhecer, em vias contrárias à proposta de Mayer. Claramente, The Twilight Saga não ignora a modernidade comum à temporalidade na qual a história se desenvolve, embora verifiquemos a existência de importantes flashbacks históricos dedicados ao caminhar de alguns de seus vampiros.

No que se refere à prática de leitura por jovens indivíduos, decerto, o contato com os produtos literários provenientes de seus próprios tempos, similar àquilo que ocorre com Crepúsculo (2008), será capaz de tornar mais sofisticadas suas experiências frente às habituais exigências pertinentes, em geral, ao currículo escolar e à trajetória vital.

Logo, representantes da identidade cultural do zeitgeist ${ }^{14}$ ou das circunstâncias as quais se encontra sujeita a dinâmica do mercado de consumo, os vampiros ficcionais desta contemporaneidade, seres resultantes da peculiar hibridez característica de tempos líquidos e modernos, interceptados por antigas e novas tecnologias, de líderes de temidos e tradicionais clãs a estudantes colegiais, de Lord Ruthven ${ }^{15}$ a Edward Cullen, também reivindicam um lugar ao sol - ou não; ou apenas espaços nas prateleiras de livros ou nos fóruns de discussão online sediados no ciberespaço - e os têm logrado com êxito.

14 Termo de origem alemã o qual diz respeito ao clima cultural e intelectual a nível mundial. 15 Lord Ruthven é tido como o primeiro vampiro presente na Literatura, podendo ser melhor conhecido a partir da leitura do conto The Vampyre (1819), da autoria de John William Polidori. 


\section{REFERÊNCIAS}

ACHER, Jodie; JOCKERS, Matthew L. (2017). O segredo do best-seller: tudo o quê você precisa saber para escrever um livro campeão de vendas. São Paulo: Astral Cultural. BERGER, Jonah (2014). Contágio: por que as coisas pegam. Rio de Janeiro: Leya. CABOT, Meg (2011). Insaciável. Rio de Janeiro: Record.

CAST, P.C. (2007). House of night. São Paulo: Novo Século.

CHATFIELD, Tom (2012). Como viver na era digital. São Paulo: Objetiva.

CLAIRE, Cassandra (2013). Os instrumentos mortais. Rio de Janeiro: Record.

DUNN-MASCETTI, Manuela (2010). Vampiros além da saga Crepúsculo: tudo o que você precisa saber sobre os vampiros e Stephanie Mayer não contou em seus romances. São Paulo: Pensamento.

HARDWICKE, Catherine (2009). Crepúsculo: livro de anotações da diretora. Rio de Janeiro: Intrínseca.

HOUSEL, Rebecca; WISNEWSKI, J. Jeremy (2010). Crepúsculo e a filosofia: vampiros, vegetarianos e a busca pela imortalidade. São Paulo: Madras Editora. HUNT, Peter (2010). Crítica, teoria e literatura infantil. São Paulo: Cosac Naify. FITZPATRICK, Becca (2011). Hush, hush. Rio de Janeiro: Intrínseca. HARRIS, Charlaine (2009). Morto até o anoitecer. São Paulo: Ediouro. HAUCK, Colleen (2011). A maldição do tigre. São Paulo: Arqueiro. JAMES, E. L (2011). Cinquenta tons de cinza. Rio de Janeiro: Intrínseca. JENKINS, Henry (2011). Cultura da convergência. São Paulo: Aleph. (2015). Cultura da conexão. São Paulo: Aleph.

KATE, Lauren (2010). Fallen. Rio de Janeiro: Record.

LLOSA, Mario Vargas (2013). A civilização do espetáculo: uma radiografia do nosso tempo e da nossa cultura. São Paulo: Objetiva.

MAYER, Stephanie (2008). Crepúsculo. Rio de Janeiro: Intrínseca. (2008). Lua nova. Rio de Janeiro: Intrínseca. (2009). Eclipse. Rio de Janeiro: Intrínseca. (2009). Amanhecer. Rio de Janeiro: Intrínseca. 
(2009). A mediadora. Rio de Janeiro: Intrínseca. (2010). A breve segunda vida de Bree Tanner. Rio de Janeiro: Intrínseca. (2011). Crepúsculo: graphic novel. Rio de Janeiro: Intrínseca. (2011). Crepúsculo: guia oficial ilustrado da série. Rio de Janeiro, Intrínseca. (2016). A química. Rio de Janeiro: Intrínseca.

(2018). Vida e morte: crepúsculo reimaginado. Rio de Janeiro: Intrínseca. MARION, Isaac (2012). Sangue quente. Rio de Janeiro: Leya. MEAD, Richelle (2007). Academia de vampiros. São Paulo: Agir. MORETTI, Franco (2008). A literatura vista de longe. Porto Alegre: Arquipélago Editorial.

PETIT, Michèlle (2009). A arte de ler: ou como resistir à adversidade. Porto Alegre: Editora 34.

(2013). Leituras: do espaço íntimo ao espaço público. Porto Alegre: Editora 34.

RICE, Anne (1976). Crônicas vampirescas. Rio de Janeiro: Rocco. RIODAN, Rick (2010). Percy Jackson. Rio de Janeiro, Intrínseca. (2011). Tres navarre. Rio de Janeiro: Intrínseca.

ROWLING, J. K (2000). Harry Potter. Rio de Janeiro: Rocco. (2012). Morte súbita. Rio de Janeiro: Nova Fronteira.

SABAR, Carol (2011). Como quase namorei Robert Pattinson. São Paulo: Jangada. SHAPIRO, Marc (2010). Stephanie Mayer: a biografia não autorizada da criadora da saga Crepúsculo. São Paulo: Jardim dos Livros.

SMITH, L. J (2009). Diários do vampiro. Rio de Janeiro: Record.

SPENCER, Liv (2011). Mordida de amor: o guia não oficial da saga Crepúsculo. São Paulo: Rai Editora.

TODOROV, Tzvetan (2010). A literatura em perigo. Rio de Janeiro: Difel.

WARD, J. R (2011). Fallen angels. São Paulo: Universo dos Livros.

YOUNG, William P (2008). A cabana. Rio de Janeiro: Sextante. 


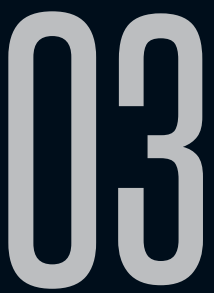

\section{AMBIGUIDADES DO VAMPIRO NA LITERATURA OITOCENTISTA}

Juliana de Souza Topan (Unicamp)

Recebido em 14 mar 2019. Juliana de Souza Topan é Doutoranda em Teoria e Aprovado em 27 jun 2019. História Literária na UNICAMP, Mestre em Educação e professora no IFSP, campus São Paulo Pirituba, onde atua na graduação em Letras, nas áreas de Literaturas em Língua Portuguesa, Literatura Infantil e Literatura Juvenil. É membro do CELTA (Centro de Estudos de Literatura, Teorias do fenômeno religioso e Artes, IEL/UNICAMP) e do LINTEC (Grupo de Pesquisa em Linguagem, Tecnologia e Cultura, IFSP). Áreas de interesse e pesquisa: literatura brasileira; mitologia e literatura; literatura infantil; literatura juvenil; ensino de literatura. Lattes: http://lattes. cnpq.br/3328777524800655. E-mail: juliana.topan@ifsp. edu.br.

Resumo: O vampiro é uma personagem mítica e literária que, nas últimas décadas, esteve presente em obras literárias, televisivas e cinematográficas de grande sucesso de público, como os filmes Drácula de Bram Stoker (1992) e Entrevista com o vampiro (1994), a série televisiva Buffy, a caça-vampiros (1997-2003) e a saga Crepúsculo, de Stephenie Meyer (2005-2008). Analisando narrativas vampirescas contemporâneas, David Roas aponta uma "domesticação" ou "naturalização do monstro", já que vampiros convivem com humanos e se convertem em "mais uma raça ou espécie", entre tantas no mundo. Roas identifica que 
o processo de humanização da figura do vampiro e a atenuação de seus aspectos monstruosos teriam se iniciado com a publicação de Entrevista com o vampiro (1976), de Anne Rice, a partir da caracterização de Louis como um vampiro belo, sensível e culpado por matar pessoas. Entretanto, ao analisar poemas e narrativas do final do século XVIII e do século XIX, o presente artigo pretende explicitar que tal processo se inicia muito antes, na transição da personagem vampiresca do universo mítico para obras literárias. Conclui-se, a partir da análise dos poemas Christabel, de Coleridge (1795) e A noiva de Corinto, de Goethe (1797), do conto A morta amorosa, de T. Gautier (1836), e dos romances Carmilla, a vampira de Karstein, de S. Fanu (1874) e Drácula, de B. Stoker (1897), que, desde o século XVIII, encontra-se uma ambiguidade na caracterização dos vampiros em obras literárias, nas quais se encontra uma alternância entre a descrição humanizada e monstruosa dos vampiros.

Palavras-chave: Vampiros; Imagens vampirescas; Mutações do vampiro; Vampiros no século XIX.

Abstract: The vampire is a mythical and literary character who in the last decades has appeared in literary, television and cinematographic pieces of great success, such as Bram Stoker's Dracula (1992) and Interview with the vampire (1994) movies; the television series Buffy, the vampire slayer (1997-2003); and the Twilight saga, by Stephenie Meyer (20052008). Analyzing contemporary vampiric narratives, David Roas suggests a "monster domestication" or "naturalization", since vampires and humans coexist, and the former turn into "one more race or species" among others in the world. Roas identifies that the humanization process of the vampire's figure and the mitigation of his monstrous' aspects have started with the release of Interview with the vampire (1976), by Anne Rice, since Louis' description as a sensitive and beautiful vampire, who feels guilty of killing people. 
However, analyzing eighteenth and nineteenth centuries poems and narratives, this article seeks to highlight that this process has started early, in the transition of the vampiric character from mythical universe to literary pieces. Considering poems such as Christabel, by Coleridge (1795), and The bride of Corinth, by Goethe (1797); the short story The dead woman in love, by T. Gautier (1836); and novels as Carmilla, the vampire of Karstein, by S. Fanu (1874), and Dracula, by B. Stoker (1897), we conclude that since the eighteenth century, there is an ambiguity in vampires characterization on literary pieces, in which there is an alternation between a humanized and a monstrous vampire description.

Keywords: Vampires; Vampiric Images; Vampiric mutations; Vampires in nineteenth century.

\section{INTRODUÇÃO}

A expressão "as metamorfoses do vampiro", cunhada por Charles Baudelaire como título de um dos poemas de seu famoso livro Les fleurs du mal (1857, p.206) já se tornou um lugar comum na crítica de narrativas vampirescas, sejam literárias ou cinematográficas. Há mais de duzentos anos, o vampiro deixou de estar presente apenas nas crenças e mitos para integrar a literatura da Europa e, posteriormente, de outros continentes, e, nesse processo, inúmeras foram as mudanças observadas na constituição e caracterização deste personagem. É fato notável, ademais, não apenas sua permanência, mas sua importância na cultura do século XX: depois da publicação do romance de Bram Stoker (1897), a figura do vampiro se populariza não apenas na literatura, mas, sobretudo, através do cinema. Além de clássicos como Nosferatu, de W. Murnau (1922), calcula-se que, até meados dos anos 1990, 
foram produzidos uma média de 650 filmes sobre vampiros desde o início do cinema (SCHIMIDT, Apud LECOUTEUX, 2005, p.11).

A prova da vitalidade deste personagem é sua recorrente adaptação em diferentes gêneros narrativos e momentos históricos. Recentemente, vampiros novamente garantiram sucesso de público em livrarias e cinemas, em um ciclo que podemos identificar a partir dos anos 1990 (CLARK, 2005), com o filme Drácula de Bram Stoker, de Francis F. Coppola (1992), a série de romances Os diários do vampiro, de L. J. Smith (1991-1992), o filme Entrevista com o vampiro, de Neil Jordan (1994), a série de TV Buffy, a caça-vampiros (criada por Joss Whedon, exibida nos EUA entre 1997-2003), chegando ao século XXI com a publicação da série Crepúsculo, de Stephenye Meyer (2005-2008). Composta por quatro romances e adaptada para o cinema em cinco filmes, entre 2008 e 2012, a série ficou mundialmente famosa, apresentando aos leitores a história narrada por Isabella Swan (ou simplesmente Bella), uma garota de 17 anos que se apaixona por Edward Cullen, um vampiro que frequenta a mesma escola que ela. A ideia de um vampiro - ser marginal, monstruoso - frequentar uma escola - espaço comum e normativo - causa estranhamento, e isso se configura em uma das inovações da narrativa de Meyer, como veremos a seguir. Embora em Buffy, a caça-vampiros, narrativas sobrenaturais e vampirescas (muitas vezes, com elementos de paródia, que ironizam os clichês das narrativas de terror) já sejam representadas no espaço escolar, por protagonistas adolescentes (CLARK, 2005, p.48-50), a saga de Meyer vai além, já que não reproduz o antagonismo entre vampirosalgozes e humanos-vítimas - não há, sequer, a tradicional figura do (ou da, considerando Buffy) caça-vampiros. 
A saga Crepúsculo chamou a atenção do público e da crítica ao deslocar o vampiro da categoria de antagonista para a de herói, colocando em Edward Cullen uma ética cristã aparentemente rara em vampiros de obras anteriores. Edward não ataca humanos, mas alimenta-se do sangue de animais que caça; não utiliza seus poderes para prejudicar pessoas, mas para protegêlas; e, apaixonado por Isabella Swan, tenta afastá-la, temendo os perigos pelos quais ela passaria caso se relacionasse com ele. Não conseguindo manter-se longe da amada, ele a protege não só de outros vampiros, mas de si próprio, recusando-se a ter relações sexuais com ela até o casamento, o que Lydia Kokkola (2010, p.166) identifica como um reflexo de valores mórmons e do movimento cristão True Love Waits $(T L W)^{1}$ na narrativa. Embora Bella o provoque e deseje consumar o ato sexual, Edward resiste, temendo descontrolar-se e machucá-la com sua força vampírica, ou não resistir e beber seu sangue, transformando-a também em vampira. Em suma, um vampiro não só generoso e altruísta, mas controlado, casto.

Outro aspecto interessante da obra é apresentar vampiros que vivem em família, embora isso não se generalize, pois "são poucos os vampiros que vivem realmente em meio aos seres humanos, a maior parte deles é nômade e caça em grupos de dois ou três" (ULIANO, 2017, p.192). Entretanto, embora sejam uma exceção nesse universo ficcional, os Cullen aparecem, aos olhos da 1 True Love Waits (TLW) pode ser traduzido por "O Verdadeiro Amor Espera", movimento evangélico propagado nos Estados Unidos pela LyfeWay Christian Resources desde o início dos anos 1990. Prega a abstinência sexual entre jovens, incentivando-os a fazer um voto de castidade até entrarem em um "casamento bíblico". A Brigham Young University (BYU), a universidade Mórmon de Utah, onde Meyer realizou seus estudos, requeria que seus estudantes aderissem a um código de honra próximo aos princípios do TLW (KOKKOLA 2011, p.166). 
população de Forks, uma pequena cidade do oeste estadunidense, como uma família comum, apesar dos hábitos reclusos e frequentes saídas para caçadas: os filhos frequentam a escola, Carlisle trabalha no hospital, Esme cuida da casa e dos adolescentes.

Os Cullen saem à luz do dia, moram em uma casa branca, não dormem em caixões, não têm aparência putrefata ou cadavérica, apesar de serem pálidos e frios. Ao contrário, Isabella frequentemente se refere ao cheiro agradável e à beleza incomparável de seu amado. Além disso, em Crepúsculo, vampiros não são criaturas demoníacas (não há qualquer menção de terem sido gerados pelo Diabo ou terem qualquer contato com ele) e, no caso dos Cullen, alguns até acreditam em Deus, como é o caso de Edward e Carlisle, que conserva em seu escritório um crucifixo de madeira renascentista (MEYER, 2009, p.36), que pertencia à sua aldeia natal (lembrança do tempo em que era humano e filho de um pastor protestante).

Ao apresentar vampiros que constituem uma família (no sentido não apenas social, mas afetivo), que interagem com humanos e participam de suas comunidades (em seu nível institucional, inclusive), a saga Crepúsculo traz inovações significativas na representação dos vampiros, muitas delas já analisadas pela crítica. Nesse sentido, uma das contribuições relevantes é a de David Roas, professor da Universidade Autônoma de Barcelona. Com base na análise da referida saga, bem como de outras produções literárias, televisivas e cinematográficas contemporâneas sobre vampiros, Roas afirma que há uma tendência de banalização ou domesticação do monstro nas narrativas contemporâneas, nas quais o vampiro não apenas é "despojado de sua dimensão metafisicamente 
ameaçadora e subversiva", mas também apresenta algo "atrativo e estilizado, frequentemente adolescente e, inclusive, apaixonado" $(2014, \text { p.110 })^{2}$.

Para Roas, o "vampiro naturalizado", que se constitui como uma "raça ou espécie a mais entre as que povoam o mundo" (2012, p.451) - daí a possibilidade de integração com a espécie humana tem em Edward Cullen, pelas características acima descritas, sua figura exemplar. O crítico espanhol, porém, identifica a figura do "vampiro humanizado", antes que a do vampiro domesticado ou naturalizado apareça na cultura contemporânea. Segundo Roas, a atenuação dos traços monstruosos e a ênfase nos traços humanos se inicia com as obras da romancista americana Anne Rice e com a já referida adaptação cinematográfica do romance Drácula, de Bram Stoker, por Francis Copolla.

No primeiro caso, o romance Entrevista com o vampiro (1976) coloca em cena Louis, um vampiro sensível, que tem crises de consciência em matar humanos para sobreviver, que Roas descreve como "um depressivo existencialista" (2014, p.113) ou "o primeiro vampiro existencialista da história" (2012, p.446). Salma Ferraz (2017, p.15/16), professora da Universidade Federal de Santa Catarina, também postula a "humanização" de Loius, descrevendo-o como um vampiro "atormentando pela sua essência", que "não consegue se divorciar de vez de sua natureza humana e sensível". Em outras palavras, Ferraz (2017, p.16) ressalta em Louis a figura de um "vampiro que não deu certo", ou seja, que nunca deixou de ser humano, que nunca se transformou completamente em monstro.

2 Tradução nossa. No original: “(...) no sólo se le desposee de sua dimensión metafísicamente amenazadora y subversiva, sino que encima se le representa atractivo y estilizado, a menudo como adolescente y, incluso, enamorado". 
No segundo caso, o filme de Copolla constrói uma justificativa (inexistente no romance) para a ida de Drácula a Londres: ao ver um retrato de Mina Murray, Drácula reconhece a reencarnação de sua amada, que se suicidara há séculos (por acreditar que ele tinha morrido em uma batalha). Assim, ele atravessa oceanos e luta contra todos para reencontrá-la, convertendo-se em um "romântico apaixonado" (ROAS, 2014, p.113), bem diferente do monstro criado por Stoker. A narrativa, portanto, "deixa de ser um romance de terror para passar a ser uma história de amor" (LUCENA, 2010, Apud ROAS, 2012, p.449). A imagem de Drácula apresentada por Coppola tornou-se tão difundida que, inclusive, alguns autores passam a considerar o personagem do romance (e não apenas o do filme) um "herói romântico", como é o caso de Lynn S. Clark (2005, p.52), que, descrevendo o vampiro Angel (da série Buffy, a caça-vampiros), afirma que "ele é um herói trágico, falho e romântico, com ecos do Drácula de Stoker"”3.

Entretanto, em uma leitura atenta de poemas e narrativas vampirescas do final do século XVIII e, principalmente, do século XIX, é possível perceber que esse processo de atenuação dos traços monstruosos do vampiro, sua humanização e sua caracterização "estilizada" - atrativa, sedutora e até romântica - se inicia bem antes das narrativas de Rice e Copolla, mas remonta à transição da personagem do vampiro da narrativa mítica para a narrativa literária, como doravante pretendo demonstrar.

\section{VAMPIROS MONSTRUOSOS}

Para uma compreensão exata do que Roas chama de "banalização do monstro", é necessário remontar à origem do 3 Tradução nossa. No original: "He is a tragic, flawed romantic hero, with echoes of Stoker's Dracula (...)". 
vampiro, personagem que, antes de sua inserção na literatura, pertence à esfera do mito. Segundo Lecouteux (2005), o mito vampiresco está relacionado ao temor dos mortos, especialmente à possibilidade de que, por condições incomuns de sua morte, ou por algum descuido dos vivos nos rituais fúnebres, aqueles pudessem voltar para atormentar e matar seus amigos e entes queridos, ou até mesmo toda a comunidade a que pertenciam.

Em seu livro Totem e tabu (2012), Freud analisa tabus referentes aos contatos com os mortos em sociedades tribais e conclui que o temor de evocar ou de estabelecer contato com uma pessoa morta relaciona-se não apenas com o "natural horror pelo cadáver e pelas mudanças que logo nele se observam", mas também com o medo da "presença e o retorno do espírito do morto", de sua alma "transformada em demônio", para o qual realizam "bom número de cerimônias a fim de mantê-lo distante" (2012, p.34). Citando Rudolf Kleinpaul (1898), Freud (2012, p.35) afirma que: "originalmente (...) todos os mortos eram vampiros, todos tinham um rancor aos vivos e cuidavam de molestá-los e roubar-lhes a vida" e que, posteriormente, a "malevolência dos mortos limitava-se às categorias a que se tinha de reconhecer um direito particular ao rancor" (p.35), ou seja, aqueles cuja vida e/ou morte se dava em condições consideradas anormais, isto é, fora das normas da natureza, da sociedade ou da moralidade. Assim, os que não recebiam os ritos fúnebres adequados, os que morriam precoce e subitamente (especialmente suicidas e assassinados), deixando tarefas inacabadas, conflitos mal resolvidos, promessas não cumpridas; ou os que transgrediam a moral em vida, todos "os marginais, os sacrílegos, os ciumentos, os que foram maltratados em vida e sentem vontade de se vingar" 
(LECOUTEUX, 2005, p.41-42), podiam se tornar mortos malditos, recusados pelo além-túmulo, impedidos de concluir o "transpasse', no sentido etimológico do termo, ou seja, passagem para o outro lado" (LECOUTEUX, 2005, p.40).

Dessa forma, o temor dos mortos que está relacionado ao mito do vampiro se reafirma em sua condição de cadáver que permanece, isto é, que não se decompõe, não desaparece, configurando-se em presença física, portanto impossível de ser ignorada, da morte entre os vivos. Nesse sentido, torna-se um "significante", segundo o psicanalista Max Kohn:

De uma fronteira mais ou menos porosa ou estanque entre os vivos e os mortos, sem suturar a circulação entre os dois. (...) O vampiro concentra e canaliza nele, como poder, figura e imagem também, tudo o que há de indeterminação em nós quanto à distinção entre a vida e a morte, todo um vazio entre a vida e a morte. (2012, p.303)

Assim, nas crenças de povos do leste europeu, em que se basearam as primeiras publicações literárias sobre a figura do vampiro, este era um monstro "em um sentido físico, porque mata os seres humanos para se alimentar deles (...) e em um sentido metafísico, porque é um ser impossível, alguém que retorna do túmulo em outra forma de existência" (ROAS, 2012, p.442). Um ser que retorna da morte em seu próprio corpo, para atormentar os vivos e matá-los - essa simples caracterização, proveniente dos mitos do leste europeu, prevalecia nas primeiras narrativas escritas sobre vampiros, que não eram, propriamente, literárias.

De fato, os primeiros textos sobre vampiros que se difundiram na Europa eram relatórios de autoridades, seguidos por artigos e 
dissertações de teólogos e filósofos. Embora possa parecer bizarra a ideia de um tema pertencente à esfera do sobrenatural mover as preocupações de militares, médicos e acadêmicos, tais relatos resultaram de investigações feitas em algumas vilas e cidades do leste europeu, onde a mortandade de pessoas devido ao suposto ataque de vampiros começou a chamar a atenção de autoridades. Um dos casos mais famosos ocorreu na cidade de Medvegia, na Sérvia, em 1731, para onde uma comissão científica, liderada pelo cirurgião do Regimento de Campo da Infantaria Austríaca, Johannes Fluchinger, dirigiu-se a fim de investigar a morte de 17 pessoas, em decorrência de supostos ataques de um morto-vivo, Arnold Paole (o processo judicial de exumação se encontra reproduzido em LECOUTEUX, 2005, p.179-184).

Fluchinger redigiu um relatório, apresentado ao imperador em 1732, no qual confirmava a existência dos vampiros; publicado no mesmo ano em Belgrado e em Berlim, pela Sociedade Real Prussiana de Ciências, foi reproduzido em obra intitulada Visum et Repertum, que circulou pelo continente europeu, gerou impacto e levou padres, teólogos e filósofos a escreverem sobre vampiros (LECOUTEUX, 2005, p.13; SILVA, Apud COSTA, 2010, p.21-23). Um dos mais relevantes foi Dom Augustin Calmet, que publicou Traités sur les apparitions des anges, des démons et des esprits, et sur les revenants, et vampires de Hongrie, de Moravie, et etc em 1751, em dois volumes. No segundo, o sacerdote e acadêmico francês compila todas as principais publicações sobre vampiros até a metade do século XVIII, analisando-as a partir dos dogmas católicos.

Os relatos compilados por D. Augustin Calmet apresentam o vampiro como um revenant en corps, isto é, uma criatura sobrenatural 
que volta da morte em seu próprio corpo. Assim Calmet define o vampiro, no primeiro capítulo do segundo volume de sua obra:

São os homens mortos desde um tempo considerável, às vezes mais às vezes menos longo, que saem de seus túmulos e vêm inquietar os vivos, sugam-Ihes o sangue, aparecem-Ihes, fazem barulho à suas portas e em suas casas, e enfim causa-Ihes frequentemente a morte. Dá-se a eles o nome de Vampiros ou de Oupires, que significa, diz-se, em Esloveno, um sanguessuga ${ }^{4}$. (1751, p.2)

Nesta definição, o autor resume características que aparecerão em relatos, provenientes de vários países, sobre vampiros. Nota-se, ao longo dos relatos, que o corpo que se levanta do túmulo, aparece aos vivos, importuna-lhes, suga-Ihes o sangue e causa-lhes a morte é visto como uma aberração, uma criatura maldita e perigosa, que é preciso não apenas eliminar, mas garantir que tal eliminação seja absoluta e irreversível, através da decapitação e queima do corpo. Tais relatos reproduzem a imagem do vampiro no folclore do leste europeu: um cadáver que se levanta, que anda, que persegue homens e animais para exclusivamente sugar-Ihes o sangue (SILVA, 2010, p.11), cujos aspectos cadavéricos são assustadores ou repugnantes:

Quando foram retirados da terra, eles [os cadáveres] pareciam vermelhos, tendo os membros flexíveis e maleáveis, sem vermes e sem podridão, mas não sem um muito grande fedor ${ }^{5}$. (CALMET, 1751, p.35)

4 Tradução nossa. No original: “(...) sont des hommes morts depuis un temps considérable, quelquefois plus quelquefois moins long, qui sortent de leurs tombeaux \& viennent inquiéter les vivans, leur sucent le sang, leur apparoissent, font le tintamare à leurs portes \& dans leurs maisons, \& enfin leur causent souvent la mort. On leur donne le nom de Vampires ou d'Oupires, qui signifie, dit-on, en Esclavon une sang-sue".

5 Tradução nossa. No original: "(...) quand on les a tirés de terre, ils ont paru vermeils, ayant les membres souples \& maniables, sans vers \& sans pourriture; mais non sans une très-grande puanteur". 
Eles aparecem desde o meio dia até a meia noite, e vêm sugar o sangue dos homens e dos animais vivos em tão grande abundância, que às vezes ele Ihes sai pela boca, pelo nariz e principalmente pelas orelhas, e que às vezes o cadáver nada no seu sangue, derramado sobre o seu caixão. Este revivido ou Oupire saído de seu túmulo, ou um Demônio sob sua figura, vai à noite beijar e apertar violentamente seus próximos e seus amigos, e lhes suga o sangue, até enfraquecê-los, extenuá-los e Ihes causar enfim a morte ${ }^{6}$. (CALMET, 1751, p.60)

Tal imagem monstruosa, física e metafisicamente, como menciona Roas, parece muito distante dos Cullen, vampiros cuja beleza é comparada a modelos de uma revista de moda, ou à de um anjo:

E ainda, eles eram todos totalmente parecidos. Cada um deles era pálido como gesso, os mais pálidos dos estudantes que viviam nessa cidade sem sol. (...) seus narizes, todas as suas feições eram corretas, perfeitas, angulares.

Mas não era por tudo isso que eu não conseguia desviar o olhar.

Eu olhava porque os rostos deles, tão diferentes, tão parecidos, eram devastadoramente, inumanamente bonitos. Eram rostos que você nunca espera ver exceto talvez nas páginas embelezadas de uma revista de moda. Ou pintadas por um velho mestre como o rosto de um anjo. Era difícil decidir quem era o mais bonito7. (MEYER, 2008, p.16-17)

6 Tradução nossa. No original: "Ils aparoissent depuis midi jusqu'a minuit, \& viennent sucer le sang des hommes et des animaux vivans en si grand abondance, que quelquefois il leur sort par la bouche, par le nez, \& principalement par les oreilles, \& que quelquefois le cadavre nage dans son sang répandu dans son cercueil. Ce rédivive ou Oupire sorti de son tombeau, ou un Démon sou sa figure, va la nuit embrasser \& serrer violemment ses proches et ses amis, \& leur suce le sang, jusqu'à les effoiblir, les exténuer \& leur causer enfin la mort".

7 Tradução nossa. No original: "And yet, they were all exactly alike. Every one of them was chalky pale, the palest of all the students living in this sunless town. (...) their noses, 
A descrição vampiresca de Meyer data do início do século XXI; porém, muito antes disto, já no século XVIII, encontramos, na literatura, uma descrição atraente da figura do vampiro, como veremos a seguir.

\section{MONSTRO MÍTICO E PERSONAGEM LITERÁRIA}

Depois da repercussão das obras jurídicas e teológicas acima citadas, a figura do vampiro começa a aparecer em textos literários, primeiro, na poesia, em meados do século XVIII, inclusive na obra de poetas renomados, como Goethe, que publica "A noiva de Corinto" em 1797. A partir do século XIX, aparece, pela primeira vez na prosa literária, em "O vampiro", conto de Polidori publicado em 1819 na New Montly Magazine, seguido pelo folhetim de James M. Rymer, Varney, the vampire - the feast of blood (1847, considerado o primeiro romance sobre o tema), a novela Carmilla, a vampira de Karnstein, do irlandês Sheridan Le Fanu (1872) e, enfim, o famoso Drácula, do irlandês Bram Stoker (1897). Embora os dados revelem uma predominância do tema em textos de língua inglesa, não se pode deixar de lado as importantes obras dos franceses Théophile Gautier, La morte amoureuse, de 1836, e Lautréamont, Les chants de Maldoror, de 1868-69.

Já a partir da análise dos primeiros poemas que abordam a temática vampiresca, é possível perceber que, à figura monstruosa do vampiro, agregam-se aspectos atraentes e sedutores. No poema

all their features, were straight, perfect, angular.

But all this is not why I couldn't look away.

I stared because their faces, so different, so similar, were all devastatingly, inhumanly beautiful. They were faces you never expected to see except pehaps on the airbrushed pages of a fashion magazine. Or painted by an old master as the face of an angel. It was hard to decide who was the most beautiful (...)". 
de Goethe, "A noiva de Corinto" (baseado no folclore grego e na narrativa de Flégon de Trales (século II d. C.), uma jovem surge em uma atmosfera noturna, oferecendo-se a um hóspede - era a falecida filha dos donos da casa. Há vários indícios de que se trata de uma vampira: ela é "clara como a neve, mas fria", "não Ihe pulsa o coração", e aspira "a todo sangue que tem (...) / sedenta, a debelar gente jovem" (GOETHE, Apud COSTA, 2010, p.231-233). Entretanto, sua aparência não é repugnante, pois desperta o desejo do hóspede, que Ihe implora seu amor, "mesmo que tu venhas da tumba". Ela resiste, a princípio, mas depois cede aos apelos do moço:

Selando em êxtase o amor,

Lágrimas ao desejo se mesclam;

Suga-Ihe ela à boca o calor,

Presos um ao outro se infundem.

(...)

Um singular gemido e bulício.

Em pleno alvoroço

A moça e o moço

Indícios de amor em balbucio (GOETHE, Apud COSTA, 2010, p.231).

Ao analisarmos "O vampiro", de Polidori (1818), primeiro texto literário em prosa a abordar a temática vampiresca, a imagem de Lord Ruthven é de um nobre excêntrico que fascina a sociedade londrina, também distante da descrição do morto-vivo repugnante encontrada nos relatos compilados por Calmet:

Por suas peculiaridades, o nobre era convidado a frequentar todas as casas; todos desejavam vê- 
lo, e os adeptos da diversão intensa, e que agora sentiam o peso do tédio, ficavam satisfeitos diante da oportunidade de entretenimento. Apesar do tom mortiço de seu rosto, que jamais adquiria um matiz mais quente, fosse pelo rubor da modéstia ou pela forte emoção da paixão, talvez por suas feições e seu perfil serem belos, muitas mulheres ávidas por notoriedade tentavam atrair sua atenção. (POLIDORI, Apud COSTA, 2010, p.51 - grifos meus)

Se analisarmos as imagens do vampiro nos textos acima descritos, considerando que se trata dos primeiros textos literários europeus a apresentarem esta criatura (antes circunscrita apenas à esfera dos relatos orais da tradição popular ou dos textos jurídicos e teológicos antes citados), é possível perceber uma atenuação, mas não eliminação, de suas características repugnantes em sua transição do mito à literatura. Em outras palavras, o vampiro literário não deixa de ser um monstro que suga o sangue de humanos e os mata, mas deixa de sê-lo exclusivamente para adquirir características humanas. Essa ambiguidade entre o monstruoso e o humano se tornará ainda mais evidente na análise de três importantes narrativas do século XIX: La morte amoureuse, de Gautier, Carmilla, de Fanu e Drácula, de Stoker.

\section{AMBIGUIDADE VAMPÍRICA}

La morte amoureuse, traduzida no Brasil como A morta amorosa, é uma narrativa em 1a pessoa, em que Romualdo, um padre, conta a história de uma vida dupla: apaixonado por Clarimunda, uma cortesã que se revelará, depois, uma vampira, torna-se seu amante, vivendo com ela em um palácio, em Veneza. Porém, quando il signor Romualdo adormece, ele acorda para sua vida de padre, na 
qual, quando dorme e sonha, volta à sua vida cortesã. Confuso, ele não sabe mais distinguir o que seria sonho e o que seria realidade.

Romualdo vê Clarimunda pela primeira vez na cerimônia de sua ordenação e é capturado por sua beleza, que o leva à perdição (a tradicional tópica da beleza abissal); neste sentido, a descrição da mulher oscila entre aspectos divinos e demoníacos:

A encantadora criatura se destacava sobre este fundo de sombra como uma revelação angelical. Parecia iluminada por si mesma; mais parecia emanar a luz do que recebê-la. (...)

Ela era alta, com o tamanho e o porte de uma deusa. (...) Que olhos!... com um relâmpago, eles decidiam o destino de um homem, tinham uma vida, uma limpidez, um ardor, uma umidade brilhante que jamais vi em olho humano. (...) Não sei se a chama que os iluminava era do céu ou do inferno, mas com certeza vinha de um e de outro. Esta mulher era um anjo ou um demônio, talvez ambos - certamente não saiu da costela de Eva, a mãe comum. (GAUTIER, Apud COSTA, 2010, p.123-124)

A associação da beleza e sedução de Clarimunda à tentação demoníaca se torna mais explícita nas falas do Abade Serapião: "Durante muito tempo correram histórias muito estranhas sobre essa Clarimunda... todos os seus amantes terminaram de maneira miserável ou violenta. Diziam que era uma vampira, mas para mim era Belzebu em pessoa!" (GAUTIER, Apud COSTA, 2010, p.143).

É também na fala do Abade que se explicita a condição vampiresca de Clarimunda, reforçada pelo comentário de que a pedra do seu túmulo deveria ser reforçada, pois "não é a primeira vez que ela morre" (GAUTIER, Apud COSTA, 2010, p.144). Na fala 
da própria personagem se encontra a definição do vampiro como um revenant em corps, um morto-vivo que volta ao seu próprio corpo: "O quanto sofreu minha alma, que volta a este mundo pelo poder da vontade, para reencontrar seu corpo e nele se instalar!" (GAUTIER, Apud COSTA, 2010, p.145).

Depois de morta, Clarimunda aparece para Romualdo durante o seu sono (conforme inúmeras descrições nos relatos compilados por Calmet; cena que se repetirá em narrativas posteriores, como Carmilla e Drácula), mas nem a aparência dela lhe é repugnante, nem lhe parece demoníaca:

Envolta naquele tecido fino que traía todos os contornos do seu corpo, ela mais parecia uma estátua de mármore de banhista antiga do que mulher dotada de vida. Morta ou viva, estátua ou mulher, sombra ou corpo, sua beleza era sempre a mesma. (...)

Apesar de tudo o que eu já vira, ainda não consigo acreditar que fosse um demônio, pelo menos, não parecia um demônio, ou jamais Satã escondeu melhor suas garras e cornos. Estava pousada sobre os calcanhares e se mantinha à beira do meu leito em uma posição cheia de graça e abandono. (GAUTIER, Apud COSTA, 2010, p.145-146)

O apelo sexual de Clarimunda também é explicitamente colocado pelo narrador:

Eu a amava perdidamente. Ter Clarimunda era ter vinte amantes, tanto ela era móvel, versátil e diferente de si mesma... era um verdadeiro camaleão! Clarimunda fazia qualquer um cometer com ela a infidelidade que teria cometido com outras, assumindo completamente a personalidade, 
o comportamento e o gênero de beleza feminina que aparentemente te agradasse. (GAUTIER, Apud COSTA, 2010, p.151)

Se o amor e o desejo fazem com que Romualdo veja Clarimunda como humana e mulher, um episódio revela sua condição de vampira, quando ele se corta e seu sangue desperta a sede de sua amada:

Seus olhos se iluminaram, sua fisionomia tinha uma expressão de alegria feroz e selvagem como eu jamais vira. Saltou da cama com uma agilidade animal, uma agilidade de macaco ou de gato e se precipitou sobre o ferimento, que começou a sugar com indizível volúpia. Engolia o sangue em pequenos goles, lenta e preciosamente, como um gourmet um vinho de Xerez ou de Siracusa, os olhos semicerrados; as pupilas verdes se tornaram oblongas, em vez de redondas. (GAUTIER, Apud COSTA, 2010, p.152-153 - grifos meus)

Chama a atenção os termos, destacados em negrito, que aproximam Clarimunda de uma condição de animalidade, associada à imagem do vampiro monstruoso. Mas, na sequência, o narrador descobre que Clarimunda alimentava-se dele todos os dias, dopando-o e, durante o sono, bebendo-lhe o sangue. A cena, porém, difere bastante da transcrita acima:

Ao certificar-se de que eu dormia, descobriu o meu braço, tirou um alfinete de ouro dos cabelos e começou a sussurrar:

- Uma gota, apenas uma gotinha vermelha, um rubi na ponta da minha agulha! Se ainda me amas, não posso morrer... Ah! Pobre amor! Vou beber teu lindo sangue de uma cor púrpura tão brilhante. Dorme, meu único benzinho... dorme, meu deus, minha criança, não te farei mal... tomarei da tua vida 
apenas o necessário para não extinguir a minha... Se eu não te amasse tanto, poderia decidir ter outros amantes cujas veias eu secaria... mas depois de te conhecer, tenho horror a todos os outros... Ah! Que braço lindo! Como é roliço! Como é branco! Eu jamais ousaria picar esta linda veia azul...

Dizendo isto, ela chorou e eu sentia suas lágrimas choverem no meu braço, que ela tinha nas mãos. Afinal, ela tomou a decisão, deu uma picadinha com a agulha e começou a sugar o sangue que escorreu. Embora tenha bebido só umas gotas, 0 receio de me deixar esgotado se apoderou dela e, com cuidado, envolveu-me o braço com um pequeno curativo, depois de haver esfregado na ferida um unguento que a cicatrizou de imediato. (GAUTIER, Apud COSTA, 2010, p.154)

A cena acima difere absolutamente da postura animalesca observada na anterior: Clarimunda declara seu amor e fidelidade a Romualdo, sentindo-se culpada por feri-lo para tomar seu sangue - o que a leva às lágrimas; tem receio de extenuá-lo e bebe apenas algumas gotas, curando-Ihe depois a ferida. A comparação das duas cenas evidencia a ambiguidade antes postulada, alternância entre uma imagem monstruosa e uma imagem humana do vampiro, embora, ao longo do conto, prevaleça à imagem de Clarimunda como bela, atraente, sedutora e amorosa.

A imagem da beleza e da atração também aparecem em Carmilla, agora associadas também à repulsa, ambiguidade explicitada pela própria narradora da novela de Fanu, Laura (FANU, 2010, p.62), que mora com seu pai em um castelo isolado na Estíria. No início da narrativa, eles presenciam um acidente com uma carruagem, na qual se encontravam uma mulher e sua jovem filha. 
O fato, aparentemente banal, torna-se insólito diante da urgência da mãe em seguir viagem, apesar do estado de saúde aparentemente perturbado da moça; e mais ainda pelo fato daquela, sem revelar sua identidade ou propósitos, pedir ao pai de Laura que abrigue e tome conta de sua filha. Esta é ninguém menos que Carmilla, que, ao final do romance, será identificada como Mircalla, a condessa do vilarejo abandonado de Karnstein (vizinho ao castelo), nascida em 1698 e morta há mais de um século, mas que retornara ao seu corpo como vampira.

O primeiro encontro entre Carmilla e Laura, de fato, já se tinha dado na infância da narradora, em que, numa noite, ela tem a visão de uma mulher em seu quarto, que se aproxima de sua cama e deita-se com ela. Indecisa sobre se teria sonhado ou vivido alguma espécie de transe, Laura tem muito medo e guarda a lembrança do rosto desta mulher por anos, e reconhece-o em Carmilla, que, surpreendentemente, relata-lhe que também reconhecia o seu rosto, pois sonhara com Laura em sua infância. Estabelece-se, neste episódio inicial, a ideia de uma relação entre as duas jovens que antecede o encontro físico, ou de predestinação, explicitada por Carmilla:

sinto como se nos conhecêssemos há doze anos, e sinto que já tenho direito a compartilhar a sua intimidade; em todo caso, parece que fomos destinadas, desde a tenra infância, a sermos amigas. Pergunto-me se você se sente tão estranhamente atraída por mim como eu por você. (FANU, 2010, p.62).

Se Carmilla já declara sua atração e interesse por Laura, este episódio também justifica, para esta, sua atração por Carmilla. Vale 
lembrar que a aparição de uma hóspede inusitada, no meio da noite, e que exerce atração sobre uma jovem pura e ingênua é tema do poema "Christabel", de Coleridge, escrito em 1795 e publicado em 1816. Neste, a jovem Christabel, filha de Sir Leoline, passeia nos arredores do castelo durante a noite, onde encontra uma "formosa senhorita/ Vestida em brancas sedas ao luar". O sentimento de terror pela estranha aparição se mistura à admiração de sua beleza: "Penso comigo, que visão mais terrível,/ Dar ali com uma donzela de tão formosa - / De uma beleza sem igual!" (COLERIDGE, Apud COSTA, 2010, p.239). A moça se identifica como Geraldine, de nobre linhagem; e, tendo sido capturada e depois abandonada por cinco soldados, pede ajuda e pouso a Christabel, que, fascinada, acolhe a moça e a leva a seu quarto.

Assim também Laura afirma ter ficado "fascinada" por Carmilla, "sob os mais diversos aspectos", e a descreve como "extremamente graciosa", de "pele saudável e viçosa; traços delicados e belamente delineados", os olhos, "grandes, escuros e brilhantes" e cabelos "maravilhosos", "tão fartos e tão sedosos" (FANU, 2010, p.65), em nada, portanto, lembrando uma aparência cadavérica ou monstruosa. Tal fascinação se converte em sensações contraditórias ao contato físico de Carmilla (quando esta pega-lhe a mão ou a abraça longamente) e, neste sentido, as descrições não deixam dúvida sobre a atração sexual ${ }^{8}$ entre as duas jovens:

8 Também presente em "Christabel", a relação sexual entre as jovens é sugerida nos versos: "Disse Christabel, que seja assim então!/ E como lhe foi pedido, ela o fez./ Seu belo corpo ela logo despiu,/ E então se deitou em sua perfeição. // (...) Ela se ergueu, apoiada em seu cotovelo,/ Para observar a donzela Geraldine. // Abaixo do lustre a dama se curvou,/ E lentamente seus olhos se viraram;/ E então fazendo cessar a respiração,/ Como alguém que treme, ela desfez/ A fita que trazia logo abaixo do colo:/ Seu vestido de seda, e a anágua,/ Caíram a seus pés, e inteira à mostra,/ Oh! Seu peito e suas costelas -/ Visão de sonho, não há palavras para ela (...) // No entanto, Geraldine não falava,/ Tampouco se mexia - Oh! Que olhar frio!/ (...) Ela se deitou ao lado da Virgem! - / E tomando-a em seus braços,/ Ah, Meu Deus!/ E com a voz baixa e os olhos cheios/ 
Aquelas sensações misteriosas me desagradavam. Eu sentia uma excitação estranha e perturbadora, por vezes, prazerosa, mesclada com uma vaga sensação de medo e certa aversão. (...) eu tinha consciência de um afeto que se transformava em veneração - e também de um repúdio.

Nessas ocasiões ela enrubescia levemente, contemplando meu rosto com um olhar lânguido e tórrido, e ofegando tanto que o vestido chegava a ondular. Parecia um ardor de amante; sentiame encabulada; aquilo era, ao mesmo tempo, detestável e irresistível; com os olhos cheios de desejo, ela me puxava para si, e seus lábios quentes cobriam-me de beijos as faces; ela sussurrava, quase soluçando: "És minha, serás minha; tu e eu seremos para sempre uma só". (FANU, 2010, p.68)

Embora Laura se refira aos abraços tórridos de Carmilla como "ridículos" e apresente claramente um sentimento desagradável nestes momentos de assédio, relata que sua energia "parecia se esvair" e que as palavras de Carmilla "entorpeciam minha resistência, levando-me a um estado de transe, do qual eu só me recuperava quando ela baixava os olhos" (FANU, 2010, p.67). Evidencia-se, neste trecho, além do poder de atração, o poder do vampiro de minimizar a resistência das vítimas com seu olhar, conservando-as sob um estado de transe, o que também aparecerá no Drácula, de Stoker.

Entretanto, ao longo da narrativa, Laura não se refere a isto como poderes vampíricos, uma vez que, apresentando gradativamente sua visão dos fatos enquanto jovem, considera-os características singulares, estranhas, que Ihe sugeriam (e sugerem ao leitor) que senhora de tuas palavras, Christabel!" (COLERIDGE, Apud COSTA, 2010, p.245-246) 
Carmilla não é um ser comum. Aos poucos, as sugestões de que se trata de um ser sobrenatural, ligado ao demoníaco, vão se tornando mais evidentes, com mudanças significativas na descrição da personagem - como ocorre no capítulo IV, no qual, durante uma caminhada, as jovens se deparam com um enterro, e os cantos fúnebres religiosos deixam Carmilla agressiva e com evidente malestar físico:

Sua fisionomia alterou-se de tal maneira que fiquei alarmada e, por um instante, cheia de pavor. 0 semblante se tornou escuro, e depois terrivelmente lívido; seus dentes e punhos se cerravam, enquanto ela franzia o cenho e apertava os lábios, olhando fixamente para o chão, fitando os próprios pés, e tremendo descontroladamente, como quem sofre de malária. (FANU, 2010, p.72)

Carmilla também nunca tinha sido vista rezando: pela manhã, sempre descia de seu quarto depois que a família já fizera suas orações matinais, e à noite, "jamais deixava o salão de estar para participar de nossas breves preces no vestíbulo" (FANU, 2010, p.87).

Outro indício do vampirismo monstruoso de Carmilla é o surto de mortes que se inicia depois de sua chegada, mortes de pessoas aparentemente saudáveis por causas desconhecidas, mas com uma característica comum: quando deitadas, sentiam que alguma coisa as tinha agarrado pelo pescoço, quase estrangulando-as, e, depois de alguns dias de fraqueza extrema, faleciam (FANU, 2010, p.71, 74-75). Um andarilho que passa pelo castelo oferece às jovens "amuleto contra o oupire": "Estão morrendo por causa dele a torto e a direito, e tenho aqui um amuleto infalível; basta prendê-lo ao travesseiro". Os amuletos, que eram "longas tiras de pergaminho, 
contendo códigos e diagramas cabalísticos" (FANU, 2010, p.74) não parecem afetar Carmilla, que se mostra encolerizada apenas quando o andarilho repara em seus dentes: "tem um dente dos mais afiados... longo, fino, pontudo, como uma sovela, como uma agulha" (FANU, 2010, p.75).

Os dentes longos e pontiagudos como os de uma fera, que associam o vampiro à sucção do sangue e à animalidade, são mencionados pela primeira vez na prosa literária, em Carmilla, e tornam-se uma das características mais marcantes da imagem moderna do vampiro que se difundiu pela indústria cultural, mas a associação com a animalidade é tanto mais evidente na passagem em que Laura é atacada por um "gato monstruoso":

Mas, de súbito, vi um animal preto, cor de fuligem, semelhante a um gato monstruoso. Parecia ter cerca de $1,20 \mathrm{~m}$ ou $1,50 \mathrm{~m}$, pois era do tamanho do tapete que ficava diante da lareira; e andava de um lado para o outro, com o nervosismo ágil e sinistro de uma fera enjaulada. (...) Senti quando ela pulou, suavemente, na minha cama. Os dois olhos grandes se aproximaram do meu rosto e, de repente, senti uma pontada ardida, como se duas grandes agulhas penetrassem, a dois ou quatro centímetros de distância uma da outra, fundo em meu peito. Acordei com um grito. $\mathrm{O}$ quarto estava iluminado pela vela que queimava a noite inteira, $e$ vi um vulto de mulher ao pé da cama, um pouco à direita. Ela usava um vestido escuro e largo, e tinha os cabelos soltos, cobrindo-Ihe os ombros. (...) Enquanto eu olhava, o vulto pareceu se deslocar, aproximando-se da porta; então, a porta se abriu, e a figura se foi.

Senti-me, então, aliviada e novamente capaz de respirar e de me mover. Meu primeiro 
pensamento foi que Carmilla decidira me pregar uma peça, e que eu havia esquecido de trancar a porta. Mas, correndo até lá, constatei que a porta estava trancada, como de hábito, do lado de dentro. Tive medo de abri-la - estava apavorada. (FANU, 2010, p.88-89)

Laura ainda não associa a figura do gato monstruoso a Carmilla (o que se evidenciará apenas ao final da narrativa), a qual, astutamente, relata a Laura ter tido o mesmo "pesadelo" ou "visita sombria" durante a noite. Depois deste episódio, Laura passa a sofrer de cansaço e prostração, tomada por uma melancolia "da qual eu não queria me livrar". Essa reação é acompanhada de uma crescente dedicação e adoração de Carmilla por Laura: "Quanto mais me falhavam as forças e mais deprimida eu ficava, com mais ardor ela me desejava" (FANU, 2010, p.93).

Laura torna-se visivelmente fraca e doente, e mantém na descrição de seus sintomas uma alternância entre o prazer e o horror: "Durante um tempo, esse enlevo apenas aumentou, até alcançar um determinado ponto; então, aos poucos, uma sensação medonha, cada vez mais intensa, misturou-se a tal prazer" (FANU, 2010, p.93). Durante o sono, tem sensações "vagas e estranhas": "se assemelhava ao calafrio prazeroso que sentimos quando, banhando-nos num rio, caminhamos contra a corrente"; ao mesmo tempo em que "sonhos intermináveis", dos quais não se lembra nitidamente, "causavam uma impressão terrível, e uma sensação de esgotamento físico, como seu eu tivesse sido exposta a situações de perigo" (FANU, 2010, p.94). Ainda assim, duvida estar sendo atacada pelo oupire, cujas vítimas ela ouvia dizer que faleciam em dias; e não desconfia de Carmilla, até que em sonho, ouve uma voz: 
"Tua mãe te adverte a tomares cuidado com o assassino", momento em que surge uma luz e revela-se a imagem de Carmilla, "de pé, ao lado da minha cama, com sua camisola branca, coberta do queixo aos pés por uma imensa mancha de sangue" (FANU, 2010, p.95).

Ainda assim, Laura não associa esta cena à sucção de seu próprio sangue por Carmilla, mas pensa que isto seria um aviso de que a amiga estaria sendo assassinada. Sua identidade vampiresca só é suspeitada pela narradora quando esta ouve o relato do General Spieldorf, que recebera uma hóspede misteriosa e com os mesmos hábitos de Carmilla, e cuja filha, a qual apresentava os mesmos sintomas que Laura, falecera. O relato se dá nas ruínas do vilarejo de Karnstein, onde o general fora à procura do túmulo da Mircalla, a condessa vampira. Apenas ao final do livro a figura de Carmilla/ Mircalla é explicitamente descrita como vampira, abundantemente banhada em sangue:

A sepultura da condessa Mircalla foi aberta; o general e meu pai reconheceram, na face agora exposta, a bela e pérfida hóspede. Embora 150 anos houvessem se passado desde o funeral, a fisionomia se mostrava corada com o calor da vida. Os olhos estavam abertos; o caixão não exalava qualquer fedentina cadavérica. Os dois médicos, um ali presente, o outro representado pela pessoa do promotor público, atestaram fatos absolutamente fabulosos: uma tênue respiração e um breve batimento cardíaco. Os membros superiores e inferiores se mostravam flexíveis, a pele elástica, o caixão forrado de chumbo estava inundado de sangue, com uma profundidade de cerca de vinte centímetros, e naquele sangue o corpo flutuava. (FANU, 2010, p.140) 
Nota-se claramente, nos capítulos finais de Carmilla, a influência dos relatos presentes no Traités sur les revenants..., de Calmet, no que se refere às características da vampira em seu caixão e em sua execução, bem como na citação de autoridades e relatos oficiais/ jurídicos sobre o caso.

Além da ambiguidade entre a beleza/sedução e a figura monstruosa, temos também em Carmilla, assim como em La morte amoureuse, um sentimento amoroso pela vítima, e, neste ponto, é possível supor, a partir da menção de Laura ao fato de as vítimas dos vampiros morrerem em dias, que Carmilla estaria retardando sua morte, bebendo seu sangue aos poucos para evitá-la, como ocorre com Clarimunda em relação a Romualdo. Entretanto, em Carmilla, a relação entre o amor e a morte é explícita: em vários momentos da narrativa, ela declara a Laura, em palavras que a narradora diz não compreender, a perspectiva de que Laura se tornaria uma vampira, e de uma união entre elas na morte:

No êxtase da minha tremenda humilhação, vivo no calor da tua vida, e tu hás de morrer... morrer languidamente... na minha. Não consigo evitá-lo; assim como me aproximo de ti, vais te aproximar de terceiros, e tomarás consciência do êxtase dessa crueldade, que contudo não deixa de ser amor (...).

Mas, morrer como amantes... morrer juntas, para poder viver juntas. Meninas são lagartas enquanto vivem neste mundo, mas se transformam em borboletas quando chega o verão; no entanto, nesse ínterim, há vermes e larvas, você entende?

Com um olhar tímido e estranho, apressou-se em esconder o rosto no meu pescoço, entre os meus cabelos, suspirando sofregamente, quase 
soluçando, e apertando a minha mão com suas mãos trêmulas.

Sua face macia brilhava ao lado da minha.

- Querida, querida - ela murmurou. - Vivo em ti; e morrerás por mim; amo-te demais. (FANU, 2010, p.67; 77; 82, respectivamente - G6++rifos da autora)

Se em Carmilla, assim como em A morta amorosa, as protagonistas vampiras oscilam entre a beleza e a animalidade, e estabelecem relações amorosas com suas vítimas, algo diverso ocorre com Drácula, protagonista do romance homônimo de Bram Stoker. Assim como Lord Ruthven e Carmilla, ele possui origem nobre e hábitos aristocráticos. A influência da novela de Fanu é evidente no romance de Stoker, cujo cenário inicial é também o leste europeu, mais precisamente a Transilvânia, "umas das regiões mais selvagens e menos conhecidas da Europa" (STOKER, 2015, p.28). Para lá dirige-se Jonathan Harker, um jovem advogado de uma firma imobiliária, para negociar com o Conde Drácula a aquisição de propriedades em Londres. Aos poucos, Jonathan não apenas descobre-se prisioneiro do conde em seu isolado castelo, mas também a identidade demoníaca de seu anfitrião, registrando em seu diário as descrições de Drácula e os fatos insólitos e terríveis que presencia.

Enquanto Jonathan luta para fugir do castelo de Drácula e, depois, recupera-se em um hospital, este dirige-se a Londres, cidade em que faz de sua primeira vítima a jovem Lucy, pupila da srta. Mina Murray, a qual, por sua vez, era noiva de Jonathan e, posteriormente, será também atacada pelo vampiro. Depois da morte de Lucy e 
da leitura do diário de Jonathan, Mina escreve ao famoso Dr. Van Helsing, antigo professor do Dr. Seward - médico e amigo de Lucy e de seu noivo, Arthur, e de Quincey, um jovem americano também apaixonado por esta e que se junta a eles na caçada e extermínio de Drácula. O romance é composto pela alternância dos diários de tais personagens, e esta polifonia narrativa é uma das grandes novidades de Stoker em relação às narrativas vampirescas precedentes. Entretanto, como o foco deste texto é demonstrar a ambiguidade da personagem vampiresca entre o cadavérico/monstruoso e o belo/humanizado já no século XIX, deixemos a síntese do enredo e a questão da polifonia narrativa para analisarmos as descrições de Drácula, das três vampiras que quase atacam Jonathan e de Lucy.

Já no primeiro encontro com Drácula, Jonathan se revela confuso com os hábitos corteses do conde, os quais parecem destoar de sua aparência cadavérica e animalesca: Drácula é descrito como um homem "alto e velho, inteiramente barbeado com exceção de um longo bigode branco e trajando preto das cabeças aos pés"; ele o convida para entrar em seu castelo "com um gesto cordial" e "em inglês perfeito", mas avança "impulsivamente" sobre seu hóspede, assim que este cruza a porta, agarrando sua mão "com uma força que me fez retrair, efeito que não foi atenuado pelo fato de que sua pele era fria como gelo, parecendo mais a de um homem morto" (STOKER, 2015, p.45). O conde gentilmente carrega suas malas e oferece-lhe uma boa ceia; porém, embora Jonathan afirme que "as boas vindas corteses do conde pareceram dissipar todas as minhas dúvidas e receios", não deixa de observar sua "fisionomia bastante marcada":

A boca, pelo que pude ver sob o bigode grosso, era rígida e parecia até cruel, com dentes particularmente 
pontiagudos e brancos. Estes se ressaltavam por sobre os lábios, cujo notável rubor demonstrava uma impressionante vitalidade para um homem naquela idade. De resto, as orelhas eram pálidas e extremamente pontudas no alto. O queixo era largo e forte, e as maçãs firmes, embora magras. O efeito geral era de uma extraordinária palidez.

Até ali, só havia reparado no dorso das mãos dele quando postadas sobre os joelhos e à luz do fogo, e me pareceram bastante brancas e magras. Mas vendo-as agora de perto, não pude evitar notar que eram mãos bastante ásperas, largas, de dedos curtos e gordos. Estranhamente, havia pelos no centro da palma. As unhas eram compridas, finas e cortadas em pontas afiadas. Quando o conde inclinou para mim e suas mãos me tocaram, não pude evitar um calafrio. Talvez porque seu hálito era fétido, mas uma terrível sensação de náusea se apoderou de mim, que, por mais que me esforçasse, não consegui disfarçar. O conde, evidentemente, reparando nisso, recuou. E, com uma espécie de sorriso taciturno, que exibiu mais do que até então seus dentes protuberantes, sentou-se novamente de seu lado da lareira. (STOKER, 2015, p.47)

A descrição do primeiro encontro com Drácula, bem como das características físicas do personagem, sugere sua condição de animalidade e explicita a reação de repugnância de Jonathan a elas, o que difere significativamente da descrição do primeiro encontro de Clarimunda e Carmilla com suas amadas vítimas, e da aparência inicial destas vampiras, na qual predomina a descrição da beleza, da sensualidade e da atração exercida sobre Romualdo e Laura, respectivamente.

Ao longo do romance, os aspectos animalescos, repugnantes e monstruosos de Drácula ficarão cada vez mais explícitos. Entretanto, 
há uma diferença de caracterização entre este vampiro e as vampiras retratadas no romance, que são representadas pelo aspecto da beleza ou da sedução. As primeiras vampiras que aparecem na narrativa são as "três jovens damas" que abordam Jonathan quando este, desrespeitando as ordens do conde de se manter apenas em uma ala do castelo, adormece em uma sala que, outrora, deveria ter sido recinto para repouso ou recreação femininas:

As três tinham dentes brancos brilhantes que reluziram feito pérolas contra o rubi de seus lábios voluptuosos. Havia neles algo que me inquietava, um certo desejo e ao mesmo tempo um certo medo mortal. Senti no coração o impulso cruel e ardente que me beijassem com aqueles lábios rubros. (...)

Fiquei deitado, calado, espreitando, numa agonia de deliciosa ansiedade. A loira veio e se inclinou sobre mim até que senti o movimento de sua respiração. Em certo sentido, era um hálito doce feito mel, e produzia o mesmo tilintar de nervos de sua voz, mas com um amargor subjacente à doçura, um amargor agressivo como o que se sente no cheiro de sangue.

(...) A moça ajoelhou-se e inclinou-se sobre mim, simplesmente entregue ao próprio prazer maligno. Havia uma voluptuosidade deliberada que era ao mesmo tempo excitante e repulsiva, e, quando arqueou o pescoço, chegou de fato a lamber os lábios feito um bicho, até que pude ver à luz da lua a umidade cintilante de sua boca escarlate e da língua vermelha deslizando sobre os dentes pontiagudos. A jovem baixou cada vez mais a cabeça, à medida que descia os lábios por minha boca e ao longo de meu queixo, e parecia prestes a fechá-los em minha garganta. (...) Concentrei-me no toque macio e trêmulo dos lábios na pele hipersensível e 
nas pontas duras de dois dentes pontiagudos, que apenas me tocaram e se detiveram. Fechei os olhos num êxtase langoroso e aguardei, com o coração acelerado. (STOKER, 2015, p.71)

A descrição contém o erotismo já presente em Carmilla, apresentando as sensações de Jonathan com a mesma ambiguidade entre repulsa e desejo presente na novela de Fanu, porém, com predominância do segundo, na descrição do contato físico com a vampira. Embora ela não seja descrita propriamente como bela, mas "como um bicho", ela é atraente, tem lábios rubros e voluptuosos, e, ao contrário do conde, seu hálito é doce, e seu toque é macio (enquanto o de Drácula gera calafrios). Mas, em relação à beleza, é Lucy quem contraria a imagem do monstro, ao ser vista por Dr. Seward em seu caixão, meses depois de sua morte:

Lá estava Lucy, aparentemente como a havíamos visto na noite anterior ao enterro. Estava, se isso é possível, ainda mais radiantemente bela do que nunca, e mal pude acreditar que estivesse mesmo morta. Os lábios estavam vermelhos, não, mais rubros do que antes, e, nas faces, um delicado rubor. (STOKER, 2015, p.257)

Porém, posteriormente, Lucy também é apresentada como um monstro, quando chega a seu mausoléu com uma das suas vítimas. Mas, flagrada por Arthur, Seward e Van Helsing, tenta seduzir o ex-noivo:

A doçura havia se convertido em crueldade adamantina, impiedosa, e a pureza, em voluptuosa promiscuidade. (...) Com a luz concentrada sobre o rosto de Lucy, pudemos ver que os lábios estavam vermelhos de sangue fresco e que o fio escorrendo pelo queixo manchara a pureza da mortalha branca. 
(...) Ao nos fitar, seus olhos reluziram com um brilho profano, e o rosto se enfeitou com um sorriso voluptuoso. Oh, meu Deus, como estremeci ao presenciar aquilo! Com um movimento descuidado, cruel feito um demônio, ela jogou no chão a criança que até então trazia agarrada com força ao peito, rosnando feito um cão diante de um osso. (...) 0 sangue-frio deste gesto fez Arthur gemer também. Quando Lucy avançou na direção dele com os braços abertos e um sorriso lascivo, ele recuou e cobriu o rosto com as mãos. Mas ela continuou se aproximando dele e, cheia de langor e volúpia, o chamou (...).(STOKER, p.269-270)

Havia algo de diabolicamente meigo naquele tom de voz, algo que lembrava o tilintar do vidro e que ressoou em nossos cérebros mesmo que as palavras tenham sido dirigidas a outro homem. Quanto a Arthur, parecia em transe e, tirando as mãos do rosto, abriu os braços. (STOKER, p.269-270)

Novamente, na descrição de Lucy, a imagem da vampira é associada à sedução, embora não se poupem detalhes também na descrição de sua crueldade. Porém, essa ambiguidade não se constata na figura de Drácula, o protagonista, que nunca é descrito como belo ou atraente. Ele domina Lucy e Mina, faz com que entrem em transe e alimenta-se do sangue delas, mas em nenhuma parte do romance, nos diários destas personagens, encontram-se em seus relatos sensações voluptuosas associadas ao conde. Ao contrário, a sensação de contato físico com ele é descrita como apavorante e repulsiva:

Ao lado da cama, como que saído de dentro da neblina, ou melhor, como se a neblina tivesse se condensado em sua figura, pois sumira inteiramente, havia um homem alto, magro e todo de preto. 
Reconheci-o imediatamente pelas descrições. (...) Por um momento, meu coração parou de bater, eu teria gritado se não estivesse paralisada. Nesse meio tempo, ele falou, num sussurro agudo e cortante, apontando para Jonathan:

"Silêncio! Se der um pio, esmago os miolos dele na sua frente". Fiquei apavorada e perplexa demais para fazer ou dizer qualquer coisa. Com um sorriso de escárnio, ele me segurou firme pelo ombro com uma das mãos e despiu meu pescoço com a outra, dizendo: "Primeiro, um pouco de refresco em recompensa por meu esforço. Melhor ficar quieta. Não é a primeira nem a segunda vez que suas veias aplacam minha sede!" Eu estava aturdida e, estranhamente, não quis impedi-lo. Suponho que seja parte da maldição horrível que recai sobre a vítima quando ele a toca. $E$, oh, meu Deus, meu Deus, tenha piedade de mim! Ele pôs os lábios fétidos em meu pescoço. (...)

Senti minha força se esvaindo, como se fosse desmaiar. Não sei dizer por quanto tempo essa coisa horrível durou, mas me pareceu uma eternidade até que ele retirasse sua boca asquerosa, impura e insolente de meu pescoço. Vi que estava pingando de sangue fresco. (STOKER, 2015, p.357-358)

Nesta cena, em que Mina relata a Van Helsing o ataque de Drácula, chama a atenção a postura ameaçadora do conde. Ao contrário de persuadir pela sedução, ele ameaça matar Jonathan, e domina a vontade de Mina para que ela se submeta a ele, deixando-o sugar seu sangue. Nenhum cuidado ou remorso é demonstrado neste ato, motivado apenas pelo "aplacar a sede" - Drácula serve-se do sangue de Mina como o de qualquer outro ser humano, não demonstrando nenhum afeto pela vítima. Ao 
contrário das bocas voluptuosas das vampiras, a expressão "lábios fétidos" e os adjetivos "asquerosa, impura e insolente" explicitam a repulsa causada ao contato físico do vampiro.

Depois de ter sido atacada por Drácula, Mina sente-se impura, afirmando que não poderia mais tocar nem beijar Jonathan (STOKER, 2015, p.354). Mina não se transforma em uma vampira porque, antes que ela morresse, Drácula é morto, depois de perseguido de Londres até seu castelo na Transilvânia. Mas ela faz Van Helsing prometer-lhe que, se necessário, ele a mataria e queimaria seu corpo, libertando sua alma do destino terrível de ser tornar um ser asqueroso e demoníaco. A reação de Mina difere significativamente das reações de Romualdo e Laura - aquele sente saudades de Clarimunda, sua grande paixão; esta se sente apenas aliviada por ter sobrevivido ao perigo por qual passou, mas não declara se sentir impura ao descobrir que travou relações tão íntimas com uma vampira. Nenhum dos dois expressa qualquer temor de tornaremse também vampiros depois de suas mortes.

\section{CONSIDERAÇÕES FINAIS}

Chegamos ao fim deste percurso de leituras de narrativas vampirescas, no qual explicito as variações da imagem do vampiro ao longo do tempo e de diversas obras, com o intuito de analisar como algumas caracterizações deste personagem em obras contemporâneas se formaram ao longo dos séculos XVIII e XIX.

A princípio, parecia-me que a narrativa vampiresca literária ia se distanciando da imagem do vampiro dos relatos míticos, de forma que, a partir do século XIX, teríamos um vampiro limpo, integrado socialmente, associado à sedução. Mas uma leitura atenta das obras 
descritas neste trabalho revelou-me de fato uma alternância de imagens, por vezes, sutilmente, dentro de uma mesma obra: a do vampiro monstruoso (cadavérico, repugnante, fétido, animalesco, obcecado por sangue), que causa medo e terror nas vítimas; e a do vampiro humanizado, aristocrático ou pertencente a uma classe econômica dominante (fisicamente atraente, sedutor, persuasivo), que não apenas conquista suas vítimas para sugar-lhes o sangue, mas estabelece relacionamentos com e apresenta sentimentos por elas.

Portanto, não há como estabelecer uma distinção entre estas duas imagens tomando por critério a cronologia das obras, pensando-se que as mais antigas se aproximariam mais do vampiro mítico monstruoso, enquanto, nas mais recentes, prevaleceria a imagem do vampiro literário humanizado - hipótese que se desfez na comparação entre A morta amorosa, de Gautier, Carmilla, de Fanu, e Drácula, de Stoker. Conforme explicitado ao longo deste artigo, na primeira, de 1836, a personagem vampira é quase sempre bela, sedutora e amorosa; na segunda, de 1874, apenas ao final se tem a figura de Carmilla como um monstro, mas ao longo da narrativa, ela também é uma jovem nobre e atraente; e no terceiro, que está no limiar do século XX (1897), Lucy e outras vampiras são atraentes e sedutoras, enquanto Drácula é um vampiro que se aproxima muito da imagem animalesca e monstruosa, no máximo, configurando-se como misterioso, mas nunca sedutor.

A análise destas obras e a constatação da ambiguidade entre os aspectos monstruosos e humanos na personagem vampiresca nos leva a constatar, enfim, que a representação do vampiro belo, atraente, e que sente culpa ou pesar por se alimentar do sangue de vítimas, por quem eventualmente se apaixona, não é tão inovadora 
quanto parece e bem anterior às narrativas de Meyer, ou mesmo às de Anne Rice. Clarimunda e Carmilla são as ancestrais oitocentistas de Louis, Edward e outros vampiros belos e apaixonados de narrativas contemporâneas.

\section{REFERÊNCIAS}

BAUDELAIRE, Charles (1857). Les fleurs du mal. Paris: Poulet-Malassis et De Broise Libreurs-Éditeurs. Bibliotèque Nacionale de France. In https://gallica.bnf. fr/ark:/12148/bpt6k1057740n/f9.item Acesso em 15.Fev.2019.

CALMET, Augustin (1751). Traités sur les apparitions des esprits, et surles vampires, ou les revenans de Hongrie, de Moravie, \& c. Nouvelle édition revûe, corrigeé \& augmentée par l'Auter. Tome II. Paris: Chez Débure l'aîné. Fonte: Bibliotèque Nacionale de France. In http://gallica.bnf.fr/ark:/12148/bpt6k68180w/f2.image Acesso em 15.Fev.2019.

CLARK, Lynn Schofield (2005). "Touched by a vampire named Angel", In: From Angels to Aliens: Teenagers, the Media and the Supernatural. New York: Oxford University Press, p.46-73.

COSTA, Bruno (Org.) (2010). Contos clássicos de vampiro. São Paulo: Hedra.

FANU, Sheridan Le (2010). Carmilla - A vampira de Karnstein. São Paulo: Hedra. FERRAZ, Salma; MARTINS, Leonor (2017). "Vampiros: o mito é o nada que é tudo e de todos". In: FERRAZ, Salma; LOYOLLA, Dirlenvalder; MARTINS, Patrícia Leonor; CANÊDO, Cátia (Orgs.). Sobre o vampirismo de Drácula a Crepúsculo: a saga do vampiro na cultura ocidental. São Paulo: Todas as Musas. p.9-30.

FREUD, Sigmund (2012). Totem e tabu. Algumas concordâncias entre a vida psíquica dos homens primitivos e a dos neuróticos. São Paulo: Penguin \& Companhia das Letras.

KOHN, Max (2012). "O vampiro, um não morto ainda vivo". Revista Ágora, Rio de Janeiro. XV(2), jul/dez, 301-309.

KOKKOLA, Lydia (2011). "Virtuous vampires and Voluptous Vamps: Romance Conventions Reconsidered in Stephenie Meyer's 'Twilight' Series". Children's Literature in Education, jun, 42, 165-179, In https://link.springer.com/ article/10.1007/s10583-010-9125-9 Acesso em 20.Jun.2019. 
LECOUTEUX, Claude (2005). História dos vampiros: autópsia de um mito. São Paulo: Editora UNESP.

MEYER, Stephenie (2008). Twilight. London: Atom. (2009). New Moon. London: Atom.

ROAS, David (2012). "Mutaciones pós-modernas: del vampiro depredador a la naturalización del monstruo" Revista Letras \& Letras. Uberlândia-MG, 28(2), jul./dez.

(2014) "El monstruo pós-moderno y los limites de lo fantástico", In: GARCIA, Flávio; BATALHA, Maria Cristina; MICHELLI, Regina (Orgs.). (Re)Visões do Fantástico: do centro às margens, caminhos cruzados. Rio de Janeiro: Dialogarts Publicações.

STOKER, Bram (2015). Drácula: edição comentada. Rio de Janeiro: Zahar.

ULIANO, Cristiane Gonçalves. "O vampiro do século XXI: a recriação do mito", In: FERRAZ, Salma; LOYOLLA, Dirlenvalder; MARTINS, Patrícia Leonor; CANÊDO, Cátia (Orgs.). Sobre o vampirismo de Drácula a Crepúsculo: a saga do vampiro na cultura ocidental. São Paulo: Todas as Musas. p.185- 200. 


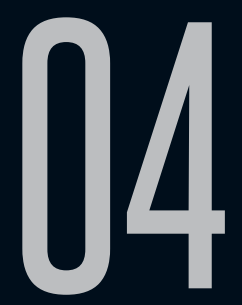

\section{JACQUES CHESSEX: O ESCRITOR-VAMPIRO DE ROPRAZ}

Ana Amelia Gonçalves da Costa (UERJ)

Recebido em 15 mar 2019. Ana Amélia Gonçalves da Costa é Doutora em Literatura Aprovado em 22 mai 2019.

Comparada (UERJ) e bolsista do programa Pós-Doutorado Nota Dez, da FAPERJ. Especializada em Língua e Cultura Francesas pela Universidade de Lausanne, faz pesquisa sobre a Literatura Suiça de Língua Francesa, com foco na obra do escritor helvético Jacques Chessex. Formada em Filosofia, participa do projeto de extensão universitária Órgana, do IFCS/UFRJ, de línguas instrumentais para a Filosofia, como docente de Francês. Link Lattes: http:// lattes.cnpq.br/4737061470720275

Resumo: Em Le vampire de Ropraz (2007), livro do escritor suíço de língua francesa Jacques Chessex (1934-2009), a condição da falência da memória enquanto lugar da expiação histórica é construída através da imortalidade do vampiro, que expressa, por outro lado, uma crise perene do fazer literário, crise essa que deve ser compreendida no sentido positivo de renovação. Para seguir esse caminho é preciso pensar o pós-modernismo, em consonância com a canadense Linda Hutcheon, como um movimento que questiona sistemas centralizados, hierarquizados e fechados, sem, no entanto, destruí-los. O questionamento, em Jacques Chessex, é sinônimo de ironia, traço marcante em muitos de seus escritos. No caso de Le vampire de Ropraz é parodiando o estilo romântico que Jacques Chessex tece sua crítica à hipocrisia e ao não-dito, revelando 
a ambiguidade de uma época que une degradação e progresso, conforme define Milan Kundera em seu $A$ arte do romance. $\mathrm{O}$ vampiro da obra chessexiana não tem $o$ arquétipo do personagem folclórico, distanciando o romance de uma obra de literatura fantástica. É a simbologia da exclusão, entretanto, que transfigura o protagonista no perfeito vampiro, no jogo simbólico de uma ambiguidade traduzida, pelo autor, em ruptura e transcendência identitárias.

Palavras-chave: Jacques Chessex; Literatura Suiça; Identidade autoral; Memória; Ironia.

Résumé: Dans Le vampire de Ropraz (2007), roman de l'écrivain suisse francophone Jacques Chessex (19342009), la condition de la faillite de la mémoire en tant que lieu d'expiation historique se construit à travers l'immortalité du vampire, qui exprime, en revanche, une crise perpétuelle de la production littéraire, prise dans son sens positif du renouveau. Pour suivre cette voie, il faut penser au postmodernisme avec la canadienne Linda Hutcheon, comme un mouvement qui questionne les systèmes centralisés, hiérarchisés et fermés, sans toutefois les détruire. La mise en question, chez Jacques Chessex, est synonyme d'ironie, caractéristique frappante dans plusieurs de ses écrits. En ce qui concerne Le vampire de Ropraz, à travers la parodie au style romantique Jacques Chessex élabore sa critique de l'hypocrisie et du non-dit, révélant l'ambiguïté d'une époque qui associe dégradation et progrès, selon la compréhension de Milan Kundera dans son œuvre L'Art du roman. Le vampire de l'œuvre chessexienne n'a pas l'archétype du personnage traditionnel, ce qui le distingue de la littérature fantastique. C'est cependant la symbologie de l'exclusion qui transfigure le protagoniste dans le vampire parfait, sous le jeu d'une ambiguïté symbolique traduite, par l'auteur, en rupture et transcendance identitaires.

Mots-clés: Jacques Chessex; Littérature suisse; Identité de l'auteur; Mémoire; Ironie. 
Jacques Chessex foi o único escritor suíço a receber o Prêmio Goncourt, em 1973, com o romance L'Ogre. Apesar disso, a obra do escritor suíço de língua francesa ainda é inédita no Brasil. Em vida, ele publicou mais de 30 livros de poesia; 40 romances, livros de contos e de crônicas; 10 obras reunindo ensaios e críticas literárias, e outras tantas, sozinho ou em coautoria, contendo críticas de arte. Entre seus romances, destaca-se Le Vampire de Ropraz, de 2007. ${ }^{1}$

A estrutura do romance, a exemplo de muitos outros do autor, é concisa, lancinante e vertiginosa. A narrativa factual de Le Vampire de Ropraz é fortemente ancorada no tempo e no espaço. A primeira frase do romance, reiterando o título, situa o leitor em Ropraz, cidade do Alto Jura, no cantão de Vaud. O livro começa com a morte da jovem Rosa Gilliéron, em 17 de fevereiro de 1903, e termina com o reconhecimento laboratorial do corpo de CharlesAugustin Favez, em 1920.

Seguindo sucessão cronológica, o túmulo de Rosa é violado em 21 de fevereiro. Um segundo episódio semelhante ocorre em 14 de abril, no vilarejo de Carrouge, a oito quilômetros de Ropraz. A exemplo de outras obras de Jacques Chessex, o horror não encontra limites estilísticos: um professor, vigiando a recreação de seus alunos, descobre que a "bola" do jogo de futebol é o crânio de Nadine Jordan. "Na hora seguinte, todo o horror do ritual fúnebre é descoberto. Túmulo aberto, caixão sem lacre, ali também, cadáver violado, manchas de esperma e de saliva ao redor do umbigo e nas $\operatorname{coxas}^{\prime 2}$ (CHESSEX, 2007, p.37-38). O túmulo da terceira vítima, 1 A tradução do romance "Le Vampire de Ropraz" é parte de meu projeto de pósdoutorado, contemplado com a bolsa Pós-Doutorado Nota Dez, da Faperj.

2 Todas as traduções do romance aqui citadas foram feitas por mim. 
Justine Beaupierre, é violado no mesmo mês de abril. O tipo físico das três jovens é o mesmo, fazendo supor que o necrófilo escolhe antecipadamente as suas vítimas.

O vilarejo de Ropraz é pintado como um local "de lobos e de abandono no começo do século XX" (CHESSEX, 2007, p.11). O campo lexical da descrição inclui os adjetivos "pendurado", "opacos", "desertos", "sombrios", "estreitos" e "baixas". Na zona rural, Ropraz é uma cidade marcada por altos índices de enforcamento dentro das fazendas: "As ideias não circulam, a tradição pesa, a higiene moderna é desconhecida. Avareza, crueldade, superstição, não estamos longe da fronteira de Friburgo, onde a bruxaria aflui" (2007, p.11). A lei é a do medo. Medo do sobrenatural, dos lobos e dos ursos. Por isso, as armas sempre estão carregadas, as armadilhas montadas. À noite, preces de conjuração ou de exorcismo enchem o ar, apesar do protestantismo reinante.

$\mathrm{Na}$ cidade agrícola e pobre, a ameaça vem de fora e o estrangeiro é o indiscreto e o ladrão. Sem uma vida digna desse nome, a população local acaba se assemelhando aos porcos, tamanha a convivência com os suínos. A miséria, entretanto, não se resume a questões econômicas, já que "a miséria sexual, como será designada mais tarde, se une à errância do medo e da imaginação do mal" (CHESSEX, 2007, p.13). A culpabilidade por esses exacerbados instintos sexuais vem, obviamente, dos "quatro séculos de calvinismo imposto". Paralelamente, o inverno, com sua melancolia, atiça os nervos. Assim, os rituais, as preces e as poções negras da descrição chessexiana sobrepujam e escondem qualquer possível rastro de beleza do lugar. Com essa ambientação macabra, o autor constrói um clima de chegada da ameaça, naquele que é o espaço de vitória da loucura e do medo. 
Estamos na metade do romance. Onze de maio de 1903. É nesse ponto que o autor nos apresenta Charles-Augustin Favez, de 21 anos, jovem que tem o costume de praticar sexo com os animais da fazenda: "E ele se diverte com nossos animais! Ele rondaria nos cemitérios? E se o culpado fosse Favez, Favez no túmulo de Rosa, ainda ele em Carrouge, ainda Favez em Ferlens! Claro que é Favez, o sádico. É Favez, o monstro. É ele, o vampiro de Ropraz" (CHESSEX, 2007, p.47).

Assim que entra em cena, o passado do jovem desajustado é revelado: nascido em um meio desfavorecido, em que predominam o incesto e o alcoolismo, aos três anos de idade Favez é retirado da família. Começa, então, uma sequência de abusos e explorações nas famílias em que é alocado. Por sua vez, o menino cresce com episódios de ausência e perda de memória, além de crises de cólera e tendência ao alcoolismo. É o bode expiatório perfeito para os crimes que precisam de um culpado, em uma sociedade que "precisa limpar o país do monstro que envenena a sua existência" (2007, p.69).

Encarcerado, Charles-Augustin Favez começa a receber a visita de uma misteriosa dama que se veste de branco. É nesse ponto que o autor inicia seu jogo de reversões que, analisado no decorrer do presente artigo, revela tanto a paródia ao estilo romântico operada pelo autor quanto a crítica à hipocrisia e ao não-dito, recorrentes na sociedade helvética lida por Jacques Chessex. Em sua cela, o denominado vampiro tem medo da mulher sem identidade que o assedia e tem medo na população vingativa que clama por sangue. O medo é tanto que ele tenta se matar. E nem isso ele consegue.

Apesar de algumas evidências contrárias, em 24 de dezembro de 1903, ironicamente data da véspera de Natal, Charles-Augustin 
Favez, o vampiro de Ropraz, é condenado à prisão perpétua. Após 12 anos aprisionado no hospital psiquiátrico de Cery, Favez consegue fugir e se alistar como voluntário no exército francês. Na Legião Estrangeira, seu comandante é Frédéric Saucer, "que escreveu alguns poemas sob o nome de Blaise Cendrars" (2007, p.85). A proximidade dos dois faz com que Cendrars arranque algumas confidências de seu comandado, que servirão de base para a futura escritura do livro que será intitulado Moravagine. De personagem-vampiro a personagem-inspiração, a saga de CharlesAugustin Favez não poderia ter fim com a sua morte. Não tem.

Morto no mesmo combate em que Blaise Cendrars tem o braço direito arrancado, o corpo do vampiro de Ropraz fica abandonado em campo de batalha e seu rastro se perde. Até o dia do sorteio do soldado desconhecido, em 21 de novembro de 1920. "É sobre os restos de um único herói anônimo que arderá a chama que jamais se apaga, sob o glorioso Arco do Triunfo" (2007, p.86). Pesquisas de DNA permitiram supor que os restos do soldado desconhecido pertenceriam ao cidadão vaudois Charles-Augustin Favez, alistado voluntariamente, em fevereiro de 1915, no exército francês em guerra. O soldado teria sido morto em frente à Fazenda Navarin no dia 28 de setembro do mesmo ano.

O soldado desconhecido, heroicamente honrado pelo Chefe de Estado, pelas badaladas aos mortos e pela saudação à Bandeira a cada 14 de julho, ninguém mais seria do que um louco e um criminoso reincidente de origem suíça, da mais terrível memória no alucinado repertório de relatos dos mortos-vivos. É óbvio que as autoridades em questão fizeram vista grossa sobre os resultados dessa análise e o escândalo foi abafado. Dessa forma, diz Chessez 
em seu romance, somos poucos a desconfiar: no glorioso Arco do Triunfo, sob a chama do soldado desconhecido, repousa Favez, o vampiro de Ropraz, que dorme com um olho só, enquanto espera uma nova noite para despertar.

Como veremos a seguir, toda a trama elaborada por Jacques Chessex se presta a leituras diversas, entre as quais a experiência do tempo circular na ficção, enquanto artifício da memória vista como recusa do esquecimento. Sob o manto da ironia, a memória desvelada pelo escritor faz emergir um tempo-verdade ambíguo e paradoxal, ancorado em um espaço que inclui tudo aquilo que não aparece. A paródia do estilo romântico se presta, assim, como opção literária para efetuar ficcionalmente uma reelaboração crítica do passado. Nos meandros desses jogos, nada mais oportuno do que transformar o imortal e sanguinário vampiro em personagem eternamente reverenciado, ironicamente aprisionado no túmulo do herói desconhecido.

\section{ETERNIDADE E CIRCULARIDADE}

O vampiro é, antes de tudo, a figura mítica da eternidade. Na obra de Chessex, a designação ocorre no capítulo IV. O vampiro de Ropraz, como a imprensa alcunhou o violador da tumba de Rosa, é o "bebedor de sangue". Muitos são os candidatos a "vampiro" e o medo está na ordem do dia. Em Le Vampire de Ropraz o rumor é o vento que espalha o ódio e a violência: "Inveja, ciúme mesquinho, acerto de contas ancestrais, pretendentes rejeitados por Rosa ou por seu austero pai, particulares lesados por decisões do juiz, politiqueiros focados em suas carreiras, solitários, tímidos, compulsivos apaixonados e obcecados pela pureza da bela 
jovem..." (CHESSEX, 2007, p.25). O medo é tanto que "[...] por todos os lados apareceram as imagens do Cristo guardadas do tempo do Catolicismo" (2007, p.26).

É preciso assinalar, para compreender a força da alcunha, que Ropraz fica a menos de 50 quilômetros de Friburgo, onde, até a metade do século XVIII, a Justiça condenava cidadãos acusados de praticar bruxaria. Friburgo detém o nefasto recorde de ser o cantão suíço que mais queimou "bruxos" entre os séculos XV e XVIII. ${ }^{3}$

Paralelamente, a relação do vampirismo com o movimento romântico é tão histórica quanto metafórica. Visando revolucionar uma arte subsumida ao reino do classicismo e da razão, os românticos das letras francesas sofrem com a expressão de suas finitudes, tédio e melancolia. O século em questão é o XIX, que em sua linhagem romanesca testemunha o entusiasmo pelo romance noir, fantástico e irracional. La Peau de chagrin, de Balzac, foi publicado em 1831; "La Morte amoureuse", de Gautier, é um conto de 1836. Entre 1856 e 1875, Paul Féval publica Les Drames de la mort, Le Chevalier Ténèbre e La Villa-vampire, romances que têm por tema o vampiro.

Em um artigo intitulado "Le vampirisme, de la légende à la métaphore ${ }^{\prime \prime}$, Jean Marigny, professor da Universidade Stendhal, em Grenoble, e especialista do mito do vampiro, afirma que a palavra vampiro aparece na língua francesa no início do século XVIII, tendo

3 In http://www.rts.ch/video/info/couleurs-locales/5748655-fribourg-est-I-un-descantons-romands-a-avoir-le-plus-brule-de-sorciers-entre-le-15e-et-le-18e-siecle.html Acesso em 22.Jan.2019.

4 Artigo apresentado no colóquio sobre o vampirismo na literatura e nas artes, ocorrido em Cerisy-la-Salle, em agosto de 1992. Publicado na obra: FAIVRE, Antoine (1993) (org.). Les Vampires - Colloque de Cerisy. Cahiers de l'Hermétisme. Paris: Éditions Albin Michel. 
o conceito de vampirismo evoluído na literatura, no cinema e nas artes gráficas a partir do século XIX. Ao abordar o alargamento do campo semântico da palavra "vampiro", Jean Marigny enfatiza os desvios de sentido em que o sangue passa a ter valor simbólico:

Victor Hugo utilizou o termo "vampiros" para designar os tiranos de toda espécie e, no século $X X$, os bolcheviques, avatares de "o homem com a faca entre os dentes", depois os nazistas e os stalinistas que reinaram pelo terror, sem esquecer os capitalistas sedentos de riquezas, foram constantemente comparados a vampiros. Seja qual for a cor política à qual pertençamos, somos naturalmente tentados a considerar os representantes de campos opostos como vampiros. (1993, p.18 - tradução minha)

Ao completar sua análise, Jean Marigny cita a aparição metafórica do termo no meio médico, quando o termo vampiro foi aplicado a certos tipos de doentes mentais, mencionando casos de necrofilia, violência e sadismo. E conclui:

Esse tipo de desvio semântico nos conduz a léguas de distância dos vampiros tradicionais dos Cárpatos, mas nos mostra, evidentemente, que, há mais de dois séculos, o vampirismo, que era apenas o produto de superstições de outra era, foi revestido de valores metafóricos que refletem preocupações do mundo moderno. Essa evolução é particularmente sensível na literatura e nas artes. (1993, p.21 - tradução minha)

O jovem alcoólatra e desajustado Charles-Augustin Favez tem o perfil perfeito para dar corpo ao vampiro de Ropraz, agravado pelo fato de ter sido colega de turma da vítima Rosa Gilliéron. Assim, Favez faz parte da memória de Rosa. Ao amarrar os fios das memórias de 
seus personagens, Jacques Chessex constrói uma experiência do tempo que substitui a noção de eternidade por aquela, ricoeuriana, de circularidade. Esse caráter circular da proposição ricoeuriana repousa na assertiva de que "o que se narra é o tempo, a ação que se desenvolve no tempo e que é refigurada pela narração", conforme resume Constança Marcondes Cesar no artigo "Temporalidade e literatura". ${ }^{5}$ Ela completa: "Condensando o tempo, a narração apresenta a vida como uma totalidade, fazendo aparecer sua relação com a experiência vivida do leitor e pondo em relevo a relação entre o quantitativo e o qualitativo do tempo" (2011, p.170).

No artigo supracitado, Constança Marcondes Cesar compreende, a partir da obra em três volumes Tempo e narrativa, de Paul Ricoeur, que:

O homem não apenas está no tempo, na sucessão cronológica dos dias e das horas, mas é tempo, isto é, existe num horizonte que, pela memória, abarca o passado e, pela prospecção, pelo projeto, indaga e delineia o futuro. Desdobrando-se em passado, presente e futuro, tornando o passado presente a si pela memória, e o futuro também presente pela antecipação e projeto do agir e do ser, o homem presente a si, consciente de si, se expressa no tempo e como tempo. Assim, a consciência é, para o homem, consciência de si, desvendada ao longo da vida, no tempo. (2011, p.165)

Esse tempo em cujo horizonte reside a memória, passado no presente, é aquele que, na interpretação de Paul Ricoeur, é re(a) presentado pela ficção. Se a memória é a reunião de dois tempos,

5 Artigo pulicado em: PAULA, Adna Candido de (2011); SPERBER, Suzi Frankl (Org.). Teoria literária e hermenêutica ricoeuriana - Um diálogo possível. Dourados, MS: UFGD, p.165-175. 
a noção vampiresca de eternidade pode ser interpretada como circularidade e permanência, posicionando o romance de Jacques Chessex no presente espaciotemporal, substantivo e verbo, de um homem que se expressa no tempo e como tempo. Esse tempo é também aquele metaliterariamente indicado na paródia que, em suas duas vozes, trabalha com a presença (gênero pós-moderno, parodístico) e com a ausência (texto romântico, parodiado).

O tempo (circular) da narrativa chessexiana é aquele da recusa do esquecimento. Só assim, atualizando a memória abraçada ao esquecimento, é que o narrador Jacques Chessex dialoga com seu leitor. A experiência compartilhada por Chessex é a (sua) experiência individual, que, ao ocupar o lugar da experiência coletiva relacionada à tradição oral, é aquela proporcionada pelo romance, conforme teoriza Walter Benjamin, especialmente em seu "O narrador".

Paralelamente, o vampiro de Ropraz enterrará suas memórias em um túmulo eterno. Para que o horror da guerra jamais seja esquecido, é erigido o túmulo do herói desconhecido. Em uma circularidade temporal exemplar, nada mais irônico do que a qualificação de vampiro para esse herói de guerra anônimo. Assim, a memória eterna não terá como oponente o esquecimento, e sim, o anonimato. Esquecer não é o mesmo que desconhecer, parece nos revelar Chessex. O vampiro de Ropraz não poderá ser relegado ao esquecimento porque, anônimo, tornou-se eterno.

É também assim, no anonimato que gera a eternidade, que a crítica de Jacques Chessex se expande ao tempo cristão da unicidade e da proximidade do fim. A humanidade está condenada ao recomeço em fluxo ininterrupto, parece nos dizer Chessex, e precisa aprender a conviver como essa tortura. O mito do vampiro, conforme nos indica 
Claude Lecouteux no livro História dos vampiros: autópsia de um mito (2005), é construído no terreno da incerteza:

Mas o que nos diz o mito? Se nos ativermos à definição etimológica do termo, trata-se de uma linguagem, portanto o vetor de uma mensagem de valor universal, resultado de uma visão do mundo, explicação de questionamentos suscitados pela experiência. Diz-nos que aquilo que o cristianismo, religião dominante, afirma sobre a vida e a morte é inexato, que não há fronteira nitidamente perceptivel entre estas, que o morto possui também uma existência, que ele pode falar e agir, desde que the forneçam um motivo. (2005, p.176)

A essa definição do significado mítico do vampiro, ser configurado no limiar entre os tempos da vida e da morte, podemos unir a concepção cristã de finitude. A alma imortal cristã alcança a sabedoria e, portanto, não pode ser aquela sujeita ao eterno retorno. O tempo cristão é finito e irreversível. Na ficção, entretanto, conforme nos ensina Paul Ricoeur, o tempo tornase tempo humano na medida em que está articulado de modo narrativo e a ação temporal é refigurada pela narração. Dessa forma, as fronteiras entre o tempo real e o tempo narrado são rompidas, para que emerja uma nova experiência temporal. A recusa ao esquecimento é, assim, metáfora do tempo que ainda virá, que sempre virá, carregando em seu manto os rastros daquilo que foi e, presentâneo, os rastros daquilo que é.

\section{A MEMÓRIA DO TEMPO E O TEMPO DA MEMÓRIA}

Analisada pelo prisma de desvelamento da memória, que caracteriza a obra do autor, a questão do tempo em Jacques Chessex 
parece coincidir com a visão aludida por Milan Kundera no início de seu $A$ arte do romance. Na obra teórica A arte do romance (2009), publicada em 1986, o escritor tcheco Milan Kundera considera que o romance "sonda o tempo", de forma que "o caminho do romance se esboça como uma história paralela dos tempos modernos" (2009, p.16). Entre os denominados paradoxos terminais dos tempos modernos, relacionados por Kundera à evolução do gênero romanesco, está aquele que parece nortear as obras tardias de Jacques Chessex:

Por exemplo: os tempos modernos cultivavam o sonho de uma humanidade que, dividida em diferentes civilizações separadas, encontraria um dia a unidade e, com ela, a paz eterna. Hoje, a história do planeta forma, enfim, um todo indivisível, mas a guerra, ambulante e perpétua, é que realiza e assegura essa unidade da humanidade há muito tempo sonhada. A unidade da humanidade significa: ninguém pode escapar em nenhum lugar. (2009, p.18)

Ninguém pode escapar em nenhum lugar. Entre os quatro apelos do romance (apelo da diversão, apelo do sonho, apelo do pensamento e apelo do tempo), Milan Kundera define o apelo do tempo como:

O período dos paradoxos terminais incita o romancista a não limitar mais a questão do tempo ao problema proustiano da memória pessoal, mas estendê-la ao enigma do tempo coletivo, do tempo da Europa, a Europa que se volta para olhar seu passado, para fazer seu balanço, para apreender sua história, como um velho que apreende com um único olhar sua própria vida escoada. $(2009$, p.20) 
A expressão "paradoxos terminais da modernidade" é utilizada por Kundera para designar a ambiguidade de uma época que é "ao mesmo tempo, degradação e progresso" (2009, p.12). Ou seja, é uma expressão que anuncia a estética romanesca de um tempo histórico assolado por duas guerras mundiais e que, concomitantemente, ergue-se sobre um período estreitado entre os modos de pensar moderno e pós-moderno. Nesse momento de reconfiguração do pensar, dois pontos que unem o moderno e o pós-moderno nos interessam particularmente: as novas formas de lidar com o tempo e com o passado, e as relações entre ficção e realidade.

Defendendo que "o romance acompanha o homem constante e fielmente desde o princípio dos tempos modernos" (2009, p.13), Milan Kundera usa a imagem do Dom Quixote que saiu de casa "e não teve mais condições de reconhecer o mundo" (2009, p.1314) para espelhar uma era, a moderna, em que vigora a sabedoria da incerteza, ou seja, "ao invés de uma só verdade absoluta, muitas verdades relativas [que] se contradizem" (2009, p.14). É nessa sabedoria da incerteza - a relatividade essencial das coisas humanas - que Jacques Chessex edifica sua obra tardia e constrói personagens como Charles-Augustin Favez, de Le Vampire de Ropraz. A sabedoria da incerteza reveste a dupla função de iluminar novos modos de pensar complementares, que situam a pós-modernidade como um processo mais reflexivo do que recusador, ao mesmo tempo em que posiciona Jacques Chessex no lugar concedido ao intelectual por Umberto Eco, como aquele que incomoda, por ser a consciência crítica do grupo. ${ }^{6}$

6 ECO, Umberto (2003). "A função dos intelectuais". Revista Época, fev.03. Inhttp:// revistaepoca.globo.com/Revista/Epoca/0,,EDR55351-6075,00.html. Acesso em 29Jan.2019. 
Jacques Chessex, em seu fazer literário, posiciona-se, assim como Milan Kundera, como agente desafiador de tudo o que parece culturalmente óbvio e iluminado. Especialmente na forma de lidar com o tempo, fator que, na escritura de Chessex, é conjugado ao espaço. O tempo-verdade ambíguo e paradoxal, iniciado na modernidade e estendido ao pós-moderno, é revelado, na obra de Jacques Chessex, através da ironia. É nesse espaço paradoxal, portanto, que o autor propõe um diálogo entre passado e presente, em que a relação temporal é crítica e não, nostálgica.

Tal postura crítico-dialogal é por si só pós-moderna, se considerarmos com Linda Hutcheon, em Poética do pósmodernismo: história, teoria, ficção (1991), que a "poética"7 do pósmodernismo é válida enquanto "estrutura conceitual flexível que possa, ao mesmo tempo, construir e conter a cultura pós-moderna e nossos discursos tanto a seu respeito como adjacentes a ela" (1991, p.11). A teórica canadense - para quem "o pós-moderno é um fenômeno contraditório, que usa e abusa, instala e depois subverte, os próprios conceitos que desafia" (1991, p.19) - argumenta que, no seio das contradições do autorreflexivo e do histórico, "o que há de mais novo é a constante ironia associada ao contexto da versão pós-moderna dessas contradições, bem como sua presença obsessivamente repetida" (1991, p.13).

É nessa trilha, portanto, de relevo das contradições, em um tempo-espaço contextualizado ${ }^{8}$ que utilizamos o conceito de pósmoderno. É na "presença do passado", enquanto "uma reavaliação

\section{Aspas da autora.}

8 Enfatizamos aqui a ideia de Hutcheon de que o pós-modernismo "não pode ser utilizado como sinônimo para o contemporâneo", já que "não descreve um fenômeno cultural internacional, pois é bastante europeu e (norte- e sul-) americano" (1991, p.20). 
crítica, um diálogo irônico com o passado da arte e da sociedade" (HUTCHEON, 1991, p.20), que relacionamos pós-modernismo à produção literária de Jacques Chessex. Na obra do suíço, o passado não é recuperado melancolicamente, mas memoriado através de seus rastros, na experiência temporal da reelaboração crítica. Ou seja, o passado helvético, desconhecendo silêncios e encarceramentos, é recuperado por Chessex através do processo autoral que Linda Hutcheon resume como o "irônico repensar pósmoderno sobre a história".

De acordo com nossa leitura, o personagem do vampiro construído por Jacques Chessex incarna à perfeição o apagamento de fronteiras entre o histórico e o ficcional. A ideia, acompanhando Linda Hutcheon, é de que, se anteriormente a história era utilizada na crítica de romances, enquanto modelo da visão realista da representação, "a ficção pós-moderna problematiza esse modelo com o objetivo de questionar tanto a relação entre a história e a realidade quanto a relação entre a realidade e a linguagem" (1991, p.34).

Na escritura, a tradução dessa recuperação temporal, ou seja, a tradução dessa memória, é erguida através de apropriações e citações paródicas, através de referências muitas vezes deformadas. Linda Hutcheon qualifica essa tendência literária como "metaficção historiográfica", que, ao incorporar "a autoconsciência teórica sobre a história e a ficção como criações humanas", passa a ser "a base para o seu repensar e sua reelaboração das formas e dos conteúdos do passado" (1991, p.22).

A relação entre tempo vivido e narração é justamente o tema de Paul Ricoeur em seus três volumes de Tempo e narrativa. No segundo volume de Tempo e narrativa (2010), Ricoeur explicita que 
narrar é 'refletir sobre' os acontecimentos narrados, de maneira que "a ficção [...] não cessa de fazer a transição entre a experiência antes do tempo e a experiência depois dele" (2010, p.125). Ou seja, a narrativa não está afastada do vivido, a ele retornando em uma operação de mútua transformação, traduzida como nova "experiência fictícia do tempo" (2010, p.129).

Em seu poder de projetar um mundo, "cada romance diz ao leitor: 'as coisas são mais complicadas do que você pensa'" (KUNDERA, 2009, p.21). É assim que a âncora no tempo, de 1903 a 1920, e no espaço, a pacata cidade suiça de Ropraz, aprisiona o leitor do romance de Jacques Chessex a uma limitação aparentemente confortável. No coração da Europa mergulhada em sua primeira guerra mundial, até mesmo um espaço perdido no continente precisa revolver suas camadas de terra para fazer emergir um significado temporal.

Ao sussurrar que "as coisas são mais complicadas do que você pensa", Jacques Chessex, em boa parte de sua obra, reabre a ferida da memória coletiva negada, apagada, escamoteada. Em Le vampire de Ropraz, o processo de desvelamento da memória coletiva é construído através de elementos como a paródia de artifícios românticos e a ironia como viés de estabelecimento de acasos, estando o primeiro contido no segundo e vice-versa.

Assim sendo, uma leitura possível para Le Vampire de Ropraz é aquela da falência da memória enquanto lugar da expiação histórica. Homenagear o soldado desconhecido não corresponde, em Le Vampire de Ropraz, ao que tradicionalmente seria proposto, ou seja, um ato de respeito e reverência aos que morreram por nós e por nossa pátria e/ou uma advertência ao que não se deve repetir 
jamais. O vampiro-soldado "dorme de um só olho enquanto espera novas noites para correr". E, como nos provam os acontecimentos posteriores aos da Primeira Guerra Mundial, evento abordado no livro de 2007, muitas foram as ocasiões em que a vigília do personagem significou uma cruel condenação à eternidade.

Assim, a imortalidade do vampiro - personagem essencialmente literário - pode exprimir justamente uma crise perene do fazer literário, crise essa compreendida em seu sentido positivo, de renovação. O questionamento, em Jacques Chessex, é sinônimo de ironia, traço marcante em muitos de seus escritos e que ilustra, a contento, sua postura de provocador. No caso de Le vampire de Ropraz é parodiando o estilo romântico que Jacques Chessex tece sua crítica à hipocrisia, aqui tomada tanto em seu sentido artístico, de falsa aparência, quanto em seu aspecto moral, de dissimulação.

Ao recorrer a um personagem tão carregado de significados quanto o vampiro, Jacques Chessex pretende se apropriar de um mito que remonta à memória dos tempos para construir literariamente uma dupla operação relacionada à memória, na dimensão (romântica) da luz e da sombra: iluminar, com seu texto, um fait-divers macabro da ordem do não-dito e render um culto à memória através de sua negação, já que a memória da guerra passa a eternizar-se através do banido, do excluído, que ocupa o espaço do herói nacional.

\section{CONTRASTE ROMÂNTICO ENTRE LUZ E SOMBRA}

A descoberta da subjetividade é marca do espírito romântico. No lugar do homem clássico, guiado por uma razão infalível e resignado com um destino imutável, surge o complexo homem romântico, 
revoltado contra o mundo ou contra a sociedade. Uma leitura simplificada da paródia romântica operada por Jacques Chessex em Le Vampire de Ropraz poderia nos conduzir, assim, à análise do personagem Favez como um anti-herói plano, impossibilitado, portanto, de existir no interstício da imprevisibilidade, na comunhão entre herói e vilão.

Heresias, blasfêmias e conversões são temas das religiões românticas, conforme analisa Octavio Paz, em Os Filhos do Barro (1984). Charles-Augustin Favez, rapidamente enquadrado na categoria de debilitado mental, é construído justamente na fluidez identitária, na ausência de subjetividade que, longe de caracterizar o herói romântico, é um recurso extremante irônico que rima com a análise expandida de Octavio Paz:

Religiões românticas: heresias, sincretismos, apostasias, blasfêmias, conversões. A ambiguidade romântica tem dois métodos, no sentido musical da palavra: um se chama ironia e consiste em inserir dentro da ordem da objetividade a negação da subjetividade; o outro se chama angústia e consiste em deixar cair na plenitude do ser uma gota do nada. A ironia revela a dualidade daquilo que parecia uno, a cisão do idêntico, o outro lado da razão: a quebra do princípio da identidade. A angústia nos mostra que a existência está vazia, que a vida é morte, que o céu é um deserto: a quebra da religião. (1984, p.68).

Se em determinado ponto do romance de Jacques Chessex o vampiro se torna a personalização do medo parece ser porque, violado, se aproxima de todos os estereótipos do feminino romântico: impressionável, sentimental, incoerente e volúvel. A oposição que 
coaduna com uma organização binária do pensamento romântico, explicitada pelo contraste entre luz e sombra na obra chessexiana, é aqui representada pela personagem da misteriosa dama branca. No terreno da ilusão, ou da sombra, a mulher é a imagem platônica projetada na parede da caverna. Ou entre as paredes da prisão.

A dama branca é o duplo de Favez e, ao mesmo tempo, alude a personagens femininos chessexianos que encontramos em alguns de seus outros romances. ${ }^{9} \mathrm{~A}$ identidade da misteriosa dama que visita Favez na cela não será revelada, ela tanto pode ser "uma santa mulher vinda para trazer o conforto de Deus a um proscrito da sociedade" (2007, p.62), quanto uma visitadora de prisões, ou uma histérica, em busca de aventuras.

O jogo de vinculação entre os rituais sexuais e sagrados é recorrente na obra de Chessex. Não por acaso é a dama branca, símbolo do amor fúnebre, duplo do vampiro negro, que pronunciará o "sacramento do monstro", condenando Favez a ser um "vampiro para a eternidade": "Tem o sacramento do monstro, como tem, há dois mil anos, aquele do padre ao altar. Sacerdos eris in aeternum. Vampyrus eris in aeternum." (CHESSEX, 2007, p.77). Eternos serão os sacerdotes e os vampiros. No ritual invertido, é a dama branca que viola o vampiro, bebe seu sangue, profana o seu túmulo. E, assim fazendo, (re)transforma o monstro em humano.

A dama de branco, personagem introduzida por Jacques Chessex no capítulo XI de Le Vampire de Ropraz, faz o contraponto ficcional

9 Em Avant le matin, a jovem mártir é Béatrice Conte, que pratica sexo com os menos favorecidos, a exemplo de sua mentora Canisia Piller, por piedade e para praticar o dom de si mesma. Em La Mort d'un juste, é a elegante Eva Courbet que faz visitas íntimas ao teólogo Aimé Boucher, sedutor hedonista de jovens inexperientes e blasfemador enfeitiçado por seus próprios demônios, em seu refúgio de aposentadoria antecipada. 
com o vampiro, ao mesmo tempo em que estilisticamente parodia o romance gótico. Em Jacques Chessex, o cenário da aparição da dama de branco é a cela de Favez em sua cadeia medieval:

Com o que sonha um vampiro, à noite, trancado a sete chaves em sua cadeia medieval, ele relembra cenas da infância: morrer de fome, sofrer, suportar, se submeter, constantemente querer morrer. Fechado na cela das enegrecidas prisões de Oron, Favez redescobre antigas cenas que ele acreditava poder afastar de sua memória de errante livre. $(2007$, p.57)

Mesmo no texto de sua ficção, em Chessex a memória comunga com o esquecimento, assim como, em uma linha divisória fluida e ambígua entre os dois personagens - Favez e a dama de branco -, o vampiro, não-morto, simbolizaria a memória eterna, a impossibilidade do esquecimento. Na antinomia luz/sombra, o vampiro está ao lado dos símbolos negativos, da escuridão noturna com suas forças maléficas e insegurança moral. Conforme registra Claude Herzfeld, no artigo "Les racines anthropologiques de l'imaginaire dans le Dracula de Bram Stoker"10.

O Drácula de Stoker apresenta uma estrutura antitética que caracteriza o registro diurno do imaginário. As trevas e as imagens de angústia se opõem às imagens de luz, de ascensão e de conquista. Enquanto a noite tem uma existência simbólica autônoma, a luz está ali para valorizar negativamente as trevas. (1993, p.133 - tradução minha)

A luz, nesse trecho do romance de Chessex, em que surge a mulher misteriosa, seria então, aparentemente, essa dama, não de Bram Stoker". In: FAIVRE, Antoine (1993) (org.). Les Vampires - Colloque de Cerisy. Cahiers de I'Hermétisme. Paris: Éditions Albin Michel, p.133-145. 
por acaso de branco. Já na apresentação da personagem, o jogo de luz e sombra parodiado fica explícito. A dama veste-se de branco, misteriosa e muda. O cocheiro porta um uniforme escuro. A crepuscular hora da visita, dezoito horas, é justamente aquela em que o vampiro inicia suas atividades.

A aparente oposição entre o sombrio Favez e a luminosa dama de branco é, entretanto, revertida por Jacques Chessex, em uma deformação que também revela a contestação paródica. Mais do que oposição, podemos falar de forças em conflito, de forma que, em nossa leitura, a mulher de branco pode representar justamente o lado negro que falta a um vampiro débil, através do poder que ostenta. Ela recebe a chave da cela de Favez do vigia carcereiro, certamente pagando por isso. As visitas da misteriosa mulher se repetem, sem que ela tenha receio de penetrar sorrateiramente em um edifício oficial e de seduzir um condenado à reclusão perpétua. Favez tem medo da visitante.

A introdução da dama de branco no enredo parece ser uma piscadela de olho de Jacques Chessex ao próprio gênero gótico, cujo medo é tantas vezes originado justamente a partir do contraste entre luz e sombra. A mulher de branco é, então, aquela que vai violar o vampiro, buscando voluntariamente o estatuto do sombrio, da escuridão. Dessa vez, não é o vampiro que sugará o sangue de sua vítima, mas o contrário: é a vítima que vai esvaziar as veias do algoz e, consequentemente, contaminá-lo. Assim, o vampiro, símbolo do apetite de viver, transfere ao outro essa fome voraz e autodestrutiva. Atormentado por sua finitude, o devorado engendra o devorador, para, em seguida, ser por ele destruído. 


\section{O ESCRITOR-VAMPIRO}

Como já vimos anteriormente, o vampiro do livro Le Vampire de Ropraz não tem o arquétipo do vampiro folclórico, distanciando o romance de uma obra de literatura fantástica. É a simbologia da exclusão, entretanto, que transfigura Charles-Augustin Favez no perfeito vampiro, tese reforçada pela frase que encerra o romance, na qual Chessex retoma a alcunha e faz com que seu protagonista, agora "dormindo" ("de um só olho") em túmulo sagrado, espere por "novas noites para correr".

A exclusão do vampiro é representada visceralmente na indecidibilidade vida-morte, mas alargada para outras dicotomias - luz/escuridão; homem/animal; finitude/eternidade -, que traduzem, conforme analisa Claude Lecouteux em sua História dos vampiros: autópsia de um mito (2005), "a inquietação que nasce de uma ruptura da ordem, de uma fissura, de um deslocamento, de uma contradição" (2005, p.15). Esses "rasgos" estão obviamente relacionados a uma questão ancestral que preocupa os homens, a curiosidade sobre o que há e o que acontece após a morte, esgarçada a ponto de criar um ser capaz de transitar entre dois mundos, não sendo nem vivo nem morto.

É também na ordem da ruptura e da transcendência que, de uma maneira geral, Jacques Chessex prefere enquadrar a sua obra. A partir dessa ideia, podemos comparar o autor ao próprio personagem. Ao gosto de Flaubert, escritor de sua predileção e sobre o qual publicou, em 1991, o ensaio Flaubert ou le désert en abîme, Jacques Chessex escreve em Le Vampire de Ropraz: "[...] vampiro de Ropraz, meu duplo, meu irmão!" (2007, p.78). Duplo na exclusão e fraterno no abjeto, este último conceituado por Julia 
Kristeva, em seu Pouvoirs de l'horreur: essai sur l'abjection ${ }^{11}$ (1980), como "aquilo que perturba a identidade, o sistema, a ordem. Aquilo que não respeita as fronteiras, as posições e as regras. 0 entre-dois, o ambíguo, o composto." (1980, p.12, tradução minha).

Assim como um vampiro, Chessex sabe que incomoda, mas também sabe o que representa. Em reportagem ao jornal suíço "Le Messager", em 15 de junho de 2007, na ocasião de lançamento do romance Le Vampire de Ropraz, a foto que ilustra a matéria tem como cenário o cemitério de Ropraz, com a legenda: "O escritor Jacques Chessex, 73 anos, mora em Ropraz há cerca de trinta anos, em frente ao cemitério que o fascina" ${ }^{12} \mathrm{O}$ cemitério, o mesmo em que está enterrada Rosa Gilliéron, era um local constantemente visitado pelo escritor, que na mesma reportagem declara: "Esse livro, eu poderia tê-lo escrito há quarenta anos. Quando comecei a perambular em Ropraz, antes mesmo de morar na cidade, já ouvi a história do vampiro". Curiosamente, é hoje o mesmo cemitério em que está enterrado o corpo de Jacques Chessex, falecido em 2009.

Transformar o fait divers, o rumor, em romance alinhava algumas obras de Jacques Chessex, livros em que os arquivos da memória helvética parecem ter sido remexidos, apropriados e regurgitados como instrumentos de recusa à vontade de esquecimento. São obras que reformulam a memória, a relação do homem com o passado, designada por Paul Ricoeur, em A memória, a história, o esquecimento (2007), como uma relação em que "[...] boa parte da busca do passado se encaixa na tarefa de não esquecer" $(2007$, p.48).

11 KRISTEVA, Julia (1980). Pouvoirs de l'horreur: essai sur l'abjection. Paris: Éditions du Seuil.

12 In http://lemessager.ch/Archives/messager07/Juin\%2007/MESS\%2015-06-07/ME15-06-01.pdf Acesso em 22.Jan.2019. 
É no sentido dessa busca-tarefa que, em Chessex, o espaço assume real importância, alinhando o escritor, no território construído a partir da polaridade reclusão-abertura, ao vampiroexcluído, ao vampiro-testemunha e ao vampiro-ruptura, todos eles relacionados ao esquecimento. Ao discorrer sobre "reflexividade" e "mundanidade", sintagmas integrantes do tema da memória e da reminiscência, Paul Ricoeur admite:

Não nos lembramos somente de nós, vendo, experimentando, aprendendo, mas das situações do mundo, nas quais vimos, experimentamos, aprendemos. Tais situações implicam o próprio corpo e o corpo dos outros, o espaço onde se viveu, enfim, o horizonte do mundo e dos mundos, sob o qual alguma coisa aconteceu. (2007, p.53)

No bojo do "processo memorial", fazem parte da reminiscência, portanto, diários íntimos, memórias e antimemórias, autobiografias, "em que o suporte da escrita confere materialidade aos rastros conservados, reanimados e novamente enriquecidos por depósitos inéditos" (RICOEUR, 2007, p.56). As palavras do filósofo nos remetem, assim, ao processo memorial de Jacques Chessex, o "escritor de Ropraz", para compor sua obra. Além do prefácio-paródia, no qual o narrador anuncia a veracidade dos fatos relatados, no espaço biográfico chessexiano encontramos diversas entrevistas, como a concedida ao jornal suíço "Le Messager", em 15 de junho de 2007, ou à jornalista Geneviève Bridel, publicada no livro anteriormente citado, ou ainda a autoindagação que resultou no livro póstumo L'Interrogatoire, de 2011.

$\mathrm{Na}$ entrevista ao jornal, Jacques Chessex aponta que as principais informações para a escritura de Le Vampire de Ropraz 
vieram de fontes orais da cidade de Ropraz. Na mesma entrevista, o autor revela que sabe o nome do verdadeiro culpado dos crimes de Ropraz e que possui a arma do crime. A confluência da questão espaço-memória não é em absoluto ignorada pelo escritor suíço. Em Jacques Chessex - Transcendance et transgression, ele diz:

Eu me dou conta de que a Suíça, que em muitos aspectos me contraria - sua frigidez política, sua recusa em integrar a União Europeia etc - é um formidável reservatório de imagens. A Suíça é um mundo plástico sedutor [...]. Este país manifesta uma audácia, uma inteligência plástica, poética e arquitetônica, uma inventividade, que contrastam expressivamente com sua pusilanimidade política e intelectual de hoje. (BRIDEL, 2002, p.152-153 tradução minha)

Jacques Chessex, na citada passagem, retomando a "materialidade dos rastros conservados, reanimados e novamente enriquecidos por depósitos inéditos", mencionada por Paul Ricoeur, revela sua profunda consciência pelo que pode ser compreendido como o patrimônio cultural de sua pátria, patrimônio este que inclui, ao lado de nomes ilustres e riquezas iconográficas, o posicionamento político e intelectual dos suíços. E é nesse sentido que o escritorvampiro, aquele exigido pelo narrar enquanto experiência de certa forma de viver, precisa fazer emergir o não-dito. Em Le Vampire de Ropraz, o não-dito é a identidade do necrófilo. Em Ropraz, a imagem indefectível é deslocada da verdadeira identidade do assassino para a agilidade na solução do caso - e, nesse sentido, qualquer hipótese convincente basta como verdade.

Em outro sentido, o silêncio da ironia contém uma dimensão julgadora que induz à "percepção simultânea do dito e do não dito" 
(HUTCHEON, 2000, p.66). Ou melhor, como amplia Linda Hutcheon, "o poder do não dito de desafiar o dito é a condição semântica que define a ironia" (2000, p.91). Para tanto, ou seja, para que a ironia ocupe esse espaço semântico, é preciso que ela inclua atitude e julgamento compartilhados entre o ironista e o interpretador. É nesse compartilhamento (ou em sua ausência) que a ironia produzirá seus efeitos - do prazer à raiva.

No espelho da intenção do ironista está o ponto de vista do interpretador da ironia, cuja afetividade varia do prazer à dor, da diversão à ira. Em críticas publicadas em jornais suíços na ocasião do lançamento de Le Vampire de Ropraz, a ironia estilística de Jacques Chessex é ignorada, enquanto a ênfase se situa na questão da veracidade dos fatos relatados. Em nossa visão, a falha em captar a ironia - ou a opção em ignorar o recurso - por essa plateia de críticos-leitores-interpretadores de Le Vampire de Ropraz situase justamente na permanência da neutralidade, que infere tanto o "lavo minhas mãos" quanto o "não me concerne".

Nesse sentido, a recorrência em citar o fait divers é reveladora, já que se trata, por definição, de um tipo de assunto jornalístico inclassificável, que não se inclui em nenhuma outra editoria. Assim sendo, estamos tratando de um fato jornalístico cuja própria definição sugere marginalidade e superficialidade. São eventos que, aparentemente, não têm efeito sobre o funcionamento da sociedade, apenas testemunhando sua face maldita. Essa é a compreensão do senso comum sobre a rubrica.

O escândalo e o bizarro estão relacionados ao entretenimento, à diversão, e não ao que deve ser levado a sério. Assim, ao repetirem que o livro de Jacques Chessex é "baseado em fatos reais" da ordem 
do fait divers, os críticos do jornalismo literário preservam essa característica do alheamento (neutralidade), que naturalmente induz à exclusão. Nesse caso, interpretar o romance de Jacques Chessex "ao pé da letra" é retirá-lo do jogo da ironia, exercendo, assim, a premissa de interpretador. "Afinal, a responsabilidade última de decidir se a ironia realmente acontece numa elocução ou não (e qual é o sentido irônico) é apenas do interpretador" (2000, p.74), afirma Linda Hutcheon, para quem a ironia pode ou não ser intencionada pelo ironista, ao passo que é sempre um caso de interpretação e atribuição.

A partir do exposto, podemos concluir que, para Jacques Chessex, revisitar o sombrio e o "esquecido" da sua história biográfica e patrícia é, ao mesmo tempo, transgressão e abertura. Uma reação a uma "espécie de nanismo" a que a Suíça estaria condenada, pela falta de audácia em romper as barreiras geográficas e mentais (BRIDEL, 2002, p.163). A imagem a que o escritor recorre, remontando a um cartaz visto no período da Segunda Guerra, é aquela do fantasma com o dedo sobre a boca, dizendo: "quem não sabe se calar prejudica o país". Tal imagem é relacionada por ele, mais uma vez, à oposição claro-escuro: "Eu também achava estranho o obscurecimento imposto naqueles anos. Tudo era azul e negro, não havia iluminação externa, a noite estava em todos os lugares" (BRIDEL, 2002, p.41).

Para romper a noite eterna do esquecimento imposto, aquele que seria equivalente, na classificação de Paul Ricoeur, ao esquecimento por apagamento de rastros ${ }^{13}$, Jacques Chessex põe em cena o seu duplo, o vampiro de Ropraz, cuja imortalidade representa a arte:

13 Paul Ricoeur reconhece, em A memória, a história, o esquecimento, duas grandes figuras do esquecimento: o esquecimento por apagamento de rastros (profundo) e o esquecimento de reserva (reversível). 
"Há menos de morte quando há mais de arte. [...] Isso é certo. Há uma espécie de perfusão da eternidade pela obra de arte, pelas elevações onde arde essa soberba chama que encontramos em uma pintura, uma obra, um poema, um ensaio" (BRIDEL, 2002, p.194).

Negociação entre apagamento e conservação. Essa é a leitura que Roger Bozzetto faz do vampiro moderno no artigo "Le trésor du vampire". ${ }^{14}$ Para Bozzetto, um dos "tesouros" do vampiro moderno é que ele fala de si, descortina sua biografia e segredos, compartilhando sua experiência de vida. Paralelamente, a visão de mundo do vampiro moderno evolui com o tempo, assim como sua força física. Em jogo, está a busca primordial: "Além disso, assim como os humanos, os vampiros modernos estão em busca de seu criador, à procura de suas origens, de um segredo: encontrar aquele que sabe para enfim saber (Lestat) ou, como Timmy Valentine, buscar uma plenitude perdida" (BOZZETTO, 1993, p.149, tradução minha).

Para esse vampiro moderno, a busca de suas origens orienta o herói a remontar um tempo mítico, naquela nesga que Ricoeur chama de negociação entre memória e esquecimento. Para o vampiro de Ropraz, não é exatamente um tempo imemorial que é buscado, mas outra forma de identidade, aquela que liga o mito e o homem, permitindo uma reflexão sobre nosso estatuto original. Surgindo como nossa face escondida, jamais refletida no espelho, o vampiro de Ropraz representa, portanto, uma busca autoral pelo velado, pelo encoberto, que inclui o medo traduzido em reescritura, a imortalidade traduzida em arte e a plenitude perdida traduzida em preservação de rastros. 


\section{REFERÊNCIAS}

BENJAMIN, Walter (1989). Obras escolhidas III. São Paulo: Brasiliense.

BOZZETTO, Roger (1993). "Le trésor du vampire" In: FAIVRE, Antoine (org.). Les Vampires - Colloque de Cerisy. Cahiers de I'Hermétisme. Paris: Éditions Albin Michel, p.146-154.

BRIDEL, Geneviève (2002). Jacques Chessex - Transcendance et transgression, entretiens avec Geneviève Bridel. Lausanne: La Bibliothèque des Arts.

CENDRARS, Blaise (2003). Morravagin: romance. O fim do mundo filmado pelo anjo Notre-Dame. Dorothé de Bruchard (Trad.). Carlos Augusto Calil (Coord.) São Paulo: Companhia das Letras.

CESAR, Constança Marcondes (2011). "Temporalidade e literatura". In: PAULA, Adna Candido de; SPERBER, Suzi Frankl (Org.). Teoria literária e hermenêutica ricoeuriana - Um diálogo possível. Dourados, MS: UFGD, p.165-175.

CHESSEX, Jacques (1991). Flaubert ou le désert en abîme. Paris: Grasset. (1996). La Mort d'un juste. Paris: Grasset.

(2006). Avant le matin. Paris: Grasset. (2007). Le Vampire de Ropraz. Paris: Grasset.

(2009). Un juif pour l'exemple. Paris: Éditions Grasset \& Fasqualle. (2011). L'Interrogatoire. Paris: Grasset.

ECO, Umberto (2003). "A função dos intelectuais". Revista Época, fev.03. In http://revistaepoca.globo.com/Revista/Epoca/0,,EDR55351-6075,00.html Acesso em 29.Jan.2019.

FAIVRE, Antoine (Org.) (1993). Les Vampires - Colloque de Cerisy. Cahiers de I'Hermétisme. Paris: Éditions Albin Michel.

HUTCHEON, Linda (1991). Poética do pós-modernismo: história, teoria, ficção. Ricardo Cruz (Trad.). Rio de Janeiro: Imago.

KRISTEVA, Julia (1980). Pouvoirs de l'horreur: essai sur l'abjection. Paris: Éditions du Seuil.

KUNDERA, Milan (2009). A arte do romance. Teresa Bulhões Carvalho da Fonseca (Trad.). São Paulo: Companhia das Letras. 
LECOUTEUX, Claude (2005). História dos vampiros: autópsia de um mito. Álvaro Lorencini (Trad.). São Paulo: Editora Unesp.

PAZ, Octavio (1984). Os Filhos do Barro: do romantismo à vanguarda. Olga Savary (Trad.). Rio de Janeiro: Nova Fronteira.

RICOEUR, Paul (2007). A memória, a história, o esquecimento. Alain François (Trad.). Campinas, SP: Editora da Unicamp. (2010). Tempo e narrativa - A configuração do tempo na narrativa de ficção. Vol. 2. Márcia Valéria Martinez de Aguiar (Trad.). São Paulo: Editora WMF Martins Fontes. 


\section{MULHERES MONSTRUOSAS: O CTÔNICO E 0 SELVAGEM EM CARMILLA, DE LE FANU}

Marina Pereira Penteado (FURG)

Recebido em 17 mar 2019. Marina Pereira Penteado é Doutora em Literatura Aprovado em 24 mai 2019. Comparada pela Universidade Federal Fluminense e Professora Substituta do Instituto de Letras e Artes da Universidade Federal do Rio Grande

Resumo: O presente trabalho propõe uma discussão a respeito da representação demoníaca das mulheres, através de aspectos que são normalmente ligados ao próprio feminino, na novela Carmilla: a vampira de Karnstein, de Sheridan Le Fanu. Com base em estudos que analisam a perda da autonomia da mulher sobre seu próprio corpo, o primitivo e animalesco e suas representações na literatura, além de estudos que debatem a monstruosidade percebida na figura da mulher e em quase tudo que é ligado ao feminino, busco fazer uma reflexão sobre como a incorporação do selvagem, do ctônico e do dionisíaco tomam forma em Carmilla, e até que medida esses aspectos são utilizados para justificar a morte da vampira.

Palavras-chave: Vampiros; Natureza ctônica; Mulheres monstruosas.

Abstract: This article proposes a discussion on the daemonic representation of women, through aspects generally associated with the feminine itself, in Carmilla, by Sheridan Le Fanu. Taking into account 
studies that analyze women's loss of autonomy over their own bodies, the primitive and animalistic representations in literature, as well as studies that discuss the monstrosity perceived in women and in everything connected to the feminine, I aim to analyze how the incorporation of the wild, the chthonian and the Dionysian take place in Carmilla, and to what extend this aspects are used to justify the persecution and death of the vampire.

Keywords: Vampires; Chthonian nature; Monstrous women.

Ao lado de "O vampiro" (1819), de John Polidori, e Varney the Vampyre: or the Feast of Blood (1840), de James Malcolm Rymer, Carmilla - a vampira de Karnstein, do irlandês Sheridan Le Fanu, é uma das primeiras histórias de vampiros escritas em língua inglesa. Publicada em formato de folhetim entre 1871 e 1872, além de ter exercido uma influência direta na ficção de Bram Stoker e no desenvolvimento do mito moderno do vampiro, Carmilla ainda instiga debates sobre a representação demoníaca da mulher na era Vitoriana e se mantém como uma referência literária importante para estudos que lidam com as relações entre mulheres e o feminino monstruoso. Assim, neste trabalho, proponho uma análise dessas questões através da discussão sobre o medo do ctônico, do dionisíaco e do selvagem percebidos na figura da vampira que dá nome a história, que precisa ser destruída a qualquer custo - e de preferência pelo sexo masculino -, a fim de reestruturar a ordem que a narrativa Vitoriana exige.

Escrito pouco mais de cinquenta anos antes de Carmilla, o poema "Christabel" (1816), de Samuel Taylor Coleridge, apresenta uma história parecida, na qual uma mulher, Geraldine, após escapar 
de homens que a haviam raptado, encontra Christabel, que a recebe em seu castelo. Embora Geraldine não seja chamada de vampira -e muito menos de uma vampira lésbica - na narrativa, ela claramente assume tal papel, e é representada, como Camille Paglia (1991) observa, como uma força demoníaca da natureza, aspecto que é, em certa medida, recuperado por Le Fanu. "Christabel" traz a mulher como um perigo, como um agente disruptivo do mundo apolíneo de ordem dos homens, uma vez que nele tudo que é relacionado ao feminino é perigoso.

Paglia, em seu estudo Personas Sexuais (1991), chama atenção para o fato de Coleridge ver "o horror ctônico na natureza" ${ }^{1}$, criando Geraldine como um demônio de tal natureza. Para a autora, "Christabel", seguindo o molde de outros escritos anteriores de Coleridge, parece deixar de fora a ortodoxia cristã e se infiltrar no submundo da cultura ocidental e sua mistura pagã de hermetismo, alquimia e astrologia. A incompletude do poema, para Paglia, está justamente ligada ao fato de Coleridge se aproximar da natureza e do pictorialismo pagão enquanto se afasta da ortodoxia cristã. Desta forma, a autora conclui que "Coleridge não poderia transformar sua saga demoníaca em uma parábola de redenção cristã"2 (PAGLIA, 1991, p.340), em vez disso, ele retorna a psique para um mundo primitivo e maligno na incompletude de seu poema.

Embora também com uma ideia de natureza como algo implacável, Le Fanu, por sua vez, tenta amenizar o maligno em Carmilla. Onde a heterossexualidade e a masculinidade parecem

1 "Geraldine, the green snake who strangles the dove, is the deamon of chthonian nature, trampling man in her triumph of the will." (PAGLIA, 1991, p.326)

2 "Coleridge could not turn his daemonic saga into a parable of Christian redemption." (Tradução minha). 
falhar em Coleridge, em Le Fanu elas recebem força, em uma tentativa de destruir o primitivismo que uma força demoníaca da natureza poderia causar. Com a adolescente Laura como narradora, a novela é ambientada em um castelo na Estíria, no qual Laura vive com seu pai, um inglês aposentado do exército austríaco e desatento em relação a sua filha e a nova hóspede. A história de Laura inicia com a lembrança de um sonho sobre a aparição da figura de uma bela jovem (Carmilla) em seu quarto, que a deixa com um susto e a sensação de "que duas agulhas haviam sido enfiadas" em seu peito (LE FANU, 2010, p.42). A partir de então, a narrativa se desenrola como um bom romance Vitoriano, baseada em provas e na ciência para tentar explicar eventos que pareceriam bastante duvidosos, caso não houvesse uma cópia do relatório da Comissão Imperial com os testemunhos de todos os homens envolvidos na morte da vampira para comprovar o ocorrido ${ }^{3}$.

Escrito em um período no qual a homossexualidade era considerada crime, a narrativa de Le Fanu, embora exija uma punição para os aspectos não aceitos pela sociedade Vitoriana, se destaca por ser a primeira narrativa sobre vampiras lésbicas. A natureza demoníaca que Paglia observa em Coleridge, também surge em Carmilla, causando uma tensão entre a dualidade apolínea e a dionisíaca representada, de um lado, pelos ingleses e, de outro, pela vampira estrangeira e lésbica. Com cenas de adoração e sentimentalismo entre as protagonistas, nas quais a vampira é quem quase sempre se declara, expressando sentimentos tais como "jamais me apaixonei por quem quer que seja, e jamais me

3 "Meu pai possui uma cópia do relatório da Comissão Imperial, com assinatura de todos os que presenciaram os ritos, atestando a veracidade dos depoimentos." (LE FANU, 2010, p.140) 
apaixonarei [...] a menos que seja por ti" (LE FANU, 2010, p.82), Laura parece mais contida, ainda presa ao mundo apolíneo, embora se mostre não tão ingênua quanto seria de se supor. A narradora declara se sentir "atraída por ela [Carmilla]", mas com "uma certa repulsa" (LE FANU, 2010, p.62), percebendo as aproximações de Carmilla, muitas vezes, como "estranhos acessos de adoração" (LE FANU, 2010, p.93), no que parece uma hesitação entre seguir seus impulsos, ouvir sua intuição - que avisa ter algo de estranho na situação -, ou agir com decoro.

O aspecto homossexual da obra é percebido por vários críticos como havendo sido, possivelmente, também influenciado pela história da Condessa Elizabeth Báthory de Ecsed (1560 - 1614), húngara que matou cerca de seiscentas jovens com o intuito de usar o sangue dessas mulheres para preservar sua beleza. Carmilla incorpora a monstruosidade da "condessa de sangue", que além de matar jovens moças, ainda apresentava traços homossexuais, como os sugeridos pelos relatos nos quais eram registradas cenas tais como "a condessa mordendo a carne das jovens, a colocação dos corpos semimortos das moças nuas e ensanguentadas dentro de uma banheira na qual Báthory se banhava" (SILVA, 2010 p.31), entre outras. Monstruosidade essa, também encontrada em figuras muito mais primitivas e anteriores, que foram importantes para a construção do mito do vampiro e, mais especificamente, da mulher como vampira.

Se a capacidade de gestação fez com que a mulher fosse muito mais associada à natureza do que o homem, os aspectos misteriosos, selvagens e demoníacos da natureza também foram muito mais relacionados a ela. Como Alexander Meireles da Silva 
comenta, na introdução da edição brasileira da obra de Le Fanu, no processo de associação da mulher à natureza, "o homem se definiu como racional e apolíneo, e a mulher como irracional, instintiva, ligada ao inconsciente, ao sonho e à Lua." (2010, p.18). Com uma ligação com a vida e a morte, simbolizada pela própria menstruação, a figura da mulher acabou sendo relacionada à destruição e a criação, alimentando as primeiras representações de vampiros. De Lilith, mãe dos demônios, passando por Lamia, Strix, Langsuyar, Tlahuelpuchi e a deusa hindu Kali, o ponto em comum dessas narrativas de mulheres que sugam o sangue de crianças assim como Carmilla, que se alimenta de jovens meninas - parece ser a maternidade e essa subversão do papel da mãe, em que a mesma que deu vida, termina por destruí-la de alguma forma.

Esse ciclo de vida e morte, tão ligado às próprias fases lunares, é o ponto de partida, tanto do poema de Coleridge, no qual "A lua está atrás, e está cheia”4 ( 2009, p.68) quando Geraldine surge, quanto na novela de Le Fanu. Embora quase todas as histórias de vampiros recuperem a imagem da lua em algum momento, em Carmilla, ela parece ter um significado específico interessante. A chegada da carruagem que traz a hospede é precedida pela fala de Mademoiselle De Lafontaine, uma das governantas de Laura, que repassa seu conhecimento sobre a lua e suas influências da seguinte maneira:

O efeito da lua cheia, com todo aquele brilho, era múltiplo. Atuava sobre os sonhos, atuava sobre a loucura, atuava sobre os aflitos; exercia influências físicas fantásticas sobre a vida. [...] Esta noite a lua ela dizia - está plena de força odílica e magnética...

4 "The moon is behind, and at the full." (Tradução minha) 
e veja, atrás da senhora, todas as janelas do schloss brilham e cintilam com esse esplendor prateado, como se mãos invisíveis houvessem acendido luzes nos quartos, para receber convidados feéricos. (LE FANU, 2010, p.49)

Normalmente relacionada aos aspectos de força, potência, nutrição e criação, além de ser associada, na maior parte das culturas, ao feminino, a lua cheia que provoca ações intensas na natureza, em Le Fanu, parece enfatizar um efeito dual. Ao mesmo tempo em que a luminosidade seduz, ela também amedronta com sua natureza "magnética". Tal aspecto é possível de ser observado em outras cenas, como quando Laura fala sobre a beleza de Carmilla ser realçada com a luz da lua cheia ${ }^{5}$, dando uma ideia de uma espécie de feitiço, por exemplo. Na narrativa, é no momento no qual o disco lunar está visível à noite e completamente iluminado que a chegada da carruagem de Carmilla também acontece. A força lunar e sua energia "feérica", advertida pela supersticiosa Mademoiselle De Lafontaine, além de iluminar o acidente, quando os cavalos caem ao avistar uma velha cruz de pedra à beira da estrada, fascinam quem está assistindo a cena.

Com a culpa do acidente recaindo no símbolo cristão, e não na lua, a novela narra a primeira tentativa de proteção que a família de Laura recebe contra forças supostamente demoníacas que adentravam seu território, delimitando a partir daquele momento que essa proteção vem da religião. A ameaça, que não é apenas estrangeira, mas vem também da mulher, é iluminada por um dos maiores símbolos feminino e marca a chegada de três figuras que precisam ser destacadas. Assim como a figura arquetípica da Deusa Tríplice Lunar e suas três faces:

5 Laura exclama: “Como era bela ao luar!” (LE FANU, 2010, p.82) 
donzela, mãe e anciã - todas vinculadas ao inconsciente feminino -, a novela traz Carmilla, a mãe e uma mulher negra. A escolha da lua, de uma fase lunar específica e da personagem que será central na cena reforçam a importância do símbolo utilizado. Em relação às três fases citadas, temos na novela: Carmilla, a donzela quase desmaiada; a mãe, "uma mulher vistosa, considerando a idade [...] pálida [...] com fisionomia altiva e autoritária" (LE FANU, 2010, p.51-52), que é quem conduz a conversa com os habitantes do castelo; e uma mulher que parece controlar a cena,

negra, de aspecto assustador, portando uma espécie de turbante colorido, observando o tempo todo da janela da carruagem, sacudindo a cabeça e rindo e zombando da situação, com um olhar brilhante e arregalado, os dentes cerrados (LE FANU, 2010, p.57).

Das três figuras, acompanhadas de lacaios e cavaleiros que inspiram pouca curiosidade na narrativa, apenas duas são notadas por todos os personagens: a mãe - que também é arquétipo predominante da fase da lua cheia - e a filha, que pouco interage, pois estava "aparentemente sem vida" (LE FANU, 2010, p.51). A mulher negra, por sua vez, só é percebida por Mademoiselle De Lafontaine. A figura arquetípica da anciã, normalmente ligada à cor preta e descrita como sendo alguém que supervisiona e cuida as outras duas figuras, mantendo o equilíbrio, igualmente "pode parecer terrível, uma vez que ela é o portal para morte. No entanto, ela pode ser vista também como o psicopompo que guia e indica o caminho para a nova vida"6 (FARRAR, 2012, Ed. Kindle).

6 "[she] can seem terrible, because she is the gateway to Death. But she is also the Psychopompos who guides us through it, pointing the way to the new life." (Tradução minha) 
A figura da mulher negra, de fato, proporciona a ideia de que, além dela possivelmente também ser uma vampira - e talvez a mais macabra e antiga das três -, ela ainda pode ser uma espécie de guia. Ao estar oculta sob a luz da lua cheia, reforçando a referência arquetípica da figura que ela representa, a personagem ainda aponta para questões coloniais bastante presentes, em geral, na literatura Vitoriana, e que, por sua vez, também costumam trazer tal figura para representar o monstruoso da história. No caso da narrativa de Le Fanu, essa mulher parece incorporar todo o ctônico, como uma espécie de força da natureza primitiva e selvagem, além de representar uma das faces de Carmilla, a donzela que chega ao shloss desmaiada e que em um dos seus acessos de adoração com Laura exclama "meu coração selvagem sangra" (LE FANU, 2010, p.67 - Grifo da autora).

O fato de os demais personagens não notarem haver outra figura dentro da carruagem, muito menos se questionarem sobre a situação esquisita envolvendo uma mãe que não concede sua identidade, de onde vem ou para onde vai, e que deixa a filha por três meses aos cuidados de estranhos por estar com pressa para um compromisso, é associada, possivelmente, a alguma espécie de magia ancestral na narrativa, despertada pela lua. Mademoiselle De Lafontaine, a única personagem que se permite acreditar em fantasmas e superstições, é também a única que percebe a face monstruosa de dentro da carruagem. No entanto, em sua ingenuidade, ela presta mais atenção na beleza de Carmilla do que na figura assustadora. Ao dizer "é simplesmente linda" (LE FANU, 2010, p.37) ao se referir à garota, é como se a esquisitice dos acontecimentos fosse obliterada pela beleza da jovem, sugerindo 
que talvez se Carmilla parecesse menos bonita, o perigo teria sido mais óbvio. Desta forma, como se todos estivesse sob algum feitiço, a presença da figura negra sugere que o que está prestes a acontecer não é nada natural, mas que, ao mesmo tempo, só pode vir da natureza.

Isolada do mundo e na ausência da figura materna, Laura não possui vínculos com figuras femininas fortes, embora deseje, como é possível observar pela insistência para que seu pai aceite Carmilla em seu castelo, e mesmo anteriormente, em sua frustração por saber que a sobrinha do general Spielsdorf havia cancelado a visita que ela esperava há meses. Apenas com a companhia do pai e de duas governantas, a narradora percebe na chegada da jovem a possibilidade de desenvolver uma relação mais íntima com alguém. O que Laura narra, a partir da chegada da vampira, por sua vez, longe dos olhares adultos e supervisionais dos outros integrantes do schloss, é um dos pontos fortes da história de Le Fanu, que se destaca por criar um universo só das duas personagens, no qual Carmilla, uma criatura que parece, a princípio, livre das amarras patriarcais da sociedade Vitoriana, concede um pouco da mesma liberdade à narradora, que a recebe com um misto de encanto e receio.

Se normalmente as personagens mulheres eram controladas por homens nas narrativas de vampiros, nas quais eles agiam como seus mestres, em Le Fanu, caso Carmilla responda a alguém, é provavelmente à sua mãe ou à mulher negra misteriosa da narrativa. Como Nina Auerbach observa em seu estudo Our Vampires, Ourselves (1995), "Carmilla não é produto de algum mestre, mas o espírito de uma comunidade feminina dúbia que pode ser quem a criou ou 
pode apenas ser composta por suas aliadas, mas que tem um poder percebido apenas pelas mulheres"7 (AUERBACH, 1995, p.40).

As três figuras, além de interagirem de uma maneira singular entre si, ainda parecem compartilhar da natureza ctônica que irá ameaçar a ordem Vitoriana. Desta forma, as características demoníacas que Mademoiselle De Lafontaine nota na mulher negra também estão em Carmilla e na figura da mãe, embora camufladas em uma aparência mais cativante. Laura nota que "havia algo de distinto e mesmo imponente no semblante e na aparência daquela dama" (LE FANU, 2010, p.53), ao se referir a mãe de Carmilla, sugerindo haver na magnitude específica da personagem algo ancestral e feminino que não parece fazer parte daquele universo Vitoriano racional.

Ainda sobre a figura negra, Auerbach a percebe como "o próprio diabo na forma de uma sacerdotisa voodoo; suas associações exóticas, raciais e espirituais, insinuam uma magia feminina que ultrapassa a extensão geográfica oriental e dominantemente masculina de Byron ou a tradição nórdica de Varney"8 (AUERBACH, 1995, p.40). A mulher de aspecto assustador, que parece uma espécie de Baba Yaga das vampiras - alguém que está ali para aconselhar as duas mais jovens é sem dúvida uma força implacável, ctônica. Tal aspecto também é percebido por Claude Lecouteux, que identifica Carmilla como uma narrativa que se insere "em uma longa linhagem de crenças e tradições que remonta às bruxas e magas da Antiguidade clássica" (2003, p.21), reforçando esse aspecto do

7 "Carmilla is not the product of a single maker's potency, but the spirit of an elusive female community who may be her makers or merely her condeferates, and whose power only women perceive." (Tradução minha)

8 "the devil herself in the form of a voodoo priestess; her exotic associations, racial and spiritual, hint at a geographic range of female magic beyond Byron's male-ruled Orient or Varney's Nordic lore". (Tradução minha) 
feminino demoníaco na obra. O que a personagem negra sugere, no final, é que ela é o lado mais selvagem, estritamente ligado à natureza das mulheres, aquele que sai à noite e suga o sangue das moças camponesas sem que ninguém veja.

Além de nenhuma figura mais velha e autoritária retornar para controlar Carmilla na novela, as personagens femininas ainda parecem se unir de uma maneira que os homens que as observam não conseguem perceber, ou penetrar, como Auerbach nota ${ }^{9}$, tornando-as ainda mais demoníacas. Carmilla invade o castelo do pai de Laura e o tira da posição de poder e dominação, criando uma narrativa que pertence apenas às mulheres, e mais especificamente a ela e Laura. A ausência de nome do pai da narradora já é significativa, uma vez que ele é uma das figuras centrais da novela e que aparece do início ao fim. Sempre sendo referido como "pai", enquanto até a mãe morta de Laura recebe uma identidade mais consistente - sabemos que ela é descendente dos Karnstein, mesma família de Carmilla -, apenas sabemos que ele é inglês.

Carmilla não faz de Laura apenas sua presa, mas estabelece uma relação mais intensa, que passa completamente despercebida pelo pai e pelos os outros integrantes do schloss. Sua relação com Laura não é apenas para saciar seus desejos, para isso, ela se alimenta de garotas camponesas da região. Em Laura, alguém da mesma classe social sua, a vampira se identifica de uma maneira mais profunda e permite que sua amante sobreviva por muito mais tempo que as outras vítimas. No entanto, da mesma forma que a construção das duas personagens se destaca por elas serem criadas em um espaço impenetrável - a princípio

9 "(...) women in Carmilla merge into a union the men who watch them never see." (AUERBACH, 1995, p.43) 
- pelo masculino, ambas também são dividas em opostos, como já citado: Laura, a apolínea, e Carmilla, a dionisíaca. Tal divisão, que justifica a destruição do lado monstruoso, é pautada na cientificidade dos homens da narrativa, que explicam até mesmo o comportamento de cortejo de Carmilla como sendo algo comum em alguns vampiros ${ }^{10}$, de forma a neutralizar a atração entre as duas personagens.

A tentativa de explicar racionalmente todos os acontecimentos, dos relatos dos médicos às citações de livros, entra em conflito com tudo que a vampira parece trazer à narrativa. A insuficiência da ciência e da racionalidade para explicar o desaparecimento de Carmilla dentro do castelo no final da novela é um exemplo. Após diversas conjecturas sobre o ocorrido, o pai de Laura chega a uma conclusão bastante falha de que só pode ser o sonambulismo que fez a garota desaparecer de seu quarto, conclusão da qual ele ainda se vangloria ao dizer "devemos nos felicitar, porque a explicação mais natural do ocorrido não implica entorpecente, arrombamento de fechadura, ladrão, veneno, ou bruxas... nada que possa assustar Carmilla, ou qualquer um de nós" (LE FANU, 2010, p.101). É o alívio de criar uma explicação racional para não precisar lidar com o que existe de não compreensível e assustador na natureza de Carmilla, mesmo que a explicação faça pouco sentido.

A vampira traz o indomável da natureza, se apresentando como uma força perversa e feroz, ao mesmo tempo em que também é

10 "O vampiro tendo a se fascinar por determinadas pessoas, com grande ardor, algo similar à paixão carnal. Nesses casos o vampiro demonstra paciência e ardis inesgotáveis, visto que o acesso ao objeto desejado, por vezes, apresenta uma centena de obstáculos. O vampiro não descansa enquanto não sacia a paixão e drena a vida da vítima cobiçada. Mas, ao mesmo tempo, sabe guardar e postergar o prazer assassino, com o refinamento de um epicurista, intensificando tal prazer por meio de abordagens sutis que caracterizam o amor cortês." (LE FANU, 2010, p.143-144) 
maternal. Tal força, a princípio, é explicada como inabalável, como quando Carmilla zomba dos amuletos de proteção compostos por longas tiras de pergaminho, contendo códigos e diagramas cabalísticos, comprados por ela e Laura de um andarilho. Ela pergunta: "[...] você acredita que espíritos do mal se assustam com pedacinhos de fita, ou com perfumes criados no laboratório de um químico?" (LE FANU, 2010, p.92). O que ela deixa explícito é que sua força, que como a de Geraldine é demoníaca e de natureza ctônica, não pode ser diminuída ou destruída pelos homens e seus esforços em criar medidas apotropaicas para impedir a natureza de se manifestar.

Carmilla, dessa forma, tenta expor o poder que existe em tudo que é selvagem e que vem da natureza. Em um diálogo com o pai de Laura sobre a praga que assola a região onde eles estão, tal característica pode ser observada novamente. Enquanto a figura masculina da narrativa prega sobre como Deus irá salvá-los do que quer que esteja acontecendo, Carmilla questiona o poder do Deus cristão e indica que o que está acontecendo é algo mais primitivo e forte, é algo que não pode ser controlado:

Criador! Natureza! - disse a jovem, respondendo ao meu amável pai. - E esta praga que assola a região é natural. Natureza. Tudo vem da Natureza... não é? Tudo o que existe no céu, na terra e embaixo da terra opera e vive segundo os comandos da Natureza? Creio que sim. (LE FANU, 2010, p.76grifos meus)

A forma felina assumida por Carmilla durante a narrativa, por sua vez, também tem a ver com essa natureza e com a força do selvagem e do primitivo que foge ao controle da sociedade Vitoriana. Como Maria Esther Maciel observa em um estudo sobre 
animalidade, "a parte animal, uma vez manifesta, despojaria o homem de sua humanidade, conduzindo-o ao grau-zero de sua própria natureza" (2016, p.17), e Carmilla precisa ser desumanizada para poder ser destruída. Todos os desejos reprimidos e o que não é aceito são personificados na personagem que assume a forma de um grande felino antes de contaminar suas vítimas. A transformação da personagem em um animal, além de desumanizar Carmilla, ainda contribui para ligá-la ao seu lado ctônico, tendo em vista que o relacionamento entre homem e animal está diretamente conectado à ideia de poderes malignos, subterrâneos e tudo que possa ser repreensível. E nada é mais repreensível que a homossexualidade que vem de fora para cooptar a filha do inglês e tirar o poder dos homens da comunidade.

Como Marcia Heloisa Amarante Gonçalves observa em sua dissertação sobre animalidade em Drácula, com as teorias de Darwin de seleção natural e de que todos os seres tem uma forma ancestral em comum, surge a ideia da existência de um parentesco diabólico, e na literatura vitoriana, "o animal-homem desponta como deformidade e é preciso reconhecê-lo, classificá-lo, segregálo o quanto antes" (2012, p.84-85). Após a confirmação da culpa de Carmilla, que vem com sua imagem em um quadro no qual se lê o nome de "Mircalla, Condessa de Karnstein", e no relato do Coronel Spielsdorf - que a reconhece como Millarca (outro anagrama), assassina de sua sobrinha -, a figura demoníaca é então reconhecida como vampira, classificada como uma Karnstein e, finalmente, mutilada, a fim de expulsar o mal da comunidade.

Ao desafiar a racionalidade do período com sua monstruosidade, Carmilla desautoriza a sociedade Vitoriana, que precisa tentar 
controlá-la e explicá-la racionalmente através da ciência, para enfim, destruí-la através da religião. A ofensa que ela oferece é grande demais, pois ela não se contenta com as garotas camponesas da região - das quais em nenhum momento alguém parte em defesa -, ela se alimenta de duas garotas da alta classe. Seu relacionamento com Laura é perigoso, uma vez que desautoriza o pai e traz o erotismo homossexual para dentro da casa dos ingleses, contaminando a pureza da filha e ameaçando o protótipo do "anjo do lar"11 - que Virginia Woolf vai dizer habitar todos os lares Vitorianos naquela época. Carmilla viola o corpo de sua vítima com mordidas e, como Gonçalves ainda observa:

O corpo invadido pelo animal - por violação o ou anomalia orgânica - é também um corpo erotizado, que representa a ansiedade vitoriana com a definição de papéis sexuais, a sombra da homossexualidade, os embrionários movimentos feministas e o temor inspirado pela miscigenação. (2012, p.86)

Nesse sentido, o contágio que Laura sofre é repleto de boa parte dos medos Vitorianos. Se com o gradual predomínio da ideologia patriarcal em detrimento de culturas matriarcais, o mito do vampiro passou a ser mais associado à transgressões das normas sociais, "fundamentadas em um pensamento cristão e, por conseguinte, masculino" (SILVA, 2010, p.24), é interessante notar que o vampiro assumiu o papel das bruxas depois do século XVIII:

110 anjo do lar é descrito por Woolf como "extremamente simpática. Imensamente encantadora. Totalmente altruísta. Excelente nas difíceis artes do convívio familiar. Sacrificava-se todos os dias. (...) em suma, seu feitio era nunca ter opinião ou vontade própria, e preferia sempre concordar com as opiniões e vontades dos outros. E acima de tudo, nem preciso dizer - ela era pura. Sua pureza era tida como sua maior beleza enrubescer era seu grande encanto. Naqueles dias - os últimos da rainha Vitórica - toda casa tinha seu Anjo." (2010, p.12) 
Há provas de que o declínio dos julgamentos de bruxaria, impostos de cima pela legislação iluminista da imperatriz M. Teresa, seguiu-se um aumento na crença de vampiros e vampirismo. Os vampiros ofereceram uma explicação sobrenatural alternativa para os infortúnios quando a bruxaria já não se encontrava mais disponível. (BAILEY, 2003, p.136)

A vampira lésbica que contamina a família nobre e católica, transgredindo as normas sociais e colocando a filha do inglês em perigo, assume um papel, de fato, semelhante ao das bruxas que eram condenadas e queimadas. Carmilla tem sua sepultura violada pelos homens respeitáveis da comunidade, seu corpo avaliado e exumado, uma estaca pontiaguda cravada em seu coração, é decepada e, finalmente, tem seu corpo reduzido a cinzas ${ }^{12}$. A narrativa imposta pela igreja católica em momentos como o da caça às bruxas, na qual as mulheres eram demonizadas e associadas a uma natureza monstruosa, em certa medida, se assemelha bastante com a da vampira.

Essa demonização das mulheres, que não é exclusiva de um período histórico específico, como bem apontado por Silvia Federici, mas parece perseguir as mulheres incansavelmente através dos séculos, foi intensificada com o estabelecimento do capitalismo. Em um estudo que aborda a caça às bruxas como havendo sido um movimento que tentava destruir o controle que as mulheres haviam adquirido sobre sua própria função reprodutiva, Federici nota que

12 "A sepultura da Condessa Mircalla foi aberta; o general e meu pai reconheceram, na face agora exposta, a bela e pérfida hóspede. (...) Os dois médicos, um ali presente, o outro representado pela pessoa do promotor público, atestaram fatos absolutamente fabulosos (...) Então, segundo a antiga prática, o corpo foi exumado e uma estaca pontiaguda foi cravada no coração da vampira (...) Em seguida, a cabeça foi decepada (...) O corpo e a cabeça foram, posteriormente, depositados sobre uma pilha de lenha e reduzidos às cinzas". (LE FANU, 2010, p.140-141) 
o capitalismo precisou destruir "a herege, a curandeira, a esposa desobediente, a mulher que ousa viver só, a mulher obeah que envenenava a comida do senhor e incitava os escravos a rebelião" (2017, p.24 - Grifo da autora) como forma de controle.

O medo que as mulheres da comunidade de Carmilla parecem proporcionar, ao se regularem sozinhas sem a figura de um mestre, tem muito a ver com a repressão que o patriarcado tentou estabelecer em relação aos corpos das mulheres. A personagem identificada como mãe da vampira, durante o baile no qual encontra o general Spielsdorf, tenta (e consegue), mais de uma vez, se desvencilhar do general que insiste para que ela remova sua máscara, em uma espécie de flerte. Com sua desobediência, ela mostra que não pode ser desestabilizada pelo homem em questão. Carmilla, por sua vez, além de seduzir, violar o corpo de Laura e estabelecer com a mesma uma relação durante a narrativa, também retira o poder do pai, que é excluído da história das duas. Assim, as vampiras de Le Fanu não inspiram apenas o medo do contágio com o estrangeiro e o medo do contágio sexual e homossexual, mas realizam uma transgressão que exclui o patriarcado, colocando-o em segundo plano. O medo de perder o lugar frente à forças femininas é um dos mais presentes na narrativa, da mesma maneira que foi na caça às bruxas e mesmo anteriormente, na perseguição dos hereges, que condenou e matou um número enorme de mulheres, muito mais do que em qualquer outro momento histórico anterior. Para Federici:

Desde tempos muito antigos (depois que o cristianismo se tornou a religião estatal no século IV), o clero reconheceu o poder que o desejo sexual conferia às mulheres sobre os homens $e$ tentou persistentemente exorcizá-lo, identificando 
o sagrado com a prática de evitar as mulheres e o sexo. Expulsar as mulheres de qualquer momento da liturgia e do ministério dos sacramentos; tentar roubar os poderes mágicos das mulheres de dar vida ao adotar trajes femininos; e fazer da sexualidade um objeto de vergonha - esses foram os meios pelos quais uma casta patriarcal tentou quebrar o poder das mulheres e de sua atração erótica. $(2017$, p.80)

Embora as tentativas de controlar os corpos das mulheres, como Federici nota, venham junto com o cristianismo, as narrativas que seguiram com o desenvolvimento do capitalismo silenciaram cada vez mais a sexualidade feminina, primeiro chamando-as de bruxas, para depois demonizá-las como vampiras ou qualquer outro monstro que viesse suprir a necessidade de cada época específica. O medo do desejo sexual das mulheres e, mais, o receio delas não precisarem dos homens, assusta. Por isso, quando as mulheres conseguem estabelecer um grupo fechado, no qual os homens não conseguem penetrar, a ordem Vitoriana é ameaçada em Le Fanu. O medo do feminino e de tudo aquilo que possa ser relacionado a ele, desde os ciclos menstruais - que, por sua vez, são ligados às fases lunares - até a maternidade, acabam expondo, em Carmilla, boa parte das ansiedades Vitorianas.

A vampira de Karnstein, em última análise, ameaça o patriarcado. Como Barbara Creed vai notar, "como com todos os estereótipos do feminino [o monstro feminino] é definido em relação a sua sexualidade"13 $(1993$, p.3), e Carmilla assume essa natureza demoníaca por seu poder sexual - e homossexual -,

13 "as with all other stereotypes of the feminine [the female monster] is defined in terms of her sexuality". (Tradução minha) 
mostrando sua soberania ao não depender de figuras masculinas nem ser dominada por elas.

Assim, enquanto a narrativa recupera a natureza ctônica de Coleridge para construir a vampira protagonista - em uma constante luta de poderes entre natureza e ciência -, ela desafia a ordem apolínea da sociedade, invocando o horror Vitoriano da perda de autonomia masculina para algo que não pode nem mesmo ser explicado racionalmente, algo que é identificado na novela como tendo uma origem mais primitiva, selvagem e, também, feminina. Carmilla: a vampira de Karnstein subverte o papel social da mulher na literatura Vitoriana com sua homossexualidade, com o ataque à maternidade e com a ameaça às próximas gerações. No entanto, a destruição de Carmilla pelos homens da narrativa, com toda uma violência contra seu corpo, marca a impossibilidade de completar o ato de transgressão, bem como a necessidade Vitoriana de punir tal tentativa de subversão de papel. A presença de uma vampira lésbica que ataca diretamente o patriarcado e o poder masculino não poderia ter outro fim. Talvez nem nos dias de hoje.

\section{REFERÊNCIAS}

AUERBACH, Nina (1995). Our Vampires, Ourselves. Chicago: University of Chicago Press.

BAILEY, Michael D (2003). Historical Dictionary of Witchcraft. Lanham, Maryland, and Oxford: The Scarecrow Press.

COLERIDGE, Samuel Taylor (2009). "Christabel". In: COLERIDGE, Samuel Taylor. The Major Works. Oxford: Oxford University Press.

CREED, Barbara (1993). The Monstrous Feminine: Film, Feminism, Psychoanalysis. USA: Routledge. 
FARRAR, Janet e Stewart (2012). The Witches' Goddess: The Feminine Principle of Divinity. USA: David \& Charles Edição Kindle.

FEDERICI, Silvia (2017). Calibã e a bruxa: mulheres, corpo e acumulação primitiva. São Paulo: Elefante.

GONÇALVES, Marcia Heloisa Amarante (2012). Animalidade confundida: vilania e monstruosidade em Drácula. (Dissertação). Universidade Federal Fluminense, Niterói.

LECOUTEUX, Claude (2003). História dos vampiros: autópsia de um mito. São Paulo: Unesp.

LE FANU, Sheridan (2010). Carmilla: a vampira de Karnstein. São Paulo: Hedra.

MACIEL, Maria Esther (2016). Literatura e animalidade. São Paulo: Civilização Brasileira.

PAGLIA, Camille (1991). Sexual Personae: Art and Decadence from Nefertiti to Emily Dickinson. New York: Vitage Books.

SILVA, Alexandre Meireles da (2010). "Introdução". In: LE FANU, Sheridan. Carmilla: a vampira de Karnstein. São Paulo: Hedra.

WOOLF, Virginia (2012). Profissão para mulheres e outros artigos feministas. Porto Alegre: L\&PM Pocket. 


\section{VAMPIRAS DO SERTÃO NO CONTO "AS MORFÉTICAS", DE BERNARDO ÉLIS}

Fabianna Simão Bellizzi Carneiro (UFG)

Recebido em 01 jan 2019. Fabianna Simão Bellizzi Carneiro é Doutora em Aprovado em 10 jun 2019. Estudos Literários pelo Programa de Pós-Graduação em Letras da Universidade do Estado do Rio de Janeiro. É Professora Adjunta da Unidade Acadêmica Especial de Letras e Linguística, Universidade Federal de Goiás, Regional Catalão, onde também atua como professora permanente do Programa de Mestrado em Estudos da Linguagem. Integra o grupo de pesquisa Estudos do Gótico (CNPq). Tem experiência na área de Letras, com ênfase em Estudos Literários, Literatura Comparada e Literatura Fantástica, atuando principalmente nos seguintes temas: Literatura e alteridade, Identidade e Cultura e pensamento social e político brasileiro. Lattes: http://lattes.cnpq.br/2169923665930283. E-mail: carneirofabianna@gmail.com

Resumo: O presente artigo levanta reflexões a respeito do mito do vampiro e como este pode ser relido em diferentes sociedades, especificamente na sociedade sertanista goiana das primeiras décadas do século $X X$, que sofria os impactos da industrialização no campo. Objeto de complexas interpretações sobre o Brasil, o sertão evoca profícuas discussões sobre a formação da sociedade brasileira, alinhavadas com o excludente discurso que o nomeia como local oposto à modernidade e ao progresso da cidade. No caso deste trabalho, objetivamos traçar paralelos entre o mito do vampiro 
europeu e a presença de elementos caracterizadores desta personagem no conto "As morféticas", publicado inicialmente em 1944 na coletânea Ermos e Gerais, do escritor goiano Bernardo Élis (1915-1997), para que assim possamos comprovar a hipótese de que os monstros que rechaçamos e segregamos podem, sim, falar a respeito de questões econômicas e políticas.

Palavras-chave: Mito do vampiro; Alteridade; Sertão Goiano; Literatura Regionalista; Literatura Brasileira.

Abstract: The present article raises reflections concerning the vampire's myth and how it can be reread in different societies, especially in the hinterland's society from Goiás in the first decades of the $20^{\text {th }}$ century, which suffered impacts from the countryside's industrialization. Object of complex interpretation about Brazil, the hinterland evokes fruitful discussions about the Brazilian society formation lined with excluding discourse that names itself as the local opposed to modernity and the progress of the city. As for this work, we aim to outline parallels between the myth of the European vampire and the presence of the character's typified elements in the tale "As morféticas", published initially in 1944 within the collection Ermos e Gerais, by the writer from Goiás, Bernardo Élis (1915-1997), so we can prove the hypothesis that the monsters we reject and separate may, actually, discuss about economic and political matters.

Keywords: Vampire myth; Alterity; Goiás Hinterland; Regionalist Literature; Brazilian Literature.

\section{POST MORTEM E O MITO DO VAMPIRO: BREVES CONSIDERAÇÕES}

"Uma força me expulsa do túmulo Para procurar de novo os bens de que estou privado, Para amar de novo o esposo já perdido E para aspirar o sangue de seu coração". Goethe, A noiva de Corinto (1797) 
Podemos considerar que as lendas que sustentam a presença da figura sugadora de sangue são autóctones. Muito embora em algumas regiões notemos elementos e características que se aproximam, de uma forma geral cada região possui vetores próprios e específicos que delineiam a figura do vampiro. Há registros de uma figura endemoniada que bebia sangue no ano de 600 a.C. na China; assim como no Leste Europeu e até mesmo no Peru précolombiano, em que relatos de moradores explicavam a presença dos "canchus", que bebiam sangue dos jovens adormecidos para assim conseguirem a energia do Sol (COSTA, 2009).

Salienta-se que durante a Idade Média o arquétipo da figura maléfica e sugadora serviu aos preceitos religiosos e puritanos do momento, ou seja, pessoas dadas às crenças ou comportamentos vampíricos seriam queimadas na fogueira. A literatura europeia conseguiu captar esse espírito medievo e inseri-lo nos ideais estéticos do momento, daí que o século XIX nos ofereceu obras de grande alcance popular como os romances Frankenstein (1816) e Drácula (1897) e o conto "Carmilla" (1872), advindos da literatura de horror e do romance gótico (COSTA, 2009).

Comumente desenhado como um ser de tez pálida, caninos longos e pontudos, unhas grandes, que suga sangue à noite de quem está dormindo, teme a luz do dia assim como teme alho e crucifixos e que pode se metamorfosear em animais como ratos e morcegos, o vampiro reúne temas eloquentes, como morte, sexualidade, religiosidade e política: "[...] desde 1741, o termo vampiro assume na Inglaterra o sentido de tirano que suga a vida de seu povo (LECOUTEUX, 2005, p.12)". Até mesmo textos eruditos, como o do monge beneditino de Semones, Augustim Calmete (Apud LECOUTEUX, 2005) já se debruçaram sobre o 
tema do vampirismo, ao explicá-lo como consequência da subnutrição dos povos balcânicos. Esses constructos não apenas alimentaram o imaginário de várias sociedades, mas trouxeram-nos informações que, ancorando-se no real, acabam por trazer importantes elementos psíquicos de nossos antepassados, afinal

o vampiro faz parte da história desconhecida da humanidade, desempenha um papel e tem uma função; não brotou do nada no século XVII ou $X V I I I$. Ele se inscreve num conjunto complexo de representações da morte e da vida, que sobreviveu até nossos dias, certamente com uma riqueza bem menor do que naquele passado distante que tendemos a confundir com séculos de obscurantismo, aquelas épocas remotas e ignorantes que baniram as Luzes da razão. (LECOUTEUX, 2005, p.15)

Ainda que o século XVIII tenha imortalizado a figura do conde vampírico como um ser decadente e funesto, símbolo maior da própria decadência aristocrática, há que se destacar dois importantes aspectos que circundam a figura desse avatar: o fato de transgredir os limites da morte por circular entre zonas intersticiais; e sua eterna busca por sangue humano, afinal elucubrações a respeito da post mortem percorrem a história da humanidade, suscitando pesquisas e tratados de diversas áreas, desde estudos religiosos, filósofos, médicos, passando por crenças de cidadãos comuns, até sociedades científicas especializadas no debate do tema, e aqui podemos citar os estudos do psiquiatra norte-americano Raymond Moody, que cunhou o termo EQM - experiência de quase-morte - para se referir aos casos em que pessoas voltam de um coma profundo e relatam visões do além (DEL PRIORE, 2014). 
O fato é que, para além de respostas ou tratados conclusivos (provavelmente não os teremos), continuaremos nos debruçando sobre um tema ardiloso, por vezes passional, e muito intrigante: a passagem entre a vida e a morte, ou o limite que separa o vivo e o morto, a presença e a não presença; e a figura do vampiro, entre tantas figuras fantasmagóricas, é a que mais nos causa fascínio e aflição, principalmente por transgredir a ordem, por romper, por fissurar e contradizer a certeza única de todo ser vivo: a morte.

Cabe sublinhar que determinados grupos procedem de forma diferente quanto aos cortejos dos ritos funerários. Alvaro Chrispino (1994) destaca que, de uma forma geral, podemos observar três momentos nos rituais funerais que se repetem ao redor do mundo: encontro do indivíduo com a morte do outro; transporte do morto para seu novo mundo; lembrança objetiva do morto através do cadáver.

Oriundos de priscas eras, tais ritos reforçam a certeza da passagem para "outro mundo", além de impedirem o morto de "morrer novamente" cada dia - fato considerado possível por vários povos, daí muitos acreditarem que os que não tiveram funeral apropriado são destinados a uma existência lamentável e impedidos de entrarem no mundo dos mortos: "São os mortos mais perigosos, porque desejariam reagregar-se ao mundo dos vivos, mas não podendo fazê-lo, conduzem-se como estrangeiros hostis" (VAN GENNEP, 2011, p.138). Também se acreditava que aqueles que tiveram uma "morte má" iriam compor as hordas de desagregados ao mundo dos mortos, como os suicidas; pessoas que tiveram uma vida desajustada (de acordo com determinados preceitos para algumas sociedades); os que tinham um eventual traço físico ou marca de nascença; os marginais; pessoas vingativas; 
aqueles com vestes funerárias inadequadas, ou seja, não viver de acordo com certas condutas e códigos morais de uma sociedade seria um passaporte para a "morte má".

Vê-se, então, que o mito do vampiro nos leva a uma reflexão sobre polos essenciais de nossa existência, como vida, morte, amor, compaixão, cuidado com o outro. Porém, de todos os cotejamentos a respeito do mito do vampiro, o mais peremptório e sobressalente refere-se à temática da alteridade, ou seja, a existência do vampiro reforça a condição de alguém que durante sua vida não seguiu determinados parâmetros impostos pela sociedade. Sob essa perspectiva, o mito do vampiro "[...] retoma por sua conta as noções de morte boa e má, a de transpasse como recompensa de uma vida de retidão e de justiça, a de castigo póstumo" (LECOUTEUX, 2005, p.177).

Importante mencionar que o mito do vampiro, tal como conhecemos, ganha contornos reforçados durante o período medieval, época em que os valores cristãos de retidão e boa conduta predominavam no continente europeu, daí que pessoas que fossem contra as veleidades cristãs, como seguidores de outras seitas, feiticeiros, judeus, mulheres, pessoas não batizadas, e todos os que estavam predestinados à uma vida post mortem aviltante, ou seja, as alteridades, seriam categorizados como fantasmas ruins: os vampiros.

Resultado de uma visão de mundo balizada pelos princípios cristãos, o mito do vampiro põe em causa o dualismo corpo/alma e forja outras ambiguidades que decantam algumas incertezas: mortal ou imortal? Vítima ou carrasco? Culpado ou castigado? Não teremos respostas, embora alguns artistas e cineastas tenham visto no mito do vampiro uma espécie de narrativa filosófica e uma 
longa meditação sobre as noções de vida e morte, e no papel de Nosferatu, "[...] Klaus Kinski deu a entender recentemente que a imortalidade é um fardo pesado" (LECOUTEUX, 2005, p.176).

Tais questionamentos descortinam e colocam em relevo importantes ocorrências do mito do vampiro em outras narrativas que não as europeias, bem como a forma com que essas manifestações se comunicam com a realidade de determinadas comunidades, e aqui podemos citar o caso brasileiro, afinal, ao chegarem a solo americano, os europeus colonizadores trouxeram um arcabouço de informações, lendas, mitos, crenças, que, ao se implantarem em nossas sociedades, amalgamaram-se às crenças por aqui já estabelecidas. No caso específico deste trabalho, sublinharemos como o mito do vampiro comunica-se com o conto "As morféticas".

\section{DE LILITH ÀS “VAMPIRAS” DO SERTÃO: A MARCA DA ALTERIDADE}

Dentre o elenco de personagens marcantes, entidades ou deusas mitológicas que falam da condição feminina ao longo da história dos povos, possivelmente a figura de Lilith tenha sido a mais emblemática. De origens longínquas que se situam na velha Babilônia, o mito de Lilith liga-se aos grandes mitos da criação: inscrições descobertas nas ruínas da Babilônia relacionam o mito aos ritos sagrados de fecundidade. A etimologia nos permite antever uma filiação entre Lilith e as palavras sumérias "lulti" (lascívia) e "lulu" (libertinagem) (BRUNNEL, 2005, p.582-583), o que pode explicar a sedução e sensualidade utilizadas por essa figura como força destrutiva: "Foi provavelmente durante o cativeiro da Babilônia que os judeus travaram conhecimento com esse demônio, 
ativo principalmente à noite (BRUNNEL, 2005, p.582)". Com forte presença em testemunhos da tradição oral jeovística, Lilith é mencionada no fim do Edom como uma figura ligada ao deserto apocalíptico, o que pode ter contribuído para a construção de sua figura como espécie de demônio feminino ou arquétipo da mulher sedutora e enganadora. A tradição judaica inspiraria a criação do mito tal como o conhecemos: paixão da noite, anjo assassino das parturientes, devoradora de recém-nascidos, sedutora dos adormecidos, Lilith surge como a primeira mulher de Adão em pé de igualdade com seu par: criada do pó e insuflada com o sopro divino. Entretanto, ao requerer para si satisfação sexual e prazer, Lilith é retificada mitologicamente por meio da debilidade de Eva (ROBLES, 2006, p.33-36). De forma a se vingar de Adão, Lilith suga o sangue e estrangula todos os descendentes de seu ex-marido enquanto ainda crianças.

Descrita por uns como ser alado com longos cabelos semelhante à representação de um anjo; e por outros como uma mulher de caninos ferozes que se casa com o demônio Sama'el; Lilith, a Rainha do Mundo Inferior, é evocada em culturas que reconhece na figura feminina uma potência sexual de alta periculosidade, sobretudo para certas comunidades poderem estabelecer "[...] um patriarcado que, para se legitimar, tinha de desqualificar a autoridade feminina, considerando-a, no mínimo, a perturbadora do leito conjugal (ROBLES, 2006, p.34)". Importante avultar que o mito de Lilith tangencia um conjunto de superstições e construções maléficas em torno da figura feminina com tamanha crueza e voracidade, que a ideia de maldade, sedução e persuasão femininas advindas do mito de Lilith perdura até a contemporaneidade: 
A imagem do demônio noturno que desliza para o leito daquele que dorme incauto é, entretanto, a preferida das religiões modernas. 0 exemplo de uma instigadora inclinada para o mal é o que melhor expressa os preconceitos que predominaram em relação à função perturbadora das mulheres, eternas responsáveis pelo pecado original que levou os homens a perderem a sua pureza, a se envergonharem do próprio corpo e a atentar contra os ditames divinos ao aspirarem à imortalidade. (ROBLES, 2006, p.35)

Não apenas as religiões, mas podemos aferir que as artes também se inspiraram nessa figura da mulher maléfica, sedutora e de caninos ferozes. As mulheres vampiro, não com rara frequência, se apresentam com fria crueldade e se deleitam com a lenta agonia de suas vítimas. Essas perturbações se instalam nas narrativas literárias como uma constante, conforme podemos notar no excerto abaixo retirado da obra Entrevista com vampiro:

Atrás dela várias caveiras pintadas moveram-se subitamente contra o negrume, vultos vestidos de preto que carregavam máscaras, deixando aparecer apenas mãos brancas que seguravam a ponta de uma capa ou as pregas de uma saia. Ali havia mulheres-vampiro, misturando-se a homens na direção da vítima. Agora todos eles, um a um, jogaram fora as máscaras que se amontoaram numa engenhosa pilha, os bastões qual ossos, as caveiras sorrindo para a escuridão do teto. E ali estavam sete vampiros, três dos quais mulheres, seus seios brancos reluzindo nos corpetes pretos e justos das vestes, suas faces luminosas, seus olhos escuros sob cachos de cabelo preto. Absolutamente lindas, parecendo deslizar juntas para aquela figura humana rosada, ainda que pálidas e frias 
em comparação com os cabelos absolutamente dourados, aquela pele rosa. (RICE, 1976, p.193-194)

Notamos, também, que o trecho da obra de Rice (1976) guarda paralelos com uma passagem do conto "As morféticas", que em linhas gerais traz a história de um caixeiro-viajante egresso de Anápolis em direção a Mato Grosso. Durante o percurso, o rapaz precisa enfrentar uma parada de emergência por conta de avarias no caminhão em que ele pegara carona. Ao invadir um rancho, supostamente abandonado, o viajante resolve descansar em uma rede. Em um misto de sonho e realidade, o rapaz imagina que o rancho fosse habitado por uma linda proprietária que assim o acordaria:

Mas a virgem viria linda. Entraria. Começaria a despir-se e sua carne cheirava e iluminava como uma brasa meu sensualismo. Ela ainda não me havia visto e agora que me percebeu queria ocultar a vergonha, as suas formas pudicas, fugindo para dentro do quarto.

Agarro-a freneticamente. Ela treme, tem no rosto o medo delicioso das crianças. Numa reviravolta, entretanto, muito natural em sonhos (eu já caíra numa sonolência boa), começa a abraçarme levemente, - vai beijar-me. E, de súbito, transforma-se numa fera terrível - morde-me. (ÉLIS, 2005, p.245)

Separadas no tempo e trazendo perspectivas completamente díspares - a escritora estadudinense Anne Rice publica sua obra em 1976, ancorada em temas filosóficos como existencialismo, crise de identidade, medo e morte; ao passo que a tônica do conto de Bernardo Élis, "As morféticas", aborda as precárias condições das mulheres abandonadas. Entretanto, as duas narrativas convergem 
em um ponto: tanto a "mulher-vampira" de Rice quanto a "mulhermorfética" de Élis nos fazem lembrar que a figura do monstro pode dramatizar aquilo que nossas sociedades reprimem e oprimem, como a sexualidade feminina, o proletariado, outras culturas e outros grupos étnicos, ideologias alternativas, homossexualidade e bissexualidade, conforme observa Franco Moretti (Apud DONALD, 2000). Em ambas as narrativas, o monstro serve como veículo encontrado pelos autores para trazer à lume a questão da alteridade; de se dar voz aos grupos minoritários e que não se posicionam como sujeitos de suas próprias histórias; bem como falam dos monstros que as sociedades segregam e rechaçam.

No caso específico do conto "As morféticas", há que se traçar um estudo da palavra "sertão" de forma a entendermos como se construiu no imaginário brasileiro essa ideia do espaço sertanista enquanto abrigo das alteridades.

Muitas vezes estruturado como espaço das longas distâncias, do desconhecido, do inacabado, do atrasado ou do rústico, o sertão do Brasil é visto em contraste com o litoral em seus aspectos culturais e sociais. Objeto de complexas interpretações sobre o Brasil, o sertão pode evocar profícuas discussões sobre a formação da sociedade brasileira, alinhavadas com o excludente discurso que o nomeia como local oposto à modernidade e ao progresso da cidade.

Fomos colonizados, majoritariamente, por um país que tinha os olhos voltados para o mar, daí que antes de se opor à ideia de região colonial, o sertão se opunha ao litoral brasileiro. A própria lexicologia da palavra carrega consigo a antiga relação entre colonizador e colonizado, adquirida a partir de um tipo de linguagem que 
desconsiderava a fala do outro que estava sendo colonizado. Plasmase, portanto, à palavra sertão a ideia de desalinho, de dissonância:

De-Sertum, supino de desere, significa "o que sai da fileira", e passou à linguagem militar para indicar o que deserta, o que sai da ordem, o que desaparece. Daí o substantivo desertanum para indicar o lugar desconhecido onde ia o desertor, facilitando a oposição lugar certo e lugar incerto, desconhecido e, figuradamente, impenetrável. [...] o adjetivo certum através da expressão domicilium certum e da forma que tomou em português arcaico, certão, pode haver contagiado a significação (não a forma) de desertanum como "lugar incerto", sertão, vocábulo que aponta sempre para um sítio oposto e distante de quem está falando. (TELES, Apud VICENTINI, 1998, p.45 - grifos da autora)

O referencial, à época, era concebido a partir do ponto de vista da supremacia europeia, que avistava, de suas naus, o litoral como sendo "o outro lugar" ou "o lugar do outro". Construiu-se no Brasil, desde tempos coloniais, a ideia de sertão como lócus do distante em comparação ao litoral e, também, como espaço em total desalinho com a região colonial. Ainda mais significativa é a intenção de se naturalizar a palavra como algo que nos leva à noção de despovoamento, abandono ou o território do vazio a ser preenchido pelo colonizador, por isso, o mundo da desordem. Passado o período inicial de colonização, quando os bandeirantes iniciam o processo de exploração rumo ao interior, a visão que os colonizadores tinham com relação ao continente brasileiro se dissemina para o interior, lugar dominado pela natureza e que não poderia se juntar ao espaço da civilização litorânea que se formava. 
Essa ideia de sertão como espaço em desalinho, criada e mantida por intelectuais brasileiros durante várias décadas, alimentou o imaginário nacional de tal forma, que ainda perdura um tipo de discurso sobre o sertão enquanto comunidade em que se marca uma diferença. Usamos comparações e diferenciações para dizermos o que é o sertão ou o que não é. Para além de questões geográficas, nomeamos as diferenças e tentamos impô-las como classificação do espaço sertanejo: "Trata-se aqui de apontar os efeitos performativos da atividade de inúmeros intelectuais que escrevem sobre paisagens sociais e físicas ditas sertanejas" (SOUSA, 2010, p.108).

Podemos aferir que esses efeitos performativos, destacados por Souza (2010), iniciam-se através de vetores geográficos e espraiam-se para outras instâncias. Ao atingirem a instância social, percebemos um pernicioso movimento que confere às comunidades ali instaladas certos constructos, a saber: sociedades atrasadas, inferiores, não-civilizadas, caipiras, que além de reforçarem o estigma de atraso, fortalecem a inferioridade da população do sertão. No que tange à instância econômica, percebemos um discurso ainda mais truculento, uma vez que a elite econômica atribuía aos moradores do sertão a causa do atraso econômico, ao passo que esses eram vítimas do processo capitalista que já grassava no interior e que alijava os menos favorecidos.

Devemos relembrar que no período posterior à Primeira República (1889-1930), as aspirações da elite brasileira encetavam todo o afã de modernizar o país. Inaugurávamos o período do Estado Getulista (1930-1945) e estávamos em acelerado processo de industrialização. Porém, as parcelas mais miseráveis da população iam, aos poucos, sendo esquecidas e marginalizadas, compondo os 
quadros de exército de reserva próprios dos sistemas capitalistas. Tal se reflete de forma cáustica em várias narrativas de Bernardo Élis, em que as personagens

são sempre os párias, indigentes, loucos, agregados miseráveis, enfim, toda uma galeria de personagens neonaturalistas, teratológicas, com suas taras e problemas, numa visão macabra e terrível do mundo, como se não houvesse, nunca, para o homem pobre a esperança e a beleza da felicidade material, porquanto a outra felicidade, aquela que mais se identifica com a Natureza do espírito, esta parece completamente alheia à obra de Bernardo Élis. (TELES, 2007, p.70)

Necessário mencionar que nas capitais brasileiras, a terceira década do Século XX viu eclodir uma gama de movimentos populares, greves, provocação de animosidade nas classes operárias e todo um conjunto de ações que denunciava problemas de classes não resolvidos pelos governantes. No campo, especificamente, a questão ganha contornos mais exacerbados. Em Goiás, o ano de 1930 foi decisivo para incluir o Estado no crescente sistema capitalista, o que não significou superação do atraso goiano. A agricultura e pecuária, principais itens da economia de Goiás, ganharam investimentos e um sistema mecanizado. Entretanto, os trabalhadores rurais continuavam em estado de penúria e desolação, esquecidos e enganados pelos grandes proprietários de terras. No interior do Estado, pretendia-se uma ascensão aos moldes das regiões industrializadas do Brasil, por meio do desenvolvimento da economia, da política, da sociedade e da cultura regionais (CHAUL, 2010, p.170). Foi a época em que, inclusive, as dicotomias atraso/ progresso, velho/novo, moderno/tradicional, tornaram-se o centro 
das discussões da elite rural. O advento da sociedade capitalista, nas cidades brasileiras, fez com que o moderno alicerçasse a ideia de progresso construída há alguns séculos na Europa. A oligarquia rural brasileira acata essa ideia. Existia uma proposta deliberada de erradicar do campo as marcas do atraso e do velho. Bernardo Élis propunha um projeto ideológico muito atuante "no campo da reivindicação social, isto é, sacode uma tradição medieval, preparando novas eras: a da prevalência dos direitos humanos nesse 'chão analfabeto' que era o seu Goiás" (OLIVAO, 1975, s/p, grifos da autora). Se o desejo da elite era o de hostilizar a pobreza e abandonar os miseráveis do campo à sua própria sorte, Élis expunha essas mazelas de forma crítica e tensa, projetando o homem do sertão em sua angústia, amargura e incertezas.

Cabe salientar que, dentre esse grupo de pessoas apartadas e rechaçadas, as mulheres seguiam na linha de frente, ou seja, sentiam de forma mais pungente as consequências econômicas. No início do Século XX, começa a haver um êxodo rural em direção às cidades, principalmente São Paulo. As contradições e tensões criadas no campo, por conta do processo capitalista, fizeram com que, em muitos casos, os homens saíssem à procura de emprego, deixando mulheres e filhos abandonados, afinal, na sociedade sertanista do período, as mulheres se subordinavam por completo aos homens. Ao abandono somava-se a precariedade de vida, doenças, fome, além de um cabedal de problemas que grassava no campo brasileiro, mobilizando artistas e escritores de forma que não ficassem indiferentes a esse status quo. A realidade que Bernardo Élis apresenta na coletânea Ermos e Gerais é a realidade do Brasil que se esconde nos ermos e que mantém as peias do passado miserável. Representantes da 
corrente regionalista, durante o Modernismo, e, especificamente, Élis, apresentam uma forte crítica social contra os que subjugavam e humilhavam vítimas da pobreza e miséria no sertão brasileiro. Em Ermos e Gerais, o abandono das personagens representa a desumanização do homem aniquilado de forma exagerada, que beira o animalizado e monstruoso, irrompendo o não convencional de forma a intensificar o significado da miséria humana. No conto "As morféticas" percebemos a precariedade e o abandono destinados às mulheres a começar pela descrição do espaço: inóspito, afastado da civilização, cheio de percalços e perigos:

Umas nuvens muito grandes começaram a formarse no meio do céu. Um bando de urubus brincava de roda-da-flor, na rua vastíssima do infinito, subindo, até sumir-se atrás das nuvens, como se se escondesse atrás de algum móvel, de uma moita. Depois, um se desprendeu daquela altura encapetada, e com as asas feito duas foices, veio descendo numa velocidade enorme. Atrás dele vinha outro, em perseguição. As asas dos brutos chegavam a assobiar roucamente...

Foi quando eu, que estava deitado no chão com a barriga pra [sic] cima, dei aquele tranco: uma cascavel tiniu seu chocalho com uma raiva selvagem, que abalou o bochorno. E o guizalhar áspero de sua raiva ficou empestando a calmaria, dando uma gastura enjoada na gente. (ÉLIS, 2005, p.242)

Importante relembrar que nas narrativas inglesas oitocentistas, que traziam personagens monstruosas como os vampiros, delegavam a estas figuras espaços distantes, ermos, dominados pela natureza selvagem e desafiadora e envoltos por intempéries climáticas e estradas sinuosas, conforme notamos no conto "Carmilla": 
Nenhum lugar poderia ser mais pitoresco ou solitário. O castelo fica numa pequena elevação dentro de uma floresta. A estrada, estreita e muito antiga, passa diante da ponte levadiça - que jamais vi levantada, em toda minha vida [...]. A floresta se abre numa clareira irregular e muito pitoresca diante do portão e, à sua direita, uma antiga ponte gótica, como um arco de pedra, transporta a estrada por sobre um rio que se perde em curvas através das densas sombras da floresta. (LE FANU, 2009, p.71)

A despeito do clima de suspense obtido a partir do manuseio de elementos espaciais tão categóricos e amedrontadores, há que se destacar o fato de que os monstros, representantes das "outridades" que se queria atacar, deveriam ocupar o local determinado aos que não seguissem certas condutas sociais pré-estabelecidas, e aqui retomamos a figura do vampiro. Frequentemente associado à beleza e à promessa de prazer, ele é a personificação de nossas possíveis sublimações da morte física, burlando a natureza mortal do ser humano. Embora no conto "As morféticas" não se figure efetivamente uma personagem "vampiresca", destacamos que os elementos que compõem as personagens mulheres, nesta narrativa, nos levam a aferir que, assim como os vampiros, trata-se de figuras que deveriam ocupar lugares distantes, afinal são mulheres portadoras da hanseníase. O vampiro, enquanto símbolo da devassidão, imoralidade e perversão que em muitos casos fascina e leva suas vítimas à desgraça, metaforiza-se em "As morféticas" não através de mulheres fatais e sedutoras, mas através de quatro mulheres com "[...] faces encaroçadas, as orelhas inchadas, tumefactas, uns tocos de dedos retorcidos e engelhados, o crânio pelado e purulento" (ÉLIS, 2005, p.245-246). 
Abrimos um parêntese para assinalarmos que a história das mulheres na constituição e trajetória do trabalho rural é marcada por muitos atos de discriminação naturalizada: "Discriminação respaldada pelas visões patriarcais do projeto estatal, pelo atraso na extensão dos direitos trabalhistas e previdenciários, pela exclusão em programas de crédito, comercialização, investimentos" (FERRANTE et al, 2013, p.195), avultando-se, portanto, o antigo e arraigado discurso capitaneado pelas elites, no qual as mulheres ocupam os lugares das minorias. Tal discurso inicia-se no período colonial, "[...] quando as condutas dos/as colonizados/as e suas personalidades/almas eram julgadas como bestiais e, portanto, não gendradas, promíscuas, grotescamente sexuais e pecaminosas" (LUGONES, 2014, p.936-937), e se estende durante séculos pelo Brasil, encontrando no meio rural espaço propício para se perpetuar.

Se os vampiros europeus carregam a insígnia do ser imortal preso à vida por terem em si uma amargura e um gosto maior por sangue do que o respeito pela vida humana, as "vampiras do sertão" de Bernardo Élis ratificam o discurso cristão medieval que se instalou no Brasil-colônia e que outorgava às pessoas infectadas pelo vírus da hanseníase o pecado maior da pureza cristã, afinal a doença era considerada o sinal distintivo do desvio sexual:

Chamava-se 'lepra' a muitas doenças. Toda erupção pustulenta, a escarlatina, por exemplo, qualquer afecção cutânea passava por lepra. Ora, havia, com relação à lepra, um terror sagrado: os homens daquele tempo estavam persuadidos de que no corpo reflete-se a podridão da alma. O leproso era, só por sua aparência corporal, um pecador. Desagradara a Deus e seu pecado purgava 
através dos poros. Todos acreditavam, também, que os leprosos eram devorados pelo ardor sexual. Era preciso isolar esses bodes (DUBY, 1998, p.91 grifos do autor).

Tomadas pela "podridão da alma", as mulheres morféticas do sertão bernardiano tangenciavam esse discurso entregue aos portadores da hanseníase que os determinava como lascivos e pecadores sexuais, e que além de apartados deveriam ser exterminados com palavras que exaltassem o castigo divino, levando-nos a mais uma alegoria de como as morféticas podem retomar o mito dos vampiros. Se os vampiros de outrora eram exterminados com estacas fincadas no peito, as morféticas do sertão receberiam o imperioso discurso a favor de Deus e contra Satanás, lembrando-nos afinal que "a confissão cristã, o pecado e a divisão maniqueísta entre o bem e o mal serviam para marcar a sexualidade feminina como maligna, uma vez que as mulheres colonizadas eram figuradas em relação a Satanás [...]" (LUGONES, 2014, p.938), conforme notamos no excerto:

A mulher cuspiu-me um cuspo fedorento no rosto. Meu ímpeto foi de matá-la, mas reduzi isso para um pontapé naquela fuça: - "E se saltasse mais podridão na gente?"

- "Qual! O melhor era fugir, lavar-me, desinfetarme. Uma povoação qualquer, quanto distaria?

Nesse momento o cachorrinho pegou a latir, procurando defender a mulher caída. Latia no duro, com os olhos embraseados, balançando as orelhas pesadas.

Apontei com um gozo satânico o meu revólver e espatifei-Ihe a cabeça. Afastei-me gozando a 
vingança: - Se não fosse o latido do desgraçado eu nunca teria passado por aquele momento! (ÉLIS, 2005, p.246-247)

Ratifica-se o quão a literatura de horror, ao expor monstros, fantasmas, abjeções, vampiros, o trágico-cômico, as ossadas e esqueletos, pode dizer a respeito das nossas sociedades e dos monstros que segregamos. Asquerosos, macabros ou bárbaros, Bernardo Élis fornece a seus leitores retratos de personagens retirados da mais triste realidade brasileira. São pessoas que, infelizmente, ainda vivem nos sertões e rincões de um Brasil muito macabro e que figuram no conto "As morféticas", onde a relação entre a hanseníase e as condições socioeconômicas do campo brasileiro na primeira metade do Século XX justapõe a visão elitizada e preconceituosa que reserva aos párias, doentes, desagregados e desajustados o esquecimento, a miséria e a humilhação.

\section{CONSIDERAÇÕES FINAIS}

Considerado pela crítica como autor regional, as narrativas do escritor Bernardo Élis abarcam temas universais. Ao optar por desmascarar a alienação do homem em todos os níveis, a escrita de Élis resiste a esquemas simplistas, sempre fugindo da caricatura ou do reducionismo regionais: "A situação do homem do campo de Goiás registrada pelo escritor apenas atualiza um modelo que podemos encontrar em qualquer parte do país" (ABDALA, 1983, p.104). Nas narrativas de Bernardo Élis, o que se nota é a abjeção que o outro ou diferente, com relação a determinados padrões hegemônicos, causa em pessoas que entram em contato com a suposta alteridade. 
Embora falasse das parcelas miseráveis do sertão goiano, Bernardo Élis resgatou o sentimento primordial do ser humano: o medo e o terror, daí buscar no grotesco e no mórbido, material para sua escrita. No caso específico deste trabalho, comprovamos nossa hipótese inicial de que, escondidas e travestidas, grotescamente, sob peles purulentas e putrefatas, as mulheres "mortas-vivas" do sertão bernardiano não deixam de revelar e denunciar a desassistência das famílias do meio agrário goiano, esquecidas por conta da automação que se iniciava nos latifúndios, fazendo com que pequenos produtores rurais optassem entre submeter-se ao jugo dos fazendeiros ou compor os quadros de miséria nas cidades.

Por fim, ressaltamos mais uma vez a escrita desse autor que nunca deixou de manifestar seu interesse pelo elemento humano, tão açoitado, transgressor dos limites morais, brutalizado e animalizado por conta do progresso, que avançava de encontro aos desfavorecidos. Pelas vias do regionalismo, Élis aproxima nossa realidade da literatura, fazendo-nos pensar a respeito de nossas inserções e interações cotidianas, ao transformar o localismo em uma alegoria do homem e seu universo, afinal, conforme o próprio observa: "Minhas histórias referem-se sempre à realidade" (Élis, Apud ABDALA, 1983, p.13).

\section{REFERÊNCIAS}

ABDALA, Benjamin, Jr. (1983). Bernardo Élis. Seleção de textos, notas, estudos biográfico, histórico e crítico e exercícios. São Paulo: Abril Educação. (Coleção Literatura Comentada).

BRUNNEL, Pierre (2005). Dicionário de mitos literários. Rio de Janeiro: José Olympio.

CHAUL, Nasr Nagib Fayad (2010). Caminhos de Goiás: da construção da decadência aos limites da modernidade. Goiânia: Editora UFG. 
CHRISPINO, Álvaro (1994). Conversando sobre a morte ou epistemologia da morte. Uma pesquisa sobre a morte nos dias atuais. Rio de Janeiro: CELD COSTA, Flavio Moreira da (Org.) (2009). Contos de Vampiros. Clássicos escolhidos. Rio de Janeiro: Agir Editora.

DEL PRIORE, Mary (2014). Os do outro lado. A história do sobrenatural e do espiritismo. São Paulo: Planeta.

DONALD, James (2000). "Pedagogia dos monstros: o que está em jogo nos filmes de vampiro?" In: COHEN, Jeffrey Jerome. Pedagogia dos monstros - os prazeres e os perigos da confusão de fronteiras. Tomaz Tadeu da Silva (Trad.). Belo Horizonte: Autêntica. p.105-140.

DUBY, Georges (1998). Ano 1000, ano 2000. Na pista de nossos medos. Eugênio Michel da Silva (Trad.). São Paulo: Fundação Editora da UNESP.

ÉLIS, Bernardo (2005). “As morféticas". In: . Ermos e gerais. São Paulo: Martins Fontes. p.239-247.

FERRANTE, Vera Lúcia et al (2013). "Na trajetória dos assentamentos rurais: mulheres, organização e diversificação". In: NEVES, Delma Pessanha et al (Org.). Mulheres camponesas: trabalho produtivo e engajamentos políticos. Niterói: Alternativa. p.195-216.

LE FANU, Sheridan. (2009). "Carmilla” In: COSTA, Flavio Moreira da (Org.). Contos de Vampiros. Clássicos escolhidos. Rio de Janeiro: Agir Editora. p.69-180.

LECOUTEUX, Claude (2005). História dos vampiros. Autópsia de um mito. Álvaro Lorencini (Trad.). São Paulo: Editora UNESP.

LUGONES, María (2014). "Rumo a um feminismo descolonial". Estudos Feministas, Florianópolis, 22(3). 935-952, set./dez.

OLIVAO, Moema de Castro e Silva (1975). "Prólogo". In: ÉLIS, Bernardo. Caminhos dos Gerais: contos. Rio de Janeiro: Civilização Brasileira. s/p.

RICE, Anne (2018). Entrevista com vampiro. Clarice Lispector (Trad.). In http:// avulsos.hime-chan.com/anne-rice/1.pdf. Acesso em 22.dez.2018

ROBLES, Martha (2006). "Lilith". In - Mulheres, mitos e deusas. 0 feminino através dos tempos. William Lagos; Débora Dutra Vieira (Trad.). São Paulo: Aleph. p.33-36. 
SOUZA, Candice Vidal (1997). A pátria geográfica: sertão e litoral no pensamento social brasileiro. Goiânia: Ed. da UFG.

(2010). "O sertão amansado". Sociedade e Cultura, Goiânia, 13(1), 101110, jan./jun. Acesso em 16.dez.2018.

TELES, Gilberto Mendonça (2007). O conto brasileiro em Goiás. Goiânia: Editora da UCG.

VAN GENNEP, Arnold (2011). Os ritos de passagem: estudo sistemático dos ritos da porta e da soleira, da hospitalidade, da adoção, gravidez e parto, nascimento, infância, puberdade, iniciação, coroação, noivado, casamento, funerais, estações, etc. Mariano Ferreira (Trad.). Petrópolis, RJ: Vozes.

VICENTINI, Albertina (1998). "O sertão e a literatura". Sociedade e Cultura, Goiânia, 1(1), p.41-54, jan./jun. In https://www.revistas.ufg.br/fchf/article/ view/1778. Acesso em 16.dez.2018. 


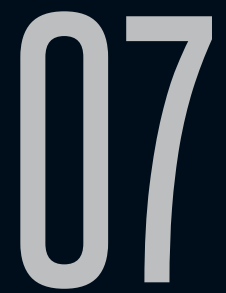

\section{O VAMPIRO COMO METÁFORA NA LITERATURA BRASILEIRA OITOCENTISTA}

Ana Paula Araujo dos Santos (UERJ)

Recebido em 13 mar 2019. Aprovado em 22 mai 2019.
Ana Paula Araujo dos Santos é Doutoranda em Teoria da Literatura e Literatura Comparada pela UERJ, com a pesquisa intitulada "A vertente feminina do Gótico nas literaturas britânica e brasileira". É bolsista CAPES, membro do grupo de pesquisa "Estudos do Gótico" (CNPq) e integrante do GT "Vertentes do Insólito Ficcional". É autora da dissertação $O$ Gótico feminino na Literatura Brasileira: um estudo de Ânsia eterna, de Júlia Lopes de Almeida (2017) e coorganizadora do livro As Artes do Mal: Textos Seminais (2018), publicado em conjunto com o Prof. Dr. Júlio França. Seus artigos mais recentes podem ser encontrados na página "Sobre o Medo" (sobreomedo.wordpress.com). Lattes: http://lattes.cnpq. br/0205036448892276. E-mail: ana_ads@hotmail.com.

Resumo: Nas literaturas de língua inglesa e na literatura francesa o interesse pelo mito do vampiro pode ser facilmente observado na ampla produção ficcional do século XIX e XX. Já no Brasil, até a metade do século $X X$ não houve uma produção sistemática de uma ficção que explorasse o mito do vampiro semelhante à da Inglaterra e da França. Contudo, a figura do vampiro se faz presente em obras brasileiras que exploram o seu potencial simbólico. Nelas, o vampiro aparece como figuração de morte, doenças e maldades. O presente artigo visa a uma análise dessas obras, mais especificamente dos contos "A esteireira" (1898), de 
Afonso Arinos, e "Noites brancas" (1920), de Gastão Cruls, além do romance A mortalha de Alzira (1891), de Aluísio Azevedo. As leituras propostas focarão em elementos característicos da temática do vampirismo na literatura: misteriosos encontros noturnos, femme fatales, desregramentos sexuais, perigos de doença e de contágio. Tais características funcionarão como ponto de partida para uma reflexão sobre as razões da suposta ausência, na literatura brasileira oitocentista, daquele que é um dos personagens mais recorrentes na literatura do mal e do medo e da literatura gótica.

Palavras-chave: Narrativa; Século XIX; Literatura Brasileira; Vampiros.

Abstract: In English and French literature, the interest in the myth of the vampire can be easily found in the vast fictional production published throughout the nineteenth and twentieth centuries. However, in Brazil, until the middle of the twentieth century there was no systematic production of fictional works that explored this myth in a similar way, although the vampire is present in Brazilian narratives that explore its symbolic potential. In these narratives, the vampire appears as a representation of death, diseases and evil. This paper aims at analyzing these works, specifically the short stories "A esteireira" (1898), by Afonso Arinos, and "Noites brancas" (1920) by Gastão Cruls, and also the novel A mortalha de Alzira (1891) by Aluísio Azevedo. The readings will focus on characteristic elements of vampirism in literature: mysterious nocturnal rendezvous, femme fatales, sexual transgressions, and the perils of diseases and contagion. These elements will guide a reflection about the possible reasons for the supposed absence in the nineteenth and early twentieth centuries Brazilian literature of one of the most recurrent characters in Gothic literature and the fiction that deals with evil and fear.

Keywords: Narrative; Nineteenth century; Brazilian literature; Vampires. 


\section{INTRODUÇÃO}

Por conta de sua constante presença na literatura, nas artes plásticas, no cinema, nos quadrinhos e em diversas outras produções artísticas, o vampiro assume uma existência quase mitológica em diversas culturas. Sua figura arquetípica não conhece barreiras geográficas nem temporais: pode ser encontrada nas narrativas orais e nas lendas de diversos países, e aparece metamorfoseado em muitas formas, nas mais diferentes épocas. Nick Groom (2018, p.XVIII-XIX) aponta que, no complexo folclore que cerca essa criatura, os vampiros se confundiram com uma série de outros seres sobrenaturais, tais como strix ou strigoi, lobisomens, revenants, espíritos noturnos $(A / p)$, bruxas e demônios. Além dessas criaturas, as mitologias egípcia, hebraica e mesmo a chinesa e a africana também possuem histórias de outros monstros malignos que têm em comum o fato de se alimentarem de sangue.

A pletora de ocorrências folclóricas relacionadas ao vampirismo ajuda a explicar não apenas a fascinante mitologia gerada em torno dessa figura, mas também as múltiplas faces que o vampiro assumiu - e continua assumindo - ao longo de sua existência cultural. Nas palavras de Nina Auerbach ${ }^{1}$ :

Mesmo antes de Drácula tornar-se foco das atenções com o início do século $X X$, os vampiros escaparam de resumir-se a uma única identidade. Eles eram portadores de paixões sensuais ou de doenças devastadoras; velhos de faces arroxeadas que devoravam seus filhos; donzelas suspirantes que às vezes se tornavam serpentes; impetuosos companheiros de jovens inquietos; ou mesmo plantas. $(2009$, p.4)

1 A exemplo desta, todas as demais citações em língua inglesa encontram-se em traduções minhas. 
A despeito de suas inúmeras caracterizações, as histórias sobre os vampiros convergem para um ponto em comum: seus personagens principais são mortos que voltam ao mundo dos vivos e atacam as suas vítimas à noite, em busca de sangue. Esse modus operandi particular foi visitado e revisitado por muitas narrativas literárias relacionadas ao mal, ao medo e ao Gótico. Afinal, interessada em provocar prazer estético por meio de emoções como o medo, o horror, o terror, a repulsa e a angústia, essa literatura de cunho negativo encontrou no vampiro um de seus mais ameaçadores e eficazes personagens vilanescos.

Esse interesse pode ser facilmente observado na ficção produzida ao longo do século XIX e XX. Em língua inglesa, o poema "Christabel" (1797-1816), de Samuel T. Coleridge, e o conto "O vampiro" (1819), de John Polidori, são apontados como textoschave para a inauguração de uma tradição vampírica na literatura. Porém, uma miríade de outras obras literárias em verso e em prosa se juntou a esses títulos, dentre os quais podemos citar como exemplos: "A Lâmia" (1819) e "La Belle Dame Sans Merci" (1819), de John Keats - poemas que apresentam sutis ligações com o tema do vampiro -, Carmilla (1872), de Sheridan Le Fanu, e Drácula (1897), de Bram Stoker. Na literatura francesa, o poema "As metamorfoses do vampiro", de Charles Baudelaire, e o conto "A morta amorosa" (1836), de Théophile Gautier, são exemplos significativos, em língua francesa, de uma ficção de temática vampiresca.

No Brasil oitocentista não houve uma produção sistemática de obras que explorassem o mito do vampiro semelhante à Inglaterra e à França. Contudo, a figura do vampiro se faz presente em obras brasileiras que o exploraram de forma simbólica. Nelas, o vampiro 
aparece como figuração de morte, doenças e maldades. São exemplos desse uso particular do arquétipo vampírico "A esteireira" (1898), de Afonso Arinos, o romance A mortalha de Alzira (1891), de Aluísio Azevedo, e "Noites brancas" (1920), de Gastão Cruls, que, publicado no início do século $X X$, é uma produção que possui evidentes características da nossa literatura oitocentista. Por meio da leitura dessas obras pretendo, ao longo deste ensaio, empreender uma breve reflexão acerca do uso metafórico do vampiro nessas narrativas e investigar as possíveis causas que contribuíram para impedir a difusão dessa criatura na literatura brasileira².

\section{DO MITO AO MONSTRO}

Antes de dar prosseguimento à análise do corpus ficcional, julgo necessário tecer algumas considerações sobre as características do vampiro na ficção. Sobre esse assunto, concordo com o teórico Jeffrey Jerome Cohen, para quem uma compreensão mais aprofundada das monstruosidades na literatura pressupõe também uma análise da cultura e das condições nas quais ela foi gerada. Cohen (2000, p.26) defende que é possível entender o monstro como uma "corporificação de um certo momento cultural - de uma época, de um sentimento e de um lugar". Essa afirmação se prova assaz correta no que diz respeito às criaturas vampíricas.

Em seu ensaio, o teórico frequentemente utiliza o vampiro como exemplo de personagem monstruosa - e não por acaso.

2 Uma versão prematura dessa exposição pode ser encontrada no artigo intitulado "Encontros noturnos em 'Noites Brancas', de Gastão Cruls: traços do vampirismo na literatura brasileira", publicado em "As arquiteturas do medo e insólito ficcional", nos Anais do XII Painel Reflexões sobre o insólito na narrativa ficcional (2014). Pretendo, com este trabalho, não apenas expandir as análises outrora empreendidas ao corpus ficcional referenciado, mas, também, desenvolver mais profundamente algumas das hipóteses conjecturadas nesse artigo. 
Ele demonstra que, em suas mais diversas aparições ficcionais na literatura e no cinema, o vampiro foi um monstro utilizado para representar diferentes ansiedades presentes em nossa sociedade. A ameaça representada por essa criatura tomava a forma de muitos dos nossos medos em relação à tirania e às enfermidades, e de nossas angústias ligadas à xenofobia, às práticas sexuais consideradas transgressivas, ao sadismo e à homossexualidade (COHEN, 2000, p.28-9). Tal como outras personagens monstruosas, ao encarnar uma variedade de transgressões socioculturais, ele demarca o que é tabu - e, a um só tempo, reafirma o que não é para a nossa cultura, para a nossa época.

Para Luciano Cabral (2017, p.220), a marca de alteridade seria, portanto, um dos traços definidores das monstruosidades ficcionais:

Quando enxergamos em outras pessoas características compatíveis com as nossas - sejam elas de ordem geográfica, linguística, cultural, étnica, sexual, econômica, política, social -, sentimo-nos seguros e, como não percebemos perigo, aproximamo-nos. Ao contrário, o que não se encaixa em nossos parâmetros de normalidade, por ser diferente, é combatido e rechaçado. Podemos dizer que é justamente nessa diferença onde residem os monstros. (CABRAL, 2017, p.221)

O vampiro - bem como os demais monstros em geral - seria um símbolo do que é diferente, e funcionaria como um indicador da alteridade. Esse é precisamente um entre os muitos motivos pelos quais os monstros nos suscitam receios. Porém, a sua alteridade não é apenas um atributo negativo. Se assim fosse, eles constituiriam uma ameaça mais óbvia, e, talvez, mais fácil de ser exterminada. No entanto, 
[p]or estarem associados a práticas proibitivas e transgressoras, monstros carregam em sua essência uma dupla característica: por violarem normas estabelecidas, são sempre perturbadores e ameaçadores e, pelo mesmo motivo, são sedutores e atraentes. Eles repelem na mesma proporção em que fascinam. (CABRAL, 2017, p.221)

Ao demarcar os limites do que é aceitável e do que é condenável e corporificar tabus sociais, o monstro realiza ficcionalmente muitas das nossas fantasias de violência e transgressão. Eles nos atraem por sua liberdade, porque, diferente das nossas, suas ações são irrestritas e não seguem os ditames sociais.

Além disso, entre os personagens monstruosos, os vampiros, em especial, adquiriram ao longo de sua existência literária uma aparência física sedutora. Muitos deles não possuem traços físicos repulsivos comuns a alguns monstros, mas, em vez disso, são dândis e femme fatales cuja beleza é responsável por atrair as suas vítimas a despeito do perigo que representam para elas. A emblemática passagem de Drácula em que Jonathan Harker se depara com as três vampiras prontas para "beijá-lo" é decerto um dos exemplos que melhor sumarizam o dúbio efeito do vampiro sobre suas presas:

As três damas tinham dentes alvos e brilhantes, que cintilavam nos lábios voluptuosos como pérolas sobre rubis. Havia algo naquelas mulheres que me perturbava: elas me provocavam uma inquietante mescla de atração e medo. Senti o perverso e sulfuroso desejo de que me beijassem com aqueles lábios vermelhos. 
Eu jazia imóvel, com os olhos semicerrados, espiando sob as pestanas, na angustiosa delícia da antecipação. Avançando, a moça loira se curvou sobre o meu corpo, e senti o toque de seu hálito - doce, sim, com ressaibos de mel que tilintaram em meus nervos como as notas de sua voz; mas no fundo daquela doçura havia um toque amargo e ofensivo, como um acre vestígio de sangue. (STOKER, 2014, p.107)

A reação de Harker diante do ataque é digna de nota: mesmo pressentindo o perigo, ele não resiste à sedução das vampiras. No excerto, fica claro que a beleza física e a luxúria das personagens monstruosas não excluem o terror da cena em que o prazer se mistura com o medo. Logo, se em alguns personagens monstruosos a aparência física repulsiva é uma marca de sua diferença em relação aos seres humanos e sinalizam o mal que podem causar a eles, em uma grande parte dos vampiros os atributos físicos são antes um disfarce, uma forma de atrair suas presas.

Essas reflexões ajudam a compreender as características que permitem considerar o vampiro como um monstro. Ora aterrorizantes ora fascinantes, o perigo representado pelos vampiros ficcionais vai além do mito. Demonstrarei a seguir que as características desse personagem arquetípico da literatura do mal não se restringem apenas ao ato de beber o sangue de suas vítimas, pois ele está ligado, também, a temas recorrentes da condição humana: a morte, a sexualidade e as enfermidades. É por meio desses topoi que a literatura brasileira do século XIX e do início do XX dialoga com a tradição das narrativas vampíricas. 


\section{PORQUE A ALMA DA CARNE ESTÁ NO SANGUE}

Afirmei anteriormente que o mito dos vampiros inclui uma grande variedade de criaturas sobrenaturais que possuem em comum a sede por sangue. Os simbolismos atribuídos a esse fluido vital não são poucos: sugar o sangue é, muitas vezes, descrito como um ato erótico, sádico, que mistura prazer e horror; noutras é descrito como um pecado, pois, conforme os versículos de Levítico (17:11), "a alma da carne está no sangue" (BÍBLIA, 1992, p.163). Assim, beber o sangue de outrem não é apenas letal, mas, também, algo vil e repulsivo.

As narrativas vampíricas costumam explorar os horrores advindos desse ato, ora de forma mais sutil ora de forma mais explícita. É por essa via que podemos considerar o conto "A esteireira", de Afonso Arinos, uma narrativa que dialoga com a tradição vampírica. Ainda que a criatura não seja mencionada diretamente nessa obra, a sede por sangue é o clímax da trama e é descrita de forma minuciosa como forma de horrorizar os leitores.

No conto, a protagonista de Arinos, Ana, é conhecida pela alcunha de esteireira por conta do pai, que fazia esteiras de taquara (ARINOS, 2006, p.52). Ela é apresentada para os leitores como uma mulher sensual e de personalidade forte. Sua descrição física, logo ao início da narrativa, é carregada de erotismo:

Era uma mulata de estatura regular, cheia de corpo, cadeiras largas e braços grossos. TremiamIhe as nádegas a seu passo forte. (...) OstentavaIhe invariavelmente o colo de nhambu, descoberto, aparecendo os seios duros, saltitantes, presos no bico pela renda da camisa alva. 
Tinha a pele macia e a carnadura cheia de viço que transudavam seus lábios vermelhos, sempre úmidos. As linhas do rosto, corretas que eram, representavam no conjunto de seu corpo o cunho da raça caucasiana. Esse conjunto aliava à graça da europeia a sensual indolência d'África.

Era provocadora - a mulata! (ARINOS, 2006, p.51-52)

Essa descrição faz com que associemos a esteireira a uma femme fatale. Esse arquétipo é conhecido por possuir uma beleza irresistivel, responsável por atrair os outros personagens e leválos à perdição e/ou à morte. Por conta disso, muitas das vampiras são consideradas femme fatales. A título de comparação, vale reproduzir aqui a cena em que Christabel, do poema homônimo de Coleridge, assiste Geraldine se despir:

Ela se ergueu, apoiada em seu cotovelo,

Para observar a donzela Geraldine.

Abaixo do lustre a dama se curvou,

E lentamente seus olhos se viravam;

E então fazendo cessar a respiração,

Como alguém que treme, ela desfez

A fita que trazia logo abaixo do colo:

Seu vestido de seda, e a anágua,

Caíram a seus pés, e inteira à mostra,

Oh! Seu peito e suas costelas -

Visão de sonho, não há palavras para ela! (COLERIDGE, 2010, p.249)

Embora mais sutil que a descrição dos atributos físicos da esteireira, a cena voyeurística é igualmente carregada de erotismo, e serve para destacar o encanto produzido por meio da beleza da vampira de Coleridge. Em ambos os casos, a identificação das personagens como femme fatales será importante para o 
desenvolvimento das narrativas, pois reafirmam o dúbio efeito causado pelas vampiras: elas são tão belas quanto são fatais.

Se é possível ser atraído pela beleza da esteireira, o desenvolvimento da trama evidencia que ela é uma mulher perigosa. Perdidamente apaixonada por Filipinho, um rapaz genioso, atrevido e envolvido com outros bandidos locais (ARINOS, 2006, p.53), Ana não admite que o seu amado flerte com outra mulher senão com ela. O narrador deixa claro que ela "era orgulhosa. Amava a Filipinho, julgando-o todo seu, dela só" (ARINOS, 2006, p.58). Essa paixão possessiva será o motivo que irá aproximar a personagem do vampirismo. Desconfiada de traição, Ana começa a revelar uma personalidade maligna que é simbolizada sobretudo pelos seus olhares:

Ao despedir-se do mulato, Ana, puxando-o pelos dedos e fixando nos dele seus grandes olhos negros, queimados de zelo, perguntou-lhe se não era exato ter ele dado umas bichas de ouro à Candinha do Fundão e estar inclinado a gostar dela. (ARINOS, 2006, p.55 - grifos meus)

Ana apareceu nesse dia, como sempre, asseada, com a saia de uma limpeza sem par. Trazia nos olhos um brilho estranho; seus olhares pareciam ferir como os espinhos dos gravatás, sobre os quais ela estendia algumas vezes a roupa.

É que o ciúme lhe trabalhara a alma todo o tempo decorrido desde a véspera.

(ARINOS, 2006, p.57 - grifos meus)

A vileza denunciada pelo olhar da esteireira é o primeiro indício do ato mau que ela está para cometer. No início do conto, nós, leitores, somos levados a acreditar que ela era apenas uma mulher de gênio forte, provocadora, mas o ciúme irá transfigurá- 
la em uma monstruosidade vampírica. Ana prepara uma armadilha para Candinha, sua suposta rival. Convida-a para um passeio que terminará no assassinato desta última:

Ana, sem que a companheira o percebesse, saca de uma navalha e, vibrando-a com a mão rápida e firme, corta a carótida à infeliz companheira, que estava unida a si, abraçada à sua cintura, na garupa do animal. Caíram ambas, e Ana, não querendo que na estrada houvesse grande marca de sangue, encostou os lábios ao lugar de onde irrompia aos cachões, e, carnívora esfaimada, chupou, chupou por muito tempo, carregando, depois, o corpo da desventurada para bem longe, onde um desses precipícios, cavados pelas enxurradas, recebeu-o no fundo da sua fauce. (ARINOS, 2006, p.60)

O narrador faz questão de apontar que o ciúme de Ana era infundado (ARINOS, 2006, p.58). Isso faz que com que o assassinato cometido por ela seja visto como um ato ainda mais maligno, afinal, há um descompasso entre a gravidade da transgressão cometida e a débil motivação do crime perpetrado pela esteireira (FRANÇA \& SANTOS, 2018, p.14).

Portanto, o que chama a atenção nessa transgressão é que a sua execução vai além de um mero crime. Ana ataca justamente a carótida de Candinha e suga o sangue com uma inexplicável sede. A justificativa para esse estranho comportamento provém do temor de que fossem deixados rastros do assassinato que a esteireira acabara de cometer - em nenhum momento temos alguma menção explícita a um ato de vampirismo. Contudo, é inevitável não relacionar a sede de Ana por sangue e o prazer com que ela parece beber o fluido vital da rival com um comportamento vampírico. Se o vampirismo 
não é mencionado diretamente no conto, ao menos é possível, em uma leitura atenta da obra, apontá-lo metaforicamente. Afinal, Ana, no clímax da narrativa, pouco diverge das vampiras do castelo de Drácula, de Lucy Westenra, de Carmilla ou de outras vampiras célebres. Seu aspecto vilanesco e monstruoso advém da mesma fonte que confere a monstruosidade a essas personagens: o fato de não apenas aniquilarem a sua vítima, mas fazê-lo ao ingerir a essência desta, isto é, o fluido vital do sangue.

\section{PORQUE O AMOR É MAIS FORTE DO QUE A MORTE}

O emprego metafórico do vampiro em "A esteireira" não é um caso isolado na literatura brasileira. Se, no conto de Afonso Arinos, o vampirismo simboliza um ato extremo de maldade cometido pela protagonista da trama, nas duas outras obras analisadas neste trabalho, esse personagem arquetípico irá incorporar outras facetas às quais o vampirismo está ligado - o sexo, as doenças e a transmissão delas do algoz para a sua vítima.

Em A mortalha de Alzira, Aluísio Azevedo homenageia o célebre conto vampiresco de Théophile Gautier, "A morta amorosa". Em ambas as narrativas, um jovem padre, puro e devotado a Deus apaixona-se por uma cortesã. O casal se reúne somente após o falecimento desta última, que volta ao mundo dos vivos todas as noites à procura do amado - provando, assim, que "o amor é mais forte do que a morte" (GAUTIER, 2010, p.148).

Embora compartilhem a mesma trama, as duas obras se desenvolvem de forma bastante distintas. No conto de Gautier, o padre Romualdo, o protagonista, é alertado que a cortesã Clarimunda é um ser demoníaco, uma vampira, e que teria morrido 
mais de uma vez (GAUTIER, 2010, p.146). Se de início Clarimunda aparece para ele como se fosse um sonho, a confirmação de que a femme fatale é real e um ser monstruoso ratifica que ela é uma ameaça para Romualdo, pois ela passa a se alimentar de seu sangue:

O sangue logo caiu em filetes purpúreos e algumas gotas jorraram em Clarimunda. Seus olhos se iluminaram, sua fisionomia tinha uma expressão de alegria feroz e selvagem como eu jamais vira. Saltou da cama com uma agilidade animal, uma agilidade de macaco ou de gato e se precipitou sobre o ferimento, que começou a sugar com indizível volúpia. Engolia o sangue em pequenos goles, lenta e preciosamente, como um gourmet um vinho de Xerez ou de Siracusa (...). De vez em quando, ela interrompia para beijar a minha mão, depois voltava a pressionar contra a ferida os seus lábios, para extrair ainda algumas gotas vermelhas de sangue. (GAUTIER, 2010, p.155)

- Eu não morrerei! Não morrerei! - disse ela meio louca de alegria, pendurando-se em meu pescoço. - Poderei te amar ainda por muito tempo. Minha vida está na tua, e tudo o que eu sou vem de ti. Algumas gotas de teu sangue rico e nobre, mais precioso e eficaz do que todos os elixires do mundo, me proporcionam a existência! (GAUTIER, 2010, p.156)

Com o passar do tempo, Clarimunda mantém-se viva apenas por meio do sangue do padre, porém, este último perde, aos poucos, a própria vida: é consumido pelo cansaço, pela angústia e pelos remorsos do romance com a morta-viva. O pesadelo de Romualdo só termina quando o seu guardião, o padre Serapião aniquila a vampira ao jogar água benta em sua tumba. O conto de Gautier realiza-se como uma clássica narrativa vampírica não apenas pelo 
ritual de extermínio da personagem, mas também porque na literatura - tanto quanto no cinema - a eliminação do vampiro é o clímax desse tipo de narrativa (LECOUTEUX, 2005, p.139).

Já no romance de Azevedo - tal como no conto de Arinos não há nenhuma menção direta ao vampirismo. Em um primeiro momento, a compreensão de A mortalha de Alzira como uma narrativa vampírica deve-se apenas ao inegável paralelismo com o conto de Gautier: todos os principais personagens e situações de "A morta amorosa" encontram seus correspondentes n'A mortalha excetuando-se a confirmação da femme fatale como uma vampira. Apesar disso, concordo com Marina Sena (2017, p.106), para quem a sugestão de vampirismo não foi completamente excluída do romance azevediano. A eliminação do elemento sobrenatural não impede que o vampiro seja explorado de outra forma ao longo da narrativa, como pretendo demonstrar a seguir.

No romance de Azevedo, o padre Ângelo, o protagonista, foi uma criança órfã adotada pelo padre Ozéas, que o tomou por um enviado divino, um messias para salvar a corrupta Paris do século XVIII. Ângelo foi criado dentro do convento, "fechado na sua religiosa estufa, sem ter nem ao menos desconfiança do que se passava lá fora (...)" (AZEVEDO, 1894, p.19). Até os vinte anos cresceu casto, conhecendo apenas a religião e a Bíblia (AZEVEDO, 1894, p.20). Sob a rígida educação de Ozéas, o jovem Ângelo foi afastado de todo e qualquer contato com o sexo de modo a permanecer fiel à vocação religiosa.

Essa informação é importante porque, segundo David Brown, Azevedo teria racionalizado os elementos de "A morta amorosa" não por acaso, mas com o intento de dar ao enredo uma configuração naturalista: 
No momento em que escrevia $A$ mortalha de Alzira, Aluísio Azevedo já era uma espécie de autoridade no que se referia à questão de dupla personalidade e à vida onírica das pessoas que, à noite, põem de lado suas inibições diurnas. De fato, toda a trama de uma de suas principais obras, 0 Homem (1887), foi arquitetada quase inteiramente em torno desse fenômeno psicológico, que é visto por Azevedo como uma manifestação de histeria. Não é surpreendente, portanto, que, ao escrever sua versão de A morta amorosa, Azevedo tenha escolhido essa explicação racional para o fenômeno documentado. (1945, p.253)

Mais interessado em explorar uma patologia do que um caso sobrenatural, Azevedo demonstra, em A mortalha de Alzira, como a privação sexual do padre Ângelo culmina em esquizofrenia e violência (BROWN, 1954, p.255). Esse tipo de narrativa não é incomum às obras naturalistas, que frequentemente postulavam a melancolia, a loucura e a morte como as sinas mais frequentes dos personagens aos quais era imposta a privação sexual (MENDES, 2016, p.345-346).

É nesse sentido que Ângelo, inexperiente e dotado de uma imaginação fantasiosa, irá gradativamente adoecer diante da impossibilidade de realizar os impulsos amorosos despertados pela cortesã Alzira. Na ocasião do primeiro encontro entre ambos, o jovem é fulminado por desejos que até então lhe eram desconhecidos, e, como resultado, é tomado por uma série de reações tipicamente atribuídas a personagens histéricos e/ou acometidos por alguma nevrose: convulsões, soluços, tremores e um contínuo choro (AZEVEDO, p.68-69). Tal reação não é sem motivo, afinal, até então Ângelo pouco conhecia do mundo, e, 
encerrado no claustro, permanecera ignorante às mulheres. A exposição a uma femme fatale como Alzira - uma "bela, cínica e espirituosa cortesã" (AZEVEDO, 1894, p.43) disputada por "toda a gente da corte capaz de manter mulheres caras" (AZEVEDO, 1894, p.43) - opera, no protagonista, uma mudança inevitável. Alzira se torna o objeto da obsessão romântica de Ângelo, o alvo de desejos inconciliáveis com a sua posição religiosa.

Tamanha obsessão leva o padre a sentir a presença de Alzira sempre que se encontra a sós (AZEVEDO, 1894, p.164-165). Logo, desde o início do affair entre ambos, Alzira assume um papel fantasmagórico: ela parece assombrar e ameaçar o padre, tal como um ser sobrenatural. Por conta disso, Ângelo se torna mais taciturno, mais fraco e mais infeliz diante da incapacidade de controlar a paixão e a luxúria despertadas pela cortesã (AZEVEDO, 1894, p.160). Essa situação tomará proporções ainda mais graves a partir do falecimento de Alzira. Alucinado, o padre principia a vê-la retornar da morte:

E uma vertigem se apoderou dele, e o seu sangue enlouqueceu, acendendo-Ihe os sentidos, e apagando-Ihe naquele instante a luz da razão.

Soltou um grito. Aos seus olhos desvairados, Alzira acabava de erguer-se a meio no leito, e abriu as pálpebras, estendendo-lhe os braços com um fugitivo e triste sorriso nos lábios.

- Meu Deus! meu Deus! exclamou ele, trêmulo e aterrorizado. Que significa isto?... Ainda vives, Alzira?... mas como é que vives, se o teu corpo tem a gelidez da morte?...

E Ângelo viu distintamente que os lábios dela se moviam, para lhe responder com uma voz quase indistinguível: 
- Sim, vivo ainda... um instante apenas, um ligeiro instante; o que baste para encher minha alma com a tua imagem imaculada e santa, antes que eu parta eternamente para as margens desconhecidas que já daqui avisto... (AZEVEDO, 1894, p.175-176)

A narrativa deixa evidente que os abalos nervosos e as alucinações de Ângelo não possuem origem sobrenatural, mas sim patológicas. Ele é, logo a seguir, diagnosticado como histérico, condição que teria desenvolvido por conta da imposição de pureza e castidade ao seu corpo e à sua alma. Nesse estado ele estaria sujeito a toda espécie de sonhos extravagantes, delírios, visões e fantasias (AZEVEDO, 1894, p.181-182). E é precisamente isso que acomete Ângelo ao longo da narrativa azevediana. Após a morte de Alzira, todas as noites, ao se deitar para dormir, ele passa a sonhar com a amada. Nesses sonhos, tal como uma rediviva, Alzira atravessa o mundo dos mortos e retorna ao mundo dos vivos. Fria como um cadáver, sua "nova existência" - exclusivamente noturna, pois se mantém presa ao sepulcro durante o dia - depende unicamente do calor do sangue de Ângelo e tem como objetivos fazer o padre gozar a vida profana que lhe fora negada e se entregar, finalmente, ao amor da cortesã (AZEVEDO, 1894, p.204-205).

Assim, embora Alzira não seja apontada como vampira, nos sonhos de Ângelo ela encarna perfeitamente esse arquétipo de personagem. O suposto retorno da cortesã ao mundo dos vivos torna-se o vetor para os delirantes desejos do histérico padre, que, todas as noites, sonha estar na companhia da amada, vivendo de forma extravagante durante a noite, repleto de luxúria, ambição e violência - uma vida incompatível com o cotidiano religioso diurno. O auge dessa dupla existência, e, também, da sugestão vampírica no 
romance azevediano, é a cena em que o padre, tomado de ciúmes, assassina um ladrão que ameaça roubar-lhe a amante:

- Hás de morrer! tornou o outro, abrasado de cólera. Nunca mais terás olhos para cobiçar a minha amante.

E, arrancando contra ele, atravessou-Ihe o peito com uma punhalada.

- Ai! gemeu o salteador agonizando.

- Fujamos! segredou Alzira, puxando o amante pelo braço.

- Não! Hei de beber-lhe primeiro o sangue! Hei de beber o sangue de todo aquele que pretende arrancar-te de meus braços!

E vergou-se sobre o cadáver, colando-Ihe os lábios à ferida que sangrava.

- Ângelo! Ângelo! Partamos! Olha que aí vem o dia! exclamou a cortesã.

O pároco ergueu então a cabeça e notou que, com efeito, em volta dele tudo começava a esbater-se à luz da aurora. O próprio cadáver, de cuja ferida ele acabava de despregar a boca cheia de sangue, nada mais era que uma transparente sombra, estendida a seus pés. (AZEVEDO, 1894, p.245)

Tal como em "A esteireira", a sede por sangue surge de um grave crime cometido pelo protagonista. Porém, não é a personagem vampírica que sucumbe à sede, mas o próprio protagonista. Embora em seu próprio sonho Ângelo tenha agido em legítima defesa, a sua motivação parece débil se comparada ao ato vampírico de beber o sangue da vítima e à ferocidade com que o padre o faz. Conforme chamei atenção anteriormente - ao analisar "A esteireira" -, 
também n'A mortalha a narrativa explora a descrição de beber sangue de uma vítima como forma de suscitar repulsa em seu leitor.

O romance de Azevedo se torna gradativamente mais sombrio à medida que a violenta e sensual vida noturna do padre passa a imperar sobre a sua vida religiosa. No epílogo da história, Ângelo descobre que sua vampírica companheira noturna e os sonhos extravagantes não eram senão uma ilusão, um produto de sua mente doente que desejava, sobretudo, dar vazão ao amor impossível de ser realizado quando Alzira estava viva. O jovem padre colapsa diante de tal verdade. Sem forças para encarar o que era real, ele se suicida, preferindo antes o sono eterno a uma vida sem sonhos (AZEVEDO, 1984, p.320).

Diante do exposto, é possível confirmar a hipótese que propus no início desta seção: Azevedo não deixa de explorar, em seu romance, o elemento central do vampirismo, isto é, o tabu do sangue e a repulsão causada por se alimentar desse líquido vital. Mesmo sem ratificar Alzira como uma vampira, a confirmação da monstruosidade sobrenatural é dispensável na narrativa, uma vez que a personagem assume características vampíricas, é descrita e age como uma rediviva. A personagem de Azevedo possui, sobretudo, a mesma função atribuída às outras vampiras ficcionais: é por meio de sua sedução que os personagens da narrativa caem em desgraça, enlouquecem e/ou morrem.

\section{PORQUE O BEIJO É A VÉSPERA DO ESCARRO}

A predominância de um ambiente noturno e a sede por sangue humano são as constantes da tradição literária ligada ao vampirismo - mesmo quando os personagens não são diretamente 
classificados como vampiros, mas podem ser entendidos dessa forma. Esse binômio é o cerne das narrativas vampíricas, e sobre ele é arquitetado "Noites Brancas", de Gastão Cruls. A trama é, de fato, tão semelhante às histórias vampíricas que a menção a essas criaturas não escapa à narração, em uma sugestão que não parece de modo algum gratuita.

No início do conto, o protagonista, Carlos de Azambuja, um estudante de quase dezoito anos, recebe um misterioso bilhete que lhe propõe o seguinte convite: "Carlos - Se tu queres conhecer a volúpia de meus beijos, deixa a tua porta aberta e, esta noite, quando todos dormirem, no mistério da treva e do silêncio, eu te virei proporcionar o mais lindo sonho de amor" (CRULS, 1951, p.59).

O bilhete, ao mesmo tempo em que "encalmava o sangue, acendendo-Ihe nas veias o fogo da luxúria" (1951, p.62), cria em Carlos uma hesitação que possui motivações morais: tendo ele se hospedado na fazenda do Coronel Jesus - onde as únicas presenças femininas eram a esposa do Coronel, D. Clarice, e as filhas Olga e Leonor -, obedecer à sua remetente significaria concordar com um intercurso sexual com uma das três mulheres. Em qualquer um dos casos, o romance seria visto como uma transgressão cometida contra o seu anfitrião. Apesar disso, Carlos, levado pelas tentações inferidas e imaginadas a partir do conteúdo do bilhete, cede ao convite e dá início aos encontros noturnos que se tornam o foco da trama de Gastão Cruls:

Não havia mais dúvidas: a sua porta teria que ficar aberta...

E ficou. Ficou e ela veio, não uma, mas muitas outras noites a seguir. 
Olga? Leonor? D. Clarice? Era o que Carlos não sabia e não cessava de se perguntar a si mesmo, desde a primeira vez em que, mal sopitando de emoção, tateara na treva e retivera entre os braços aquele cálido corpo de mulher, que todas as noites se intrometia no seu leito e lhe oferecia o seio à sofreguidão dos lábios febris. (CRULS, 1951, p.66)

A preferência da amante misteriosa pela noite aproxima-a do modus operandi de vampiros clássicos da literatura como a Carmilla, de Sheridan Le Fanu, e o Drácula, de Bram Stoker, cujos contínuos ataques às suas vítimas acontecem quando estas estão dormindo e possuem implicações inegavelmente sexuais, uma vez que "[o vampiro] não ataca simplesmente visando ao sangue, pois há a presença de um elemento erótico entre ele e sua vítima e os elementos eróticos ou libertinos ganham mais destaque na narrativa do que a necessidade de sangue" (SILVA, 2010, p.28). Um bom exemplo dessa asserção é a descrição de um dos muitos estranhos sonhos em que a jovem Laura, protagonista de Carmilla, é atacada, sem saber, pela célebre vampira dessa obra:

Algumas vezes eu sentia como se alguém passasse a mão ternamente, pelo meu rosto e pelo meu pescoço. Outras vezes, parecia que lábios mornos me beijavam com mais vagar e paixão à medida que se aproximavam de minha garganta, e ali as carícias se concentravam. Meu coração batia aceleradamente, minha respiração se tornava ofegante; surgia então um soluço, que parecia me estrangular e se transformava numa terrível convulsão, durante a qual eu perdia totalmente os sentidos. (LE FANU, 2010, p.96-97)

Ocorrências semelhantes a essa acontecem frequentemente após Laura se deitar para dormir, e são atribuídas à Carmilla, ao 
final da narrativa, quando sua verdadeira identidade vampírica é revelada aos demais personagens da obra. Seguindo essa mesma característica, a analogia entre a visitante noturna de "Noites brancas" e uma criatura vampírica é insinuada pelo narrador, e abre, para o leitor, a possibilidade de interpretar os encontros como eventos sobrenaturais:

Afigurava-se-Ihe mesmo uma negrejante vilania querer supor que aquela figura tão fina, tão angélica, tão espiritual, se pudesse transformar no vampiro luxurioso e insaciável, que todas as noites o possuía furiosamente, a arder na febre de mil desejos. Tão leves eram seus passos e tanta a treva que a cercava, que, não raro, Carlos só pressentia a amante quando ela, já abeirada do seu leito, deixava cair as vestes e uma onda de perfume se Ihe espalhava pelo quarto todo. (CRULS, 1951, p.68 - grifo meu)

Os movimentos leves, quase imperceptíveis da amante de Carlos, sua preferência pelas trevas e a sua rápida fuga ao raiar do dia conferem aos encontros amorosos uma atmosfera fantasmagórica. Somando isso à alusão à criatura sobrenatural, "Noites brancas" parece, de fato, relatar uma narrativa vampírica. Sem conhecer a identidade da visitante noturna, somos inclinados, como Carlos, a acreditar que ela é uma espécie de vampira.

Porém, ao final do conto de Cruls, o suspense acerca da identidade da personagem chega ao fim com um clímax que provoca uma reviravolta inesperada para o protagonista e para o leitor. Uma noite, a misteriosa amante de Carlos falta ao seu encontro, e, na manhã seguinte, o Coronel Jesus informa ao estudante que uma hóspede secreta da fazenda, Maria Clara, irmã de D. Clarice, veio a 
falecer por conta de um mal incurável que a consumia há tempos: a morfeia, doença conhecida hoje como lepra ou hanseníase. A misteriosa e vampírica amante de Carlos não era senão a irmã de D. Clarice, que vivia em segredo na fazenda, consumindo-se pouco a pouco pelo mal infeccioso e altamente transmissível. Após o relato do Coronel Jesus, a lembrança dos encontros noturnos torna-se imediatamente, para Carlos, uma fonte direta de repulsa:

Carlos, à medida que ouvia essa narrativa, sentia o coração aos pulos e sucessivos calafrios de terror Ihe percorriam os músculos. Um suor viscoso inundava-lhe o corpo, que todo se agitava num tremor nervoso.

(...)

Carlos sentia pela primeira vez na boca o travo daqueles beijos, que se muito o fizeram gozar, mais ainda o fariam sofrer. (CRULS, 1951, p.71)

O epílogo do conto recorda a advertência presente nos "Versos íntimos", de Augusto dos Anjos (s/d, p.105): "O beijo, amigo, é a véspera do escarro,/ A mão que afaga é a mesma que apedreja". Afinal, o luxurioso romance que Carlos compartilhara com a suposta vampira transforma-se, rapidamente, em uma projeção dos males que ele viria a sofrer, uma vez contaminado pela mesma doença responsável por causar o isolamento e a morte de Maria Clara.

Apontei, nas análises anteriores, que o vampiro é explorado como figuração de desejos proibidos, maldades e mortes. No conto de Cruls, no entanto, o caráter vampírico da amante de Carlos serve de metáfora para uma grave doença que é transmitida ao protagonista por meio do ato sexual. Esse não é um traço incomum às histórias de vampiro, pois, como informa Nick Groom (2018, 
p.15), "muitos relatos de vampiros associam surtos de vampirismo ao contágio, fazendo deles vetores, e, consequentemente, parte da história das doenças infecciosas." Historicamente, muitas mortes ocasionadas por surtos de doenças epidêmicas - que assolavam a Europa desde a época medieval - foram atribuídas a essas criaturas. Sem uma explicação científica adequada para o contágio e para a propagação desse tipo de doença, essas epidemias foram entendidas como pragas místicas, espalhadas por meio de forças invisíveis, capazes de circular e infectar por meios materiais e imateriais - por palavras, pela respiração e pelo sangue (GROOM, 2018, p.16). A partir daí, surgiu um forte vínculo entre o mito vampírico e as doenças infecciosas.

No caso de "Noites brancas", as peculiaridades da lepra permitem mesmo um paralelo com a própria condição vampírica, cuja maldição é frequentemente transmitida a outrem através do "beijo" do vampiro. Se, ao atribuir a causa dos males da história a uma enfermidade, Gastão Cruls atenua o elemento sobrenatural que permeia sua narrativa, optando por um desfecho realista, não se pode dizer o mesmo em relação à configuração vampírica da misteriosa personagem de "Noites brancas". Tal como Ana, a esteireira, e Alzira, Maria Clara enquadra-se no arquétipo de vampiro ao longo da obra, e, principalmente, em seu desfecho, quando transmite o seu mal a Carlos. Dessa forma, Gastão Cruls explora e mantém até o final da obra elementos que permitem ao leitor qualificá-la como uma história tipicamente vampiresca. 


\section{CONSIDERAÇÕES FINAIS}

Procurei, ao longo deste trabalho, apresentar as características que permitissem considerar os contos de Arinos e Cruls e o romance de Azevedo como obras que dialogam com a tradição da literatura sobre vampiros. Embora as narrativas analisadas não optem pela via sobrenatural - e se furtem a uma confirmação de suas personagens como vampiras -, é inegável que a arquitetura dessas obras abre essa interpretação para os seus leitores. Ademais, cabe aqui parafrasear o que David Punter (1996, p.60) afirma a respeito das obras góticas. Para o teórico, a racionalização dos elementos sobrenaturais de nenhuma forma anula o fato de que os autores góticos exploram o terror e o horror originados das fantasmagorias presentes em suas respectivas obras. Guardadas as devidas proporções, o mesmo pode ser afirmado em relação ao corpus ficcional deste artigo, que explora elementos do vampirismo e os horrores suscitados por essa monstruosidade arquetípica, mesmo que os personagens nem sempre sejam explicitamente apontados como tal.

Ademais, a escolha pelo realismo em detrimento do sobrenatural não é rara em nossa literatura. Em verdade, grande parte da ficção que investia em convenções da literatura gótica ou fantástica recebeu uma severa recepção crítica - foram qualificadas como ficções alienadas, afetadas, exageradas, e os elementos sobrenaturais foram considerados uma transgressão à verossimilhança da narrativa. Logo, esse tipo de ficção foi taxado com baixo valor literário e muitas dessas obras foram excluídas de nossa historiografia.

Suponho, pois, que tal fenômeno ajude a compreender por qual motivo a literatura do século XIX até meados do XX não investiu no 
vampiro ficcional como as literaturas de língua inglesa e a literatura francesa. Aos autores brasileiros restavam poucas opções para a inserção de um tema caracteristicamente sobrenatural como é o tema vampírico. A solução foi transformar o redivivo em metáfora - tal como em "A esteireira", A mortalha de Alzira e "Noites Brancas". Flexível como é o mito do vampiro, ele permitiu sem maiores problemas as figurações de mal e de morte, de sexo e de enfermidades, e de diversos outros aspectos negativos com que lidamos em nossa condição de seres humanos. Por fim, se o vampiro não encontrou no Brasil oitocentista uma terra tão fértil quanto a da Inglaterra, onde pudesse aportar e atacar suas vítimas - à maneira do Drácula de Bram Stoker -, essa criatura deixou certos traços significativos em nossa literatura e sem dúvida serviu como forma de representar os nossos medos mais obscuros e mais íntimos, sem perder a sua famigerada maldade.

\section{REFERÊNCIAS}

ANJOS, Augusto dos (s/d). Eu/Outra poesia. São Paulo: Círculo do Livro.

ARINOS, Afonso (2006). "A esteireira". In: Contos. São Paulo: Martins Fontes. p.51-62.

AUERBACH, Nina (2009). "Foreword". In: SKAL, David J. Romancing The Vampire: From Past To Present. Atlanta: Whitman Publishing LLC. p.4-6.

AZEVEDO, Aluísio (1894). A mortalha de Alzira. Rio de Janeiro: Fauchon \& Cia.

BíBLIA SAGRADA (1992). Centro Bíblico Católico, Frei João José Pereira de Castro (Trad.). 86.ed. São Paulo: Editora Ave Maria.

BROWN, Donald F. (1945). “Azevedo's naturalist version of Gautier's La Morte Amoureuse". Hispanic Review. (13)3, 252-257.

CABRAL, Luciano (2017). "Medo e monstruosidades". In: FRANÇA, Júlio. (Org.). Poéticas do mal: a literatura do medo no Brasil (1840 - 1920). Rio de Janeiro: Bonecker. p.201-224. 
COHEN, Jeffrey Jerome (2000). "A cultura dos monstros: sete teses". In: SILVA, Tomaz Tadeu da. (Org.). Pedagogia dos monstros: os prazeres e os perigos da confusão de fronteiras. Belo Horizonte: Autêntica. p.23-60.

COLERIDGE, Samuel Taylor (2010). "Christabel”. In: COSTA, Bruno. (Org.). Contos clássicos de vampiro, Byron, Stoker e outros. Bruno Gambarotto (Trad.). São Paulo: Hedra. p.241-263.

CRULS, Gastão (1951). "Noites Brancas". In: Contos Reunidos. Rio de Janeiro: José Olympio. p.59-71.

FRANÇA, Júlio; SANTOS, Ana Paula Araujo dos (2018). "As artes e os atributos do mal". In: As Artes do Mal: Textos seminais. 1.ed. Rio de Janeiro: Bonecker. p.13-21. GAUTIER, Théophile (2010). "A morta amorosa”. In: COSTA, Bruno. (Org.). Contos clássicos de vampiro, Byron, Stoker e outros. Marta Chiarelli (Trad.). São Paulo: Hedra. p.123-161.

GROOM, Nick (2018). The Vampire; A New History. Great Britain Yale University Press, New Haven and London.

LECOUTEUX, Claude (2005). Histórias dos Vampiros: autópsia de um mito. Álvaro Lorencini (Trad.). São Paulo: Editora UNESP.

LE FANU, Sheridan (2010). Carmilla - A vampira de Karnstein. José Roberto O’Shea (Trad.). São Paulo: Hedra.

MENDES, Leonardo (2016). "Biblioteca do Solteirão: o livro pornográfico nas conexões Brasil-Europa no final do século XIX". In: ABREU, Márcia. (ed.). Romances em movimento: A circulação transatlântica dos impressos. Campinas: Ed. Unicamp.

SENA, Marina (2017). "Sombras no romance experimental: o decadentismo de Aluísio Azevedo". In: BARROS, Fernando Monteiro de; COLUCCI, Luciana; FRANÇA, Júlio; SILVA, Alexander Meireles da. (Orgs.) Estudos do Gótico. Rio de Janeiro: Dialogarts. p.99-109.

SILVA, Alexander Meireles da (2010). "Introdução". In: COSTA, Bruno. (Org.). Contos clássicos de vampiro, Byron, Stoker e outros. São Paulo: Hedra. p.9-41. PUNTER, David (1996). The Literature of Terror. 1. 2.ed. London: Longman. STOKER, Bram (2014). Drácula. José Francisco Botelho (Trad.). São Paulo: Penguin Classics/Companhia das Letras. 


\section{O FENÔMENO DO VAMPIRISMO: GIOSEPPE DAVANZATI E A INTRODUÇÃOO DO VAMPIRO NA EUROPA OCIDENTAL (1739-1774)}

Gabriel Elysio Maia Braga (UFPR)

Recebido em 15 mar 2019. Aprovado em 08 mai 2019.
Gabriel Elysio Maia Braga é Mestre em História pela Universidade Federal do Paraná (UFPR). Atualmente é aluno no curso de Doutorado do Programa de PósGraduação em História da UFPR e bolsista CAPES. Realiza pesquisas acerca do sobrenatural na História, em especial mortos-vivos, vampiros e possessões demoníacas. Atualmente realiza pesquisa sobre possessões e rituais de exorcismo na França do século XVII. Tem interesse nas áreas de História do Medo e História Cultural da Ciência. É apaixonado por filmes de horror e literatura de ficção-científica. Lattes: http://lattes.cnpq.br/6536733437871944. E-mail: gab. braga94@gmail.com.

Resumo: Os relatos sobre ataques de mortos-vivos nos Bálcãs popularizaram-se em finais do século XVII. A primeira explicação dada em um periódico relacionava os mortos mastigadores - não ainda chamados de vampiros - ao demoníaco. Alguns pensadores, porém, se propuseram a investigar o assunto a partir da Natureza. Entre eles, havia Gioseppe Davanzati, padre italiano de formação jesuíta autor da Dissertazione Sopra i Vampiri, redigida em 1739, porém publicada apenas em 1774. Entre estas datas, a obra circulou em forma manuscrita. Apesar de sua interessante teoria 
sobre a imaginação, o principal feito de Davanzati, mesmo que essa não fosse sua intenção, foi o de disseminar o termo vampiro pela Europa.

Palavras-chave: Vampiros; Gioseppe Davanzati; Imaginação.

Riassunto: I relati d'attacchi di morti-vivendi nei Balcani, furono divulgati nei fini dei XVII secolo. La prima spiegazione data in periodico relazionava i morti masticatori-non ancora chiamati vampiri-al demoniaco. Alcuni pensatori, tuttavia, decisero investigare I'assunto a partire della Natura. Tra loro, c'era Gioseppe Davanzati, prete italiano di formazione gesuitica autore della Dissertazione Sopra i Vampiri, scritta nel 1739, però pubblicata solo nel 1774 . Nel frattempo, l'opera si diffuse nella sua forma manoscritta. Nonostante la sua interessante teoria sull'immaginazione, la principale azione di Davanzati, tuttavia non fosse la sua intenzione, fu la diffusione del termino vampiro nell'Europa.

Parole chiave: Vampiri; Gioseppe Davanzati; Immaginazione.

A imagem do vampiro recebeu uma caracterização definitiva em Drácula (1897) do escritor irlandês Bram Stoker. Sua pesquisa para o desenvolvimento da história e do personagem principal durou sete anos (ARGEL; MOURA NETO, 2008, p.34). O conde vampiro é um verdadeiro aglomerado de lendas euro-orientais sobre mortosvivos e aparições de mortos. A característica mais assustadora da lenda, o sugar do sangue alheio, ganhou notoriedade nos relatos oficiais de mortos-vivos apenas na última década do século XVII, através de periódicos euro-ocidentais que relatavam estes ataques ocorridos nos Bálcãs.

Em 1693, o periódico francês Le Mercure Galant falou sobre cadáveres possuídos por demônios. Estes últimos deixariam 
as tumbas na forma espiritual e retirariam sangue de vítimas, geralmente parentes próximos. O sangue ficaria todo armazenado no corpo dentro do caixão. Dessa forma, estaria explicada a grande quantidade de sangue encontrada saindo dos orifícios do cadáver (BRAGA, 2018, p.122). A única forma de impedir as mortes dos parentes do falecido era a destruição do corpo, que seguia um ritual bastante particular. Primeiro, uma estaca era atravessada no peito no cadáver. Seguiam-se então a decapitação e a incineração do corpo. Algumas variações incluíam também a retirada o coração e/ou o ato de jogar as cinzas em um rio.

A opinião majoritária da República das Letras durante a modernidade era a de que todos os relatos seriam falsos, produtos de superstições e crendices. Alguns autores modernos, contudo, não satisfeitos com a resposta rápida e simples, ficaram intrigados com o tema e resolveram investiga-lo mais a fundo. Destaco três principais, o filósofo alemão Michaël Ranft (1700-1774), autor de De Masticatione Mortuorum in Tumulis $(1728)^{1}$; o padre italiano Gioseppe Davanzati (1665-1755), autor da Dissertazione Sopra $i$ Vampiri (1774); e o monge beneditino francês, dom Augustin Calmet (1672-1757), autor do Traité sur les apparitions des esprits et sur les vampires ou les revenans de Hongrie, Moravie, etc. (1751). ${ }^{2}$

Tanto a dissertação de Ranft quanto o tratado de Calmet foram explorados em minha dissertação de mestrado, O Natural e o Sobrenatural na Modernidade: a polêmica erudita sobre os mortos-vivos (1659-1751) (2018). Em relação a Davanzati, contudo, havia apenas conseguido acesso indireto à sua dissertação. Uma

1 Versão ampliada de sua dissertação, Dissertatio historico-critica de masticatione mortuorum in tumulis, defendida em 1725.

2 Terceira edição, revisada e ampliada, de sua dissertação, publicada em 1746. 
vez podendo analisá-la, decidi redigir esse artigo para apresentar a obra que popularizou o termo vampiro na Europa ocidental.

Ranft foi o primeiro a publicar uma obra de peso sobre o tema e em momento algum utiliza a célebre nomenclatura. O filósofo alemão chama tais criaturas de mortos mastigadores, devido ao relatado hábito de mastigar as próprias vestes e até mesmo partes de seus corpos. Não há referência, em sua dissertação, à ação de sugar sangue. Sua obra é muito importante na história das investigações sobre mortos-vivos, pois nela buscou encontrar uma resposta que não considerasse nem a ação divina, nem a demoníaca. Ranft defendeu que "todos os fenômenos poderiam ser explicados a partir das potencialidades da Natureza" (BRAGA, 2018, p.141).

Calmet dedicou uma obra de quase mil páginas ao assunto. Seu objetivo principal foi o de "desenganar o mundo da opinião que há sobre as Aparições [détromper le monde de l'opinion qu'il a sur les Apparitions]" (CALMET, 1751a, p.IV). O monge considerava que as análises feitas em periódicos haviam pecado por falta de método. Grande admirador de Descartes e Newton, Calmet defendia que os relatos de vampiros não deveriam ser desconsiderados, mas sim postos à prova. Sua metodologia foi a de considerar todos os relatos como reais de forma literal. Assim, pode construir uma argumentação para rebater as narrativas em seus mais particulares detalhes.

A obra de Davanzati foi redigida entre as de Ranft e Calmet. Sua publicação, contudo, deu-se apenas após a morte do autor. De acordo com as informações que aparecem na introdução anônima, a obra já estaria pronta em 1739, tendo sido lida e aprovada pelo papa Bento XIV em 12 de janeiro de 1743. Alguns autores afirmam que há uma versão da dissertação publicada em 1744, porém não 
há nenhum indício de tal impressão. Sabe-se, contudo, pela pesquisa de Francesco Ceglia (2011), que o acadêmico alemão Pieter Burman (1668-1741) teceu, através de uma carta, elogios à obra de Davanzati, o que comprova que a Dissertazione circulou em forma manuscrita, antes mesmo da aprovação papal. (CEGLIA, 2011, p.488).

Quando se faz uma pesquisa sobre as origens da lenda dos vampiros na internet é comum encontrar informações que a relacionem com os enterros prematuros, ou seja, pessoas que por algum motivo, catalepsia, por exemplo, haviam sido sepultadas por engano, gerando um grande susto nos demais quando se mostravam vivas, ou então causando espanto quando o caixão era aberto e sua tampa estava arranhada na parte interna.

Tal explicação, entretanto, é insuficiente e desconsidera o contexto de finais do século XVII até meados do século XVIII, quando a lenda do vampiro se espalhou pela Europa. Os enterros prematuros eram largamente conhecidos. Jean Delumeau (2009) destacou que desde o século XVI é possível encontrar nos testamentos a exigência de um período - algumas vezes longo - de velório. O que indicaria o medo de um eventual enterro prematuro (DELUMEAU, 2009, p.134). Nesse mesmo período os médicos já se preocupavam com métodos para detectar a morte aparente (ARIÈS, 2014, p.527). O próprio Calmet cita em seu trabalho a catalepsia como uma das muitas possíveis explicações para o fenômeno, porém não a considera a mais próxima da verdade.

Foi a partir dos relatos publicados na Europa ocidental desde finais do seiscentos que foi criada a imagem do vampiro literário. A preferência pelo período noturno, a estaca e o sugar do sangue são 
elementos característicos. A aversão a símbolos católicos parece ser da criatividade de Stoker, pois não há menção alguma à utilização de água benta ou alho ${ }^{3}$ para impedir os ataques de vampiros. A profilaxia recomendada envolvia se ungir no sangue do vampiro, ou então comer um pão "com o sangue que se recolhe desses tipos de Cadáveres [avec le sang qu'on recueille de ces sortes de Cadavres]" (ARTICLE, 1693, p.66).

\section{OS RELATOS DE ATAQUES DE VAMPIROS}

O primeiro capítulo da dissertação, intitulado Storia de' Vampiri, e suoi effeti [História dos Vampiros e seus efeitos], concede um panorama geral do tenebroso fenômeno. O padre reportou que soube dos relatos através do cardeal Schrattembac, arcebismo de Olmitz: ${ }^{4}$

A doença ou a chacina dos Vampiros era muito frequente na Província da Morávia, sua Diocese; e que embora tivessem adotado os truques habituais para frear o mal; todavia com muito descontentamento cada vez mais se expandia com morte e extermínio daquela pobre gente.

[il morbo o la strage de' Vampiri era molto dilatata nella Provincia della Moravia sua Diocesi; e che quantunque avessero adoperato i soliti espedienti per frenare il malore; tuttavia con molto loro dispiacimento vieppiù si dilatava con morte ed esterminio di quella povera gente]. (DAVANZATI, 1774, p.1)

Além das mortes, havia o pânico gerado nas vilas atingidas por tal mal, o que ocasionava no êxodo da população. Essa constatação

30 alho era comumente utilizado como repelente de maus espíritos, não necessariamente os vampiros.

4 Uma corruptela de Olmütz, atual cidade de Olomouc, na República Tcheca.

5 Todas as traduções feitas nesse artigo são de minha autoria. 
aparece até mesmo nos relatos oficias, como por exemplo, o caso do suposto vampiro Peter Plogojowitz, na vila de Kisilova, na atual Sérvia. O relator imperial declarou que caso não fosse atendido o pedido de exumação do cadáver de Plogojowitz, os camponeses abandonariam a vila, e assim o tinham ameaçado (BRAGA, 2015, p.48).

Davanzati, ainda no primeiro capítulo, buscou definir o que seriam as tais criaturas que atormentavam os Bálcãs:

os referidos Vampiros outro não eram, que alguns homens mortos há alguns dias, os quais já sepultos e enterrados apareciam de novo na mesma forma, e nas mesmas vestes e aparências de quando eram vivos, e se faziam ver a seus parentes, e amigos de dia, e de noite, verdadeiramente passando nas suas casas, conversando, falando, e comendo com eles: e às vezes colocando-se à cama. Convidavam aqueles a repousar igualmente com eles.

[i suddetti Vampiri altro non erano, che alcuni uomini morti da alcuni giorni prima, i quali già sepolti e sotterrati comparivano di nuovo nella stessa forma, e negli stessi abiti, e portamenti di quando erano vivi, e si facevano vedere da' loro parenti, ed amici di giorno, e di notte, portandosi francamente nelle lor case, conversando, parlando, e mangiando con esso loro: e talvolta mettendosi a letto. Invitavano quelli a riposarsi parimente con esso loro]. (1774, p.2)

Neste trecho há um ponto que distancia o vampiro folclórico do vampiro literário, o horário de sua aparição. Davanzati destacou que os mortos-vivos poderiam aparecer inclusive de dia. O fenômeno também se destacava pela frequência das aparições. Elas ocorriam de tal forma que havia um crescente na interação do vampiro com a pessoa visitada, "até o ponto em que os referidos vampiros 
Ihes sugando todo o sangue [fino a tanto che i suddetti Vampiri succhiandosi tutto il sangue]" (DAVANZATI, 1774, p.2), engordavam até que estivessem satisfeitos.

Suas vítimas pereciam em poucos dias, tamanha era a avidez dos vampiros por sangue humano. Além disso, os que faleciam em decorrência dos ataques transformavam-se em vampiros, elevando o problema a proporções epidêmicas. A solução apresentada pelo cardeal a Davanzati era a de procurar o tribunal secular e apresentar o nome do suposto vampiro. A partir das informações colhidas pelos agentes da lei era possível que o tribunal autorizasse a população a seguir os seguintes passos:

que (...) abra o sepulcro, e com um sabre ou larga espada a vista de todos os espectadores corte a cabeça do Vampiro, e depois com uma lança lhe abra o peito, e transpasse com ferro de um lado ao outro o coração do Vampiro arrancando-Ihe do seio, e então volte a fechar a tumba.

[che (...) apra il sepolcro, e con una sciabla o larga spada a vista di tutto il popolo spettatore recida al Vampiro il capo, e dopo con una lancia gli apra il petto, e trapassi col ferro da parte a parte il cuore del Vampiro strappandoglielo dal seno, e poi ritorni di nuovo a chiudere l'avello]. (DAVANZATI, 1774, p.3)

Não se deve pensar que tal processo judicial era desprovido de formalidades. A investigação se baseava em alguns critérios. Mesmo com a autorização para a exumação não eram garantidos os outros passos. Para que o ato de extermínio do vampiro prosseguisse era necessário constatar se o exumado era realmente um morto-vivo. O que Davanzati relatou é também encontrado em relatos oficiais e outras obras sobre os vampiros dos Bálcãs. Para ser considerado 
um sugador de sangue, o cadáver deveria apresentar alguns sinais, "como o sangue ao redor da boca, dos olhos, das narinas e dos ouvidos; o bom estado de conservação; a aparência avermelhada das bochechas; e, por vezes, os olhos abertos" (BRAGA, 2018, p.27).

Tais relatos, afirmou o autor, o teriam feito gargalhar, caso não tivessem sido apresentados pelo cardeal Schrattembac. Davanzati declarou que apenas deu atenção aos relatos fantásticos devido à credibilidade do narrador. Apesar disso, não havia como considerar os relatos verdadeiros sem antes um exame de circunstâncias e um período de reflexão. O padre desejava agregar à narrativa do cardeal outros relatos sobre aparições de mortos-vivos, porém, ficou algum tempo sem ouvir nada sobre o assunto.

A temática dos vampiros apareceu para Davanzati novamente através de periódicos impressos em Viena, cujos conteúdos haviam sido replicados até serem publicados na Holanda em 1736 (DAVANZATI, 1774, p.7). O relato que o autor reproduziu é de um caso ocorrido em Kisilova, na Sérvia, onde um senhor de 72 anos, três dias após ser enterrado, apareceu na casa de seu filho, pedindo por comida. Após a segunda visita do falecido, o filho foi encontrado morto em sua cama. Nesse mesmo dia, mais cinco ou seis pessoas teriam sido acometidas por um mal súbito e faleceram. (1774, p.8).

Houve uma investigação por parte das autoridades, na qual ocorreu a exumação dos que haviam morrido. Todos foram encontrados, segundo o relato, com os olhos abertos, pele avermelhada e "com uma respiração natural [con una respirazione naturale]" (p.9), sinais que indicavam que o morto seria um vampiro. Foi designado um executor que atravessou uma estaca 
no coração de cada cadáver e, em seguida, os incinerou. Destaco a parte final do relato, em que o autor afirma não ser possível "recusar crer verídico um fato juridicamente atestado por pessoas de crédito [ricusare di creder vero un fatto giuridicamente attestato da persone di probità]" (p.9).

É interessante ressaltar que Kisilova foi palco de pelo menos mais um caso em que um morto-vivo foi o protagonista. No ano de 1725, veio à tona o episódio de Peter Plogojowitz. Na época, a região da Sérvia em que Kisilova se encontrava estava sob domínio austríaco. Os tratados de Carlowitz (1699) e de Passarowitz (1718) cedeu à Áustria dos Habsburgos "com o primeiro, da maior parte da Hungria e, com o segundo, do norte da Sérvia, norte da Bósnia e da Valáquia" (BRAGA, 2015, p.10). Foi durante a ocupação militar habsburga que foram produzidos os mais conhecidos relatos de ataques de vampiros na Europa oriental.

O caso de Plogojowitz segue uma estrutura bastante similar àquela do relatado por Davanzati. Após 10 semanas passadas de sua morte, o falecido teria levantado de seu túmulo e interagido com os habitantes da vila. Diversas pessoas relataram que Plojogowitz teria tentado estrangulá-las (BRAGA, 2018, p.107). Os visitados, assim como no outro caso, também sofreram de uma rápida doença e morreram. O relato produzido acerca do processo que se seguiu é bastante interessante. A população recorreu ao provedor imperial, para que este tomasse uma decisão. A sugestão do patriarca - ou do papa local, como é chamado no relato - foi de que se prosseguisse com a exumação e destruição do cadáver.

No relato oficial é possível perceber a cuidadosa escolha de palavras por parte do provedor imperial. A utilização dos adjetivos, 
defendo, tinha como objetivo "sustentar o pensamento de que a população local seria exaltada e tomaria decisões precipitadas" (BRAGA, 1028, p.108). O autor do relato ressaltou o desespero e a agressividade da população, que inclusive o teria ameaçado, e parece se desculpar pelo que poderia ser considerado uma barbárie pela administração imperial, ou seja, a decapitação e incineração do cadáver.

A reação de Davanzati ao relato foi resumida em uma frase: "Graças ao Céu não somos tão crédulos [Grazie al Cielo non siamo sì creduli]" (DAVANZATI, 1774, p.9). Entretanto, o relato não poderia ser imediatamente recusado devido à sua proveniência. Apesar de considerá-lo crendice, o padre italiano pensava ser necessária uma maior atenção para as possíveis explicações do fenômeno.

Um outro caso citado ocorreu em uma região da Hungria chamada de Oppidum Heidonum, que ficava além do rio Tisza um afluente do Danúbio - que atravessa terras da Transilvânia, localidade que no século XIX ganharia a fama de ser a "terra dos vampiros". De acordo com Davanzati, essa região acredita na existência de criaturas chamadas de vampiros, que seriam mortosvivos que sugavam o sangue de pessoas vivas, levando-as à morte (DAVANZATI, 1774, p.9). O relato utilizado como exemplo da crença é o de Arnod Paole, que se tornou célebre na Europa ocidental graças ao relato Visum et Repertum, produzido em 1732 por uma comissão de médicos e militares enviada à região pelo império Habsburgo.

Paole havia morrido de uma queda de sua carroça. Contudo, 30 dias após a sua morte, quatro habitantes de sua vila, Medvegia, ${ }^{6}$ relataram aparições do falecido. Estas, somadas ao que Paole 6 Também escrita como Medreïga e Medraiga. 
contava em vida - que havia sido perseguido por um vampiro turco quando viajou para a Sérvia turca (BRAGA, 2018, p.109) apontavam para o vampirismo. Prosseguiu-se com a exumação do corpo do suposto vampiro. Dentro do caixão, foi encontrado "um cadáver praticamente intacto do qual brotava sangue a partir dos olhos, boca, nariz e orelhas" (BRAGA, 2018, p.109).

As medidas tomadas quando da constatação da situação do corpo foram as que se tornaram clássicas na literatura de horror: uma estaca atravessou o coração do cadáver, após isso ele foi decapitado e, por último, incinerado. Importante ressaltar que, de acordo com o relato, ao penetrar a estaca "Paole teria emitido um grito audível e sangrado copiosamente" (BRAGA, 2018, p.109-110), informação que apenas reforçou a narrativa de que o morto era um sugador de sangue. Somado a isso, foi constatado que o cadáver apresentava aparência saudável, com barba e cabelos crescidos, e coloração vermelha, sinais que indicariam vampirismo.

As medidas tomadas contra o cadáver de Paole, entretanto, "foram inúteis [sono state inutili]" (DAVANZATI, 1774, p.11), pois os habitantes continuaram relatando ataques noturnos. Tendo em consideração os ataques anteriores, "concluiu-se, portanto, que as quatro pessoas que haviam morrido após relatar a visita do mortovivo, deveriam ter, por sua vez, se tornado vampiros também" (BRAGA, 2018, p.110). Providenciou-se o extermínio de mais quatro vampiros, cumprindo com os passos da exumação, da estaca, da decapitação e da incineração do cadáver.

Ainda assim, os ataques não cessaram. Descobriu-se que Paole havia sugado sangue de um gado, cuja carne fora consumida por 
17 pessoas. Seguiu-se, então, uma série de exumações que foram relatadas pelos oficiais austríacos. Visum et Repertum teve uma grande parcela de responsabilidade na disseminação da lenda do vampiro na Europa ocidental e consiste no maior caso de vampirismo relatado.

Davanzati, ao se referir ao vampiro Arnod Paole, utilizou o termo Arquivampiro [Arcivampiro], sem, contudo, defini-lo. Devido aos acontecimentos do caso, posso sugerir que tal termo denominaria o vampiro principal, ou seja, aquele que iniciou a cadeia de contaminação, de propagação do mal. Fora Paole o responsável direto pelos outros 4 vampiros cujos corpos foram exumados em seguida; e o responsável indireto por outros 17 mortos suspeitos de terem se transformado em criaturas sugadoras de sangue.

Após apresentar, no primeiro capítulo, as principais características da lenda do vampiro, Davanzati buscou uma explicação para o fenômeno. A primeira procura foi de caráter histórico. Para o autor, dado que as leis naturais seriam invariáveis, os vampiros deveriam existir em tempos passados. Assim sendo, deveria haver relatos mais antigos de sua existência (DAVANZATI, 1774, p.14). Para a surpresa do padre, ele encontrou relatos de mortos-vivos até mesmo em sua biblioteca pessoal. Heródoto, Tito Lívio, Plutarco e Valério Máximo foram citados entre os autores que haviam relatado aparições de mortos (1774, p.15).

Os vampiros, segundo as pesquisas de Davanzati, possuiriam particularidades geográficas. Suas aparições se davam em locais distintos e remotos em termos de clima, religião e costumes ( $p$. p.14), sem especificar o que significariam tais adjetivos. $O$ autor 
ressaltou, contudo, que o termo vampiro era restrito à Alemanha e à Hungria. Conclusão que negligenciou o ineditismo do termo e mesmo a novidade que os relatos apresentavam: o ato de sugar sangue. Dom Augustin Calmet, diferente do padre italiano, ressaltou o caráter de novidade das aparições de vampiros (BRAGA, 2018, p.204). Em sua opinião, o ato de sugar sangue - que caracteriza os vampiros até hoje na ficção - era algo inédito no que dizia respeito a aparições de mortos.

A diferença entre os dois religiosos que escreveram sobre os vampiros consiste, justamente, no que consideram um vampiro. Calmet, em seu tratado, classificou os vampiros como uma espécie de Revenans, ${ }^{7}$ que possuía uma particularidade característica: a ação de sugar sangue. Já Davanzati, parece não dar grande importância ao sugar do sangue, mas sim ao fato de os vampiros serem definidos como mortos-vivos. Assim, sua busca, apesar de citar diversos termos que denominam diferentes criaturas, não se preocupou em defini-las, nem em diferenciá-las.

Davanzati aglutinou no mesmo grupo espectros, fantasmas, larvas, lêmures, dentre outras criaturas. Espectros e fantasmas referem-se a aparições de mortos, que podem tanto ser assombrações quanto portadores de notícias. Larvas e lêmures são entidades da Roma antiga, os primeiros eram os que causavam malefícios, os segundos eram os mortos prematuros. Estas duas criaturas andavam entre os vivos, os atormentando, podendo ser apaziguadas através de rituais (BUSTAMANTE, 2011, p.4-5).

De modo geral, as aparições que o padre italiano utiliza para justificar a historicidade dos vampiros, foram consideradas por 7 Grafado dessa forma, sem a letra " $t$ ". 
Calmet (1751) como aparições de fantasmas. Enquanto este buscou dar mais ênfase na novidade da criatura presente em relatos como o Visum et Repertum (1732), Davanzati buscou a permanência dos relatos das aparições de mortos ao longo dos séculos. Para o monge francês, a lenda do vampiro, apesar de ser incluída no campo maior das aparições de mortos, possui um elemento de ruptura, uma característica peculiar. Por outro lado, o padre italiano optou por enfatizar a permanência de tais lendas.

\section{AS EXPLICAÇÕES PARA O FENÔMENO}

Do mesmo modo que buscou na história relatos de vampiros do passado, Davanzati também explorou as possíveis explicações dadas em diferentes períodos históricos. Nos capítulos III e IV de sua dissertação, perguntou-se se as aparições de vampiro poderiam ser explicadas por sistemas filosóficos da antiguidade e da modernidade. Davanzati analisou três sistemas antigos e cinco modernos.

Como primeiro exemplo, escolheu o filósofo Pitágoras, que teria ido ao Egito aprender sobre a metempsicose, "ou seja, transmigração da alma humana nos outros corpos depois de sua morte [o sia, trasmigrazione dell'anime umane negli altri corpi dopo la di loro morte]" (DAVANZATI, 1774, p.29).

Através da metempsicose, explicou Davanzati, a alma de um morto poderia passar para um corpo muito parecido, o que daria a ilusão de que ele havia retornado (p.31). O corpo é importante para a explicação, pois se o morto aparecesse apenas em espírito, não seriam possíveis as interações táteis que apareciam nos relatos. Habitando outro corpo, o espírito do morto poderia se alimentar e deitar-se na cama com seus parentes, tal como apresentavam as narrativas. 
Para Davanzati, contudo, a explicação por via da metempsicose, embora devesse ser considerada, não seria satisfatória. A grande dúvida seria o que aconteceria de dia com o outro corpo habitado pelo espírito do morto. O padre se questiona o porquê ele seria visto apenas à noite, algo que não teria explicação apenas pela via da metempsicose. Outro ponto importante é que, depois da destruição do cadáver, este corpo também parava de ser visto.

Outra possível explicação foi buscada em Laércio, que compartilhava de uma doutrina que separava o homem em dois, corpo e alma. Entretanto, diferente da divisão entre corpo material e alma imaterial - e imortal - o filósofo defendia a materialidade e a mortalidade da alma. A diferença entre corpo e alma estava na matéria formadora. Enquanto o primeiro consistiria em uma matéria sólida e densa, a alma seria composta por uma matéria fluída, ágil e leve. De acordo com essa doutrina, com a morte e a separação entre corpo e alma, o primeiro ficava enterrado, enquanto a segunda, devido à fluidez, permanecia incorrupta, andando ao redor de seu corpo e o guardando (1774, p.34).

Esta explicação, porém, também não era considerada verdadeira pelo autor. Dada a separação entre corpo e alma, o sistema falhava em explicar o motivo do fim das aparições após o cadáver ser decapitado. Outro ponto era que, sendo cristão, Davanzati era contra a materialidade da alma. a imortalidade da alma era "clara como o Sol [chiara come il Sole]" (p.37). Assim sendo, a doutrina apresentada somente poderia ser falsa.

Uma terceira possível explicação poderia ser encontrada na doutrina cirenaica, de Diógenes Laércio, a qual dividia o homem em 
três partes: a alma, espiritual e imortal; o corpo, que desaparece após a morte; e uma última substância, também chama de segunda alma, de natureza média entre o corporal e o espiritual que existiria para unir corpo e alma (p.37). Esta segunda alma permaneceria, após a morte, próxima do corpo, a fim de protegê-lo e realiza este trabalho até sua total dissolução.

A doutrina da segunda alma, na visão do padre, não era contraditória em relação à doutrina católica. No caso das aparições de vampiros, portanto, seria esta segunda alma a protagonista, pois ela manteria alguns hábitos do corpo. Assim sendo, esta substância intermediária poderia se alimentar e tocar os vivos. Esta explicação também abarcaria o sumiço das aparições após a destruição do cadáver - pois, nesse caso, a segunda alma não teria mais um corpo para guardar.

O problema desta doutrina, na visão de Davanzati, é que lhe faltavam fundamentos de razão. A alma espiritual já supriria tudo o que a segunda supostamente deveria fazer, assim sendo, a segunda alma seria uma duplicata. Ora, isso iria contra a Lei da Parcimônia, citada por Davanzati, que diz que as entidades não deveriam ser multiplicadas sem necessidade. ${ }^{8}$ Aqui, o autor mesclou as duas frases do princípio de Occam para defender o caráter reduzido dos fenômenos naturais. No sentido de que não poderiam existir elementos em excesso, tal como a segunda alma, que apenas repetiria efeitos da alma espiritual, não possuindo, portanto, razão de existir.

Após explorar três sistemas antigos, o autor se deteve na análise de cinco possíveis explicações filosóficas modernas para o fenômeno 8 "non sunt multiplicanda entia sine necessitate". (p.40). 
do vampirismo. Primeiramente, Davanzati cita a possibilidade de existência de criaturas que não podem ser classificadas como corporais nem como espirituais. Como exemplo, citou os faunos, que habitariam os bosques (DAVANZATI, 1774, p.42). 0 autor ressalta que relatos sobre esse tipo de criatura haviam destacado sua habilidade de mudar de aparência.

Davanzati também citou o grande número de espécies de animais e mesmo de tipos de anjos, para mostrar que o corporal e o espiritual não eram conceitos fixos, mas sim que havia níveis de corporeidade e de espiritualidade. Assim sendo, os vampiros poderiam ter um lugar nessa escala, como "alguma substância média entre os espíritos puros e os homens [alcune sostanze medie fra i puri spiriti e gli uomini]" (1774, p.46). Para confrontar este sistema, o autor diferencia possibilidade de realidade. Os relatos sobre os faunos, por exemplo, haviam sido feitos por pessoas "ignorantes e de servil condição [ignoranti e di servile condizioni]" (1774, p.49), às quais não se poderia destinar um voto de confiança. A fim de desacreditar tais relatos, o autor cita a existência de babuínos e orangotangos, que poderiam ser confundidos com criaturas semi-humanas.

Outro ponto que, a partir dessa doutrina, ficaria explicado seria a similaridade entre a aparência do vampiro e do falecido. Ainda que se defendesse que tais criaturas poderiam modificar sua aparência, o padre questiona como seria possível explicar que elas desapareciam após a decapitação e incineração do cadáver que se cria morto-vivo. Para ele, não havia relação alguma que ligasse o defunto à suposta criatura - ou demônio - que seria o vampiro (1774, p.50-51). 
A crença de que a alma rodeia o corpo até sua total putrefação também aparece em Plutarco. Porém, mesmo que assim fosse, Davanzati reforça que a alma não possui substâncias matérias, portanto, não poderia manter a aparência que o corpo possuíra em vida (1774, p.52). A natureza da alma também foi questão essencial para Calmet. Uma das grandes questões do primeiro tomo do tratado do beneditino era se a alma seria puramente espiritual ou se estaria dotada de um corpo invisível, de substância parecida com o $\operatorname{ar}($ CALMET, 1751a, p.469). Essa questão da corporeidade da alma é vital para as investigações de vampiros. O que havia consternado Calmet era o fato de que, mesmo com a aparição do morto, o túmulo permanecia imaculado. Logo, o cadáver não poderia ter deixado seu caixão e cavado seu caminho até a superfície.

O segundo sistema citado é o de Tommaso Campanella (15681639), teólogo dominicano que defendia, de acordo com o autor, que o ambiente aéreo seria pleno de diferentes espécies "ou espectros de nós mesmos [o spettri di noi stessi]" (DAVANZATI, 1774, p.52). Neste ambiente, os homens permaneceriam, mesmo após a morte. Davanzati trata essa hipótese como um delírio. O grande problema era explicar o motivo de apenas algumas pessoas verem esses espectros já que o ambiente aéreo seria comum a todos.

O terceiro filósofo moderno citado foi tratado apenas pelo nome Gio. ${ }^{9}$ Ele alegava que, após a morte, as almas conservariam os membros e a aparência do corpo físico, incluindo aqui ossos e carne. Tal pensamento é para o padre italiano uma loucura. Em primeiro lugar porque se a alma fosse assim, todos poderiam vê-la. 
Em segundo, atenta à fé cristã, pois se a alma se separa do corpo e mantém carne e ossos, não seria necessária a ressureição no final dos tempos, além de que, a ressureição de Cristo teria sido sem propósito. "Loucura, loucura, podre disparate [Pazzia, pazzia, sproposito marcio]" (1774, p.54), declarou o autor.

Paracelso foi o quarto citado entre os autores modernos. Este alquimista geralmente aparece em produções que investigam a realidade - ou falsidade - dos mortos-vivos. Para ele, a morte só era absoluta após a total decomposição do corpo, até esse momento, - cadáver permaneceria em uma espécie de vida vegetativa. Consequentemente, também defendeu "o poder de influência da imaginação mesmo após a morte do indivíduo" (BRAGA, 2018, p.172). Ou seja, os mortos ainda teriam um poder de influência sobre os vivos, mesmo que sem intenção. ${ }^{10}$

Por fim, como quinta e última opinião moderna, citou os filósofos Gerard Feltman, Giovan Marco de Marco e Fortunio Liceto, autores de trabalhos sobre cadáveres e a morte. Estes autores compartilhavam de uma opinião similar à de Paracelso. Para eles, restaria uma alma sensitiva no corpo, que se ocuparia das funções vegetativas, tais como o crescimento de cabelos e barba e mesmo alguns movimentos corporais (DAVANZATI, 1774, p.56). Isso seria mais evidente nos que haviam falecido de morte violenta, pois teriam uma "inclinação para a vingança [inclinazione alla vendetta]" (1774, p.56).

A questão das mortes violentas é muito presente em investigações sobre o vampirismo. Calmet, por exemplo, cita que 
com esse tipo de morte o sangue do cadáver entraria em estado de ebulição, permitindo uma maior mobilidade corporal, "doenças agudas, alguns venenos, alguns tipos de peste, afogamento" (BRAGA, 2018, p.237), são outros motivos que levavam à ebulição sanguínea. Dessa forma, estaria explicada a não rigidez dos cadáveres que eram considerados vampiros. Apesar de não ter citado a ebulição sanguínea, Davanzati se utilizou de um pensamento que faz referência à morte violenta como um fator que poderia levar alguém a se transformar em um morto-vivo.

O padre italiano contesta a opinião da vida vegetativa, pois ela dependia da existência de duas almas, o que seria "contra todas as razões, e particularmente aos sentimentos sacrossantos da Santa Madre Igreja [contro ad ogni ragione, e particolarmente ai sentimenti sacrosanti della S. Madre Chiesa]" (DAVANZATI, 1774, p.56). Outro ponto da argumentação do autor é que, se tal proposição fosse uma lei da Natureza, todas as vítimas de mortes violentas deveriam se mexer em seus túmulos. Como visto nos relatos transcritos por Davanzati, havia uma particularidade geográfica, a qual não deveria sobrepor-se a leis naturais.

\section{UM FILÓSOFO MEZZO PIRRONISTA}

Após expor as opiniões acima, Davanzati se dedicou à "opinião de um filósofo meio pirronista sobre a aparição dos vampiros [opinione d'un filosofo mezzo pirronista sopra l'aparizione de'vampiri]" (DAVANZATI, 1774, p.59), título do quinto capítulo. O autor não o nomeou, apenas o definiu como "em grande parte cético [in buona parte Scettico]" (1774, p.59). Creio que seja uma forma caricaturada de o padre referir-se a céticos radicais. O tal 
filósofo defendia que a temática dos vampiros era uma inverdade, fruto de ilusões e credulidade, "efeitos de Baco ${ }^{11}$ [effetti di Bacco]" (1774, p.59) que afetariam o cérebro. Desse modo, poder-se-iam explicar a visão de pessoas que haviam morrido, por exemplo.

Contudo, o ceticismo não seria uma resposta completamente adequada, pelo menos não sozinho. Davanzati afirmou que devido aos testemunhos serem de pessoas confiáveis, não seria possível tratá-los com absoluto desprezo. Opinião que é bastante parecida com a de Calmet. 0 monge beneditino, apesar de não acreditar nos vampiros, redigiu um tratado para tentar explicar os testemunhos, pois, de acordo com ele, não seria possível negá-los sem antes, a realização de um exame de circunstâncias. De fato,

testemunhas de crédito traziam um estatuto de verdade para os relatos. Essa verdade, contudo, não era tida como absoluta. Mesmo sendo reais, o que era narrado deveria ser posto à prova para se entender se tais criaturas realmente existiam ou se as narrativas eram fruto de erros, ou então de problemas relacionados à imaginação. (BRAGA, 2018, p.20)

As conjecturas do filósofo mezzo pirronista de Davanzati continuam. Os tais vampiros poderiam não estar verdadeiramente mortos, mas sim serem frutos de enterros prematuros, ou seja, pessoas que haviam sido erroneamente sepultadas, mas que não estariam mortas de verdade. ${ }^{12}$ A confusão causada pelo retorno do suposto morto à sua própria casa poderia afetar um "povo um pouco crédulo [popolo un poco credulo]" (DAVANZATI, 1774, p.60).

11 Uma alusão ao álcool.

12 Apesar de já se ter o conhecimento sobre o estado catatônico na época, Davanzati não o cita como uma possibilidade. 
A parte do cemitério também poderia ser explicada pelo efeito que o medo causaria no povo. Ao procurar o vampiro em sepulturas não muito bem identificadas, o exumado poderia ser qualquer cadáver. Enquanto isso, aquele que havia sido considerado vampiro fugia de medo da fúria popular (1774, p.60-61).

O mesmo filósofo pirronista considerava bárbara a maneira como eram tratados os cadáveres. Exumação, empalamento e incineração eram métodos abomináveis, frutos de superstições. Uma verdadeira ofensa às leis humanas e divinas (1774, p.60-61). O autor desafia o anônimo cético, se ele estivesse tão certo de sua opinião, a ir até as localidades de onde provinham os relatos e desenganar o povo. Nesse ponto Davanzati fez uma interessante crítica aos pirronistas, que teriam "glória de negar tudo, e de nada afirmar por verdade [gloria di negar tutto, e di nulla affermare per vero]" $(1774$, p.62).

Não era pelo motivo de parecer extravagante que o fenômeno do vampirismo poderia ser considerado inverídico. Era necessário confrontar os casos com a razão, a fim de chegar a uma conclusão (1774, p.63). O padre citou Copérnico como autor de uma teoria, a rotação da Terra em torno do Sol, que a princípio parecia extravagante e sem sentido. O astrônomo fora perseguido pela Inquisição. Contudo, com os modernos cálculo matemáticos e astronômicos, afirmou Davanzati, sabia-se que Copérnico estava certo. Razão e experiência, de acordo com o autor, haviam sido as responsáveis pelas comprovações das descobertas de Galileu, que a princípio também haviam sido tratadas como extravagantes.

Esta opinião do autor estava de acordo com os parâmetros estabelecidos pela chamada Revolução Científica do século XVII, 
que buscou se distanciar das formas de produção vigentes nos séculos anteriores e estabelecer uma visão positiva acerca do futuro. O autor critica a Inquisição pela falta de investigação em suas condenações. Tal opinião foi bastante comum no século XVII. O médico holandês Johann Weyer (1515 - 1588), fez inúmeras críticas ao Santo Ofício, pois considerava que os inquisidores concediam um poder ao Diabo que ele não possuía. Em outras palavras, para Weyer, eles superestimavam as ações demoníacas. De um modo geral, a partir dos séculos XVII e XVIII, "o ponto principal das críticas à Inquisição era a forma como os processos ocorriam, em especial o uso da tortura" (BRAGA, 2018, p.85).

\section{ENTRE O SOBRENATURAL E A NATUREZA}

Uma questão importante para a modernidade foi acerca do estabelecimento dos limites entre o natural e o sobrenatural. Diversas foram as produções que buscaram compreender os segredos da natureza, ou como denominava Michaël Ranft, os seus poderes ocultos [pouvoirs cachés]. A dissertação de Gioseppe Davanzati não foge desse objetivo. Uma de suas intenções era a de analisar se o fenômeno dos vampiros seria natural, preternatural ou sobrenatural.

Em sua acepção, o sobrenatural se referia somente a Deus; o preternatural ao Demônio e o natural as causas "puramente físicas [puramente fisiche]" (DAVANZATI, 1774, p.69). Para realizar tal análise, o autor consideraria as narrativas sobre os vampiros de modo literal, ou seja, tomaria o vampirismo como verdadeiro, a princípio, para, a partir dos relatos, buscar uma resposta para a questão. É bastante similar ao exame de circunstâncias de dom 
Calmet, que também tomou os relatos como verdadeiros em um primeiro momento para, a partir deles, construir sua argumentação.

A proveniência divina do fenômeno estaria confirmada, para o autor, se os mortos retornassem em seus corpos originais. Dessa forma, estaria confirmado um milagre, uma ação de vitória sobre a morte, sobre a qual apenas Deus teria poder. Uma característica das lendas de vampiro, contudo, refutava essa possibilidade. Segundo o padre, ao mesmo tempo era possível ver a aparição do vampiro e "encontrar neste momento sepulto na tumba [trovare attualmente nella tomba sepolto]" (DAVANZATI, 1774, p.71) o cadáver. Além disso, a aparição sumia quando da destruição o cadáver. Para o autor, se Deus fosse o autor do vampirismo, nenhuma ação humana poderia impedir o fenômeno.

O Diabo poderia ser o responsável pelo fenômeno. De acordo com o autor, as a parições de mortos poderiam ser ilusões provocadas pelo Demônio. Sendo de natureza diabólica, não poderiam jamais ser ressureições verdadeiras, pois somente Deus teria esse poder. A obra diabólica, contudo, poderia dar movimento externamente ao cadáver, o que daria a impressão de que ele estaria realmente ressurreto (DAVANZATI, 1774, p.79). Isso, contudo, não passavam de artimanhas demoníacas que objetivavam imitar um poder que o Diabo não possuía.

Outra possibilidade era a de que o suposto vampiro não estaria realmente morto, seu sepultamento, portanto, teria sido "por qualquer acidente de apoplexia ou coisa similar [per qualche accidente di apoplesia o cosa simile]" (1774, p.79), o que o daria a aparência de morto. Nesse caso também o demônio teria participação, pois ele teria o poder de encerrar o estado catatônico 
do suposto falecido, o que, ressaltou o autor, era bastante diferente de realizar uma ressurreição. Da mesma forma ficaria injustificado o corpo que permanecia no túmulo.

A terceira opção que envolvia o poder diabólico era a possessão do cadáver em seu túmulo. Sem muito trabalhar a argumentação, Davanzati apenas declarou que "o demônio não tem poder de assumir os corpos dos mortos que estão em seus sepulcros [il demonio non ha potestà di assumere i corpi de'morti, che stanno ne'loro sepolcri]" (DAVANZATI, 1774, p.84). O Demônio poderia sim possuir corpos, inclusive de mortos, porém, de acordo com a Providência Divina, os corpos sepultados estariam protegidos destas incursões diabólicas.

Havia ainda uma quarta maneira de o vampirismo ser um fenômeno de proveniência demoníaca. De acordo com Davanzati, a aparição poderia ser um demônio em um corpo aéreo com aparência similar ao falecido. Esta explicação poderia facilmente ser aceita como verdade, pois dificilmente poderia ser contestada. Não havia problemas teológicos, como no caso da possessão de um cadáver sepulto. De acordo com o padre, a possibilidade de o demônio assumir um corpo aéreo seria sustentada pelo Malleus Maleficarum (1486) e pelo teólogo jesuíta Martín del Rio (1551 - 1608).

Davanzati declarou não querer se opor a essa corrente de pensamento, porém, no caso específico dos vampiros, não cria que esta fosse a explicação. O autor evoca a particularidade geográfica das aparições. Elas ocorriam "na pobre Morávia e Hungria superior [nella povera Moravia ed Ungheria superiore]", mas não "na França, e na nossa Itália [nella Francia, e nella nostra Italia]" (DAVANZATI, 1774, p.90). Além disso, para o autor não fazia sentido o demônio 
assumir apenas a aparência de camponeses e nunca de filósofos, cardeais e outras pessoas "de qualidade [di qualità]" (1774, p.91).

Esta última afirmação, contudo, poderia ter uma explicação. Segundo o autor, seria mais fácil para o demônio enganar "os idiotas e de baixa condição [gl'idioti e di bassa condizione]" (1774, p.91), do que os sábios e doutos. Pois aqueles, por influência do vinho, do sono ou do medo explicariam como diabólicos fenômenos que eram "puramente efeitos naturais [puramente effetti naturali]" (1774, p.92). Seria então, um engano, fruto da ignorância dos camponeses dos Bálcãs, que havia criado a lenda do vampiro.

Para Davanzati a Providência Divina não permitiria uma punição aos pecadores tal como o vampirismo. Muita gente morria de puro terror. Tal ato, não se encaixaria dentro dos planos divinos. O mais grave, para o autor, era a questão da profanação do túmulo, que ia contra todas as normas cristãs. Logo, não poderia ser uma punição permitida por Deus e executada pelo Diabo. O autor reforça sua opinião dizendo que em parte alguma da Bíblia há referência a esse tipo de punição (1774, p.93).

O modo de extermínio dos vampiros, para o autor, era uma prova de que o fenômeno não era divino nem demoníaco. Decapitar o cadáver, transpassá-lo com uma estaca e incinerá-lo eram atos físicos, naturais, sem nenhuma relação com o sobrenatural, ou o preternatural (1774, p.96). Se o vampirismo se encerrava com uma ação natural, ele não poderia provir de Deus ou do Diabo.

\section{AS RAZÕES FÍSICAS DO VAMPIRISMO}

Após uma grande discussão sobre os poderes do Demônio, Davanzati se propôs, no capítulo XII de sua dissertação, a analisar os 
motivos físicos para a aparição dos vampiros. A grande atenção do autor ao poder do Diabo estava em alinhamento com pensadores católicos modernos:

Ao longo do século XVII percebemos mudanças em vários conceitos demonológicos. Uma das percepções mais afetadas foi aquela que se refere ao poder do Diabo. Este passou de um poder mais concreto em realizar fenômenos sobrenaturais, para um poder de influência, enclausurado na Natureza. 0 Diabo foi como que desautorizado de seu poder tão forte conforme relatos e escritos medievais e passou a ser visto como um excelente físico, um grande conhecedor das potencialidades naturais e que por isso poderia realizar prodígios que nada tinham de sobrenatural. (BRAGA, 2018, p.23)

A Natureza, portanto, era o âmbito no qual restavam questões ainda desconhecidas, ocultas. Explicar os vampiros, do modo como eram retratados nos relatos, pela física não era possível. Nada permitiria a ressurreição de corpos mortos, sua sede de sangue e o fim das aparições quando da destruição do cadáver. Como não encontrou uma explicação física que pudesse dar conta do fenômeno, optou por publicar sua própria opinião sobre o assunto,

a qual consistirá em alegar uma causa simplesmente fácil, e natural, com a qual espero salvar, e reconciliar todas as aparências, circunstâncias e acidentes, que são narrados desses Vampiros pelos autores que descrevem a história desses até o dia presente.

[la quale consisterà in allegare una cagione semplicemente facile, e naturale, colla quale spero di salvare, e di riconciliare tutte l'apparenze, circostanze, ed accidenti, che si narrano di questi Vampiri dagli autori, che ne descrivono la storia di essi fino al giorno presente]. (DAVANZATI, 1774, p.158) 
O capítulo em que Davanzati apresentou sua teoria se intitula Da força da Imaginação [Della forza della Fantasia]..$^{13}$ Nele, o autor afirmou que "a solução deste grande fenômeno, não se encontra fora de nós, mas em nós mesmos [la soluzione di questo gran fenomeno, non si trova fuora di noi, ma in noi medesimi]" (DAVANZATI, 1774, p.159). A imaginação, para o padre, era responsável por todos os fantasmas, todas as aparições fantásticas, todos os mortos retornados. A imaginação era a única razão, "fora desta não há outra causa, dentro dela há tudo [fuori di essa non vi è altra causa, dentro di essa ci è tutto]" (1774, p.159).

A fim de definir o que era a imaginação, o autor recorreu a Aristóteles para destacar o seu caráter físico. Afirmou que a imaginação depende de uma membrana, que nos jovens é mais tenaz e conservaria melhor as imagens recebidas na memória, porém, nos mais velhos, essa membrana estaria já ressecada, o que prejudicaria a memória e a organização das imagens recebidas (1774, p.160). Davanzati cita René Descartes para sustentar sua teoria. De acordo com o filósofo francês, essa membrana se assemelharia a um "leque feminino [ventaglio di donna]" (1774, p.161), cujas partes dobravam e se amontoavam. Tal movimento produzia grandes efeitos:

acontece, que quando se vai dormir, depois de ter carregado com muito alimento o estômago, e este transmitindo à cabeça os gases, ou seja, vapores exalados pelo alimento, e estes no mesmo tempo com seu movimento de abertura, e dissolvendo as dobras dessa membrana, feita tal como em uma folha de leque, vêm-se algumas a abrir, e outras a

13 A opção pela tradução do termo Fantasia por Imaginação se justifica pela própria explicação de Davanzati, que afirmou que fantasia e imaginação eram a mesma coisa. 
permanecer fechadas, nas quais serão impressas imagens heterogêneas e diversas, as quais combinadas dessa forma, lhe foram apresentadas pelo sensorial comum à alma, vem a formar uma visão estranhíssima de objetos frequentemente monstruosos e quiméricos.

[ccade, che quando si va a dormire, dopo di aver caricato con molti cibi lo stomaco, e questo trasmettendo verso il capo i fumi, o siano vapori esalati dal cibo, e questi nello stesso tempo col loro moto aprendo, e sciogliendo le piegature di essa membrana, fatta come si è detto a foglia di ventaglio, si vengono alcune ad aprire, ed altre a restar chiuse, nelle quali vi saranno impresse specie etorogenee (sic), e diverse, le quali così combinate, presentatesi pel sensorio comune all'anima, viene a formarsi una veduta stranissima di oggetti spesse volte mostruosi, e chimerici (...)]. (DAVANZATI, 1774, p.161)

Se os vapores fossem produzidos por alimentos crus, ásperos e melancólicos, na classificação do autor, o agrupamento de folhas da membrana produziria imagens sombrias e melancólicas, sonhos terríveis.

A imaginação também era capaz de, a partir de fortes sentimentos, produzir uma espécie de comunicação à distância através do ar. Em outras palavras, os fortes sentimentos de alguém eram capazes de afetar a imaginação de outras pessoas (1774, p.164-165). Davanzati trata a imaginação como potência. Em suas operações a algo de maravilhoso, "quase mágico [quasi del magico]" (1774, p.168). A imaginação poderia inclusive influenciar na matéria, não só no próprio corpo da pessoa, como poderia ter efeitos em corpos de terceiros. 
Se a imaginação de uma mulher grávida poderia, de acordo com o autor, afetar o feto, ${ }^{14}$ o que não fariam as imaginações dos frenéticos e melancólicos? Mesmo que de forma não intencional, os fortes sentimentos de um para um grupo de pessoas ao seu redor poderiam ser transmitidos pelo ar através da imaginação. 0 momento do repouso noturno foi citado pelo autor como o reino da imaginação, à causa da formação dos sonhos. (1774, p.169-171).

O argumento principal de Davanzati é de que as aparições de mortos e fantasmas seriam todas frutos da imaginação. Em especial das imaginações corrompidas. ${ }^{15} \mathrm{Um}$ termo muito similar ao que dom Calmet utilizou em seu tratado. $O$ beneditino francês também defendeu uma tese parecida, de que os vampiros seriam frutos de imaginações feridas [imaginations frapées]. Um problema de imaginação, fazia com que a pessoa perdesse o controle sobre ela. Uma vez que Davanzati, e também Calmet, acreditavam que a imaginação poderia afetar a matéria, a falta de controle sobre a imaginação poderia criar lendas tais como a do vampiro e levar às pessoas de uma vila a acreditarem nos ataques a tal ponto que realmente poderiam adoecer e morrer.

A imaginação corrompida era a causa de males como o escorbuto, a hipocondria e mesmo uma espécie de tristeza que poderia levar pessoas a "matarem-se com as próprias mãos [uccidersi colle proprie mani]" (DAVANZATI, 1774, p.178). Esse problema de imaginação causaria a produção sem controle de imagens, podendo chegar ao ponto em que a pessoa não mais diferenciaria o imaginário do real, além de potencialmente afetar a imaginação de outros ao seu redor.

$14 \mathrm{O}$ autor cita como exemplo que, se uma grávida deseja comer morangos, mas não os consegue imediatamente, o bebê poderia nascer com pintas, tal como a fruta.

15 No original fantasia corrotta. 
“A verdadeira e única causa dos Vampiros, é a nossa Imaginação corrompida e depravada [la vera ed niuca cagione de' Vampiri, è la nostra Fantasia corrotta e depravata]" (1774, p.179). Os sonhos certamente poderiam parecer reais, porém, potencialmente falando, a imaginação também poderia agir fortemente durante os momentos despertos. Em uma imaginação corrompida, pouco faria diferença o dormir e o despertar. As imagens poderiam se formar sem controle, tanto em termos de produção quanto em termos de distinção do real e do ilusório.

Não havia nada na lenda dos vampiros além de imaginação e má-interpretação de efeitos naturais. A coloração vermelha dos cadáveres exumados, considerada sinal de vampirismo, era, para Davanzati, apenas uma "ilusione del lume [ilusão da luz]" (1774, p.202), ou então um efeito natural da decomposição do corpo. Quanto aos olhos abertos, o padre afirmou esta ser uma característica comum em cadáveres. Mesmo após a morte, o sangue poderia continuar fluído em alguns cadáveres, em especial naqueles que haviam sofrido morte violenta. Tal fluidez poderia levar a uma hemorragia de 3 ou 4 dias de duração, porém, Davanzati destacou um experimento que comprovou que a hemorragia do cadáver poderia durar até oito dias (1774, p.210).

Por fim, destaco a passagem em que fala da incorruptibilidade cadavérica, que era considerada tanto como um sinal de vampirismo nos Bálcãs, como um tradicional sinal de santidade para a Igreja Católica. Para Davanzati, contudo, a preservação do cadáver poderia ocorrer "sem ser sinal de santidade, ou de coisa miraculosa [senza esser segno di santità, o di cosa miracolosa]" (DAVANZATI, 1774, p.222). Tal condição possuía relações com o 
clima e o solo. O padre não descartou a incorruptibilidade dos corpos dos santos, porém, os santos seriam apenas aqueles institucionalmente estabelecidos.

Assim, os relatos de vampiros, apesar de apresentarem feitos fantásticos, não reportavam nada de diabólico, muito menos de divino. Não havia nada de sobrenatural no vampirismo. Os mortos-vivos sugadores de sangue que ganharam representações literárias já no começo do século XVIII não passavam de, na opinião de Davanzati, frutos de mentes corrompidas de camponeses balcânicos cuja alimentação era baseada em alimentos crus e melancólicos. Além disso, para somar aos efeitos da imaginação, a má-interpretação de efeitos cadavéricos naturais teria contribuído para o estabelecimento da figura do vampiro.

\section{CONSIDERAÇÕES FINAIS}

O objetivo principal de Davanzati foi o "de desenganar (...) aquela pobre gente, que se encontra submetida a este flagelo imaginário [di dissingannare (...) quella povera gente, che si trova a questo flagello immaginario sotoposta]" (1774, p.229-230). Para ele, o problema principal era a imaginação corrompida, responsável por visões fantásticas e exageros do real. Uma imaginação corrompida cujos efeitos eram elevados devida à alimentação dos camponeses balcânicos.

O principal problema relatado por Davanzati, em resumo, era a imaginação sem controle. É possível perceber

ao longo principalmente do século XVII, mas já em produções do final do século $\mathrm{XVI}$, o exercício de um controle sobre a imaginação que redirecionou 
os esforços investigativos para a Natureza, considerada como o lugar do indefinido e, por isso, merecedora das conjecturas dos filósofos. (BRAGA, 2018, p.20)

Davanzati fez parte do grupo de pensadores que, tal como Ranft e Calmet, desejavam explicar os fenômenos aparentemente sobrenaturais por meio da natureza. O alemão, dentre esses três, foi o mais radical. Davanzati e Calmet, devido às relações com a Igreja, ainda buscaram explicar e diferenciar o divino do demoníaco, porém o natural sempre era considerado a explicação mais correta.

O grande problema de uma imaginação corrompida, descontrolada, era a série de efeitos que isso poderia ter sobre a matéria, em especial o corpo. A crença no vampirismo realmente poderia levar uma pessoa à morte. O mais fantástico nas teorias modernas sobre os poderes da imaginação é que ela poderia causar malefícios a terceiros. O poder de influência de uma imaginação corrompida poderia ter tal a ponto de gerar pânico em uma vila inteira.

As teorias sobre as potencialidades da imaginação influenciaram na naturalização das investigações filosófico-naturais. Deus e o Diabo foram como que colocados em segundo plano e a natureza se tornou o âmbito preferido dos filósofos. Diversas eram as forças que ainda poderiam ser descobertas. A imaginação se firmou como uma das mais misteriosas.

É bastante interessante que até mesmo os clérigos negavam influências sobrenaturais e diabólicas no fenômeno do vampirismo. A associação do combate aos vampiros com os símbolos cristãos parece ser uma invenção do XIX. O mesmo se aplica à sexualização 
do vampiro, que aparece já nos primeiros poemas sobre o tema. Der Vampir (1748), do alemão Heinrich August Ossenfelder, já coloca um vampiro seduzindo uma jovem cristã. A faceta sedutora e conquistadora dos sugadores de sangue foi mais uma das criações literárias que modificaram a lenda dos vampiros para como a conhecemos atualmente.

A Dissertazione de Gioseppe Davanzati circulou por muito tempo em formato manuscrito e ajudou a disseminar a imagem do vampiro, inclusive o termo, que não era ainda comum. Nos periódicos e mesmo a dissertação do alemão Michaël Ranft os termos utilizados variavam entre mortos-mastigadores, Stryges e Upierz/Upyerz. O padre italiano foi autor de um dos primeiros trabalhos, talvez o primeiro, a utilizar o termo vampiro na Europa ocidental.

Apesar de desejar combater a crença em tais criaturas, Davanzati acabou contribuindo para o estabelecimento de características vampirescas que são frequentes até hoje no cinema e na literatura. As visitas noturnas, a estaca, o fogo e o sangue são elementos que desde o século XVIII caracterizam o modo de agir dos vampiros e a maneira de combatê-los.

\section{REFERÊNCIAS}

ARIÈS, P (2014 [1977]). O Homem Diante da Morte. Luíza Ribeiro (Trad.). São Paulo: Unesp.

ARGEL, M. \& MOURA NETO, H (2008). O vampiro antes de Drácula. São Paulo: Aleph.

ARTICLE Fort Extraordinaire (1693). Le Mercure Galant, Paris, p.62-71, mai.

BARBER, P (2010). Vampires, Burial \& Death: Folklore and Reality. New Heaven and London: Yale University Press. 
BRAGA, Gabriel (2015). Considerações Sobre a Figura do Vampiro e o Sobrenatural no Século XVIII a Partir da Obra de Dom Calmet (1672 - 1757). 104f. (Monografia - Graduação em História), Universidade Federal do Paraná, Curitiba.

(2018). O Natural e o Sobrenatural na Modernidade: a polêmica erudita sobre os mortos-vivos (1659-1751). 272f. (Dissertação - Mestrado em História), Universidade Federal do Paraná, Curitiba.

BUSTAMANTE, Regina (2011). "Festa das Lemuria: os mortos e a religiosidade na Roma Antiga". Anais do XXVI Simpósio Nacional de História. São Paulo: ANPUH, p.1-18.

CALMET, Dom Augustin (1751a). Traité sur les apparitions des esprits et sur les vampires ou les revenans de Hongrie, Moravie, etc. Tome I. Paris: Debure l'aîne. (1751b). Traité sur les apparitions des esprits et sur les vampires ou les revenans de Hongrie, Moravie, etc. Tome II. Paris: Debure l'aîne.

CEGLIA, F. P.de (2011). "The Archbishop's Vampires: Giuseppe Davanzati's Dissertation and the Reaction of "Scientific" Italian Catholicism to the 'Moravian Events'”. Archives Internationales d'Histoire des Sciences. 61(166-167), 487-510, jun./dez..

DAVANZATI, Gioseppe (1774). Dissertazione Sopra i Vampiri. Napoli: Presso i Fratelli Raimondi.

DELUMEAU, J (1989 [1978]). História do medo no Ocidente: 1300-1800, uma cidade sitiada. Maria Lucia Machado (Trad.). São Paulo: Companhia de Bolso. 


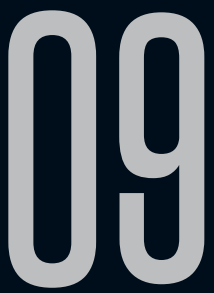

\section{VAMPIRISMO E CLAUSURA DO DESEJO EM O DESCONHECIDO E ANGÉLICA, DE LÚCIO CARDOSO}

Fernando Monteiro de Barros (UERJ-FFP) Leonardo Ramos Botelho Gomes (UERJ-FFP)

Recebido em 17 mar 2019. Fernando Monteiro de Barros é Professor Adjunto Aprovado em 14 mai 2019. de Literatura Brasileira na Faculdade de Formação de Professores da UERJ, onde atua no Programa de PósGraduação em Letras e Linguística (PPLIN) e desenvolve pesquisa sobre literatura gótica brasileira. É membro pesquisador do grupo (CNPq) Estudos do Gótico.

Leonardo Ramos Botelho Gomes é Mestrando em Estudos Literários do Programa de Pós-Graduação em Letras e Linguística (PPLIN), da Faculdade de Formação de Professores da UERJ, onde desenvolve pesquisa sobre os aspectos góticos no teatro de Lúcio Cardoso, sob a orientação do professor Fernando Monteiro de Barros.

Resumo: Lúcio Cardoso (1912-1968) é um escritor mineiro que apresenta em sua obra uma presença marcante de muitos elementos derivados da tradição literária do Gótico. O tema do vampirismo aparece tanto em um sentido metafórico na obra de Lúcio como na novela $O$ desconhecido, de 1940 - quanto no sentido literal, com aspectos plenamente calcados no sobrenatural, como na peça teatral Angélica, de 1950. Ambos os textos apresentam um traço específico do vampirismo, o daquele no qual a criatura, desprovida 
de qualquer beleza ou atratividade sexual, adota o comportamento de uma ave de rapina, a fim de dar vazão ao desejo enclausurado. Tal traço confere a estas obras uma dimensão ontológica, condizente com a categoria de autor de romances psicológicos na qual Lúcio Cardoso é enquadrado pelo cânone literário brasileiro.

Palavras-chave: Lúcio Cardoso; Literatura Gótica; Desejo; Vampirismo.

Abstract: Lúcio Cardoso (1912-1968) is a Brazilian author from Minas Gerais who shows in his work a remarkable presence of many elements derived from the Gothic tradition in literature. The theme of vampirism comes both in a metaphorical sense in Lúcio's work - as in the novel $O$ desconhecido (The unknown one), published in 1940 - and in a proper sense, in full-fledged supernatural colors, as in the play Angélica, written in 1950. Both texts depict a specific strain of vampirism, that of a creature who, devoid of any beauty or sex-appeal, adopts the behavior of a bird of prey, in order to let out the desire repressed within. That trait lends to these works an onthological dimension, in accordance with the psycological category where Lúcio Cardoso stands in the canon of Brazilian Literature.

Keywords: Lúcio Cardoso; Gothic Literature; Desire; Vampirism.

Lúcio Cardoso (1912-1968) é um escritor brasileiro do século XX em cuja obra são muito fortes os influxos da tradição gótica que se estabeleceu na literatura ocidental a partir do romance $O$ castelo de Otranto, do autor inglês Horace Walpole, publicado em 1764. Além disso, em sua produção literária é frequente a presença de personagens com vários traços vampirescos. Como afirma Nina Auerbach (1995, p.5), o vampiro não é um personagem monolítico, 
pois em cada ocorrência desse personagem na literatura ou no cinema este assume características diferentes, podendo ser belo e sedutor como os vampiros de John Polidori (The Vampyre, 1819) e Lord Byron (Fragment of a Novel, 1819), mas também grotesco e repelente, como o Conde Orlock do filme Nosferatu, do diretor alemão F. W. Murnau, de 1922. Dentre os vários personagens vampirescos de Lúcio Cardoso, destacamos aqui Aurélia, da novela O desconhecido (1940), e Angélica, do drama teatral homônimo de 1950, uma vez que, dentro da voltagem intratextual da obra de Lúcio, as duas personagens apresentam vários traços convergentes.

A presença do Gótico é ostensiva na obra de Lúcio Cardoso. Já o fantástico ocorre muito raramente na sua narrativa, porém mais frequentemente em seus dramas teatrais. No romance que inaugura a fase intimista de Lúcio, A luz no subsolo, de 1936, temos a presença do personagem espectral "mendigo resignado" (BARROS JUNIOR, 2002, p.43) e em quase toda a produção dramática do autor temos personagens que em um primeiro momento aparentam ser igualmente sobrenaturais. Contudo, na maior parte da obra de Lúcio o sobrenatural acaba sendo desconstruído por uma explicação racional, como sendo produto da loucura delirante dos personagens, revelando ser, assim, muito mais a ocorrência do estranho (TODOROV, 1975, p.48). Há, contudo, exceções, como o drama teatral Angélica, que mantém a presença do sobrenatural até o fim.

A grande maioria dos personagens do escritor mineiro manifesta um forte traço de transgressão aos valores da sociedade brasileira da época, marcada por um forte conservadorismo burguês (anos 30, 40 e 50 do século XX). Lúcio era um intelectual que não aderia 
a este etos e nem tampouco nutria simpatia pela ideologia de esquerda. Desviante ao extremo, o pensamento político de Lúcio assemelhava-se ao de Baudelaire e ao dos escritores decadentistas franceses do final do século XIX, em seu desdém pelos valores democráticos e em seu culto à aristocracia. Não por acaso, sua obra apresenta um forte legado do imaginário gótico e da poética do Decadentismo, estilos literários afins, marcados pelo mote da majestade em ruínas e pelo entrecruzamento de sexualidade e morbidez, que tem no vampirismo a sua principal metáfora. Assim como no Gótico, o espaço assume importância capital na obra de Lúcio Cardoso, que enfatiza a criação de uma atmosfera tenebrosa, ao evocar ambientes decadentes, tanto provincianos quanto urbanos, representantes de uma tradição extinta que teima em permanecer na modernidade.

A narrativa de $O$ desconhecido, denominada "novela" e não "romance" por seu autor, tem como protagonista um homem atormentado, de passado infeliz, que troca a cidade pela província, e vai exercer uma função subalterna na fazenda arruinada e decadente de Aurélia, uma senhora aristocrática e soturna. $\mathrm{O}$ aspecto central do enredo é que tanto Aurélia quanto José Roberto (o "desconhecido" do título) sofrerão uma espécie de enclausuramento desejante compulsório pelo motivo de não serem dotados de beleza, o que contrasta fortemente com a situação dos personagens Paulo, empregado da fazenda, e Nina, filha da criada de Aurélia, ambos jovens, belos e apaixonados, que são caracterizados ao longo da trama como seres que vivem completamente livres. Paulo acaba se tornando o objeto amoroso de José Roberto, enquanto sua namorada Nina é expulsa da 
fazenda por inveja de Aurélia, que, por sua vez, vislumbra em José Roberto a possibilidade de dar vazão a seu desejo.

O enredo enfatiza, assim, a oposição entre beleza/liberdade e fealdade/enclausuramento. A majestosa dona da fazenda sofre com "o mistério da sua vida, a força de seu destino solitário" (CARDOSO, 1969, p.163), por reconhecer como causa de seu infortúnio o fato de que "toda ela era repelente" (p.167). Enquanto crescera "isolada no ambiente abafado de uma família em decadência, uma dessas pobres flores envenenadas pelas atmosferas em decomposição" (p.169), corroída pelo "desejo mortal de viver o mais intensamente possível" (p.169), Nina, por sua vez, fora crescendo "solta por aí, como um bicho selvagem" (p.123) até o dia em que Aurélia "encontrou-a se banhando no rio" (p.123) e, invejosa de sua beleza, após tentar com uma grande tesoura cortar-lhe os cabelos, expulsou-a da fazenda (p.123). A inveja que Aurélia sente dos atributos físicos de Nina é explicitada quando afirma: "Não posso vê-la, não posso nem sequer lembrar-me de que ela existe. É jovem, é bela..." (p.166). Ao que acrescenta, desolada:

Como é bela, meu Deus, como é bela! Nunca vi na minha vida cabelos iguais, pele mais sedosa, olhos mais brilhantes. Nunca vi fascinação mais poderosa. Pensei em deixar tudo, em me recusar a tomar um partido definido. Mas a pequena crescia a olhos vistos, criava formas, atraía todos os olhares, invadia a fazenda inteira com o seu esplendor. Onde quer que fosse, eu a via, estuante de saúde. Como era possível viver desse modo, eu, que nunca tive nada, que sempre fui feia e escarnecida? Não tive forças para perdoá-la. Expulsei-a. [...] Essa menina é uma negação da minha própria existência. (CARDOSO, 1969, p.171) 
No Ocidente tributário da hegemonia do pensamento apolíneo, ratificado pela metafísica platônica que equiparava a beleza à razão, à verdade e à divindade (PLATÃO, 1989, p.64-69), os velhos, os feios e os fisicamente repulsivos, nas narrativas tradicionais, sempre se encontraram dificultados no acesso a Eros. Nas narrativas ocidentais, a dicotomia entre heroísmo e vilania tradicionalmente sempre pressupôs atributos de beleza nos heróis, brindados ao final com o amor, e características de fealdade nos vilões, quase nunca amantes ou amados. Por outro lado, nos rituais que celebravam os mistérios dionisíacos, a dissolução das fronteiras do que seria o ego individual se dava, além de na embriaguez e na loucura sagrada, também na orgia, na qual Eros se democratizava (PAGLIA, 1992, p.99-100), permitindo o seu acesso a todos, independentemente de serem dotados ou não de beleza. O sofrimento de José Roberto e Aurélia na narrativa de $O$ desconhecido atesta o exílio amoroso dos não dotados de beleza física nas narrativas da civilização apolínea ocidental, condenados a experimentarem o desejo enquanto clausura.

No entanto, Aurélia e José Roberto mal conseguem controlar o incontrolável: a voracidade de seus desejos de fusão erótica. Sem saber da inclinação homoafetiva de José Roberto, Aurélia projeta sobre ele seus arroubos desejantes, o que por ele é percebido: "José Roberto não se enganava: sentia nela a contenção das feras, que estudam antes o salto para não perderem a presa" (CARDOSO, 1969, p.160).

Atestando o dado ostensivamente cenográfico do vampirismo literário (FRAYLING, 1991, p.6), mero fingimento poético, o enredo sugere contornos vampíricos ao personagem de Aurélia a partir das poses do gênero. No começo da narrativa de $O$ desconhecido, José Roberto, ao ver Aurélia pela primeira vez dentro do coche em 
que era conduzida pela estrada poeirenta, "percebeu que uma mão descarnada tinha-se pousado no rebordo da janela, e, examinando-a bem, viu que qualquer coisa emprestava a esses dedos afilados uma particular expressão de avidez", como se os dedos de Aurélia "estivessem tateando os objetos, numa carícia silenciosa de quem ocultasse ao mesmo tempo a sinistra intenção de devorálos" (CARDOSO, 1969, p.116). Estas mesmas mãos de Aurélia são também referidas na narrativa como "garras abertas" (p.164). O aristocratismo dos vampiros da literatura também se faz presente, pois "um anel de prata, com um enorme rubi, parecia comunicar a essa mão uma nobreza gelada" (p.116). Ao finalmente conseguir vislumbrar o seu rosto, José Roberto percebeu que Aurélia "era uma mulher de idade, vestida de escuro, a gola alta presa por uma pedra idêntica à que trazia no dedo. De cabeça erguida, toda ela parecia irradiar uma sombria e desdenhosa majestade" (p.116). Embora não pudesse "ver detidamente os traços de sua fisionomia", "sobravaIhe em compensação a sugestão avermelhada do ambiente, feita pelo reflexo da lanterna e pelo veludo escuro que forrava as almofadas do banco e que parecia mergulhar aquela figura solitária numa espécie de atmosfera diabólica" (p.116). A caracterização de Aurélia, assim, reveste a personagem de feições vampirescas e com os atributos de uma ave de rapina.

A esse respeito, Luiz Costa Lima, ao analisar a obra de Cornélio Penna, escritor da mesma lavra de Lúcio Cardoso, conceitua a violência da sexualidade enclausurada a partir da metáfora da ave de rapina, noturna, sempre à espreita para cravar suas garras quando o momento se apresenta propício (LIMA, 1976, p.70). Em Fronteira, primeiro romance de Cornélio, publicado em 1935, a 
personagem Maria Santa, considerada milagreira pela população do lugarejo mineiro em que vive, não tem outra forma de dar vazão ao furor de sua mal contida sexualidade, conforme diz o Narrador, alvo dos arroubos da jovem beata. O trecho abaixo citado é extraído do capítulo XXXIV, que começa com um passeio que o Narrador e Maria Santa dão no jardim "silencioso e devastado", tarde da noite. O Narrador diz a Maria Santa para irem embora, já que um arrepio os faz estremecer:

- Mas você é que está com medo... - respondeume, e deu uma risada clara, mas logo imobilizou-se, rígida, à escuta, como se esperasse a resposta ao seu desafio.

Depois, afastou-se de mim, e perdeu-se na sombra, que se tornara espessa, compacta, como se tivesse caído sobre mim um bloco de massa negra.

Fiquei por muito tempo esperando, à espreita, a perscrutar ansiosamente em torno, e sentia cada vez mais longe, cada vez maior o meu abandono.

[...]

Senti, depois, uma mão trêmula agarrar-me o braço, e unhas, em garra, enterraram-se na minha carne. Um bafo quente chegou-me até a boca, adocicado e morno, e senti que todo o meu corpo se encostava a outro corpo, em um êxtase doloroso e longo, inacabado e insatisfeito...

Quando voltei a mim, procurei afastar com violência o monstro que viera das trevas, mas estava só de novo, e voltei para casa, sem procurar explicar o que me sucedera... (PENNA, 1958, p.65)

Com relação à passagem supracitada, assegura Costa Lima que podemos "associar o uso das garras aos espasmódicos acessos de 
febre sexual da personagem" (LIMA, 1976, p.70). "Garras" são, pelo crítico, associadas à "ave noturna", à "espreita" e à "violência da sexualidade". Ao concluir que "o próprio da ave de rapina é o uso de garras", Costa Lima elege, assim, o paradigma da ave de rapina como metáfora por excelência desta configuração da violência da sexualidade (LIMA, 1976, p.70). De fato, em $O$ desconhecido, em um dado momento a narrativa se refere a Aurélia como possuidora de um "cruel perfil de ave de rapina" (CARDOSO, 1969, p.133).

Esta modalidade violenta, noturna e predatória do desejo sexual tem, desde a literatura gótica do final do século XVIII, sua mais recorrente metáfora no vampiro, figura mítica legada pelo Romantismo (GLADWELL, 1999, p.7). Enfeixando o amor e a morte (GLADWELL, 1999, p.7), os vampiros têm uma ligação indiscutivel com as potências daimônicas de Eros: o romance Drácula, de 1897, coloca como principal ameaça do vampirismo a insaciabilidade de seu desejo sexual (HINDLE, 1993, p.IX), tão mais ameaçador por ser percebido enquanto força incontrolável da natureza em sua indiferença arcaica (BELSEY, 1994, p.176-177). Neste sentido, os vampiros apresentam uma dimensão dionisíaca indiscutível e, curiosamente, além do próprio deus Dioniso também ter sido associado, por Eurípides, em As bacantes, a um caçador sedento de sangue (OTTO, 1995, p.109), os rituais em sua homenagem culminavam na omofagia, ou seja, a "consumação imediata do sangue e da carne crua" da vítima sacrificial, geralmente um touro ou um bode, após seu dilaceramento (diasparagmós, em grego) pelos praticantes do culto (BRANDÃO, 1988, p.137).

São várias as representações do vampiro, na literatura ocidental, e também no cinema, enquanto predador sexual noturno 
e oportunista, que estuda cuidadosamente a vítima e se lança ao ataque quando o momento se mostra propício, tal como fazem as aves de rapina. Em Aurélia, seus traços vampíricos se traduzem na necessidade de dissolver aquilo que na cultura ocidental, desde a época clássica em Atenas, constituía o princípio de individuação, que era rompido pelo sparagmós dionisíaco, já que na narrativa a aristocrática senhora da fazenda "precisa de alguém, de uma alma que seja sua, que esteja sob o seu domínio como um objeto que pode ser estraçalhado a qualquer momento" (CARDOSO, 1969, p.224), perpassada que é pelo "mais animal dos desejos, a mais violenta e a mais inútil das paixões, esse absurdo e tenebroso desejo de posse, essa vontade de reduzir e aniquilar, que nos habita como o mais diabólico sinal da natureza humana" (p.225). Não logrando seu intento, entretanto, Aurélia permanece durante toda a trama "encerrada dentro de si mesma, como num inviolável sepulcro" (1969, p.223), amargando "o mistério da sua natureza solitária, mergulhada nas trevas, sem nenhuma crença, sem nenhum amparo, sem outro caminho que o seu perpétuo rancor" (1969, p.223).

O vampirismo enquanto metáfora da clausura do desejo, no entanto, adquire nesta novela dimensões ontológicas e existenciais mais amplas: "A solidão daquela mulher pareceu-lhe um monstruoso castigo. Mas não pertencia somente a ela, como um abominável privilégio, era uma espécie de maldição lançada sobre o gênero humano" (1969, p.227). A seguinte passagem da Imitação de Cristo, texto medieval da Igreja Católica, já reconhecia o corpo como clausura, submetido à tirania do desejo sem fim:

Em verdade, grande miséria é viver na terra. Comer, beber, velar, dormir, descansar, trabalhar, 
estar sujeito às demais necessidades da natureza é, de fato, grande miséria e aflição para o homem... muito oprimido se sente, com efeito, o homem interior com as necessidades do corpo. (KEMPIS, 1948, p.44)

A literatura acabou dando contornos eróticos e aristocráticos ao mito do vampirismo, inexistentes na tradição folclórica a respeito (TWITCHELL, 1997, p.7), segundo a qual os vampiros eram camponeses mortos que voltavam de suas tumbas apenas para sugar o sangue de seus familiares ainda vivos, ou seja, tendo como finalidade última apenas aplacar a sua sede omofágica. Em pleno século XVIII, no momento em que o lluminismo está prestes a proclamar a supremacia da máxima cartesiana e da objetividade da verdade, surgem na imprensa, nos decênios de 1720 e 1730, relatos sobre casos de vampirismo em aldeias do leste europeu. É a poesia alemã que inaugura a linhagem literária dos vampiros, a partir de "Der Vampir" (1748), de Heinrich August Ossenfelder, "Lenore" (1773), de Gottfried August Burger e "Die Braut von Korinth" ("A Noiva de Corinto", 1797), de Goethe (TWITCHELL, 1997, p.33). Principalmente em "Lenore" e no poema de Goethe, a fome do vampiro é de "amor, não de sangue" (p.34).

O mito do vampiro, assim, se solidificou no imaginário ocidental não só pela tradição folclórica e subsequentes relatórios oficiais e médicos documentados por toda a Europa no século XVIII, mas, principalmente, por suas diversas manifestações artísticas, culminando com as cinematográficas, e contando com uma extensa tradição literária, que surge nos setecentos, percorre a literatura penny-dreadful oitocentista, até os romances de uma Anne Rice, por exemplo. A revisitação de produções literárias da temática 
do vampirismo ressalta, curiosamente, que as abordagens iniciais do vampiro na literatura são fundamentadas na figura feminina, sobretudo na produção poética, como confirmam Martha Argel e Humberto Moura Neto (2008, p.25).

Théophile Gautier, Bram Stoker e Sheridan Le Fanu também são exemplos de escritores que solidificaram o tema da mulher vampiro, da qual seria também a origem da vamp moderna, definida pelo Shorter English Dictionary como: "uma mulher que se esforça para encantar ou cativar os homens (frequentemente por razões desonestas ou discutíveis) utilizando sua atração sexual sem escrúpulos" (Apud LECOUTEUX, 2005, p.30). Em geral, conforme salienta Claude Lecouteux, "de uma fria crueldade, exigindo abandono total e volúpia", estas mulheres "se deleitam com a dor e a lenta agonia da vítima" (2005, p.30).

A balada de Goethe "A Noiva de Corinto", que, segundo Mario Praz, seria o primeiro comparecimento literário sério do tema do vampirismo (PRAZ, 1996, p.89), vincula a sede de amor vampírica à clausura. Em vinte e oito estrofes, o poema narra o ataque vampírico sofrido por um jovem rapaz, vítima da sede de amor da Noiva de Corinto do título, que, neste texto fundador, já adota a postura de ave de rapina (GOETHE, 1999, p.110-121):

Porém, do aprisionamento de minha tumba, Por uma lei extraordinária sou forçada a sair e vagar Enquanto as bênçãos e os cânticos de seus padres Se mostram ineficazes;

O sal e a água em vão tentam Subordinar os sentimentos ardentes.

Ah, nem mesmo a terra pode esfriar o amor!

Este rapaz fora primeiro prometido para mim Enquanto o alegre templo de Vênus ainda existia. Mãe, quebraste a tua palavra 
Constrangida por um falso e estrangeiro voto.

Mas os deuses não escutam

Quando uma mãe promete

Negar a mão de sua filha prometida.

Sou forçada a sair de meu túmulo

Para continuar a ir atrás das coisas boas de que sinto falta,

Para continuar a amar o homem já perdido,

E sugar o sangue vital de seu coração.

Se agora ele está condenado,

Devo procurar outros

Os jovens sucumbirão à minha fúria.

Belo rapaz! Tu não podes mais viver;

Irás definhar neste leito.

Eu te dei o meu cordão;

Eu levarei comigo um cacho de teus cabelos

Mira-o bem!

Amanhã estarás grisalho,

E apenas aí teu cabelo permanecerá castanho.

Os versos acima explicitam a conexão não apenas entre vampirismo e erotismo, mas também entre desejo e clausura. O poema parece também estabelecer um elo entre vampirismo e as potências dionisíacas, pois deixa claro que os alegres e festivos deuses pagãos, Ceres, Baco (Dioniso) e Vênus, são substituídos pelo cristianismo "dos Céus", mas em vão, pois os decretos do alto não conseguem sufocar o desejo daimônico que ferve mesmo "embaixo da terra" (GOETHE, 1999, p.110-121). O céu patriarcal não consegue, assim, submeter a terra matriarcal, apesar das preces e cânticos dos padres. E, assim como Aurélia de $O$ desconhecido, a "noiva" de Corinto se sente furiosa por sua clausura impedi-la de participar do jogo erótico e amoroso do mundo cristianizado e apolinizado, vingando-se, portanto, com 
o jugo e a destruição que exerce sobre os homens que caem em suas garras.

O poema também parece estabelecer, na literatura ocidental, a partir do próprio mito do vampirismo, o "tema do fantasma erótico", muito vasto na literatura moderna (PAZ, 1994, p.62), visitante noturno que visa muito mais a consumação amorosa impossível do que meramente a saciedade de uma sede por sangue, vampirismo assim muito mais metafórico do que literal, uma vez que o sangue parece avultar como metáfora do ardor erótico. 0 vampirismo folclórico, ao contrário, continha apenas o elemento da monstruosidade enquanto violência antropofágica, da criatura se alimentando de outra criatura com quem teria laços de parentesco.

O vampirismo metafórico de Aurélia, portanto, parece ter sua matriz verificável nestes primeiros textos românticos sobre o tema. Talvez o mais contundente exemplo de clausura desejante vampírica relacionada a uma aparência repelente esteja em um filme alemão muitos anos posterior à morte de Lúcio Cardoso, Nosferatu, Phantom der Nacht, de Werner Herzog, refilmagem do clássico de Murnau. O filme, de 1979, também associa vampirismo a desejo insaciável, numa perspectiva melancólica, refletindo os impasses e as aporias da condição humana. Visualmente repulsivo, o vampiro deste filme lamenta atravessar os séculos incapaz de consumar o desejo de amar, evidenciando o corpo como clausura, conforme as passagens extraídas de $A$ imitação de Cristo. "O tempo é um abismo tão profundo como mil noites... A morte não é o pior, é bem mais cruel ser incapaz de morrer... A ausência do amor é a dor mais abjeta que existe...", diz o conde-vampiro do filme, que também recorre à postura de ave de rapina, sempre à espreita, não 
hesitando em avançar sobre o objeto do desejo quando o momento se mostra propício, como acontece na cena em que agarra a mão de Jonathan Harker que havia se cortado com uma faca ao partir o pão e suga-lhe o sangue apaixonadamente.

O vampirismo enquanto produto da criação literária, assim, ganha dimensões ontológicas ao se apresentar como metáfora da condição humana de se estar enclausurado em um corpo desejante mesmo após o desaparecimento da juventude e da beleza física. A esse respeito, um dos maiores estudiosos acadêmicos do vampirismo na literatura, James B. Twitchell, insiste em afirmar que o vampiro "vive para o amor, não para o sangue" (TWITCHELL, 1997, p.51).

Se com Aurélia o vampirismo se coloca enquanto metáfora erótica e ontológica, no drama teatral Angélica o tema do vampirismo pela primeira vez comparecia na obra de Lúcio Cardoso de forma explícita, e não apenas metaforizada. Filho da tradição gótica, o vampiro também é um personagem da literatura fantástica por excelência, dada a sua condição de criatura sobrenatural que ameaça o mundo da realidade empírica (ROAS, 2014).

A relação de Lúcio Cardoso com o teatro se configurou conturbada, oscilando entre a empolgação de contribuir para a renovação do teatro brasileiro e as decepções nas montagens dos textos e as subsequentes reprovações críticas por parte dos jornais da época. Após a representação de Angélica, cuja personagem principal fora interpretada pela atriz Luíza Barreto Leite, Lúcio escreveria em seu diário que "não, não, é completamente inútil voltar ao teatro. Angélica marcou definitivamente a minha última tentativa" (CARDOSO, 2012, p.311). Parte do desgosto relacionavase com a crítica, que parecia não apreender seu drama em totalidade. 
A respeito do que escreviam sobre o mesmo, Lúcio desabafa: "artigo de determinado crítico sobre Angélica, respirando uma tal estupidez uma tão grande má vontade, uma desonestidade tão veemente, que me põe perplexo [...] isto é que é o pior no teatro: colocar-nos ao alcance de imbecis desta espécie" (CARDOSO, 2012, p.314). Como acontecera com grande parte das encenações de seus textos dramáticos, este também não obteve grande êxito: "Angélica, levada à cena ontem, num teatro minúsculo e pouco confortável, constitui mais um fracasso para se juntar à série que me vem perseguindo ultimamente" (CARDOSO, 2012, p.311). É provável que tanto o público quanto a crítica tenham assistido Angélica com uma expectativa baseada em pressupostos veristas e tenham estranhado "o artifício e a irrealidade" que caracterizam as peças teatrais de Lúcio Cardoso (PRADO, 2006, p.389).

O estudo do drama de Lúcio Cardoso contribui para o reconhecimento da coesão de seu projeto artístico, visto que manifesta temáticas e atmosferas presentes em outras de suas produções, o que atesta o alto grau de intratextualidade dentro da obra do autor. Antonio Arnoni Prado, no posfácio que integra a edição dos dramas teatrais de Lúcio Cardoso (Teatro reunido, 2006), reconhece que "parece hoje inegável que a sua dramaturgia é a contraparte indispensável à compreensão e ao aprofundamento dos temas presentes no corpo de sua prosa e na origem latente de seus diários" (2006, p.386), o que, de fato, atesta a unidade que entrelaça suas obras. Prado caracteriza os dramas teatrais de Lúcio como sendo dotados "de gestos vigilantes e de olhos sempre dissimulados em razão da maldade e da descrença" (2006, p.386), de modo a reconhecer "a obscuridade das coisas e dos seres, o 
clima de mistério que se integra à paisagem de sua prosa e recobre de incertezas a atmosfera das casas" (2006, p.387), mas parece se decepcionar com o que considera "literatice e insinceridade" nos dramas teatrais de Lúcio (PRADO, 2006, p.389).

É relevante considerar que Lúcio "escolheu inscrever-se na tradição do 'drama psicológico', com crises, mortos, situações paroxísticas, na linha de Ibsen, Strindberg, Tchekhov", afirma Mario Carelli (1988, p.99). Nos diários, Lúcio registrara diversas leituras dramáticas; Carelli pontua alguns desses autores considerando o "temperamento trágico" de Lúcio, o qual o teria levado não apenas aos gregos, mas também ao teatro elisabetano de William Shakespeare, Ben Johnson, Dekker, além do interesse por Christopher Marlowe, Jean-Paul Sartre, Albert Camus e, mais tardiamente, Jean Genet (CARELLI, 1988, p.89).

A trama de Angélica tem como protagonista uma senhora aristocrática, muito semelhante a Aurélia, que acolhe jovens desvalidas em seu grande casarão sob o pretexto de protegê-las. As jovens, no entanto, acabam definhando e morrendo sempre, enquanto Angélica se mantém a cada dia mais remoçada.

Até a publicação do Teatro reunido de Lúcio Cardoso, organizada por Antônio Arnoni Prado em 2006, a peça só estava disponível para leitura nas sessenta e nove laudas datilografadas por Lúcio que se encontram em seu arquivo no Setor de Literatura Brasileira da Fundação Casa de Rui Barbosa, no Rio de Janeiro, de onde colhemos as transcrições a seguir.

O cenário da casa de Angélica apresenta elementos decorativos que poderíamos encontrar nas descrições dos espaços góticos: "móveis 
antigos", "quadros e medalhões nas paredes", "um vasto espelho de moldura dourada", "castiçais variados de cristal e prata" (CARDOSO, 1950, fl.1). Angélica "é uma solteirona de meia-idade, pálida, extravagantemente vestida, com um luxo fantástico e demodée" (fl.1). Traz também, como Aurélia, "jóias excessivas, demonstrando uma visível vaidade" (CARDOSO, 1950, fl.1).

A relação hierárquica demarcada entre Angélica e seu capataz Leôncio muito lembra a de Aurélia e seu capataz Miguel e a de Aurélia e José Roberto, em $O$ desconhecido. Não apenas por uma tentativa de dominação por parte das personagens femininas, mas também pelo fausto que as duas personagens ostentam. A considerar a indumentária, nota-se um luxo aristocrático démodé, já em desuso, relativo a uma ordem social decadente, sobrepujada por um novo mundo no qual Angélica parece não se encaixar. Estaria, assim, encerrada em sua condição antiquada frente às mudanças sociais e, assim, apresentando um aspecto de fantasma do passado a assombrar o presente, um dos traços principais da literatura gótica. Sua própria casa, provinciana, é ornamentada com objetos e móveis, como já listado acima, pertencentes a outras linhagens, como o símbolo de um período histórico já desaparecido que insiste em se prolongar. Sabe-se que a narrativa gótica "nunca se desliga dos problemas da sua época", pois seria "fortemente condicionada pelo seu contexto social" (MONTEIRO, 2004, p.139), o que atesta o desenvolvimento e adaptação do Gótico ao longo dos séculos em cada contexto, estabelecendo a tensão entre uma nova configuração social e o passado que tende por incidir nesta, o que não deixa de revelar as tensões entre tradição e modernidade, um dos eixos temáticos mais importantes da segunda fase do 
Modernismo brasileiro, além de ser um dos dados mais relevantes da cultura brasileira como um todo.

A peça começa sob o signo da clausura: a criada Joana pergunta à sua senhora se esta não tem medo de abrir a janela, ao que Angélica responde estar fechada "neste quarto" desde que a última jovem adoecera. Na cena em que recebe a visita de senhoras da cidade, Angélica explica que a jovem, Maninha, morrera de um "mal misterioso". "Sempre morrem as minhas protegidas" (CARDOSO, 1950, fl.6), lamenta Angélica, embora as moças sejam sempre "tratadas como se fossem rainhas" (fl.7). As senhoras de visita exclamam: "Ultimamente a senhora parece ter remoçado vinte anos!"; "Exatamente, a senhora parece remoçada, outra!" (fl.8). O monólogo de Angélica, após a saída das visitantes, explica a razão do rejuvenescimento e sugere a especificidade de sua natureza "ávida de prazer":

Disseram que estou remoçada... como se tivesse readquirido vinte anos. $\mathrm{O}$ que esta gente fala sem compreender! Quantas poderão como eu alisar assim o oval da face, experimentar as rugas que mal se denunciam, prender estes cabelos ainda negros? Ah, quantas poderiam dizer realmente minha idade? Este vigor, este impulso para a vida... Talvez o que me conserve seja a consciência de que ainda desejo tanto quanto da primeira vez: nada extinguiu a minha sede, o sangue que corre nas minhas veias ainda é quente como da primeira mocidade! É hoje que o milagre se renova, sinto que o mistério é de uma energia constante, o de uma fonte perpetuamente a ferver dentro de mim! (CARDOSO, 1950, fl.8-9)

Angélica pede a seu capataz Leôncio que traga para ela uma nova rapariga, mas que seja "sã" e ao mesmo tempo "de uma 
constituição frágil de quem eu possa cuidar, a quem possa dedicar o meu carinho, os meus cuidados" (CARDOSO, 1950, fl.10). Ressalta que a nova jovem seja "delicada... ainda moça... bonita, se possível" (fl.10). Leôncio sugere uma jovem que brigara com o namorado e com a própria mãe, ao que Angélica ordena: "Traga, traga este lírio selvagem! É dele que eu preciso" (fl.13).

Comentários suspeitos começam a circular pela cidade. A criada Joana se recorda de que ao ver o rosto de Maninha morta se deparara com "uma velha, um ser enrugado", parecendo "que Ihe arrancaram alguma coisa à força, que sugaram dessa coisa morta toda a sua energia" (CARDOSO, 1950, fl.18) - Nos originais, esta última frase encontra-se riscada por seu autor, como se não quisesse ir além da mera sugestão, sem cair no terreno do explícito, mas julgamos relevante transcrevê-la aqui. O final do primeiro ato registra mais um monólogo de Angélica, diante do cadáver de Maninha. Os trechos entre colchetes encontram-se riscados por seu autor, mas optamos por transcrevê-los devido à sua relevância para o tema em questão:

Velha! Velha e triste, como as que murcham no asilo, como as que andam por aí pedindo esmola! [Você ouviu, Maninha, você ouviu bem? Ninguém poderia reconhecer o seu rosto: essa pele queimada e frouxa, esses cabelos colados às têmporas, essa boca escura. Nunca mais você verá a luz do sol nem poderá passar a mão no seu próprio rosto, nem se olhar no espelho! É, todos dizem que eu estou cada dia mais moça, que rejuvenesço, que os meus olhos brilham como se eu ainda tivesse um namorado! Olhe para os meus ombros, veja a minha pele branca, os meus cabelos longos e sedosos! Veja como eu me acaricio, como adoro 
essa pele que é minha, como me beijo e suspiro de alegria!] Ah, Maninha, não adiantou você morrer enquanto fui buscar o copo d'água... [Aqui estou eu, moça, ardente, apesar de você me ter roubado o seu último suspiro, aquele de que mais tinha necessidade!] (CARDOSO, 1950, fl.19).

O trecho acima confirma os jogos de intratextualidade presentes na obra de Lúcio Cardoso, no que Angélica consuma com Maninha, o que Aurélia gostaria de conseguir com Nina: sugar sua juventude e sua beleza. As alusões intertextuais também se confirmam, no que a história de Angélica apresenta semelhanças indiscutíveis com os episódios envolvendo o "supermodelo histórico" do vampirismo segundo Laurence Rickels, a condessa húngara Elisabeth Báthory, levada aos tribunais em 1611 por haver causado a morte de seiscentas e cinqüenta moças em cujo sangue se banhava para se manter bela e jovem (RICKELS, 1999, p.12). Vários filmes foram inspirados em sua história, que guarda também semelhanças com a clausura e a tortura imposta aos jovens pelos libertinos poderosos no castelo de Silling em 120 dias de Sodoma, do Marquês de Sade (BARTHES, 1990, p.21).

No segundo ato, Leôncio traz para Angélica a jovem Lídia, que não compreende o interesse da senhora em sua permanência na casa já que não terá que desempenhar nenhuma função serviçal. Angélica diz precisar de uma dama de companhia. O trecho que se segue denuncia o vampirismo da personagem:

Angélica - Quero-a junto a mim, como uma companheira, uma filha. Sabe o que é ser filha atenta e carinhosa?

Lídia - Mas a senhora nem me conhece! 
Angélica - Que importa? E este sangue quente que corre nas suas veias, esta energia e este calor concentrado?

Lídia - É disto que a senhora precisa?

Angélica - É disto. (CARDOSO, 1950, fl.24)

Angélica persuade Lídia, prometendo lhe deixar seus bens como herança. Ao ser indagada pela jovem sobre a morte das outras três moças, responde: "exalaram junto de mim o último suspiro. E nós, os vivos, que devemos a estes pobres seres fora dos limites? São prisioneiros, e a nossa liberdade é imensa" (CARDOSO, 1950, fl.28), reafirmando, como em $O$ desconhecido, a equivalência entre vida juventude - beleza - liberdade, e entre morte - velhice - fealdade - prisão - clausura. Os mortos, os não-belos, os não-jovens, em Lúcio Cardoso, a partir de uma das vertentes da tradição literária do vampirismo, não podem dar vazão a seu desejo, não podem amar, a não ser que ataquem seus objetos de desejo como aves de rapina. A clausura da noiva de Corinto goethiana, como vimos, era conseqüência de sua condição de morta.

No terceiro ato Lídia está doente, perdendo a energia à medida que Angélica a sufoca com casacos de pele e cobertores (CARDOSO, 1950, fl.47). Leôncio se sente culpado e acaba expondo a Lídia os reais desígnios de Angélica: "mas não compreende, não sente que ela está lhe sugando a energia, que tem necessidade disto como uma seiva para viver?" (fl.49). Lídia e as demais jovens que definharam na casa de Angélica não deixam de apresentar traços em comum com o paradigma gótico da "donzela perseguida". Leôncio passa a antagonizar a sua senhora, a quem se refere desdenhosamente, assinalando sua monstruosidade: "Há muitas 
coisas que não compreendemos ainda e uma delas é o mistério dessas naturezas sequiosas. São seres raros, espécie de plantas que empestam e viciam o ar com o próprio perfume. Mas nem é perfume, é veneno o que escorre no fundo lodoso de suas almas" (1950, fl.56). Ao confrontar Angélica no intuito de retirar Lídia daquela casa, Leôncio ouve da protagonista: "Você não me engana: queria apenas devorá-la antes de mim", ao que ele rebate: "Sua linguagem me dá arrepios" (fl.60). A relação entre Angélica e Leôncio guarda extraordinária semelhança com a ligação entre Aurélia e Miguel, de $O$ desconhecido, no que o criado funciona como cúmplice da senhora criminosa. No caso de Leôncio, há, entretanto, o arrependimento e o confronto, o que não ocorre entre Aurélia e Miguel. Porém, o dado da senhora aristocrática ver o criado como objeto erótico é recorrente em Lúcio Cardoso. Aurélia é amante de Miguel e tenta seduzir José Roberto, do mesmo modo como Angélica tenta, surpreendentemente, seduzir Leôncio:

Posso amá-lo, Leôncio, posso amá-lo como qualquer uma, ou julga que eu sou uma mulher feia? Veja estes braços, estas jóias... Muitos dizem que eu ainda sou moça, que cada dia sou mais moça... Muitos me desejam, seria capaz de apontar na rua os que me olham com cobiça. Veja este rosto, estes olhos que brilham... [...] Passa a mão na minha pele, veja como é sedosa, veja os meus cabelos, sinta o seu perfume! Olhe, são cabelos de mulher, cabelos quentes! (CARDOSO, 1950, fl.63)

Leôncio não apenas se mostra insensível aos arroubos de Angélica como também abandona o sinistro casarão, levando consigo Lídia e Joana. Desesperada, Angélica, "insensível, rompendo violentamente o vestido", arrisca uma última tentativa: "Já experimentou junto à face 
o calor deste sangue? Ah, Leôncio, como você está enganado, como se ilude ao me desprezar assim! Sou moça, sou muito mais moça do que outras que andam por aí... Olhe, apalpe esta pele, estes seios, este corpo sem rugas!" (CARDOSO, 1950, fl.65). Ao sair, Joana desafia sua antiga senhora: "Sobre quem se lançará sua natureza criminosa de agora em diante? Quem sugará, quem matará aos poucos, quem Ihe fornecerá o alento da sua eterna juventude?" (fl.67). Ao partirem todos, o rosto de Angélica subitamente envelhece: "Oh, não quero mais me ver, detesto este rosto formado pelos restos de tantas pessoas mortas!" (fl.68), diz, atirando um objeto ao espelho, que se parte em pedaços. Com um revólver, Angélica se suicida. Agonizante, arrasta-se no chão e, tomando um caco do espelho nas mãos, interroga a sua própria imagem refletida:

Lá está ela, não disse? Lá está a outra, a que me espia com os olhos brancos, sem nada compreender. Não quero que ela me olhe assim, proíbo-a que faça isto! Ah, lá continua ela... Que me quer você, que espera de mim? Quem lhe deu o direito de se instalar aí e vigiar todos os meus atos? Porque me persegue deste modo, qual é o seu nome, quem é você? Vamos, diga, quem é você, quem é? (CARDOSO, 1950, fls.68-69)

Ao exalar seu último suspiro, Angélica, porém, pergunta-se: “Mas ao certo, quem sou eu, meu Deus, quem sou eu?" (1950, fl.69). Nesta peça de Lúcio Cardoso, as vítimas vampirizadas não correspondem a objetos de desejo erótico, mas sim a fontes de perpetuação da juventude para que o erotismo do vampiro possa acontecer livremente. Há vampiros que não sugam sangue de suas vítimas, preferindo priválas de coisas igualmente valiosas, como a juventude, por exemplo (RYAN, 1988, p.XVI). O desespero de Angélica no final equivale ao 
desespero de Aurélia, motivado pela exclusão amorosa dos velhos e feios no etos ocidental apolinizado, que só franqueia o acesso a Eros aos que possuem a beleza e a juventude. O vampirismo em Lúcio Cardoso, nas modalidades apresentadas da postura da ave de rapina e da clausura do desejo, vincula-se, assim, a dimensões ontológicas mais amplas, avultando dentro do grande drama da condição humana.

A poeticidade dos textos de Lúcio Cardoso convive com o caráter postiço dos diálogos demasiadamente impostados, soando sobremaneira teatrais, e, em muitos casos, ostentando inclusive o uso de clichês, que logram conferir um caráter kitsch indiscutivel aos textos. "A literatura de Lúcio Cardoso se constrói, acima de tudo, como literatura", apresentando até mesmo "os elementos mais artificiais e antiquados" (BUENO, 2000, p.24). Com efeito, nas narrativas de Lúcio, "eventuais palavras e gestos grandiloqüentes redundam em artificialidade retórica, às vezes francamente camp" (LOPES, 1999, p.111). Este aspecto, porém, embora dissonante com a tradição realista e desliterarizada da narrativa brasileira após o Modernismo de 22 (CANDIDO, 1989, p.205), contribui para o pertencimento de Lúcio Cardoso dentro da tradição da literatura gótica, desde o início marcada por altas doses de artificialismo e teatralização.

\section{REFERÊNCIAS}

ARGEL, Martha; NETO, Humberto Moura (2008). O vampiro antes do Drácula/ organização, comentários e tradução. São Paulo: Aleph.

AUERBACH, Nina (1995). Our vampires, ourselves. Chicago: The University of Chicago Press.

BARROS JUNIOR, Fernando Monteiro de (2002). Vampiros na casa-grande: clausura e poses do Gótico em Lúcio Cardoso. (Tese - Doutorado em Letras Vernáculas). Faculdade de Letras, Universidade Federal do Rio de Janeiro, Rio de Janeiro. 
BARTHES, Roland (1990). Sade, Fourier, Loyola. Mário Laranjeira (Trad.). São Paulo: Brasiliense.

BELSEY, Catherine (1994). Desire: love stories in Western culture. Oxford: Blackwell.

BRANDÃO, Junito de Souza (1988). Mitologia grega: volume II. 2.ed. Petrópolis: Vozes. BUENO, Luís (2000). "A tormenta da existência". Folha de S. Paulo Mais!. São Paulo, 2 de abril, p.24.

CÂNDIDO, Antonio (1989). A educação pela noite \& outros ensaios. 2.ed. São Paulo: Ática, 1989.

CARDOSO, Lúcio (1950). Angélica. (S. I., 69fls. + 126 fls. - cópia). Peça teatral. Arquivo Lúcio Cardoso, Centro de Literatura Brasileira, Fundação Casa de Rui Barbosa, Rio de Janeiro, s.d.

CARDOSO, Lúcio (1969). Três histórias de província: Mão vazias, O desconhecido e A professora Hilda. 2.ed. Rio de Janeiro: Bloch.

CARDOSO, Lúcio (2012). Diários/Lúcio Cardoso; organização, apresentação, cronologia, estabelecimento de textos e notas Ésio Macedo Ribeiro. Rio de Janeiro: Civilização Brasileira.

CARELLI, Mario (1988). Corcel de fogo: vida e obra de Lúcio Cardoso (1912-1968). Júlio Castañon Guimarães (Trad.). Rio de Janeiro: Guanabara.

FRAYLING, Christopher (1992). Vampyres: Lord Byron to Count Dracula. London: Faber and Faber.

GOETHE, Johann Wolfgang von (1999). 103 great poems / 103 meistergedichte: a duallanguage book. StanleyAppelbaum (Trad.). Mineola, New York: Dover Publications. GLADWELL, Adèle Olivia (1999). "The erogenous disease”. In: (Eds.).

Blood \& roses: the vampire in $19^{\text {th }}$ century literature. S.I.: Creation Books.

HINDLE, Maurice (1993). "Introduction”. In: STOKER, Bram. Dracula. London: Penguin Books.

KEMPIS, Tomas de (1948). Imitação de Cristo. Padre Leonel Franca (Trad.). S.J. 4.ed. Rio de Janeiro: José Olympio.

LECOUTEUX, Claude (2005). História dos vampiros: autópsia de um mito. Álvaro Lorencini (Trad.). São Paulo: Editora UNESP. 
LIMA, Luiz Costa (1976). A perversão do trapezista: o romance em Cornélio Penna. Rio de Janeiro: Imago.

LOPES, Denilson (1999). Nós os mortos: melancolia e neo-barroco. Rio de Janeiro: Sette Letras.

MONTEIRO, Maria Conceição (2004). Na aurora da modernidade: a ascensão dos romances gótico e cortês na literatura inglesa. Rio de Janeiro: Caetés.

OTTO, Walter (1995). Dionysus: myth and cult. Robert B. Palmer (Trad.). Bloomington/Indianapolis: Indiana University Press.

PAGLIA, Camille (1992). Personas sexuais: arte e decadência de Nefertite a Emily Dickinson. Marcos Santarrita (Trad.). São Paulo: Companhia das Letras.

PAZ, Octavio (1994). A dupla chama: amor e erotismo. Wladir Dupont (Trad.). São Paulo: Siciliano.

PENNA, Cornélio (1958). Romances completos. Rio de Janeiro: José Aguilar.

PLATÃO (1989). Fedro. Pinharanda Gomes (Trad.). 4.ed. Lisboa: Guimarães.

PRADO, Antonio Arnoni (2006). "Posfácio" In: CARDOSO, Lúcio. Teatro reunido/ Lúcio Cardoso. Curitiba: Ed. UFPR.

PRAZ, Mario (1996). A carne, a morte e o diabo na literatura romântica. Philadelpho Menezes (Trad.). Campinas: Editora da UNICAMP.

RICKELS, Laurence A (1999). The vampire lectures. Minneapolis, MN: University of Minnesota Press.

ROAS, David (2014). A ameaça do fantástico: aproximações teóricas. Julián Fuks (Trad.). São Paulo: Editora Unesp.

RYAN, Alan (1988). "Introduction". In: (Eds.). The Penguin book of vampire stories. New York: Penguin.

SEFFRIN, André (2000). "Demasiadamente humano" (prefácio). In: CARDOSO, Lúcio. Novelas: O desconhecido e Mãos vazias. Rio de Janeiro: Civilização Brasileira. TODOROV, Tzvetan (1975). Introdução à literatura fantástica. Maria Clara Correa Castello (Trad.). São Paulo: Perspectiva.

TWITCHELL, James B (1997). The living dead: a study of the vampire in Romantic literature. Durham, N.C.: Duke University Press. 


\section{"LET THEM DREAM OF LIFE ETERNAL, WE SHALL LIVE IT": GEORGE R. R. MARTIN'S FEVRE DREAM, SLAVERY AND VAMPIRES IN THE UNITED STATES OF AMERICA}

Arthur Maia Baby Gomes (UFRGS)

Claudio Vescia Zanini (UFRGS)

Recebido em 17 mar 2019. Arthur Maia Baby Gomes é mestrando do programa Aprovado em 29 mai 2019. de pós-graduação em Letras pela UFRGS, e atualmente desenvolve dissertação acerca da obra de George R.R. Martin. É bolsista do órgão CNPQ e trabalha com literatura de fantasia e ficção científica. Participa dos grupos de pesquisa Estudos do Gótico (CNPq), GEL (Grupo de Estudos Livres) e GHOST (Gótico, Horror, Onírico, Sobrenatural, Terror), ambos na UFRGS.

Claudio Vescia Zanini é doutor em Literaturas de Língua Inglesa pela Universidade Federal do Rio Grande do Sul (UFRGS). É professor do programa de pós-graduação em Letras da Universidade Federal do Rio Grande do Sul (UFRGS), membro fundador do grupo de pesquisa Estudos do Gótico (CNPq) e coordenador do núcleo de estudos G.H.O.S.T. (Gótico, Horror, Onírico, Sobrenatural, Terror). Suas áreas de interesse incluem o horror ficcional, a literatura gótica, a literatura dramática, e as interfaces entre cinema, literatura e psicanálise.

Resumo: Fevre Dream é um romance de horror histórico publicado por George R.R. Martin em 1982. 
Apesar de ser frequentemente ignorado pelo estudos acadêmicos da obra de Martin, trata-se de um romance importante não apenas porque é nele que o autor definitivamente abraça a darkfantasy, mas também porque nele o vampirismo é usado como instrumento de forte crítica social. Este artigo analisa como o sistema escravagista é descrito em Fevre Dream em associação com memórias de escravidão e o vampirismo, e vem estruturado em quatro seções que enfocam, respectivamente, as memórias de escravidão produzidas nos EUA depois do século XIX; Abner Marsh, o protagonista; a dicotomia entre as forças vampíricas opostas representadas por Joshua York e Damon Julian; e o status dos personagens negros no romance.

Palavras-chave: George R.R. Martin; Fevre Dream; Vampiros; Escravidão.

Abstract: Fevre Dream is a historical horror novel published by George R.R. Martin in 1982. Despite being frequently overlooked by scholarship on Martin's oeuvre, it is an important novel not only because in it the author definitely embraces dark fantasy, but also because it uses vampirism as a tool for strong social criticism. This article describes how the slavery system is depicted in Fevre Dream in association with memories of slavery and vampirism, and it is structured in four sections: slavery memories produced in the United States after the $19^{\text {th }}$ century; Abner Marsh, the protagonist; the dichotomy between the opposite vampiric forces repsented by Joshua York and Damon Julian; and the status of the black characters in the novel.

Keywords: George R.R. Martin; Fevre Dream; Vampires; Slavery. 


\section{INTRODUCTION}

American author George R. R. Martin is internationally recognized for his tour de force A Song of Ice and Fire, which has been the object of comprehensive academic studies for the past decades.While this is beneficial to both his readership/fandom and for academia itself - the complex richness one encounters in A Song of Ice and Fire is not only unquestionable, but also an invitation for reflection and academic discussion - studies pertaining to Martin's work tend to be limited to this particular series. Martin has been a professional writer since 1970 , circulating in genres such as science fiction and horror, and this article intends to increase scholarship on his oeuvre by focusing onFevre Dream, a 1982 historical horror novel set in nineteenth-century United States of America. Scholarly readings of Fevre Dream are not just important because they shed light on the novel itself, but also in the sense that in Fevre Dream Martin embraces dark fantasy, thus laying the groundwork for his magnum opus, particularly its first novel, A Game of Thrones. (HOWE, 2017, p.81)

The context that serves as backbone for the novel is characterized by the presence of slavery as a central theme of public debate and the source of a domestic disagreement, seeing that while Southern states relied heavily on slavery as a work/domination system, the north was the setting of significant industrial growth and did not allow slavery. Broadly speaking, Martin denounces the horrors of the Civil War (1861-1865) and violence in his novel, and in this article we shall describe how the slavery system is depicted in Fevre Dream in association with both memories of slavery and vampirism. 
The plot presents the story of Abner Marsh, a steamboat captain gone bankrupt who receives a proposal to establish a partnership with Joshua York, a rich gentleman of weird habits. Joshua pays for Abner's golden dream, namely, a ship called Fevre Dream that is supposed to be the fastest ship on the Mississipiriver. Despite York's financing, Abner still sees his partnerwith suspicion due to his strange manners and nocturnal habits. The conflict between the two is established when Abner discovers in York's room newspaper clippings about numerous deaths surrounded by mystery. Upon such discovery, York feels compelled to reveal to Marsh that he is a vampire whose objective is to reconcile the race of vampires and humankind throughthe adoption of a potion York had invented that quenches the vampires' thrist for blood without the need of killing humans. York is the bloodmaster, or leader, of a group of vampires who have agreed to give up preying of human beings.

In parallel to the Marsh-York plot, the reader is introduced to Damon Julian, an ancient vampire who is the bloodmaster in a vampire farm, and Billy Tipton, the foreman in Julian's farm. Julian is a predatory sort of vampire whose cruelty becomes blatant from the very beginning of the novel: in his first appearance he orders Billy to buy a slave girl so that he and his friends may feast on her by draining her blood until her death. Despite not having been converted, Billy is as cruel as his master, and his greatestdesire is to become a vampire, which allows the educated vampire-story reader to identify in Julian and Damon a similar dynamic to that between Count Dracula and Renfield in Bram Stoker's 1897 classic vampire novel.

As the plot of Fevre Dream unfolds, Joshua and Julian are presented as two completely opposite vampiric forces - whereas 
the former is diplomatic and tries to spare both humans and vampires, the latter is essentially predatory and evil, and it is the clash between their two visions that enables the plot to unfold.The analysis of the novel presented here is divided into four sections: one focusing on slavery memories produced in the United States after the nineteenth century, another one emphasizing the lead character Abner Marsh, a third section on the dichotomy between Joshua York and Damon Julian, and the last one on the status of the black characters in the novel.

\section{MEMORIES OF SLAVERY}

Before plunging into Martin's novel, it is important to present some relevant aspects in the discussion of the memory of the confederates, as well as the place of slavery in the confederate frame of mind. The American Civil War (1861 - 1865) was, among other things, a war fought because of African slavery in the USA, and "[a]॥l other justifications come down to political differences, reflecting the social and cultural gulf between the free and slave states that might have been bridged if not for the deeply divisive issue of slavery." (DAVIS, 1996, p.xix-xx) As a result, the Southern states, whose workforce in plantations was essentially slave, formed the Confederation and refused to accept the election of Abraham Lincoln, whose agenda wasanti-slavery. That does not necessarily mean Lincoln and his supporters were abolitionists; instead,they intended to prevent slavery from expanding, which would eventually cause its natural end (ÁVILA, 2010, p.64), and that was the main reason for the conflict, which culminated in the Union victory, and the (supposedly) definitive end of slavery. It is 
noteworthy that the association between the horrors of vampirism and those of slavery that Fevre Dream posits is strengthened in the horror mash-up fad from the early 2010s throughAbraham Lincoln: Vampire Hunter (Seth Grahame-Smith, 2010), which depicts Lincoln as a double epitome of the pursuit of freedom.

In the years that followed the south's defeat, there was a gradual building of a pro-confederate memory, which identified the antebellum Southern life with a romantic ideal featuring a society in which hierarchy was respected and that ultimately suffered Norhern intrusion in Southern matters. Those notions made slavery virtually invisible in a context in which Southern slaveholders rejected the rebuilding of the south in the Northern model promoted by the Congress, and that rebuilding included some civil rights to black people.

This ideology, which sees the Civil War as an "aggression" towards the south, is known as The Lost Cause, and is largely present in many cultural manifestations, especially until the 1960s, a time during which the Jim Crow laws were in force. In practical terms, the Jim Crow system was based on segregation, and it determined that "[i]n every aspect of life-eating, sleeping, traveling, learning - black Americans were treated as second-class citizens in a country that had gone to war over their fate." (DAVIS, 1996, p.451) The Lost Cause imagery is characterized by the presentation of the south as an idyllic place, where slaves appear either as loyal to their masters, who always treated them with respect, or as vengeful subversive rebels undeserving of the kindness they had received from their owners. Onscreen fiction has contributed towards the perpetuation of this imagery through movies such as The Birth of a Nation (1915), Gone With the Wind (1939) and Cold Mountain (2003), to mention a few (FERREIRA, 2010). 
The idea of the Civil War as a moment when brothers turned out on each other because of radicalism, thus dragging the nation into dark times, is reinforced by the cultural industry, the building of statues of Southern generals as a form of tribute, homages to the Confederate flag, and its uses as a symbol of support to the Southern cause (ÁVILA, 2010). Even though such manifestations have decreased since the 1960 s, they happen still today and contribute to the building of the Confederate memory, that is, the set of ideas and perceptions in NorthAmerican history that emerged after the Civil War marked by the idealization of the Southern way of life and the depletion of the role of slavery in both the maintenance of such way of life and the beginning of the Civil War.

\section{ABNER MARSH, THE PROTAGONIST}

It is through Abner Marsh's eyes or thoughtthat the reader is introduced to some representations of slavery in Fevre Dream. Firstly, it is important to highlight that Abner occupies a heroic position in the story. The character is built as someone who is morally good within the circumstances, which makes him an overall likable character. In his first conversation with York we see the following dialogue,

"You need my money, Captain," York said. "Why are you telling me this? Aren't you afraid I will find another partner?"

"I don't work that way," Marsh said. "Been on the river thirty years, York. Rafted down to New Orleans when I was just a boy, and worked flatboats and keelboats both before steamers.I been a pilot and a mate and a striker, even a mud clerk. Been everything there is to be in this business, but one thing I never been, and that's a sharper." 
"An honest man" (...) (MARTIN, 2012, p.12)

From the very beginning, Abner Marsh is portrayed as a man of noble character, albeit not necessarily perfect. He is malicious enough to survive in his area of business and to maintain his involvement with slavery-related issues to a bare minimum. This is important, inasmuch as he will later on establish a relationship with black characters that willultimately affect his views onslavery itself. Furthermore, his nobility of character will be enhanced when juxtaposed to thevampiric monstrosity Julian poses.

It is now time to look at Abner's interactions with black characters. After a first appearance of some black waiters whom he completely ignores (MARTIN, 2012, p.2), the Captain thinks about his position regarding the abolitionist movement, with a direct reference to a historical character:

But York's eyes had drained him of his bluster. The man was a fanatic, Marsh decided. He had seen eyes like that before, in madmen and hellraising preachers and once in the face of a man called John Brown, down in Bleeding Kansas. Marsh wanted nothing to do with fanatics, with preachers and abolitionists and temperance people (MARTIN, 2012, p.4)

John Brown was a North American abolitionist who lived between 1800 and 1859. After his first contact with a slave - a boy about his own age who was "'badly clothed, poorly fed...\& beaten.... With Iron Shovels or any other thing that came first to hand"' (DAVIS, 1996, p.131), Brown swore eternal war with Slavery. Years later, he went to Kansas - one of the slavery epicenters in the south - formed a militia that aimed at releasing slaves, and 
he quickly gained the reputation of a ruthless leader capable of murdering if needed. Brown intended to gather the released slaves and form with them a black nation in the Appalachian Mountains of Virginia, and to do so he believed he needed the arsenal held in the small town of Harpers Ferry, Kansas. The break-in led him to hold hostages, and when Brown was surrounded by enemies he did not have the support the thought he would (despite his oratory talents, which Abner Marsh attests to in the previous passage). Eventually Brown was arrested, convicted and executed, and the whole episode became known as Bleeding Kansas. He died in 1859, two years before the Civil War.

The appropriation of John Brown in Martin's novel is a tool to help us understand Abner Marsh's initialviews on slavery. The comparison betweenan abolitionist andreligious fanaticsreinforces in Abner's mind that one should not get involved with abolitionist ideas, particularly if one is a decent man. Despite Abner's early lack of engagement and enthusiasm, he is aware of the hardships black people must endure, and is indeed surrounded by some of them, such as Toby Lanyard, a member of the Fevre Dream's crew who eventually becomes a recurrent character and is introduced to the reader as follows: "The cook was a free colored man named Toby Lanyard, who had been with Marsh fourteen years, ever since Marsh tasted his cooking down in Natchez, bought him and gave him his freedom" (MARTIN, 2012, p.40).

Even though he is acting within the slave logic and does not challenge the system - as opposed to the "radicals" he dislikes - Abner buys a slave only to free him. Of course, the reasons for that may be beyond mere benevolence or even the bending of a 
protagonist's morals before the eyes of the contemporary reader. Although different explanations are possible, Abner's sympathy towards Toby is a textually-supported hypothesis, as the next sections will show.

When the Fevre Dream is in New Orleans, descriptions of slavery intensify. In one of them, the black presence in the city is emphasized, including in the productive sectors. This sort of comment had been absent in the novel up to this point. There are also recurrent descriptions of the brutality slaves are treated with, and when Abner is the one who vocalizes them (in this case, a comparison between slaves and cattle regarding their transportation on ships), we are reminded that Abner is an actor of his own time and context, so his criticism to racism is limited:

"I don't like it none," Marsh complained to Jonathon Jeffer. "It ain't clean. And I tell you, I won't have none of it on the Fevre Dream. Nobody is goin' to stink up my boat with that kind of stuff, you hear?"

Jeffers gave him a worry look of appraisal. "Why, Cap'n, if we don't traffic in slaves, we stand to lose a pile of money. You're sounding like an abolitionist."

"I ain'tno damned abolitionist," Marsh said hotly, "but I mean what I said. If a gentleman wants to bring a slave of two along, servants and such, that's fine. I'll take 'em cabin passage or deck passage, don't matter none to me. But we ain't going to take 'em as freight, all chained up by some goddamned trader." (MARTIN, 2012, p.157)

To the contemporary critical reader, the passage above may pose a contradiction. Right after admitting that people could be transported in the Fevre Dream as slaves, Marsh is accused by 
Jeffers of sounding like an abolitionist. However, this apparent contradictionevidences the limit of the nineteenth-century abolitionism when it comes to racism. Marsh is not accused of being an abolitionist because he said that black people and white people deserved to be treated equally, but only to oppose the extreme violence. A symptom of that is the fact that Abner quickly denies his friend's accusation and resorts to an element from the "lost cause" memory, as if transporting slaves "cabin passage or deck passage" would make the overall situation softer, less violent and dehumanizing. Therefore, he wouldn't be bothered by slaves aboard his ship, provided that they retain a domestic quality.This flagrant moral flaw in the protagonist and the hero of the story is neither irrelevant nor accidental, considering that Marsh's encounter with York - a "sympathetic vampire" (HOWE, 2017) - and his involvement with the vampire plot will alter his perception of human relations, and that naturally includes slavery. Marsh represents the trope of the gray character, which, as Martin himself explains, fascinates him and is recurrent in his oeuvre,

I'm attracted to 'gray' characters, characters who are not what they seem, characters who change. I think that's the most interesting part of fiction, and a lot of fantasy doesn't have that. Too many characters are black and white, and everybody's fighting a Dark Lord. I just wasn't interested in writing that kind of thing. Having multiple viewpoints is crucial to the grayness of the characters. You have to be able to see the struggle from both sides because real human beings in a war have all these processes of self-justification, telling ourselves why what we're doing is the right thing. Nobody except in a cartoon says, 'I'm the 
Dark Lord, and now I'm going out to do Evil Things.' We are the Gray Lords! And of course, you see that in real-world struggles throughout history. George Bush thinks he's right, Osama bin Laden thinks he's right, and they each think the other side is the bad guy. So you need a multiplicity of viewpoints to present any conflict that's going to be more than a cartoon one.(MARTIN, 2005)

Marsh's racism serves a purpose here, namely, to make the reader question his morals and qualities. Thus, slavery becomes more of a social disease capable of affecting even the most decent and likable characters, which would make themgray, rather than black or white. This argument will be revisited in the following section, in the discussion of the differences between the vampires, Joshua York and Damon Julian.

Despite the efforts to make Abner Marsh a man of his own time, the novel does not corroborate any memory that defames abolitionism or lightensslavery. It becomes clear right after the first half of the book when Abner embraces for once a radical position against slavery. This is important because it is when the character has just gone through a striking experience: his friend/business associate Joshua York revealed himself as a vampire and tells him that humans are called "cattle" by his folk. After that revelation, Abner can tell how it feels like to be seen as inferior and having his humanity taken from him. Immediately after that conversation with York he tells Toby Lanyard:

- You know I never held much with slavery, even if I never done much against it neither. I would of, but those damned abolitionists were such Biblethumpers. Only I been thinkin', and it seems to 
me maybe they was right after all. You can't just go... usin' another kind of people, like they wasn't people at all. Know what I mean? Got to end, sooner or later. Better if it ends peaceful, but it's got to end even if it has to be with fire and blood, you see? Maybe that's what them abolitionists been sayin' all along. You try to be reasonable, that's only right, but if it don't work, you got to be ready. Some things is just wrong. They got to be ended. (MARTIN, 2012, p.239)

Despite being arguably a lot more decent than most of the Southern folk he was surrounded by, Abner Marsh was initially oblivious, narrow-minded and distant regarding a coresocial matter. His previous views were altered after the existence of vampires is brought to his attention; the threat to his existence as a human being provides him with the chance to develop empathy, which becomes clearer in his comment about his participation in the Civil War:

It took away a great deal of blood, Marsh reflected afterward, bitterly. He seldom spoke about the war, or his experiences in it, and had little patience with those who fought the battles over and over again. "There was a war", he would say loudly. "We won. Now, it's done with, and I don't see why we got to yammer about it endlessly like it was something to be proud of. Only good thing come out of it was endin' slavery. The rest I got no use for. (MARTIN, 2012, p.396)

\section{A CLASH OF VAMPIRES: JOSHUA YORK AND DAMON JULIAN}

As far the vampire spectrum is concerned, Joshua York and Damon Julian are diametrically opposed. They both represent interesting vampire tropes - the former is the sympathetic 
vampire, such as Barnabas Collins in Dark Shadows, Louis in Anne Rice's Interview With the Vampireand Edward Cullen in Stephenie Meyer's Twilight, whereas the latter stands for the predatory epitome of evil whose most important example is Count Dracula. Nonetheless, another layer of understanding to this dichotomy is possible, one that transcends literary tropes and that is directly related to different views on racial prejudice: on the one hand, York symbolizes everything the Civil Rights Movement had been trying to achieve - equality, mutual respect and a way to deal with cultural and historical differences; on the other hand, Julian's predatory, blood-thristy vampirism symbolizes the defense of segregation and the notion that one race is superior to another.

Damon Julian is not only a supremacist, but he also doesnot have any concerns with human suffering. The house where he lives in the beginning of the novel used to belong to a slave master who was fooled by Damon; not only does the vampire kill his entire family, but he also reclaims ownership to the property, including the slaves. Julian also allows foreman Billy Tipton to treat the slaves violently, which is graphically represented by a cruel punishment scene of two runaway slaves. In addition, Damon is a supporter of the notion of the "night people" superiority, as vampires call themselves. One of his speeches can be seen as a clear metaphor for the racist ideas of the United States in the context in which the novel's action happens. He says:

"Ah, poor Joshua," He said. He sipped his brandy. "Let the cattle create-life, beauty, what you Will. And we shall take their creations, use them, destroy them if we choose. That is the way of it. We are the masters. Masters do not labor. Let them make 
the suits. We shall wear them. Let them build the steamboats. We shall ride upon them. Let them dream of life eternal. We shall live it, and drink their lives, and savor the blood. We are the lords of this earth, and that's our heritage. Our destiny, if you will, dear Joshua. Exult in your nature, Joshua, do not seek to change it. Those cattle who truly know us envy us. Any of them would be as we are, given the choice." Julian smiled maliciously. "Have you ever wondered why this Jesus Christ of theirs bid his followers to drink his blood if they would live forever?" He chuckled. "They burn to be like us, just as the darkies dream of being white. You see how far they go. To play at being masters, they even enslave their own kind."(MARTIN, 2012, p.247)

The above mentioned quote reveals that Julian is simultaneously cruel and a racist. Both Julian and Marsh reflect upon the racial issues human beings deal with, but while the captain indicates in the beginning that he does not necessarily believe in the supremacy of a given race, Julian rationalizes the whole situation and still considers himself superior, utilizing allegedly legitimate arguments to which he sadly finds social support. This is reinforced by his remarks on the social conflicts caused by slavery: "You see? Even your abolitionists admit the dark races are inferior. They would have no patience with a slave trying to pretend to being white, and they would be disgusted if a white man should drink a potion in order to turn black. (...)" (MARTIN, 2012, p.346).

Once again, there is a comparison between conflicts - humans and vampires, white people and black people, this time from Julian's racist perception. Interestingly, once again the abolitionist movement has its flaws and limits pointed, and Julian's argument 
somehow echoes that of British historian Robin Blackburn. According to him, the majority of the abolitionists were so because of their views about the country's development, but they did not oppose to slavery outside the USA (BLACKBURN, 1988).

A foil to Damon Julian, Joshua York adopts a reconciling attitude by defendingthat humans and vampires may coexist harmoniously, thus suggesting a level of equality between humans and vampires. $\mathrm{He}$ is also a critic of slavery - not only extreme violent acts, but also the mere notion that one human being may be objectified and become another human being's property. This is exemplified by his explanation for his dislike of New Orleans:

"I have a bad feeling, Abner. This city - the heat, the bright colors, the smells, the slaves - it is very alive, this New Orleans, but inside, I think it is rotten with sickness. (...) You wander through the St. Louis and cast your eyes upon all that marble and that delightful dome with the light pouring through it down onto the rotunda, and then you learn it is a famous slave mart where humans are sold like cattle."(MARTIN, 2012, p.158)

Selling slaves is core within the slavery system. People are property, therefore they may be bought or sold. There is no logical way in which Joshua could be against the selling of human beings without criticizing the whole system. Even though he is not an advocate of equal human rights (his reclusion and status as a vampire are hindrances in that sense), he surely displays an abolitionist's mind.York subsequently makes himself more explicit, which enhances his status as a sympathetic vampire and allows Abner Marsh to reconsider his positions. Here are York's words: 
and here in New Orleans I have witnessed the way you enslave your own kind, whip them and sell them like animals simply because of the darkness of their skin. The black people are closer to you, more kin, than ever my kind can be. You can even get children of their women, while no such interbreeding is possible between night and day. (MARTIN, 2012, p.2010)

From the moment he explains his origins and motivations, Joshua York can be seen as an antagonist of the slave system and also of the alleged superiority of the night people in relation to humans. The analogy makes itself each time clearer: those that refuse the enslaving of humanity as a whole will also refuse to enslave a part of it.

\section{BLACK CHARACTERS}

Even though Fevre Dream displays a sophisticated, metaphorical criticism to the slave system, it lacks the perspective of those who are, in the context of the novel, liable to objectification and enslavement. The reader has access to how Abner Marsh, Joshua York and Damon Julian feel about the issue, but there are very few passages that reveal how black characters feel about their condition.

The only recurrent black character is Toby Lanyard, but a few more make shorter appearances: slaves Emily, Sam, and Lily appear as named individuals, while numerous nameless black people represent different collectivities, such as a group of shoremenwho live in the Gray farm. Firstly, let us discuss Emily, Sam, and Lily, for they share many characteristics.

Emily is a slave who appears in the second chapter of the novel, the first one narrated from Billy Tipton's perspective. She is bought 
by Julian's foreman in a public sale and taken to the vampire's farm. This is the first time we see the vampires in action, culminating in the death of Emily, who serves as their prey. Emily is depicted as a scared girl in pain, and she mostly does not react to the things that happen around her, be it when she is being sold, be it at Julian's farm.

Sam and Lily appear in the sixth chapter, the second narrated by Billy Tipton. Both are slaves who had escaped from Julian's farm two years before and who have now been brought back by slave hunters. After they are returned, they witness their captors being murdered by vampires and go back to being captives, probably to be devoured in the following days. They merely disappear, but Emily's destiny is a sufficient hint to what may have happened to them. Therefore, the three slaves are present in only a few scenes and they eventually fall prey to villainous characters who are not only lethal and cruel, but also supporters of the slave system. The three slaves are represented as yielding, fearful and they ultimately fail to survive.

Toby Lanyard's is a different case, though. The cookis bought and freed by Marsh and becomes a recurrent character. Three of Toby's passages deserve an analysis. The first is a dialogue between Marsh and Toby, in which the latter points out the former is talking about abolitionism, and how dangerous that might be.

"You know I never held much with slavery, even if I never done much against it neither. I would of, but those damned abolitionists were such Biblethumpers. Only I been thinkin', and it seems to me maybe they was right after all. You can't just go... usin' another kind of people, like they wasn't people at all. Know what I mean? Got to end, sooner 
or later. Better if it ends peaceful, but it's got to end even if it has to be with fire and blood, you see? Maybe that's what them abolitionists been sayin' all along. You try to be reasonable, that's only right, but if it don't work, you got to be ready. Some things is just wrong. They got to be ended."

Toby was looking at him queerly, still absentmindedly wiping his hands across the front of his apron, back and forth, back and forth. "Cap'n," he said softly, "you istalkin' abolition. This here is slave country, Cap'n. You could git kilt fo' sech talk."

"Maybe I could, Toby, but right is right, that's what | say."

"You done good by ol' Toby, Cap'n Marsh, givin' me my freedom and all so's I could cook fo' you. That you did."(MARTIN, 2012, p.239)

The second chosen passage starts with York and Marsh's decision to take Fevre Dream to Julian's old farm. Toby then feels the need to approach the Captain, considering that the farm was famous among black people for the violent deaths slaves invariably had there. Toby says:

"You done give me my freedom and all, jest fercookin' fer you. But some of them other niggers, the stokers and sech, they won't lissen to Jeb and me here 'bout what a fine man you is. They's scared, and likely to run off. The boy at supper tonight, he heard you and Cap'n York a-talkin' about goin' down to this Cypress place, and now all the niggers istalkin'."

"What?" Marsh said. "You never been down here before, neither of you. What's Cypress Landing to you?" "Nuthin' a-tall," Jeb said. "But some of these other niggers heard of it. There's stories 'bout this place, 
Cap'n. Bad stories. All the niggers run off from that place, cause of things went on there. Terrible things, Cap'n, jest terrible." (MARTIN, 2012, p.162)

Right afterwards Marsh decides to take the situation to Joshua York, who receives Toby and Jeb. The latter says:

They think you's one of them," Jeb put in. "You and you friends, lurin' us down there to the others, like it were. Them stories say those folks there don't come out by day, and you's the same, Cap'n, jest the same. Course, me and Toby knows better, but not them others."(MARTIN, 2012, p.163)

The manipulation of identities is noteworthy here. Both characters are black and free men. Because they are somehow close to the captain, they become spokesmen on behalf of all the black members of the crew. Nonetheless, they distance themselves from their fellow black crew members, for both Toby and Jeb "know better". Such distance is a suggestion of the irrational (and fully justifiable, as the reader knows) character of these people's fears. If neither Jeb nor Toby is really worried about going to Cypress Landing, why bring the matter to the captain's attention?

In the third passage, Abner meets Toby again after many years. During that time, the Fevre Dream was taken by Damon Julian, and while Toby helped Marsh escape, he could not help himself to do so. In this next quote, Marsh is trying to free Toby from Julian and Billy Tipton tries to stop them:

Sour Billy Tipton stopped too, staring. "What the hell you doing up here, nigger?" he snapped.

Toby didn't look at him. He stood there in a frayed brown suit, his hands clasped behind his back, 
head bowed, scuffing one boot nervously against the deck.

"I said, what the hell you doing here, nigger?" Sour Billy said dangerously. "Why ain't you chained up in the kitchen? You gimme an answer now, or you're goin' to be one sorry nigger."

"Chained!" Marsh roared.

At that Toby Lanyard finally raised his head, and nodded. "Mister Billy says I is a slave again, never mind I got no freedom papers. He chains us all up when we ain'tworkin.(MARTIN, 2012, p.352)

At this point the novel presents one of the major problems freedmen have to undergo during slavery times: re-enslavement. Tipton's treatment towards Toby reinforces the systematic violence and constant insecurity that haunted black people at that time, even if they had been freed and had their freedom papers to prove. Despite all hardships, Toby seems to have a happy ending, for after eventually escaping the ship he finds a job and moves north two years before the beginning of the Civil War. Toby is simply not mentioned in the novel after this.

As mentioned previously, black people appear as collectivities in Fevre Dream. The plot unfolds from 1859 to 1870, which means that the final years of the antebellum period are covered, and so are the war years and the official ending of slavery in the USA. The beginning of the novel is predominantly set in Southern states, and the descriptions of places and cities are pervaded by the presence of non-individualized black people who undergo overwhelming violence, as well as physical and verbal abuse.

When Toby and Jeb bring to the captain their concern about going to Cypress Landing, they use the phrase "the black people". 
Every character in this scene has the vision that black people are superstitious, even though Toby and Jeb try to present themselves differently. They think they believe in unreliable monster stories, and that they are letting themselves be led by irrational fear. But if Toby and Jeb claim to "know better", the reader knows even better than the two of them - indeed, they have good reason to be afraid, for all the stories about the farm are true. Consequently, these individuals, who endure terrible social conditions and disbelief about their overall capabilities, are still wiser than more articulate and educated people from supposedly different classes.

This atavistic fear is justified when we analyze the final section of the novel, the one that focuses on the postwar years. The following passage describes Abner Marsh observing freed black men at work in the year 1868 :

He stood with his arms folded against his chest, looking gruff and stern in his severe black coat, and he watched the roustabouts load her up. The rousters were black, every man among them. That was another change. All the roustabouts on the river were blacks now. The immigrants who'd worked as rousters and stokers and deckers before the war were gone, Marsh didn't know where, and the freedmen had taken their places.

As they worked, the rousters sung. Their song was a low, melancholy chant. The night is dark, the day is long, it went. And we are far from home. Weep, my brothers, weep. Marsh knew the chant. There was another verse, one that went, The night is past, the long day done, And we are going home. Shout, my brothers, shout. But they were not singing that verse. (MARTIN, 2012, p.398-399) 
It is clear that even though abolition had occurred a few years before, the destiny awaiting many black people is not social ascension or any form of atonement. They still have tough jobs, live in poor conditions and remain suffering. With the exception of Toby Lanyard (whose ending is open, after all), the black characters in Fevre Dreamare not entitled to a happy ending, just like the majority of the former slaves.

\section{CONCLUSION}

Fevre Dreamdelivers acritique of the notion that slavery was a soft exploration of labor, or that there was any kind of parental relationship between masters and slaves. The subject is treated very emphatically, and the main tool for criticism employed in the novel is the vampire: despite their supernatural characters, Joshua York and Damon Julian represent human stances about slavery, racial bigotry and social prejudice. In doing so, they display their moral character in general. Abner Marsh, the heroic protagonist, undertakes a path of recognizing the harm caused by slavery and ends up changing his attitude towards it - in that sense, Fevre Dream might even be considered a Bildungsroman, and Marsh, the character whose journey we follow and whose psychological changes we witness.

In his novel, Martin employs vampires as a means to deliver a social critique that works both for the distant past, when the story takes place and an institution such as slavery was somehow accepted in social or legal spheres, and the present, when the color of a person's skin sadly is a factor that may determine a lower salary or an increase in one's chance of being incarcerated. Despite being 
supernatural and inhuman in essence, York and Julian become representatives of essentially human reactions.

Even though both perspective and individuality are lacking in the novel, black characters are crucial in Fevre Dream, not only because this is a novel about the American Civil war, but also because the conclusion the novel leads us to is that a black person will invariably suffer by undergoing objectification, either by becoming a slave to a human being, or by becoming a vampire's meal.

Finally, a close reading of Fevre Dream allows us to identify the genesis of one of the many issues George R. R. Martin approaches in A Song of Ice and Fire. When ascending to the power in cities that are held up by the trade of slaves, Daenerys Targaryen ends slavery and frees all captives. Perhaps what Martin wants to tell us through characters such as Abner Marsh, Joshua York, Toby Lanyard and Daenerys Targaryen is that there is something inherently human - even in vampires - that allows us to have some hope for the future.

\section{REFERENCES}

ÁVILA, Arthur Lima de (2010). “O Passado que não é Passado: a Guerra Civil norte-americana (1861-1865) e o mito da Causa Perdida". In: GUAZZELLI, Cesar; FERREIRA, Letícia Schneider; MONTEIRO, Lucas Maximiliano; GONZAGA, Sandro. (Org.). Tio Sam vai à Guerra: os conflitos bélicos dos Estados Unidos através do cinema. Porto Alegre: Letra\& Vida, p.63-73.

BLACKBURN, Robin (1988). The Overthrow of Colonial Slavery: 1776-1848. London: Verso Books.

BROWN. Thomas J. (2006). "Civil War Remembrance as Reconstruction". In: BROWN, Thomas J. (Org.). Reconstructions: new perspectives on the Postbellum United States. Oxford: Oxford University Press, p.206-236. 
DAVIS, Kernneth C. (1996). Don't Know Much About the Civil War: Everything You Need To Know about America's Greatest Conflict but Never Learned. New York: Avon History.

FERREIRA, Letícia Schneider (2010). “O Olhar Cinematográfico Sobre a Guerra de Secessão." In: GUAZZELLI, Cesar; FERREIRA, Letícia Schneider; MONTEIRO, Lucas Maximiliano; GONZAGA, Sandro. (Eds.). Tio Sam vai à Guerra: os conflitos bélicos dos Estados Unidos através do cinema. Porto Alegre: Letra \& Vida, p.74-89.

HOWE, Andrew (2017). "River of Blood: George Martin's Fevre Dream and the Road to Dark Design". Ilha do Desterro, 70(1), 81-90. In https://periodicos. ufsc.br/index.php/desterro/article/view/2175-8026.2017v70n1p81/33488 Access.17.Mar.2019.

MARTIN, George R. R. (2012). Fevre Dream.New York: Bantam Books.

MARTIN. George R. R. (2005). "George R.R. Martin: The Gray Lords". Locus Magazine, Oakland, v. I, November. 


\section{TWO HUNDRED FACES OF A VAMPIRE: LORD RUTHVEN'S INFLUENCE ON VAMPIRE CULTURE}

Francisco Javier Sánchez-Verdejo Pérez (UNED; UCLM; UDIMA) Alexander Meireles da Silva (UFG/Regional Catalão)

Recebido em 10 mar 2019. Francisco Javier Sánchez-Verdejo Pérez es Doctor Aprovado em 29 mai 2019. en Filología Inglesa. Filiación: UNED; UCLM; UDIMA. Niveles de actuación: Profesor de Grado (Grado en Educación Primaria y Grado de Estudios Ingleses) y Profesor de Máster (Máster Universitario en Formación del Profesorado de Educación Secundaria, Bachillerato, FP y Enseñanza de Idiomas).

Alexander Meireles da Silva é Professor Associado da Unidade Acadêmica Especial de Letras e Linguística da UFG/Regional, Professor do Progama de Pós-Graduação em Estudos da Linguagem da UFG/Regional Catalão

Abstract: Being born in the same monstruous night that witnessed the rise of Frankenstein monster, the vampire Lord Ruthven celebrates in 2019 two hundred years influencing vampire culture. As it happens in literature, John William Polidori's creature spread his curse through the centuries creating attractive, aristocrat, sexually ambiguous and immoral male and female vampires. From Victorian penny dreadfuls, novellas and novels such as Varney, the Vampire, Carmilla and Dracula, to present novel as Interview with the Vampire, the short story "The Vampyre" established the character who walk among human 
beings as a predator who chooses his prey. Ruthven was directly shaped on Lord Byron personality and, similar to the famous English poet, was an elegant figure of high culture and refined manners who hid a wild, libertine, profoundly narcissist nature and irascible behaviour, traits that paradoxically became Byron and his literary counterpart delightfully fascinating beings. Reflecting the Romantic esthetic of its time, Polidori's short story instituted the vampire as a rebel beyond bourgeois social norms. Lord Ruthven was an undead and, threrefore, was not bound to the concepts that rule the living ones. In this way, the vampire appeals to humanity hidden desires related to the anguish of death, to the perspective of the transcendence and to the fear of the consequences of this act abandoning human nature. These elements help understanding the cultural impact John William Polidori's creation keep on exercising two hundred years after 1819 through "The Vampyre".

Keywords: Fantastic; Gothic Literature; Vampire.

Resumo: Nascido na mesma noite monstruosa que testemunhou a ascensão do monstro de Frankenstein, o vampiro Lord Ruthven celebra em 2019 duzentos anos de influencia sobre a cultura vampírica. Assim como ocorre na literatura, a criatura de John William Polidori espalhou sua maldição através dos séculos criando vampiros e vampiras atraentes, aristocratas, ambiguos sexualmente e imorais. Dos penny dreadfuls, novelas e romances vitorianos, como Varney, o Vampiro, Carmilla e Drácula, até romances atuais de fins do século vinte como Entrevista com o Vampiro, o conto "O Vampiro" estabeleceu o personagem que anda entre os humanos como um predador que escolhe sua presa. Ruthven foi moldado diretamente a partir do próprio Lord Byron e, como o famoso poeta inglês, era uma elegante figura de grande cultura e educação refinada que escondia uma natureza selvagem, libertina, profundamente narcisista e de comportamento irascível, traços estes 
que paradoxalmente tornavam Byron e seu sósia literário seres deliciosamente fascinantes. Refletindo a estética romântica de seu tempo, o conto de Polidori instituiu o vampiro como um rebelde além das normas sociais burguesas. Lord Ruthven era um morto-vivo e, portanto, não estava limitado pelos conceitos e leis que regem a vida dos vivos. Desta forma, o vampiro apela para desejos ocultos da humanidade relacionada a angústia da morte, da perspectiva da transcendência e do temor das consequências desse ato abandonando sua natureza humana. São estes elementos que ajudam a entender o impacto cultural que a criação de John William Polidori continua a exercer duzentos anos depois de 1819 através de "O Vampiro".

Palavras chave: Fantástico; Literatura Gótica; Vampiro.

The guardians hastened to protect Miss Aubrey; but when they arrived, it was too late. Lord Ruthven had disappeared, and Aubrey's sister had glutted the thirst of a VAMPYRE! (POLIDORI, "The Vampyre").

\section{INTRODUCTION}

In 2019 we celebrate 200 years of one of the germinal works of the vampiric tradition, "The Vampyre; A Tale", by John William Polidori. Like Frankenstein's own monster, the vampire does not die. What underlies is the obsession of our society with vampires. Today, its image has been reflected in everything potentially commercial, radio serials (Orson Welles adapted the novel and played the role of the count in his famous radio dramatization in 1938), books, films, advertisements, ice creams, shirts, animates films; from advertising to cartoons (let us remember Count Draco of Sesame Street), including Anne Rice's best sellers, and even a hit television 
series, Buffy, The Vampire Slayer, and of course, Batman. And the truth is that its popularity works very well in modern society, where Dresser (1990, p.79-119) explains that the vampire has become popular and has even appeared in medicines, kitchen utensils and other everyday tools; in the words of Clive Bloom (1998, p.1): "no fancy dress party would be complete without its 'Dracula'". It is not surprising that in Romania, too, the military resorted to it to ponder the combat strength of their weapons. Proof of this is that the last war helicopter was baptized with the name of "Dracula":

In the last two decades... we have seen the commercial proliferation of new vampire images in a variety of media, from popular novels, to numerous films, to television serials and animated cartoons, to illustrated books for children 'ages four and up'. This multi-media proliferation is designed to appeal to an audience of readers and viewers of more widely diverse ages, levels of literacy, and education, than Stoker could comfortably assume for his novel (ZANGER, 1997, p.18)

The vampire myth can no longer escape the labyrinth in which popular culture has confined it; and it is that in truth this being has always been there, hidden, willing to appropriate a new form, to transform itself in order to safeguard its existence: it is not destroyed or aged by the passage of time; maybe because it lives outside of itself. And for that reason it is an immortal being. Time does not affect it, mutating to adapt to each era. It is, therefore, one of the most modern beings; it has a metamorphic nature and adaptability to the circumstances is what makes it so indestructible; it is willing to change in order to stay. According to David Glover: 
For while the vampire's peculiarly perverse polymorphousness is the source of its resistance to representation, making it notoriously difficult to pin down -throwing no shadow on the floor, leaving no footprints in the dust, casting no reflection in the mirror-its polymorphous perversity is what allows it to proliferate (1999, p.198-199)

Nina Auerbach says that there is one vampire for each time and that: "since vampires are immortal, they are free to change incessantly. Eternally alive, they embody not fear of death, but fear of life: their power and their curse is their undying vitality" (1995, p.5). David J. Skal supports this idea and says: "Ever adaptable, Dracula has been a literary Victorian sex nightmare, a stock figure of theatrical melodrama, a movie icon, a trademark, cuddle toy, swizzle stick, and breakfast cereal" (1990, p.4).

It would take an exhaustive study to find a person who cannot describe the vampire and the myth that inevitably accompanies it, even if that person has never read a single Dracula line. Probably the human being has been the one who has made it immortal by not letting it die and disappear from the imagination. The folklorist and researcher Norine Dresser (American Vampires, 1990, p.47) places it as part of our store of mythical characters.

In view of these considerations, we are not mistaken in stating that the vampire is an immortal, eternal, adaptable, protean myth; a myth that is still alive, as befits its essence. Perhaps its essence demonstrates that both its origin and its influence are more human than it was initially conceived. But what is a vampire? Throughout time they have been monsters, animated bodies, 
attractive women and educated men, but what is it in fact? And, in the literary universe, what is the role of Polidori's vampire on vamapire culture?

\section{THE VAMPIRE: A MYTH THAT GOES BEYOND ITS OWN ORIGINS}

In a generic way, it is clear that myths go beyond their own origins. During the nineteenth century the vampire had become a character more of the romantic aesthetic, a reason for delightful surprises and chills that provided a strange rejoicing. The physician to Lord Byron (1788-1824), John William Polidori (1795-1821), published his account "The Vampyre" in 1819 inspired by his protector (FRAYLING, 1992, p.6) and reflecting the tense relations between Polidori and Lord Byron (FRAYLING, 1992, p.107). The work traces the portrait of an aristocratic, cold, distinguished and rogue vampire: Lord Ruthven. This work was the first model of the modern vampire. "The Vampyre" is considered by many as the first of the stories of this genre. In 1819 Polidori published, almost at the same time as "The Vampyre", his forgotten novel Ernestus Berchtold; or The Modern Oedipus, based on the story he had originally narrated on the night of Diodati. And the fact that the myth has gone beyond its creation is demonstrated by the fact that among all the groups of vampiric beings, namely, elusive beings, decrepit aristocrats, assertive females and young people immersed in postmodern culture... true origin in favour of the more polysemic tradition has been lost.

This tradition has been shaped over the centuries. Thus, one of the most characteristic features, the fangs, has not always been present, contrary to what we think. The first literary vampires did 
not have this element either. The description that Polidori makes of Lord Ruthven in "The Vampyre" does not refer to its teeth at any time; one of the few occasions in which fangs are mentioned takes place in the poem "The Vampyre" $(1810)^{1}$ by John Stagg, in which the diabolical being is caught in the act:

Indignant roll'd his ireful eyes,

That gleam'd with wild horrific stare...

(...)

His jaws cadaverous were besmear'd

With clotted carnage o'er and o'er,

And all his horrid whole appeared

Distent, and fill'd with human gore!

(Apud FRAYLING, 1992, p.105)

Another of the early occasions in which the teeth of a vampire is mentioned is in the first chapter of Varney the Vampyre (1847): "With a plunge he seizes her neck in his fang-like teeth". This is in fact one of the first descriptions in which the teeth appear, attested with the use of the expression "fang-like" when making reference to the teeth, compared to the fact that they are simply called fangs. But we cannot deny that dental hypertrophy, so appreciated by filmmakers, is a trait reminiscent of the werewolf's fangs.

One more characteristic of this vampire is that he dies of a gunshot, therefore this being is affected by firearms.

Speaking of singular contributions of the work of Polidori, we seem to note that the personification of nature, as a wild spirit, subversive and confronting man with his own will, is an inherent characteristic 1 Published in Minstrel of the North. 
of the Gothic novel in general, and the vampiric productions in particular. In Polidori's story, the vampire is resurrected by lunar rays, the latter reflecting, in part, the belief in some areas that the sun's rays could turn the deceased into a vampire.

Nina Auerbach affirms that the vampires before Dracula are spiritual creatures that obtain their vitality - at least part - from the moon, since: "Like the moon, they live cyclically, dying and renewing themselves with ritual, predictable regularity. A corpse quivering for life under the moon's rays is the central image of midcentury vampire literature" (1995, p.25).

Dracula itself renewed his power during the night finding itself trapped during the daylight in its physical form. The nineteenthcentury literature produced a series of vampires that seemed to transcend the physical in favour of the ethereal; it was with the arrival of the cinema when the vampire was defined by its physical form. The route from nocturnal recharge to destruction by means of sunlight came about most notably with Murnau's Nosferatu (1922), where it is suggested that vampires could be destroyed during the day. As the sun rises, Count Orlock simply vanishes and becomes nothing. Since then, the dangers of sunlight remained a consistent feature of the vampire, being adopted in most film and literary productions as a threat to the vampire - if not the primary method of destruction. The Horror of Dracula (1958) presents a dramatic scene where Dracula becomes ashes by the action of the sun's rays. In recent decades the power of the sun has become a prevalent means of destroying vampires in films like Fright Night (1985), Near Dark (1987) and Interview with the Vampire (1994). In fact, both Near Dark and Interview with the Vampire suggest that 
the Star (and fire as an associative element) is the only means of destroying the modern vampire.

Returning to the moon, when it appears in nineteenth-century literature, it does so by evoking the nature under which it appears in the work of authors such as Shakespeare; the moon in this guise distils an enchanted and charming eroticism, attractive, vaporous, it supposes a projection of a human being in a kingdom that is not human, at the same time that it facilitates a blurring of the barriers that separate logic from unreality. The vampire seems to revive under the lunar rays (DIJKSTRA, 1986, p.122).

The star presides over the harmonious vision enjoyed by the vampire, and presides in a manner analogous to how the star presides over the composition "The Rhyme of the Ancient Mariner" (1798) by Samuel Taylor Coleridge (1772-1834). The sailor, like the vampire, searches the moon for a renewal of his existence. The moon seems to unite death with life, it is the connecting link that enables the unreal to become real, causing the reader not to know, therefore, where reality ends and where fantasy, the oneiric begins. The moon becomes, consequently, as happens to Aubrey, in accomplice not only of the vampire, but also of the reader ${ }^{2}$. That is why Victorian readers never got tired of reading and enjoying the association of the moon with the resurrection of the vampire (let us remember that in Varney The Vampyre, the reader who read the serialized novel always found in each of them the resurrection of

2 Unfortunately, it would be Hollywood who, by appropriating literary and folkloric mythology, would pervert the association of the moon, this becoming a symbolism of the werewolf, leaving its association with the vampire as something more anecdotal than effective and real. Only, some productions like the one directed by Lesley Selander in 1945, The Vampire's Ghost, a film with a small budget, tried to revive the connection between these beings and the lunar star (SILVER \& URSINI, 1993, p.91-92). 
at least one of the characters, resurrection of which the moon was witness, accomplice and prelude):

How silently and sweetly the moon's rays fall upon the water, upon the meadows, and upon the woods. The scenery appeared the work of enchantment, some fairy land, waiting the appearance of its inhabitants. No sound met the ear; the very wind was hushed; nothing was there to distract the sense of sight, save the power of reflection (RYMER, 1970, p.362)

And finally, in this work the vampire is associated with the influence of atmospheric conditions, because shortly before the appearance of a vampire a terrible storm arises. In "The Vampyre", we see a possible origin of the association of stormy days with vampiric narrations and productions; in Polidori's story, the fateful night in which Aubrey's beloved dies, it was this atmospheric phenomenon that unleashed itself with all its fury. Also in Varney The Vampyre, or the Feast of Blood (1847) we are presented again a stormy night, full of thunder, continuing thus with a Gothic atmosphere. In Dracula, this fact will be more clearly expressed in the assertions that Van Helsing will make of the vampire powers as well as in the trip to England made by Demeter, whose crew is kidnapped like Persephone (Demeter's daughter), and which will be hit by a terrible storm, an image that was brought to the screen by several filmmakers as far apart as Tod Browning (1931), John Badham in his 1979 film version starring Frank Langella - or Francis Ford Coppola in 1992.

\section{THE ORIGIN OF THE LEGEND}

The prolific production that emerged from the shadow of the vampire reflects the conflict of this being indissolubly joining oral 
folk tradition with literary creation. Consequently, both in "The Vampyre" and in Dracula (1897) there are other components: besides the folkloric, the latter will be influenced by the Polydorian model of the perverse, fatal aristocrat, the penetrating gaze, exquisite manners and irresistible attractiveness for women.

The writer and poet John Polidori (1795-1821) refined the literary essence of the vampire, changing its ghostly appearance to an aristocratic one. Suddenly, the classic myth of the vampire had become intriguing and sexually appealing to readers rather than the horrible being it was. The beginnings of the archetype were placed.

Lord Ruthven, the main character of Polidori, had characteristics that gave him an undoubtedly elegant and attractive appearance. Also lacking were the two most negative characteristics, the thirst for blood and the theory of the living corpse.

"The Vampyre; A Tale" is a work in which the vampire acquires a literary prominence and is commonly accepted as the first story of vampires (the same year of its edition it was translated into German and French). We owe to John William Polidori the first sketch of what will be the classic image of the literary vampire, that of the villainous aristocrat, cold, enigmatic, but, above all, perverse and fascinating for women; in sum. The opposite of what was actually the "little Doctor Polly-Dolly", as Lord Byron maliciously used to call him, the true inspiration for Lord Ruthven. "Polidori's Lord Ruthven was clearly modelled on Byron" (GLADWELLL \& HAVOC, 1992, p.14). This vampire enjoyed his role of amoral parasite, predator and moral destroyer of society in general and of people with whom he came into contact in particular. He enjoyed protecting, 
sheltering and devoting himself completely to destroy the beings he meets; many more qualifiers could be devoted to this being, but we highlight some of the ones suggested by Olivares Merino (2001, p.257): "demonio de la apetencia y concupiscencia material... diablo de la codicia y el vicio, la tentación".

If we reread the words expressed by Polidori regarding Aubrey's desire to travel through Europe, we can establish a clear parallel between the physical journey that Aubrey projects and the fictional (and real) journey that Byron projects and performs: ${ }^{3}$

[It] was time for him to perform the tour, which for many generations has been thought necessary to enable the young to take some rapid steps in the career of vice towards putting themselves upon an equality with the aged, and not allowing them to appear as if fallen from the skies (POLIDORI, 1988, p.9)

On the subject of duality, "The Vampyre" and Wuthering Heights belong to two worlds at the same time. Brontë's work is a diabolical, black novel, but it is also a Victorian, romantic nineteenth-century novel, where the most violent passions and feelings do not seem to oppose conventional morals, but, to the contrary, they submit to them, or they pretend to. The hero of Wuthering Heights is a man of the late eighteenth century, a rebel. Heathcliff, picked up in the streets of Liverpool, comes from nowhere; he has no name. One day he leaves, no one knows to where; he becomes rich and powerful, no one knows how. He is cruel, both with humans and animals, while still having the air of a gentleman. The main character of this work shares with Polidori's Lord Ruthven and with Joseph Sheridan

3 In the same way that Polidori had never visited Greece, which did not prevent him from locating his story "The Vampyre" in that country thanks to the possible stories that he obtained from Byron, we must remember that Stoker had never traveled to Transylvania. 
Le fanu's Carmilla the fact that all three are demonic lovers. The proximity of the abyss fascinates their victims and the possible fall into it greatly increases their fantasies. Fear and pleasure are not only incompatible, but they are often stimulating.

With respect to Lord Byron, this character knew how to embody as no one the archetype of the new beauty, until turning his life into a legend. In his love relationships he sought a perverse voluptuousness in destroying and self-destructing, in transgressing the laws, in experimenting with the senses. He came to affirm that the great objective of life is sensation, to feel that we exist, even through pain. Lord Byron assumes the role of the fatal lover; he was the most famous poet in Europe and the greatest inspirer of the romantic movement of the nineteenth century, becoming over time the symbol of romanticism. Charles Nodier (1780-1844) would say of him that he is the best known of the writers who can be proud to be the promoters of romantic literature; he affirmed that he dedicated himself with great zeal to the representation of the darkest thoughts, to the description of the most repudiated tasks and to narrate the incurable and desperate suffering. Goethe said that Byron was possessed by that demonic attraction that exerts great influence on others. For his part, Gustave Flaubert (1821-1880) would portray him as someone who did not believe in anything but vices.

On what could have happened at Villa Diodati - so named because it belonged to the professor of theology Giovanni Diodati (1576-1649) in the summer of 1816, a mansion located in the vicinity of Geneva curiously visited by Milton before - a lot of literature has been written. What has remained true is that assembled there were George Gordon Noel - third Lord of Byron -, the poet who 
was already surrounded by a trail of diabolical romanticism, the physician Dr. John William Polidori, Mary Shelley, her step-sister Claire Clairmont and Percy Bysshe Shelley. Some films have been made about this group of people and the supposed scandalous nature of the Villa Diodati events as different as Gothic (1986), by Ken Russell, Remando al viento (1988), by Gonzalo Suárez, with Hugh Grant in the role of Lord Byron and Liz Hurley interpreting the role of Claire's, and Haunted Summer (1988), by Ivan Passer.

Due to the humidity and the incessant rain, according to what Mary Shelley herself narrated, they were forced to remain for days on end in the house. In their meetings they dealt with all subjects, especially the literary ones. Apparently they had several books on ghosts, including the mythical Phantasmagoriana, ou Recueil d'Histoires d'Apparitions, de Spectres, Revenants, Fantômes, etc ${ }^{4}$ a German anthology of horror stories published by Jean-BaptisteBenoît Eyriès in 1812 from the first two volumes of a work consisting of five, Gespensterbuch (1811), edited by Friedrich Schulze and Johann Apel. Hence, they ended up challenging themselves to write a ghost story in the shortest possible time. Everyone accepted the challenge. However, only two of them kept their word: Mary Godwin (daughter of the English philosopher William Godwin and the feminist writer Mary Wollstonecraft, later, the poet Percy Bysshe Shelley's wife), when creating the novel Frankenstein, and Polidori with "The Vampyre". After this idea, Shelley was inspired by the recent theories of galvanism that theorized about giving life to an inanimate body. ${ }^{5}$ 4 Published in English in 1813 with the title of Tales of the Dead.

5 Frankenstein was inspired -among others- by the Italian Luigi Galvani's (1737-1798) attempts to reanimate the bodies of dead frogs when stimulated with metal bars. The body manipulations exemplified in both the novel and the film share a similar purpose: improving and taking control of bodies. What is undeniable is the relationship between 
The image of Frankenstein creator was linked to that of the Greek Prometheus who was punished for stealing fire from the gods and the Prometheus of the Latin text, which created a man from mud, fused with the ideas of Rousseau that had such acceptance during that time period. Frankenstein was a modern version of the Prometheus myth, as the subtitle of the work read. ${ }^{6}$ From that night in Geneva, we would also enjoy "The Vampyre", by Polidori, the first complete work on vampires written in English. Decades later, the Irishman Bram Stoker produced a new novel, in which appeared the three witches of Macbeth, the constant anxiety about their masculinity, and the appearance of women hungry for sex.

The short story, "The Vampyre; A Tale", appeared in the April, 1819 edition of The New Monthly Magazine, a work that curiously had been forgotten by its author completely, considering it a minor one. Lord Ruthven, Polidori's vampire, bears an impressive resemblance to Lord Byron (RYAN, 1987, p.xiii-1). At first it was believed that Lord Byron himself had written it, because the editors used an advertising resource that led one to assume he was the author, although the author's name had not been included in the copies.

"The Vampyre" is considered by many as the first of the stories of this genre, because it offers all the basic characteristics of the

the power of electricity and the force of life, a theory that captivated Percy Bysshe Shelley, Mary Wollstonecraft, Lord Byron and the unfortunately forgotten John William Polidori. 6 We must bear in mind the myth of Prometheus and its different variations (Prometheus Pyrphoros, that is, Prometheus as a carrier of fire; Ovidius' Prometheus Plasticator, who modelled a man of clay and gave life by stealing a spark from the chariot of the Sun, Aeschylus' Prometheus Chained, having his liver eaten daily by an eagle, only to be regenerated at night, due to his immortality). In Greek mythology, Prometheus confronted Zeus by creating mortal human beings out of clay. He was usually depicted undergoing punishment for creating and educating humans, and for giving them fire; Aeschylus' play "Prometheus Bound" (c. 5th century B.C.) conveys in its title and text the common image of him being bound and tortured (ZIMAN, 1994). 
monster: immortality, the dominance in its advantage of human weaknesses to lead them to self-destruction, an absolute disdain for everything human, the diabolic fascination about women and men who use it as an element of conquest, survival and destruction. Another novelty of the story we see is that evil is not punished, just as it happens with the Devil, it always escapes as soon as it causes irreparable tragedies, by destroying creatures with a cruelty of the Avernus. Not in vain, the vampire is related to the devil automatically. But there is a peculiarity of this vampire that did not seem to permeate the later representations of this being, and it is none other than the fact that everyone who was favored by the diabolical being ended up destroyed in one way or another; or what is the same, everything that touched was corrupted. Thus, this vampire enjoys destroying, corrupting, in the face of vampires like Nosferatu or Dracula, who enjoy ingesting blood.

By 1846, Lord Ruthven's distinguished and despicable Byronian aura dazzles London and Paris; all kinds of poems, stories and plays that have a vampire as protagonist abound. Fashion even extends to the opera and it is becoming a new commercial formula. Some English moralists begin to worry about the hysteria extending mainly between the youth and the popular classes.

\section{POLIDORI'S LORD RUTHVEN GOES BEYOND PAGES}

The vampire had adopted a new role in 1819 when John William Polidori's work was published. Probably the greatest artistic influence until Dracula, Lord Ruthven would be the inspiration for numerous short stories, plays and operas, all based on the aristocratic vampire that Europe was convinced was Lord Byron. 
The success of Lord Ruthven came not only because of the supreme artistic talent of Polidori, but also, or above all, because of the suggested and scandalous influence projected by Lord Byron.

Polidori's work was accepted with open arms in the Gallic country. The presence of French writers in the vampiric theme counts among its most notable representatives with Pierre Jules Théophile Gautier (18111872), Alexandre Dumas (1802-1870) (whose last play, Le Vampire, premiered in Paris in 1851 after having seen Nodier's theatrical adaptation of Polidori's story), Isidore-Lucien Ducasse (1846-1870), Count of Lautréamont and René Albert Guy de Maupassant (18501893), in addition -evidently - of Charles Baudelaire (1821-1867). With these authors, the genre achieves an evolution and an enrichment difficult to imagine. All of them knew the story of Polidori well and by themselves they had heard or read about those who return from the grave to quench their thirst for blood.

It is with good reason that around 1820, in Paris, and under the influence of the English gothic novel, frantic romanticism became fashionable (remember that a certain style in terms of clothing even became fashionable among the courtiers and bohemians). The same as in London, the vampire floats in the air and that same year the first vampire novel, Lord Ruthven ou les vampires, is published, a two-volume work that was intended to be the continuation of the story of Polidori; its author (although originally it was published anonymously), Cyprien Bérard, taking advantage of the frenzy aroused by the story of Polidori, stretches the argument as much as possible and dedicates his work to Byron. The success is contagious and a few months later three different versions are presented in Parisian theaters 
On June $13^{\text {th }}, 1820$, Le Vampire, melodrame en trois actes avec un prologue, debuted with great acclaim by the audience at the Théâtre de la Porte Saint-Martin in Paris. The play, directed by Charles Nodier in collaboration with T. F. A. Carmouche and Achille de Jouffray, was the first vampiric drama. In this work, the story of Polidori is enriched by a series of elements that come from the opera and the burlesque tone of costumbrist comedies. Although this adaptation did not obtain the endorsement by the critics, the tickets sold out night after night until the point of which some of the musical extracts were sung on the streets of Paris.

Regarding the appearance of the first proof of vampires in Western Europe, in various works by German authors such as Volker Sturm (Von den Vampiren, 1968) and Wilhelm Fischer (Dämonische Mittelwesen, Vampire und Mittelwesen, 1910) we can find abundant evidence of certain written reports and dated in the middle of the fourteenth century in which they narrate the spectral appearances of the undead to sow panic and feed on the blood of the living. One of the most famous operas is Der Vampyr, by Heinrich August Marschner (1795-1861), which achieved enormous success.

Marschner, a multitalented man, studied law and music in his native Zittau and is considered the creator of German romantic opera, where music emerges directly from poetry as an inevitable consequence, according to Hoffmann. He is also well known, standing out in the generation of musicians who developed their work between Weber and Wagner. In his operas, Marschner creates psychologically divided characters, and this melodramatic character has repercussions on music, which can only be fully understood within the context in which the work is developed. Lord Ruthven, 
the protagonist of Der Vampyr is very similar to the character of Don Giovanni in the opera of the same name by W. A. Mozart. Ruthven is a new vampire, who needs the blood of three maidens before midnight of the following day to obtain a pardon that delays the consummation of the eternal curse; his diabolic personality and the elusiveness of his terrible fate create a great melodramatic ambiguity. With a libretto by his stepbrother, W. A. Wohlbruch, based on texts by Polidori and Byron, the opera debuted at the Stadttheater in Leipzig on March 29th 1828 with great acceptance, using the emerging penchant vein of vampiric culture. The style of the German composer and the introduction of supernatural characters create a precedent. It is not that he devises new musical forms, but uses the old ones in a more flexible way, in order to achieve a greater relationship with the meaning of the text.

Therefore, in view of what was said above, it is inferred that the folkloric vampires had been villagers, farmers, but in the eighteenth century the authors were reluctant to turn these beings into the main characters of their stories, so the vampire ascended the social ladder and was placed in the upper classes. Also, few people were interested in reading about dead beings that, besides, had an unpleasant aspect, so the authors decided to adopt a vampire concept more easily recognizable and identifiable with readers: vampires like themselves. A theme present in all vampire stories is social classes. There is more to remember about Lord Ruthven; how his appearance in society is produced by the hand of one of the oldest customs (and that still persists today, albeit in disguise): the parties of society: "His peculiarities caused him to be invited to every house; all wished to see him, and... were pleased at having 
something in their presence capable of engaging their attention" (FRAYLING, 1992, p.108).

Clive Leatherdale, at the beginning of his work Dracula. The Novel and The Legend (1985), confirms and delves into the aforementioned distinction between the vulgar vampire, the folklore vampire and the literary vampire belonging to a respectable social class. The vampire is associated in a general way with the most disadvantaged communities, its social origin is reflected in its appearance and behaviour. The idea of an educated and attractive being dwelling in a castle is the product of the literary imagination.

The use of the aristocratic argument has, consequently, its more evident literary antecedents in Polidori's "The Vampyre". This vision is incardinated within the well-known study pointed out by Ken Gelder (1994, p.34), meaning that Polidori's story seems to suggest that society itself is vampiric, as long as aristocrats feed on the people. This data is not alien to "Carmilla", as it will not be at all to Dracula. Dracula represents the agonizing rural aristocracy in rebellion against the new order. In this sense, the count is the feudal lord who accompanies a cohort of vampires with whom he creates vassalage relationships through blood rites.

\section{THE PROJECTION}

It was John Polidori who set a milestone by writing his story "The Vampyre" in 1819, inspired by Lord Byron. Since then, the vampire was included in the Gothic imaginary, reaching its maximum glory when Dracula appeared in 1897.

Between 1819, when Polidori's evil Ruthven captured the imagination of the public, and 1897, when the most famous vampire 
novel, Stoker's Dracula, was published, vampire novels were very popular. Between these two examples, the stories covered a broad spectrum, such as "La morte amoureuse" by Gautier, published in 1836 and popularly known as "Clarimonde", or Varney the Vampire, the voluminous novel by Scottish civil engineer and writer J. M. Rymer. At first, it was believed that its author was Thomas Preskett Perst (1810-1859) (thesis endorsed by the Reverend Doctor Alphonsus Joseph-Mary Augustus Montague Summers (18801947), the highest English authority on the subject at hand), but later studies point to the fact that it belongs to James Malcolm Rymer $^{7}$ (1814-1881). The reason for this doubt about its authorship could be found in the fact that it was very common that in this type of publications (penny dreadfuls) several authors were involved.

Rymer, who by then was already a writer for several magazines, decided to focus on vampire tales after reading "The Vampyre", a story that had been reprinted in a penny dreadful; Rymer includes many of Polidori's opinions about vampires.

Many important stories have almost always been relegated to the shelves of oblivion until relatively recent times. One of them could be considered as the most important literary influence in the work of Stoker: "Carmilla" (1872).

The figure of the undead, as Bram Stoker would describe it in his masterful production in the death throes of the nineteenth century, is essential to understand the transgression that the Polidorian being supposes (allow us to coin this term), attacking and challenging Nature and the Creator, being eternal, sucking the

7 In any case, what is known is that this author liked to write under pseudonyms, the most popular that he used were those of Malcolm J. Merry and Malcolm J. Errym. 
biblical vital fluid, and postulating as God inasmuch as it harbours the capacity to create life.

"The Vampyre" represents the foundation on which later literary tradition would be built. Lord Ruthven will be the first reference for the subsequent paradigmatic works, presenting a multiform being with an incredible capacity for adaptation, unequivocal proof of his immortality.

Lest we forget that the vampire attributes its origins to the Jungian collective unconscious; in that sense it represents the human desires, dreams and chimeras of transcending this life. Those hopes will become their most horrendous nightmare, a nightmare that has not been separated from the human being, since it inhabits the kingdom of shadows, of darkness, of night. It is of little wonder that for almost 200 years, this figure has acquired an extraordinary variety of appearances.

\section{BIBLIOGRAPHICAL REFERENCES}

AUERBACH, Nina (1995). Our Vampires, Ourselves. London: University of Chicago Press.

BLOOM, Clive (Ed.) (1998). Gothic Horror: A Reader's Guide from Poe to King and Beyond. London: Macmillan.

DRESSER, Norine (1990). American Vampires: Fans, Victims, Practitioners. New York: Vintage Books.

FRAYLING, Christopher (1992). Vampyres: Lord Byron to Count Dracula. London: Faber \& Faber.

GELDER, Ken (1994). Reading the Vampire. London: Routledge.

GLADWELL, Adéle O. \& James HAVOC (Eds.) (1992). Blood and Roses: The Vampire in 19th Century Literature. London: Creation Press.

GLOVER, David (1999). "Travels in Romania-Myths of Origin, Myths of Blood". In: BYRON , Glennis. (Ed.) Dracula. London: Macmillan, p.197-217. 
LEATHERDALE, Clive (1985). Dracula: The Novel and the Legend. Wellingborough, Northamptonshire: Aquarian Press.

OLIVARES MERINO, Julio Ángel (2001). Cenizas del plenilunio alado: pálpitos y vestigios del vampiro en la literatura inglesa anterior a Dracula de Bram Stoker: tradición literaria y folclórica. Jaén: Universidad de Jaén.

POLIDORI, John William (1988). "The Vampyre: a Tale". In: RYAN, Alan (Eds.) The Penguin Book of Vampire Stories. Harmondsworth: Penguin, p.71-137.

RYAN, Alan (Eds.) (1987). Vampires. Two Centuries of Great Vampire Stories. New York: Doubleday \& Co.

RYMER, James Malcolm (1970). Varney the Vampire, or, The Feast of Blood. New York: Arno Press.

SILVER, Alain \& James URSINI (1993). The Vampire Film: From Nosferatu to Bram Stoker's Dracula. New York: Limelight Editions.

ZANGER, Jules (1997). "Metaphor into Metonymy: The Vampire Next Door". In: GORDON, Jon \& HOLLINGER, Veronica (Eds.) Blood Read: The Vampire as Metaphor in Contemporary Culture. Philadelphia: University of Pennsylvania Press.

ZIMAN, J. (1994). Prometheus bound: Science in a dynamic steady state. Cambridge: Cambridge University Press. 


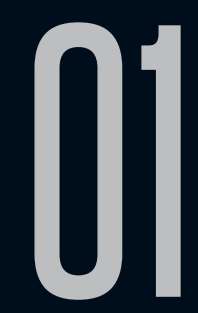

\section{ENTREVISTA COM A ESCRITORA GIULIA MOON}

Alexander Meireles da Silva (UFG-Catalão)

Recebido em 05 mai 2019. Aprovado em 10 jun 2019.
Alexander Meireles da Silva é Doutor em Literatura Comparada pela Universidade Federal do Rio de Janeiro (2008), Mestre em Literaturas de Língua Inglesa pela Universidade do Estado do Rio de Janeiro (2003), Especialista em Educação a Distância pelo SENAI-RJ (2003), Especialista em Literaturas de Língua Inglesa (2000), Bacharel e Licenciado em Língua Inglesa e Literaturas Correspondentes (1998) pela Universidade do Estado do Rio de Janeiro. Desde 2009 atua como Professor Associado de Língua Inglesa e Literaturas de Língua Inglesa da Unidade Acadêmica Especial de Letras e Linguística da Universidade Federal de Goiás - Regional Catalão, onde também é Professor permanente do Programa de Pós-Graduação em Estudos da Linguagem da RC/UFG. É membro fundador dos Grupos de Pesquisa Estudos do Gótico (CNPq) e Nós do Insólito: Vertentes da Ficção, da Teoria e da Crítica (CNPq) que reúnem pesquisadores e pesquisadoras de diversas universidades do Brasil. Suas pesquisas se concentram na área Literatura Fantástica. É criador de conteúdo do blog Fantasticursos (www.fantasticursos. com) e do canal do YouTube Fantasticursos (www. youtube.com/fantasticursos), onde oferece conteúdo, cursos e consultoria sobre o Fantástico na Literatura e no Cinema nas vertentes da Fantasia, Gótico, Horror e Ficção Científica. 


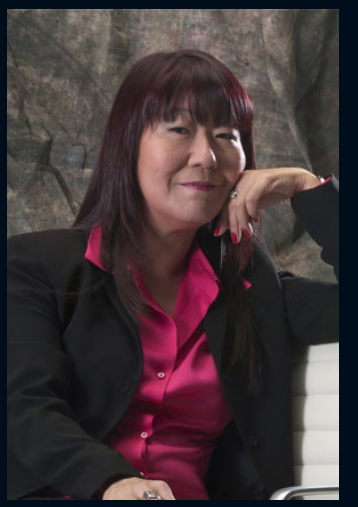

Refletindo o impacto da internet sobre o surgimento e disseminação de escritores e escritoras da Literatura Fantástica brasileira no século XXI, a ilustradora e publicitária Giulia Moon estreou como escritora nos grupos virtuais usando o pseudônimo criado pela própria autora. Condizente com suas temáticas vampirescas, Giulia é admiradora do fascínio e mistério exercido pela lua (para ela, os dois "o"s da palavra "moon" dão a impressão de dois olhos abertos em espanto). A partir do feedback recebido do público leitor sobre as histórias de vampiros que ela publicava nos fóruns de literatura, Giulia Moon primeiro estabeleceu sua base de leitores e leitoras e logo seus escritos começaram a aparecer em coletâneas e livros. Ela é autora da série Kaori, protagonizada pela vampira japonesa Kaori e que já conta com três volumes publicados: Kaori: Perfume de Vampira (Giz Editorial, 2009), Kaori 2: Coração de Vampira (Giz Editorial, 2011) e Kaori e o Samurai Sem Braço (2012). Giulia Moon já participou de diversas coletâneas de contos, sendo as mais recentes As Vampiras: Flores Mortais (Giz Editorial, 2014), com treze contos da autora cobrindo sua produção do ano 2000 até 2014 e Histórias Felinas (SESI-SP, 2016) em parceria com Helena Gomes. Como a principal voz feminina da Literatura de Vampiros no Brasil, Moon possui fãs que comparecem em eventos literários vestidos como seus personagens e a chamam de "titia Giu". Além de ministrar oficinas literárias e participar de projetos como o intitulado Fantásticas, a escritora pode ser encontrada nas redes sociais conversando sobre vampiros, animes, gatos e rock japonês. O site oficial dela é www.giuliamoon.com.br

Na entrevista abaixo, Giulia Moon fala sobre os desafios de se trabalhar com a tradição do vampiro, os desafios de se trabalhar com o personagem no contexto do século vinte e um e outros temas. 
P.: Olá Giulia! Primeiramente agradeço imensamente em nome da Revista ABUSÕES pela sua disponibilidade para esta edição sobre os 200 anos do conto "O Vampiro" (1819), de John Polidori. Sua presença aqui reitera a meta dos editores em produzir um número de referência sobre os seres da noite. Neste sentido, fale um pouco sobre a escritora Giulia Moon. Onde, quando e como surgiu uma das mais representativas vozes femininas hoje da literatura brasileira no campo dos vampiros?

R.: Muito obrigada pela oportunidade de falar um pouco sobre um tema que adoro: os vampiros. E ainda mais para uma edição histórica. Espero que a nossa conversa, aqui, esteja à altura! Acho que a Giulia escritora esteve comigo desde que nasci, mas só teve liberdade para se mostrar bem mais tarde. Desde pequena, sempre fui uma apaixonada por histórias, quando tinha uns cinco ou seis anos, costumava adormecer imaginando enredos alternativos para os personagens dos livros infantis que minha avó lia em japonês para mim. Depois que aprendi um pouco de japonês, passei a devorar mangás. E como tinha habilidade para o desenho, logo passei a produzir meus próprios mangás. Na época da adolescência, passava quase todo o tempo livre desenhando mangás enormes, com enredos complicadíssimos, que muitas vezes nem chegavam a terminar... Pouca gente sabia dessas minhas "obras-primas", só a família e alguns amigos da escola. Ninguém levava muito a sério esse meu talento, nem eu! Então fui aprender uma profissão. Fiz a faculdade de Publicidade e Propaganda pela FAAP, em São Paulo, e trabalhei como diretora de arte em agências durante vários anos. Até que, em 2000, navegando à toa pela internet, coloquei uma palavra mágica no 
buscador: "vampiros". Eu tinha acabado de devorar vários livros de Anne Rice e estava fascinada pelo tema. Acabei entrando num Yahoo! Groups (lembram-se deles?) chamado Tinta Rubra, de escritores amadores que escreviam contos de vampiros. Foi como se uma porta encantada se abrisse: eu finalmente tinha a oportunidade de contar histórias para um público maior! Passei vários anos no grupo, que chegou a ter cerca de 600 participantes, publicando pelo menos uma vez por semana uma história de vampiros. Pela recepção que obtive, percebi que as minhas histórias poderiam conquistar um público mais amplo. $\mathrm{E}$ foi graças ao incentivo desses amigos do grupo, que lancei o meu primeiro livro em 2003. Chamava-se Luar de Vampiros, e trazia dez contos de vampiros numa edição paga de 500 exemplares. Foi um marco na minha vida. Pela primeira vez eu me sentia uma "escritora". E, pela primeira vez, percebi que queria levar a sério essa profissão. No ano seguinte, a Landy Editora se interessou em publicar meus contos. Por lá saíram mais duas coletâneas: Vampiros no Espelho (2004) e A Dama-Morcega (2006). Senti que estava na hora de me dedicar a um projeto mais ambicioso e, em 2009, lancei o meu primeiro romance: Kaori: Perfume de Vampira, pela Giz Editorial, que teve a coragem de bancar um livro que fugia completamente dos padrões da época. Era uma história de vampiros com uma exótica heroína japonesa, que, longe de ser uma aristocrata, era uma garota de programa que tinha certo gosto por perambular em locais sórdidos. A história era contada em capítulos alternados entre o passado no Japão feudal e o presente numa São Paulo agitada e contemporânea. E, para completar, a autora fazia questão de usar como capa 
apenas um grande ideograma japonês. E o interessante disso tudo é que essa química deu certo. Hoje, dez anos depois, o livro ainda é lido e comentado e Kaori já estreou mais dois títulos: Kaori 2: Coração de Vampira e Kaori e o Samurai Sem Braço.

P.: Considerando a proposta desta edição da ABUSÕES, como você lida com a tradição da literatura de vampiros? É uma referência para se seguir, subverter ou inovar?

R.: A tradição, na minha opinião, é para se conhecer. É importante saber que os vampiros fazem parte do nosso imaginário há muito tempo, ter o conhecimento de que eles, quase como espécimes reais, evoluíram de uma forma primitiva para uma criatura complexa. E que esses seres de dentes afiados desde sempre fascinaram a Humanidade e já eram populares mesmo antes do Drácula se tornar a sua representação mais conhecida. Uma obra muito interessante a abordar esse aspecto é o livro "O vampiro antes de Drácula", de Humberto Moura Filho e Martha Argel. É uma coletânea de contos AD (Antes de Drácula), mas os textos que acompanham cada conto são muito bons e elucidativos. Muitas vezes, as inovações ou as subversões, se realizadas por quem não conhece o tema a fundo, nada mais são do que uma volta a algum ponto da evolução vampiresca, ou se afastam tanto das características do vampiro que acabam se tornando representação de algum outro ser fantástico. Então é preciso, antes de tudo, conhecer. Claro que isso não quer dizer que seja proibido mudar o que é conhecido. Acredito, acima de tudo, na liberdade de criação. Então, que se subverta, que se inove e se recrie... Mas sem perder a essência do vampiro como uma criatura que preda 
pelo sangue, e possui uma similaridade sombria com os seres humanos. Isso é respeitar a sua história e a sua caminhada até os dias de hoje.

P.: A seu ver, qual é a importância do conto de Polidori para o desenvolvimento da imagem dos vampiros como conhecemos hoje?

R.: Adoro toda a mística que existe por trás da criação desse conto - talvez muito mais do que o conto em si. Acho fascinante a ideia de que Frankestein de Mary Shelley e $O$ Vampiro de Polidori nasceram, como embriões, numa mesma noite tempestuosa na Villa Diodati. Quanto ao conto, não há como negar a sua importância histórica, o seu pioneirismo em popularizar pela primeira vez o vampiro como um personagem sutil, bemnascido e envolvente. Com Lorde Ruthven, o vampiro deixou para trás, definitivamente, a criatura suja, feia e malvada vestida com mortalha ou farrapos dos séculos anteriores e tornou-se um aristocrata refinado, sedutor e imoral. As sementes plantadas em $O$ Vampiro floresceriam de forma mais evoluída depois em Drácula, com o vampiro assumindo a sua forma clássica e mais conhecida.

P.: Como a criadora da sensual vampira Kaori vê a representação das vampiras na literatura do gênero?

R.: Durante muito tempo, a imagem do vampiro esteve ligada a devassidão, ao imoral, ao proibido e socialmente inaceitável. E essa carga se torna especialmente pesada se aplicada à imagem da vampira, pois as mulheres desde sempre sofreram com a constante opressão sexual imposta pela sociedade. O público 
acostumou-se a associar a vampira a uma criatura sexualmente agressiva, que se vale de sua condição feminina para levar os homens (ou mulheres) à perdição, tanto que a expressão vamp é utilizada como sinônimo de mulher fatal. Já tivemos vampiras notáveis como Clarimunda de A Morte Amorosa, de Theóphile Gautier, ou Carmilla, de Sheridan Le Fanu, nesse modelo. Mas cada vez mais as vampiras, como personagens, estão evoluindo junto com a própria literatura vampiresca, que sempre se caracterizou por refletir a sociedade do seu tempo. Mirian Blaylock de Fome de Viver, de Whitley Strieber, e Pandora, de Anne Rice, são exemplos da literatura do final do século vinte. Na época que lancei Kaori, dez anos atrás, o livro de vampiros mais popular era Crepúsculo, um romance YA de Stephenie Meyer, e a personagem feminina em voga era Bella Swan, que não era vampira, e sim uma garota humana que almeja unirse com o seu amor - um vampiro apaixonado e politicamente correto. Quando criei Kaori, eu quis mostrar ao público vampiros clássicos, definitivamente ferozes e predadores, sem essa de ser "bonzinho". Kaori é assim, mas é também uma mulher livre: solitária e ferida por acontecimentos do passado, mas que não faz drama de sua condição e vai à luta, seja qual for o obstáculo à sua frente. Kaori se interessa pelos humanos e acha graça nas convenções da sociedade dos homens. Ela vive à margem dessa sociedade, e aceita apenas as regras que Ihe convêm. Por ser uma outsider, ela não precisa se apegar a essa sociedade, como não se apegou a outras pelas quais passou e sobreviveu. Essa perspectiva da passagem de tempo é um ponto de vista bem interessante, que os vampiros - e as 
vampiras - podem nos proporcionar. Quem sabe que espécie de vampira pode surgir nos tempos que vivemos? Eu abordei o tema do protagonismo feminino na minha última coletânea, Flores Mortais, com contos só de vampiras. Embora menos conhecida do que a série Kaori, tenho muito carinho por esse livro, pois fala de mulheres de todos os tipos.

P.: Já em 1897, quando Drácula foi lançado, alguns críticos disseram que não havia lugar para vampiros em meio a uma sociedade industrial como a Inglaterra vitoriana. Dentro deste quadro, quais são os desafios para se escrever sobre estes seres em pleno século vinte e um? Quem é o vampiro hoje?

R.: Vejo os vampiros como criaturas adaptáveis a qualquer ambiente. Como seres inteligentes que são e, graças a sua semelhança com seres humanos, eles transitam em ambientes de qualquer época. Inclusive, acho que hoje, em que o virtual substitui cada vez mais o real, o mundo está especialmente amigável para os vampiros. Se antigamente você podia descobrir um vampiro ao perceber que ele nunca saía à luz do dia, ou não tinha reflexo no espelho, por exemplo, hoje as videochamadas, as compras online, os relacionamentos estabelecidos virtualmente possibilitam ao vampiro fazer qualquer coisa sem sair de sua casa. Talvez até comprar humanos no dark web para o seu jantar delivery.

P.: Como uma das precursoras da literatura de vampiros no Brasil, como você vê o meio hoje em termos de quem escreve? Houve mudanças em relação ao início dos anos 2000? E quais são as tendências? 
R.: Na época, publicar na internet era uma novidade fascinante, e ter um livro impresso em papel era um sonho quase impossível. Se não me engano, havia apenas uma editora que se propunha a publicar livros pagos pelo autor, mas não havia grande demanda, pois não havia muita gente que se propusesse a escrever esse tipo de livros. Os livros de fantasia, ficção científica e terror brasileiros eram restritos ao público infantojuvenil. Se você, adulto, quisesse ler, havia os bestsellers estrangeiros. Então vieram os filmes como Senhor dos Anéis, Harry Potter, e, no caso específico dos vampiros, Crepúsculo, mostrando que existia no país um público ávido pela literatura de entretenimento. A internet abria espaço para que qualquer um, contanto que tivesse um texto na mão, ou no HD, pudesse publicar num blog, num site, num grupo de discussão no Orkut e depois, no Facebook. Houve uma multiplicação de aspirantes a escritor produzindo livros de vampiros - e de editoras que os atendiam com publicações pagas. Publicou-se muita coisa ruim, mas também algumas coisas muito boas. Mas havia o problema da venda desses livros, da distribuição em livrarias, tinha muito autor com a casa abarrotada de livros encalhados. E hoje temos a Amazon, que queiram ou não, resolveu esse problema, possibilitando ao autor chegar ao público mais facilmente e publicar livros virtuais de baixo custo. A tendência, eu acredito, é agora refinar a qualidade do que é produzido. Os autores estão trabalhando de uma forma mais profissional, os leitores estão amadurecendo, se tornando mais exigentes.

P.: Você poderia indicar nomes e obras indispensáveis para conhecer o que é produzido na literatura brasileira em termos 
de obras, autores e autoras, blogs e outras redes que abordam o tema vampiros?

R.: Se você ainda não leu André Vianco, precisa conhecer. Ele é o autor de livros de vampiros de maior sucesso no Brasil, suas obras trazem sempre muita ação e aventura, em ritmo cinematográfico. Comece com Os Sete, o seu primeiro livro.

Um autor bem conhecido nesse meio é Adriano Siqueira. Ele é um pioneiro autodidata que conhece muito sobre vampiros e coleciona milhões de peças sobre o tema. Seus contos de vampiros são curtos e muitas vezes bem engraçados, e têm o encanto ingênuo da simplicidade.

Se você quer conhecer uma ótima personagem feminina vampiresca: Lucila. Precisa ler os dois livros da Martha Argel: Ligações Perigosas e Amores Perigosos. Ah, é dela, também, o excelente livro $O$ Vampiro da Mata Atlântica, que mistura ecologia e vampiros com muito conhecimento de causa!

Se você curte baladas, cultura, história, música e curiosidades vampirescas, não deixe de visitar os domínios do Lord A: a Rede Vamp e a Vox Vampyrica.

E, por último, se quiser conhecer os meus livros, poderá encontrálos pela internet, nos sites das livrarias como Saraiva, Amazon, etc.

P.: O que você poderia nos contar sobre seus novos projetos? O que Giulia Moon vem fazendo?

R.: Nos últimos anos, tive o grande prazer de escrever em parceria com ótimas autoras. Lancei a coletânea Histórias Felinas com Helena Gomes (2016) e o romance juvenil A Gótica que Não Gostava de Fantasmas (2017) com Regina Drummond, ambos 
pela SESI-SP Editora. Está em fase final um livro de terror, escrito a quatro mãos também com Helena Gomes, cujos detalhes ainda não posso divulgar. Fora isso, venho dando oficinas literárias no Fome de Letras, antigo Escrevivendo, desde 2015 em parceria com o escritor Walter Tierno. O nosso Projeto Fantásticas, em que o autor participa do processo completo do nascimento de um livro, escrevendo, discutindo, revisando e acompanhando os bastidores de uma editora, em 2019 já vai para o terceiro volume, e tem recebido muitos elogios pela qualidade dos contos, do design e do acabamento. E tem a saga Kaori, que continua me dando alegrias e conquistando novos leitores a cada dia, cujo terceiro volume eu pretendo escrever em breve. 


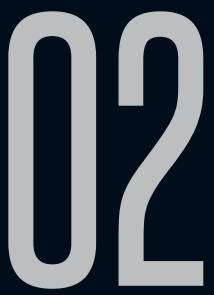

\title{
ENTREVISTA COM O EDITOR CID VALE FERREIRA
}

\author{
Alexander Meireles da Silva (UFG-Catalão) \\ Fernando Monteiro de Barros (UERJ-FFP) \\ Júlio França (UERJ)
}

Recebido em 10 jun 2019. Alexander Meireles da Silva é Doutor em Literatura Aprovado em 11 jul 2019. Comparada pela Universidade Federal do Rio de Janeiro (2008), Mestre em Literaturas de Língua Inglesa pela Universidade do Estado do Rio de Janeiro (2003), Especialista em Educação a Distância pelo SENAI-RJ (2003), Especialista em Literaturas de Língua Inglesa (2000), Bacharel e Licenciado em Língua Inglesa e Literaturas Correspondentes (1998) pela Universidade do Estado do Rio de Janeiro. Desde 2009 atua como Professor Associado de Língua Inglesa e Literaturas de Língua Inglesa da Unidade Acadêmica Especial de Letras e Linguística da Universidade Federal de Goiás - Regional Catalão, onde também é Professor permanente do Programa de Pós-Graduação em Estudos da Linguagem da RC/UFG. É membro fundador dos Grupos de Pesquisa Estudos do Gótico (CNPq) e Nós do Insólito: Vertentes da Ficção, da Teoria e da Crítica (CNPq) que reúnem pesquisadores e pesquisadoras de diversas universidades do Brasil. Suas pesquisas se concentram na área Literatura Fantástica. É criador de conteúdo do blog Fantasticursos (www.fantasticursos.com) e do canal do YouTube Fantasticursos (www.youtube.com/fantasticursos), onde oferece conteúdo, cursos e consultoria sobre o Fantástico na Literatura e no Cinema nas vertentes da Fantasia, Gótico, Horror e Ficção Científica. 
Fernando Monteiro de Barros é Professor Adjunto de Literatura Brasileira na Faculdade de Formação de Professores da UERJ, onde atua no Programa de Pós-Graduação em Letras e Linguística (PPLIN) e desenvolve pesquisa sobre literatura gótica brasileira. É membro pesquisador do grupo (CNPq) Estudos do Gótico.

Júlio França tem Doutorado em Literatura Comparada pela UFF (2006), com Pós-doutorado pela Brown University (2015). É professor de Teoria da Literatura do Instituto de Letras e líder do grupo de pesquisa Estudos do Gótico (CNPq). Criador e administrador, desde 2010, do site Sobre o Medo, dedicado à divulgação de estudos acadêmicos sobre o gênero do horror na literatura. Fundador e coeditor geral do periódico acadêmico Abusões, voltado para a publicação de artigos sobre a literatura fantástica e gótica. Suas publicações mais recentes são As nuances do Gótico: do Setecentos à contemporaneidade (Bonecker, 2017); Poéticas do Mal: a literatura do medo no Brasil (1840-1920) (Bonecker, 2017) e Páginas Perversas: narrativas brasileiras esquecidas (Appris, 2017). E-mail: julfranca@gmail.com 


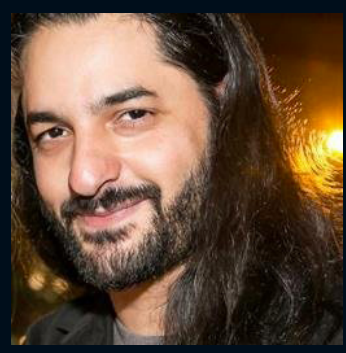

Cid Vale Ferreira é bacharel em Letras pela FFLCHUSP, livreiro e editor. Organizador de Voivode: Estudos sobre os vampiros (2003) e As Trevas e Outros Poemas de Lord Byron (2007). É sócio do Sebo Clepsidra, que tem três livrarias no estado de São Paulo e uma editora independente focada nos imaginários Gótico, Romântico e Decadentista. Idealizou recentemente a Coesão Independente, um grupo horizontal de editoras independentes unidas por ações de apoio mútuo.

P.: Cid Vale Ferreira, a Revista Abusões agradece imensamente por sua disponibilidade para conceder esta entrevista para a edição que celebra os 200 anos do conto "O Vampiro" (1819), de John Polidori. Comecemos, pois, com o tema de nosso dossiê: Qual a importância da narrativa de Polidori para o desenvolvimento da imagem dos vampiros como conhecemos hoje?

R.: Eu que agradeço a oportunidade de participar de uma iniciativa tão necessária ao desenvolvimento dos estudos não apenas do Gótico, mas de toda a literatura fantástica no Brasil. Gostaria de parabenizá-los também pela escolha do tema desta edição. 0 bicentenário da publicação do conto é de extrema importância para o desenvolvimento de um dos ramos mais longevos da tradição gótica: a narrativa centrada na ameaça representada por um vampiro aristocrático.

Podemos nos perguntar, por exemplo, quantas personagens masculinas conhecemos da literatura vampírica anterior a Lord Ruthven, o vampiro de Polidori. Antes, sugiro que não nos detenhamos em discussões sobre monstros hematófagos das mitologias, sobre gules orientais, sobre revenants das baladas macabras, sobre "mortos mastigadores" da Idade Média etc. 
Sugiro focarmos nos vampiros modernos posteriores ao Visum et Repertum e demais documentos que popularizaram a lenda nos moldes consolidados nas primeiras décadas do século XVIII.

Nesse recorte, onde estão os vampiros? No poema de Heinrich Ossenfelder, "Der Vampir" (1748), o vampiro é apenas mencionado pelo eu lírico como algo em que ele gostaria de se tornar, em seu ímpeto vingativo. Na lírica de Goethe, Coleridge e Southey, as personagens Filínion (ou melhor, a versão vampírica inspirada por ela), Christabel e Oneiza são todas femininas. 0 mesmo ocorre no conto "Liebeszauber" (1812), de Ludwig Tieck. Na ópera cômica de Silvestro Palma, I Vampiri (1812), as personagens apenas desconfiam umas das outras, temendo estar rodeadas de vampiros (o que não se confirma).

É verdade que, nas notícias sobre as suspeitas de ataques vampíricos do século XVIII, muitos dos supostos vampiros eram homens, mas eles não haviam sido propriamente "literalizados". Figuravam em notícias de jornal, em perícias médicas, em dicionários filosóficos, em tratados de teologia, mas sempre como figuras históricas sobre quem se comentava, nunca como personagens literárias.

É possível que sejam descobertas personagens vampíricas masculinas em textos anteriores a $O$ Vampiro (alguns estudiosos citam textos alemães perdidos de 1801 e 1812 como candidatos a ocupar essa vaga), mas a criação do primeiro vampiro masculino de relevância internacional em uma narrativa de ficção coube a Polidori. Não bastasse sua importância como marco histórico, Ruthven também é notável como o protótipo 
de uma longa (longuíssima) cadeia de personagens que the devem tributo. Trata-se do vampiro byroniano, resultado da confluência de três pontos: o primeiro é a lenda do vampiro, o segundo é Augustus Darvell, personagem rediviva criada pelo próprio Byron no célebre "concurso" de Diodati, em seu conto inacabado, enquanto o terceiro são traços que podem ser considerados uma caricatura do próprio poeta londrino. Trata-se da mescla de donjuanismo com fatalidade, de beleza física com monstruosidade sobrenatural, e de nobreza social com vileza de caráter. Tudo isso foi apimentado pela atribuição enganosa da autoria do conto a Byron, o que contribuiu para catapultar o vampiro pensado nesse molde como vilão digno da pena de qualquer autor.

Podemos listar alguns exemplos de obras tributárias ao conto. O primeiro romance vampírico europeu foi Lord Ruthven ou Les Vampires (1820), do francês Cyprien Bérard. A peça responsável por popularizar o vampiro no teatro da França foi Le Vampire (1820), colaboração de Charles Nodier, Achille de Jouffroy e Pierre-Frédéric-Adolphe Carmouche com base no conto. Da mesma maneira, a peça que popularizou o vampiro nos palcos britânicos foi The Vampire; or, the Bride of the Isles! (1820), de autoria de James Planché, baseada por sua vez na peça francesa. Na Alemanha, a peça que introduziu o vampiro aos palcos foi outra adaptação do roteiro de Nodier, Jouffroy e Carmouche, intitulada Der Vampir oder die Totenbraut (1821), de Heinrich Ludwig Ritter, que por sua vez serviu de base para a influente ópera Der Vampyr (1828), de Heinrich Marschner. Não por acaso, entre 1828 e 1835, foram publicados na 
Alemanha quatro contos intitulados "Der Vampyr" (por J. E. H. em 1828, por Isidor em 1833, por Hirsch e Wieser em 1835, e, finalmente, por Franz Seraph Chrismar em 1835). Aliás, em um exercício metalinguístico impressionante, o conto de Isidor menciona não apenas a ópera de Marschner e o conto de Polidori (atribuindo-o ainda a Byron), como promove uma intensa reflexão sobre a tradição da narrativa vampírica que começava a ser moldada.

Além desse impacto inicial, personagens como Sir Francis Varney, do penny dreadful Varney, o Vampiro (1845-1847), que, tal como Lord Ruthven, também ressuscita ao ser exposto ao luar, e o próprio Conde Drácula, de Drácula (1897), jamais existiriam da maneira como foram pensados se não fosse pela criação de Polidori.

P.: Como você encara a longa tradição da literatura de vampiros: é uma referência para se seguir, subverter ou inovar?

R.: Essas três maneiras de lidar com ela são igualmente importantes em sua manutenção. Ao seguir e reproduzir o que há de formulaico nessas narrativas, temos a permanência das estruturas que fizeram com que o vampiro moderno se tornasse um fenômeno cultural e quase mítico nos últimos séculos. É o que temos ao observar a publicação de obras como a novela Carmilla (1872), de Sheridan Le Fanu, que retoma elementos do poema de Coleridge, "Christabel" (1816), e da novela anônima alemã traduzida como The Mysterious Stranger (1860) e, mais recentemente, o romance Dracul: A origem de um monstro (2018), de Dacre Stoker e J. D. Barker, que ajudou a reavivar o interesse dos jovens pelo transilvano de Bram Stoker. 
Muitas vezes será necessário subvertê-las para adaptar a tradição aos novos tempos, seja pra introduzir alívios cômicos em meio a solenidade de algumas representações da lenda, como fez Paul Féval com seu La Ville-Vampire (1867), ou para suscitar reflexões mais complexas, como fez Matheson com o clássico Eu Sou a Lenda (1954).

As inovações mantêm a temática pertinente no decorrer das décadas, seja aprimorando a complexidade social das relações entres os mortos-vivos, como Anne Rice propõe nas Crônicas Vampirescas, seja aproximando os vampiros de estéticas mais modernas, como vemos no filme Fome de Viver (1983), cuja ambientação criou uma associação permanente entre a subcultura gótica e os sanguessugas.

P.: Você é o organizador de Voivode; estudos sobre os vampiros (Jundiaí, SP: Pandemonium, 2002), obra seminal sobre o tema no Brasil. Quando os vampiros surgiram na sua vida, a ponto de lhe despertar o interesse por estudá-los, e, depois, publicar um livro de referência sobre o tema?

R.: Muito cedo! Eu tinha quatro anos em 1983 quando, em uma viagem para Belo Horizonte com meus pais e irmãos, ouvimos do meu pai a promessa de que cada um poderia escolher uma HQ na próxima parada se nos comportássemos naquele banco traseiro. Dito e feito!

Peguei um gibi que tinha uma imagem do Spectreman no que eu pensei ser a capa, mas na verdade se tratava de um anúncio na quarta capa de uma edição da Capitão Mistério (Almanaque de Terror 2), com imagens bem gráficas e sangrentas para alguém 
daquela idade. Eu ainda não lia muito bem, mas passei anos e anos com essas histórias gravadas na memória. A primeira trazia um vampiro baseado no Christopher Lee e a segunda, que depois descobri ter sido escrita pelo R. F. Lucchetti, falava de uma condessa vampira que invadia o quarto de seus hóspedes com asas de morcego.

Fiquei tão impressionado que acordei apavorado, e meu pai ficou chocado ao ver do que se tratava realmente a $\mathrm{HQ}$ que comprei. Ele a rasgou em pedaços e, protetor, disse que eu jamais voltaria a ler algo daquele tipo. Deu no que deu.

Daí em diante, os desenhos animados, os filmes, games e livros sobre vampiros passaram a me interessar. Aos treze anos meu quarto parecia um museu de vampiros, com muitos pôsteres, quadros e banners com vampiros do cinema.

Passei a ler sobre eles em livros que me deram a base para começar a pesquisar mais seriamente sobre vampiros na história e na arte. Tempos depois, quando precisei decidir qual seria o tema de um primeiro livro de uma coleção ligada ao meu site da época, o Carcasse.com, acabei escolhendo os vampiros.

Obs.: Cerca de três décadas e meia depois, encontrei outra cópia da tal HQ!

P.: Como alguém que edita e veicula a literatura de vampiros no Brasil, como você, vê o meio hoje em termos de quem escreve? Houve mudanças em relação à época de Voivode, no início dos anos 2000 ?

R.: Em poucos anos após o lançamento do Voivode, já estávamos vivendo em outra realidade. Reunir o que levantamos no livro 
envolveu pequenas aventuras bibliográficas. Vou contar como chegamos a dois desses textos, só para dar uma ideia aos mais jovens de como era a pesquisa na época.

Eu estava escrevendo um texto sobre a presença do vampiro na poesia nacional. Não havia um sistema de busca que varresse toda a internet em busca de palavras-chaves como passamos a ter com o Google.

Fui a um sebo certo dia e abri antologia por antologia de poesia, buscando alguma pista nos sumários. Nada. Passei então a folhear as obras e a fazer uma leitura dinâmica atrás de palavras do campo semântico associado ao vampirismo. Hoje isso seria considerado praticamente loucura.

Em cerca de quatro horas, encontrei apenas uma ocorrência, mas foi uma baita ocorrência: "A Noite" (1799), poema de Silva Alvarenga que trazia o verso "E o Vampir de sangue tinto", considerado a primeira ocorrência do vocábulo em nossa poesia em uma nota de rodapé que também acenava para outra obra, "Octávio e Branca", do Barão de Paranapiacaba, na qual, afirmava a nota, pela primeira vez deixamos de ter "vampiro" significando apenas "morcego hematófago" e passamos a ter a presença do vampiro lendário. Visitei umas cinco bibliotecas com boas seções de obras raras, mas não encontrava o livro A Harpa Gemedora (1849), no qual estaria essa narrativa em versos. Tive de apelar a amigos do Rio de Janeiro, e minha amiga Shirlei Massapust localizou-o na Biblioteca Nacional, onde microfilmamos os trechos correspondentes ao prefácio e ao poema. Isso custava caro, e algumas semanas depois pudemos 
digitar as páginas impressas pela revelação do microfilme. Hoje bastaria baixar o PDF on-line gratuitamente.

Em outro caso, comprei e li o livro Esquecidos por Deus (2000) de Mary Del Priore, atrás de notícias sobre vampiros no Brasil. Lá, havia uma menção aos "abantesmas" mencionados no livro Zoologia Fantástica do Brasil (1934), de Afonso de Taunay. Achei com certa facilidade um exemplar na USP e lá havia uma menção aos vampiros de um grimório português de magia do século XVIII. Novamente, promovemos uma caçada ao livro, e novamente a Shirlei o achou no Rio, no Real Gabinete Português de Leitura, onde transcreveu e digitou o capítulo dedicado aos vampiros no livro Raridades da natureza e da arte (1759), de Pedro Norberto de Aucourt e Padilha. Hoje, igualmente, bastam segundos para baixarmos um PDF dele. É outra realidade!

P.: Como bibliófilo, você indicaria alguma obra da literatura de vampiros ainda desconhecida do grande público e dos estudos acadêmicos sobre o tema?

R.: Muitas das raridades que localizei em minhas pesquisas eu publiquei no Voivode (2003), então não sei se podemos considerá-las desconhecidas, mas creio que mesmo alguns marcos importantes dos países que mais produziram literatura vampírica são pouco lidos por aqui, e acredito que a barreira da língua seja o principal entrave.

Da Alemanha, o já mencionado conto "Liebeszauber" (1812), por exemplo, de Ludwig Tieck, é considerado a primeira obra em prosa a trazer uma vampira como personagem. Muitos dos 
contos derivados da obra de Polidori, como os que eu citei em uma resposta anterior, também jamais foram traduzidos para o português. O primeiro romance vampírico da França, Lord Ruthven ou les Vampires (1820), de Cyprien Bérard, também nunca foi traduzido. Isso, sem citar o influentíssimo drama de Charles Nodier, um dos maiores responsáveis pela difusão do protótipo de Polidori pela Europa.

Da Inglaterra, há alguns contos que são ouro puro. A primeira narrativa vampírica escrita por uma mulher, "The Skeleton Count, or The Vampire Mistress" (1828), de Elizabeth Caroline Grey, por exemplo, mescla vampirismo com reanimações de cadáveres à Frankenstein e maldições como a que transforma o personagem-título em um esqueleto animado todas as noites. É divertidíssimo! Isso, sem falar no rei dos penny dreadfuls, o espetacular Varney, o Vampiro, do qual muito se fala, mas pouco se lê.

No Brasil, eu destacaria que as metáforas vampíricas dos poemas de Zoroastro Pamplona têm um quê baudelaireano bastante sombrio, e ainda não me conformo de não haver dezenas de estudos sobre a produção do nosso decano R. F. Lucchetti (que criou inúmeros vampiros em suas centenas de obras).

P.: Você está à frente da edição da primeira tradução brasileira do Varney, the Vampyre. Conte-nos um pouco sobre como surgiu a ideia de publicar a obra?

R.: Quando eu estava escrevendo e organizando o Voivode, meu grande amigo Carlos Primati (um dos coautores e editor da obra) tinha uma editora que até então só existia no papel. 
Resolvemos inaugurar o catálogo dela com nosso livro e ele me convidou para criar um plano de publicações.

No nosso primeiro brainstorm, já havíamos decidido traduzir o romance. Montamos uma equipe com três tradutores (nós e o editor Ricardo Giassetti) e começamos a nos revezar nas traduções de cada capítulo em 2002. Não avançamos muito, e não nos culpo. A empreitada é longa e árdua (são mais de 200 capítulos em inglês de meados do século XIX).

Com a abertura da editora Sebo Clepsidra, em 2018, recuperei os planos que havia feito para a Pandemonium (editora do Primati) e logo reativei vários projetos antigos, incluindo esse. Quase desistimos logo no início, pois nossas parceiras da editora Wish haviam anunciado seu lançamento, mas o anúncio de que elas não lançariam mais a obra nos motivou a retomar o nosso. Para mim, conhecer a obra é conhecer algo único. Vemos ali a gênese de inúmeras soluções que se tornariam clichês nas narrativas vampíricas, e os autores (dos quais é certo que James Malcolm Rymer era o principal) tinham de pensar o impensável para manter o ritmo frenético da ação. Trata-se de uma leitura surpreendente! Mesmo que dê muito trabalho, mesmo que não dê retorno financeiro, creio que estarei muito feliz por oferecer algo dessa magnitude ao público brasileiro.

P.: O que você poderia nos contar sobre seus mais recentes projetos editoriais?

R.: Tenho muito interesse em ampliar o número de coleções da editora. Sou fã e colecionador de séries como a Trevo Negro e a Livro B. Minha meta é que uns $80 \%$ do nosso catálogo em 
breve seja organizado em coleções.

Atualmente, temos as coleções Lord Byron, Imaginário Gótico e Clássicos dos Penny Dreadfuls. Estamos criando uma de livros não literários (iniciada por Mitologia Lovecraftiana, de Caio Bezarias, e Gótico, de Fred Botting, ambas em edições ilustradas), uma sobre narrativas decadentistas (em parceria com a editora Raphus Press), uma sobre byronismo nacional (repleta de obras nunca reeditadas), uma de poemas narrativos (focada em rimances góticos do Brasil e Portugal) e uma de bluebooks góticos inéditos em português. Não estou falando de planos de longo prazo, isso tudo já está em produção.

Estamos moldando nosso modelo de negócio para que os financiamentos coletivos se tornem nossa espinha dorsal, então convidamos todos os interessados em ver esse tipo de obra ganhando edições físicas a nos seguir nas redes sociais e na plataforma Catarse, pois quanto mais apoio tivermos nas divulgações desses projetos, mais rapidamente essas edições ganharão vida.

P.: Cid, agradecemos muito sua gentil atenção e suas respostas tão cheias de preciosas informações para quem pensa em iniciar uma pesquisa sobre vampiros na literatura. Aproveitamos, por fim, para lhe perguntar se você gostaria de dizer algo mais os leitores da Abusões.

R.: Gostaria de deixar nosso contato e nossos perfis nas redes a todos os interessados em nos acompanhar:

Facebook: http://fb.me/seboclepsidra 
Instagram: @seboclepsidra

E-mail: seboclepsidra@gmail.com

Catarse: www.catarse.me/pt/users/22928/

De resto, sugiro sempre que apoiem as publicações independentes. São elas que apostarão no inusitado quando todas as grandes estiverem de costas para tudo que não for o Gótico mais comercial. 


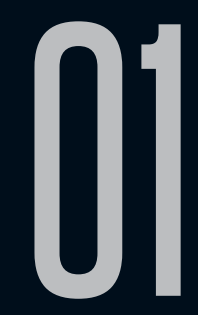

\section{DÉCADENCE FIN DE SIÈCLE (2017), DE MICHEL WINOCK}

Daniel Augusto P. Silva (UERJ/CAPES) ${ }^{1}$

Recebido em 18 mai 2019. Daniel Augusto P. Silva é Doutorando em Teoria da Aprovado em 28 jun 2019. Literatura e Literatura Comparada na Universidade do Estado do Rio de Janeiro e bolsista CAPES sob orientação do Prof. Dr. Julio França (UERJ). Além disso, integra o Grupo de Pesquisa Estudos do Gótico (CNPq). É coorganizador do livro Páginas Perversas: narrativas brasileiras esquecidas (Appris, 2017).

10 presente trabalho foi realizado com apoio da Coordenação de Aperfeiçoamento de Pessoal de Nível Superior - Brasil (CAPES) - Código de Financiamento 001. 
O historiador Michel Winock é autor de uma obra acadêmica bastante diversificada, reconhecida e premiada. Além de ter estudado tópicos do desenvolvimento político francês e de ter produzido biografias sobre Gustave Flaubert e Madame de Staël, ele se tornou particularmente conhecido pelo livro O Século dos intelectuais [1997], em que se dedica a analisar a atuação

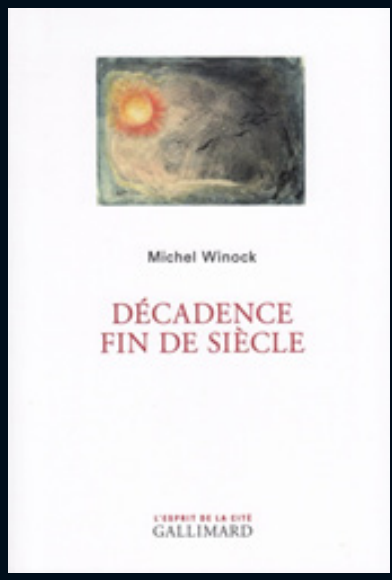
de intelectuais franceses, como André Gide e Jean-Paul Sartre, no século XX. Recentemente, em outubro de 2017, o acadêmico publicou, pela editora Gallimard, o volume Décadence Fin de Siècle, ainda sem tradução para o português. Na obra, ele analisa a produção artística e as ideias culturais, políticas e sociais das últimas décadas do século XIX. Trata-se não apenas de um período fértil para a literatura francesa, mas também de interesse para os pesquisadores do insólito ficcional, pois é quando surge a prosa de ficção decadente, caracterizada por uma abordagem negativa, pessimista e, em geral, não mimética da realidade. Dividido em dezessete capítulos, o trabalho apresenta elementos do imaginário de escritores como Léon Bloy, Joris-Karl Huysmans, Joséphin Péladan, Rachilde, Maurice Barrès, Barbey d’Aurevilly, e temas variados, como a decadência, o satanismo, o ocultismo, a androginia, a morbidez, o anarquismo e o nacionalismo.

No prefácio do volume, Winock justifica seu interesse pelos anos finais dos Oitocentos e aponta para a relevância em estudá-los. A primeira razão tem como base a própria trajetória do pesquisador, 
que ainda não havia publicado uma obra especificamente voltada para essa época. Após ter se interessado pela intelectualidade francesa do século $X X$ e por personalidades ativas nos debates políticos entre 1789 e 1885, como Victor Hugo, faltava-lhe um trabalho mais detido sobre as figuras de destaque para a história das ideias entre esses dois recortes temporais. A segunda diz respeito à identificação de uma base comum ao pensamento francês finissecular: a ideia de decadência. Em termos literários, Winock (2017, p.10) destaca a influência de Baudelaire para diversos autores dessa geração, que teriam dado forma à concepção de "uma modernidade mórbida, na qual triunfam a putrefação, a decomposição de uma sociedade infectada de vícios" ${ }^{\prime 2}$. Assim, se busca definir quais foram as causas e as consequências políticas, sociais e artísticas desse sentimento de degeneração apontado por diversos escritores.

O primeiro capítulo do livro, intitulado "República e Decadência", aponta para um aparente paradoxo do final do século XIX: embora seja um período de significativos avanços técnicocientífico e de melhorias na qualidade de vida da população, um sem-número de intelectuais e artistas expressava um sentimento de profunda desilusão e uma impressão de decadência da sociedade. Winock (2017, p.13) indica a possibilidade de interpretar as duas últimas décadas oitocentistas tanto como o triunfo e como o fortalecimento da República, com sucessivas leis sobre liberdade de imprensa, de organização sindical e de divórcio, quanto como o de uma grande depressão social, política e cultural. 
Haveria também argumentos para justificar uma compreensão mais negativa da realidade francesa. Um deles seria a situação demográfica do país, que tinha o menor ritmo de crescimento populacional se comparado a outros países europeus, em especial à Alemanha. Além da baixa taxa de fecundidade dos franceses, a economia passava por um período negativo, com balança comercial deficitária, com aumento nas taxas de desemprego e com dificuldades na produção agrária.

A percepção da decadência da sociedade estaria baseada, sobretudo, em um terceiro aspecto: a progressiva laicização da França. Como aponta Winock (2017, p.16), a instauração da República francesa ocorreu a partir de disputas com a Igreja católica, que se aliava a grupos monarquistas. Com o regime republicano, conventos são fechados, religiosos são expulsos de instituições educacionais e leis pela laicização do ensino são aprovadas. Os novos programas escolares se baseiam em uma separação entre os valores religiosos católicos e os conteúdos científicos e históricos. A essas medidas institucionais alia-se a percepção de que os próprios hábitos culturais haviam passado por uma progressiva distanciação em relação aos dogmas cristãos. Contra esse contexto colocavamse escritores católicos e outros futuramente convertidos, como Barbey d'Aurevilly, León Bloy, Huysmans, Claudel e Bourget. Em momentos diferentes de suas carreiras, eles indicaram a perda de valores religiosos e o materialismo como algumas das causas do estado de degradação social e de pessimismo generalizado.

Se a alma estava doente, afastada dos princípios religiosos, também o corpo sentiria os efeitos da decadência. Uma das principais ameaças à saúde dos franceses do período era o contágio 
pela sífilis, cujos efeitos poderiam deformar severamente o físico dos doentes. Nesse contexto, as práticas sexuais são colocadas sob o exame das ciências e da medicina, que buscavam determinar quais delas seriam as sadias e as potencialmente degradantes. Nas artes, a obsessão com as doenças sexualmente transmissíveis encontraria representação em figuras femininas simultaneamente mórbidas e atraentes, como as femmes fatales (WINOCK, 2017, p.22). Associada ao lento crescimento demográfico, aos problemas econômicos, à laicização do sistema educacional do país, à degradação física da população e à expansão do sistema democrático, a decadência se tornou uma noção abrangente e bastante útil para caracterizar a visão de mundo desencantada de parte significativa da intelectualidade do período:

Decadência? Melhor seria, na verdade, empregar o plural, de tanto que a decadência carrega todos os fantasmas. Ela cobre com seu manto generoso todos os medos de dissolução, de decomposição, de perda de unidade, de colapso de valores. A ideia da igualdade, que subentende também a emancipação da mulher, ameaça explodir a família. Enquanto a obsessão dos maus costumes ocupa o coração do pensamento decadencial: a droga, o adultério, o onanismo, a prostituição, a homossexualidade, a efeminação dos homens e a virilização das mulheres aparecem como sintomas de uma degenerescência física dos franceses (WINOCK, 2017, p.21)

Winock (2017, p.23) indica, brevemente, como o termo "decadente" foi utilizado como alcunha por grupos de escritores que se colocavam contra o naturalismo. Embora tal fenômeno seja verificável em diversas publicações, é preciso destacar o quanto a 
decadência literária e a ficção naturalismo compartilharam temas, técnicas discursivas e recursos narrativos. De todo modo, para exemplificar sua afirmação anterior, o historiador menciona a criação da revista Le Décadent, em 1886, sob a direção do poeta Anatole Baju, que contou com colaborações de autores como Stéphane Mallarmé e Jean Lorrain, entre tantos outros. Nesse tipo de publicação, os autores desenvolveriam um tipo de estilo específico, marcado por termos raros, neologismos e desvios sintáticos, de modo a destacar o caráter artificial, criativo e original de suas produções, distantes do prosaísmo do cotidiano e de parte da literatura popular.

Na parte conclusiva a tais reflexões, Winock $(2017$, p.24) comenta, ainda, que "no final dos anos 1880, o movimento simbolista veio a absorver os adeptos da escola decadente [...]". Nessa afirmação, identificamos duas concepções falhas sobre a decadência literária. A primeira diz respeito à concepção, provavelmente baseada nos estudos de Guy Michaud [1947], segundo a qual a decadência serviria como uma espécie de primeira fase para o desenvolvimento da poesia simbolista, que seria responsável por depurar a arte decadente. A segunda afirmação questionável do autor é sobre a existência de uma "escola decadente". Atualmente, é amplamente defendido pelos estudiosos da literatura fin-de-siècle que não houve uma constituição de um movimento decadente bem definido e com preceitos artísticos amplamente compartilhados e defendidos. Consequentemente, tais estudiosos comentam como as fronteiras eram os chamados "decadentes" e os "simbolistas" eram difíceis de traçar com exatidão.

Nos capítulos subsequentes, o historiador examina ora a produção de romancistas específicos ora alguns temas, tanto 
sociais quanto artísticos, do contexto finissecular e do imaginário decadente. O primeiro escritor apresentado é Léon Bloy (1846-1917), cuja trajetória como obstinado defensor dos princípios católicos é explicitada em detalhes. Embora também mencione o trabalho ficcional do autor, Winock (2017, p.29) enfatiza, em especial, os seus textos jornalísticos, nos quais propagava uma série de críticas contra o anticlericalismo e o materialismo de seus pares. A partir de diversos dados biográficos, o leitor também é informado sobre a atuação dos grupos de intelectuais cristãos frequentados pelo autor, bem como sobre os conflitos gerados por seu comportamento combativo e dogmático. Ao denunciar uma sociedade distante de valores edificantes e marcada pela corrupção moral, parte das narrativas de Bloy compõe o grupo de escritos decadentes da época.

Entre as outras obras decadentes apontadas no volume, À rebours (1884), de Joris-Karl Huysmans (1848-1907), é considerado o lançamento literário mais importante de seu ano de publicação. Após indicar a originalidade do romance e classificá-lo como sem precedentes na literatura francesa, Winock (2017, p.40) qualifica-o como uma espécie de "romance-farol", em virtude de sua repercussão nas letras e de sua centralidade para as reflexões sobre a decadência. Com uma estrutura narrativa quase sem peripécias e com capítulos que podem ser lidos em uma ordem não linear, o livro desenvolve os gostos artísticos excêntricos, as nevroses e o comportamento mórbido de seu protagonista, o aristocrata e esteta Des Esseintes. Ao ressaltar a artificialidade como princípio artístico, em oposição às criações da natureza, e ao se afastar de temas e de personagens prosaicos, o livro indicaria uma nova via ficcional em relação ao naturalismo, ao qual Huysmans se filiara até então. 
Apesar de ter alcançado um significativo número de vendas e elogios da imprensa e de escritores, como Remy de Gourmont e Barbey d'Aurevilly, o romance recebeu críticas negativas em relação ao seu estilo discursivo, considerado extravagante, alambicado e excessivamente artificial. Com efeito, um dos principais traços da literatura fin-de-siècle, tanto na poesia quanto na prosa, foi um uso específico da linguagem, repleta de termos raros, neologismos, inversões sintáticas e de desvios gramaticais. Nesse contexto, a decadência é percebida não apenas a nível narrativo e temático, mas também a nível textual, já que visaria, não raras vezes, ao hermetismo e à obscuridade semântica, o que foi considerado como uma corrupção da língua francesa. De todo modo, tais características exerceram uma influência significativa sobre toda uma geração de escritores, como comenta Winock (2017, p.49): "Para muitos, À rebours havia dado o sinal de uma grande virada literária".

O ano de 1884 teve, ainda, mais uma publicação importante para a constituição da ficção decadente: a edição de Le Vice suprême, de Joséphin Péladan (1858-1918). Com suas obras, o autor seria o representante, por excelência, de um dos aspectos estruturantes da decadência: a exploração do ocultismo. Com o desenvolvimento de personagens descritos como magos, capazes de se comunicar com espíritos e de fazer previsões, Péladan "pretendia alcançar o conhecimento do invisível, do incognoscível, do mistério, do sobrenatural" (WINOCK, 2017, p.65). Frequentemente, nos diálogos empreendidos por tais figuras, surgem críticas ao materialismo, ao cientificismo e ao desprezo à noção de alma. Sob esse ponto de vista, não seria mais possível tratar da humanidade apenas em seus aspectos instintivos e biológicos. Variadas e bastante comentadas nos 
periódicos, as diversas correntes místicas e espiritualistas do final do século XIX também levaram à tematização do satanismo, recorrente na ficção decadente, como atesta, por exemplo, o romance Là-bas (1891), de Huysmans, com suas cenas de missas negras.

Aos cultos satânicos aliava-se, sistematicamente, uma concepção degradante e transgressiva da sexualidade. No quinto capítulo de sua obra, Winock (2017, p.67) busca analisar como a ficção decadente representou as práticas sexuais, que, nos romances, surgiam como uma "obsessão fixada sobre o estranho, o bizarro, o mórbido, o pútrido e o perverso, da impotência de amar ao incesto, do deleite sádico à orgia platônica, da devassidão refinada à guerra dos sexos". Além dos autores já citados anteriormente, tais traços são bastante verificáveis nos romances de Jean Lorrain e de Rachilde, que ainda engendraram personagens andróginos, homossexuais, masoquistas e obcecados com orgias. Na decadência, associa-se ao desejo sexual a percepção de decrepitude física e moral, sobretudo nas figuras das femmes fatales. Vetores de doenças sexualmente transmissíveis, como a sífilis, essas mulheres, simultaneamente atraentes e repulsivas, constituem um dos arquétipos mais comuns da ficção decadente.

Ao tratar de conteúdos macabros e de personagens doentios, a decadência literária explicita a sua atração pelo mal, cujas figurações seriam capazes de impactar e de chocar a recepção. Winock (2017, p.10) defende que essa tendência teria uma de suas mais produtivas fontes na obra de Barbey d'Aurevilly (18081889), cujo "grande tema é o Mal". Embora fosse mais velho que os demais escritores associados à arte decadente, ele teria conseguido exercer grande influência no meio literário, tanto em razão de seus 
livros quanto por sua relação pessoal com autores como Léon Bloy, Joséphin Péladan e Jean Richepin. Sua obra mais célebre e uma das referências intertextuais para a decadência literária, Les Diaboliques (1874) revelava justamente uma poética voltada para o disforme, para personagens monstruosas e para comportamentos transgressivos. Ao publicar o volume, um conjunto de seis narrativas, o escritor foi formalmente acusado de ultrajar a moral pública. Além de compartilhar uma visão artística semelhante a de muitos autores da decadência, ele também era católico e, nesse período, defendia ideias monarquistas. Esse conjunto de características, tanto pessoais quanto estéticas, tornou-o, "nesse fim de século, um dos ícones de resistência à modernidade" (WINOCK, 2017, p.143).

Não apenas as questões religiosas pautavam os debates intelectuais nesse final de século e geravam interpretações negativas sobre o futuro do país. Diversos outros temas, sobretudo os de cunho político e social, acirravam os ânimos na França. Entre eles, destacamse os atentados anarquistas, o desenvolvimento do socialismo e do movimento operário, o fortalecimento do nacionalismo, as tensões antissemitas e as polêmicas sobre a criação da Torre Eiffel para a Exposição universal de 1889. Pelo menos sete capítulos do livro de Winock são dedicados a analisar esses eventos, marcados igualmente pela percepção de decadência. Alguns escritores se engajaram em diversos desses tópicos e também enveredaram pela carreira política. Maurice Barrès (1862-1923), por exemplo, foi eleito deputado e se tornou uma figura de relevo no discurso nacionalista. Já em outro espectro ideológico e com severas críticas ao sistema eleitoral, Octave Mirbeau (1848-1917) se notabilizou por seu apoio aos anarquistas. O descontentamento com o estado de coisas na 
França não apenas impulsionou esses autores à atuação política, como também propiciou que produzissem obras decadentes.

A percepção de decadência seria impulsionada, ainda, por um dos eventos mais marcantes do final do século XIX: o incêndio do Bazar de la Charité, em 4 de maio de 1897, com aproximadamente 120 mortos. No local, acontecia, anualmente, um encontro, em que instituições de caridade, formadas pela alta sociedade católica, vendiam uma série de produtos a fim de arrecadar fundos para doações aos mais pobres. A comoção gerada pelo incidente foi influenciada, em especial, pelo perfil das vítimas, pois, em sua maioria, eram mulheres da aristocracia e da alta burguesia, que professavam a fé católica. As reações à notícia foram exaltadas: muitos teriam encarado a tragédia como um sinal divino de que a França estaria se afastando do bom caminho da religião. Com explicações diversas, mas, majoritariamente, ligadas a uma constatação de debacle coletiva, os jornais também exploraram em detalhes o caso, com dados minuciosos sobre o estado dos cadáveres. Ao comentar a cobertura sensacionalista da imprensa sobre as mortes, Winock (2017, p.257) entende a morbidez como um dos principais aspectos do Zeitgeist finissecular: "Este fim de século é, com efeito, sádico. Sua literatura e sua arte se comprazem nos espetáculos de horror, nas cenas frenéticas, na descrição de perversões raras, no gosto do sacrilégio".

No epílogo de sua obra, o historiador sugere que o sentimento de decadência do final dos Oitocentos se prolongou até o início do século XX. Mesmo com a retomada da economia francesa nos últimos anos da década de 1890, que viria a ser nomeado como o início de uma Belle Époque, o agravamento das ideias nacionalistas 
e do antissemitismo continuariam a promover um sentimento de nostalgia em relação a um suposto passado glorioso, quando tudo era melhor. O desenvolvimento dessas ideias, como sabemos, culminou na Primeira Guerra Mundial. Nesse sentido, parte dos questionamentos do contexto finissecular e o seu intenso pessimismo não se encerram com a mudança de século:

[U]ma mentalidade coletiva - seja ela impulsionada por um meio restrito - é um fato histórico tanto quanto uma guerra ou um golpe de estado. O fim do século XIX, sem dúvidas, banhou-se em um pessimismo sepulcral, cuja dimensão, é verdade, continua imprecisa, por falta de pesquisas de opinião. O tom é dado pelos homens de letras, nos jornais como nos livros; é o tom da época (WINOCK, 2017, p.256)

Ao organizar as ideias de alguns dos principais intelectuais e artistas do final do século XIX, Michel Winock demonstra como esse foi um período bastante produtivo e relevante tanto do ponto de vista do debate de ideias quanto da produção ficcional. Além disso, sua obra tem o mérito de divulgar, em uma linguagem acessível e de forma concisa, os principais aspectos e temáticas da mentalidade fin-de-siècle. O conhecimento do historiador nas minúcias da política e das disputas sociais do período é, ainda, um ponto de destaque do volume, capaz de lançar luzes sobre alguns dos ideais presentes nas obras literárias. Embora não apresente uma abordagem particularmente original em relação às realizações literárias nem grande número de dados inéditos, trata-se de um livro relevante para quem deseja entender como a ideia de decadência estruturou o pensamento do período e deu forma a uma poética específica, com conteúdos, figuras, enredos e estilos discursivos identificáveis. 
Para os pesquisadores das diversas vertentes da ficção insólita, Décadence Fin de Siècle revela uma das literaturas mais pessimistas, desencantadas e mórbidas da ficção ocidental, responsável por desenvolver arquétipos e temas bastante duradouros e influentes em diversas literaturas nacionais.

\section{REFERÊNCIAS}

WINOCK, Michel (2017). Décadence Fin de Siècle. Paris: Gallimard. 


\section{FABUSÕES}

